\title{
A systematic review of the treatment and management of pre- eclampsia and eclampsia in Nigeria
}

Karen Kirk

Population Council

Ishita Chattopadhyay

Follow this and additional works at: https://knowledgecommons.popcouncil.org/departments_sbsr-rh

Part of the Demography, Population, and Ecology Commons, Family, Life Course, and Society Commons, International Public Health Commons, Maternal and Child Health Commons, and the Women's Health Commons How does access to this work benefit you? Let us know!

\section{Recommended Citation}

Kirk, Karen and Ishita Chattopadhyay. 2016. "A systematic review of the treatment and management of pre-eclampsia and eclampsia in Nigeria," Ending Eclampsia Systematic Review. Washington, DC:

Population Council. 


\section{ENDING Eclampsia}

A SYSTEMATIC REVIEW OF THE TREATMENT AND MANAGEMENT OF PRE-ECLAMPSIA AND ECLAMPSIA IN NIGERIA

March 2016 



\section{ENDING Eclampsia}

Ending Eclampsia seeks to expand access to proven, under-utilized interventions and commodities for the prevention, early detection, and treatment of pre-eclampsia and eclampsia and strengthen global partnerships.

\section{POPULATION COUNCIL \\ Ideas. Evidence. Impact.}

The Population Council confronts critical health and development issues-from stopping the spread of HIV to improving reproductive health and ensuring that young people lead full and productive lives. Through biomedical, social science, and public health research in 50 countries, we work with our partners to deliver solutions that lead to more effective policies, programs, and technologies that improve lives around the world. Established in 1952 and headquartered in New York, the Council is a nongovernmental, nonprofit organization governed by an international board of trustees.

Population Council

4301 Connecticut Avenue NW, Suite 280

Washington DC, 20008

Tel: +1. 877.237.9400

www.popcouncil.org

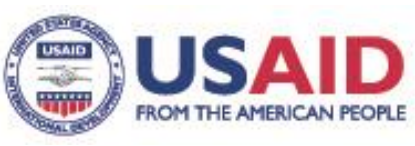

The Ending Eclampsia project is made possible by the generous support of the American people through the United States Agency for International Development (USAID) under the terms of USAID APS-OAA-13-000005. The contents of this report are the sole responsibility of the Ending Eclampsia project and the Population Council and do not necessarily reflect the views of USAID or the United States Government.

Suggested citation: Kirk, Karen R. \& Ishita Chattopadhyay. 2015. "A systematic review of the treatment and management of pre-eclampsia and eclampsia in Nigeria." Washington DC:

Population Council. 


\section{Table of Contents}

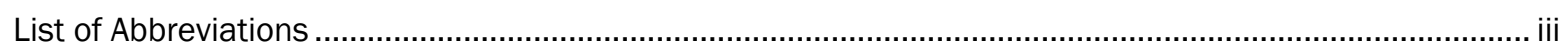

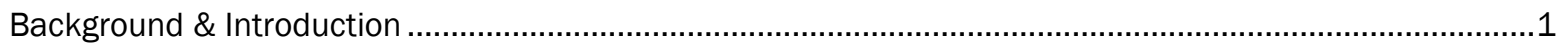

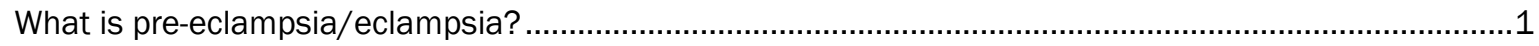

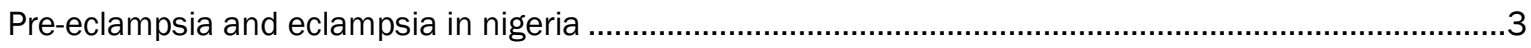

Nigerian health system and maternal health policies ...........................................................................

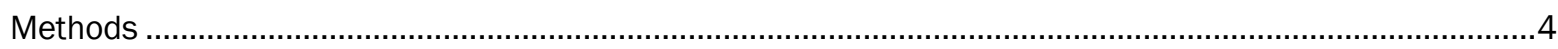

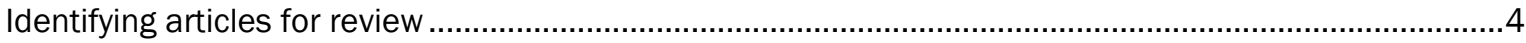

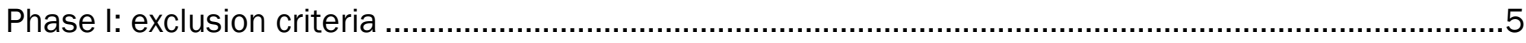

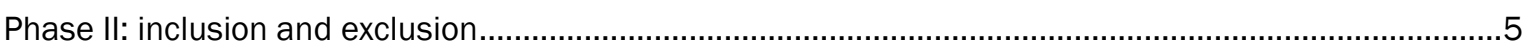

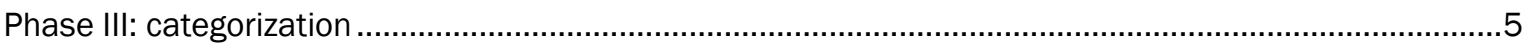

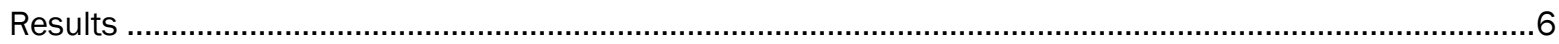

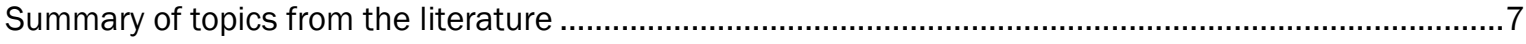

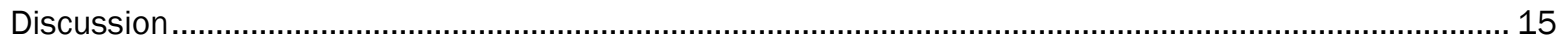

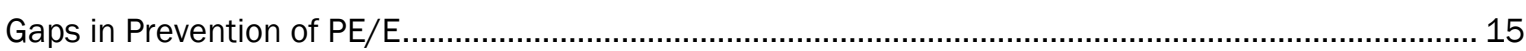

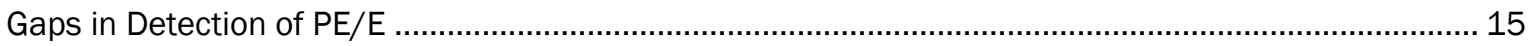

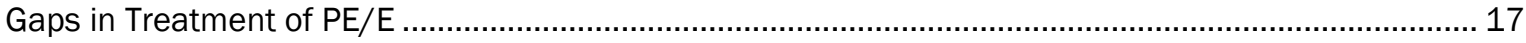

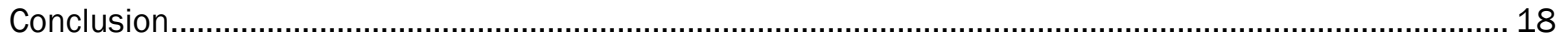

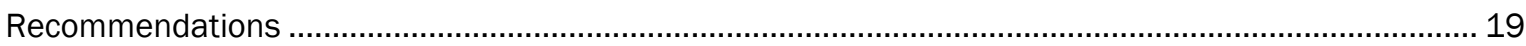

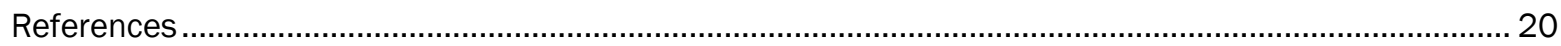

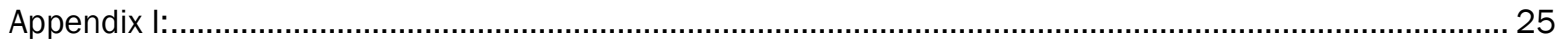

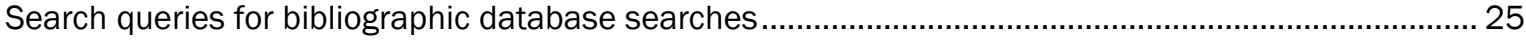

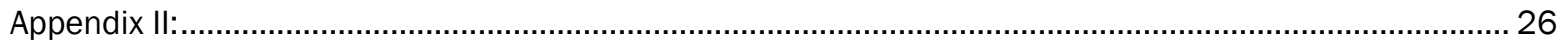

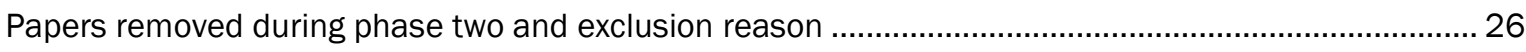

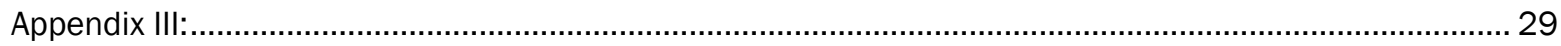

Summary tables OF 19 interventions to improve prevention/treatment of PE/E .................................29

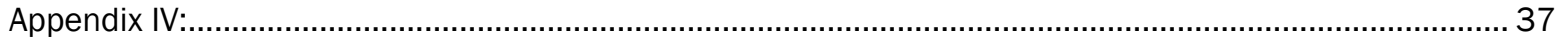

SUMMARY TABLES OF Demonstrated and potential risk factors for PE/E ........................................ 37

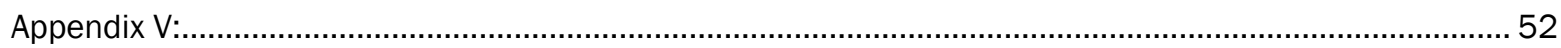

SUMMARY TABLES OF other health outcomes associated with PE/E...........................................52

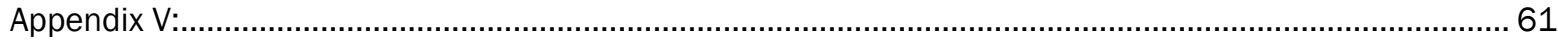

SUMMARY TABLES OF program descriptions and literature reviews ...............................................61

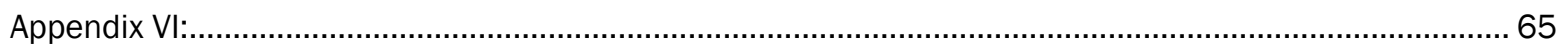

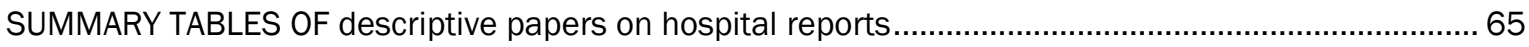




\section{List of Abbreviations}

$\begin{array}{ll}\text { ANC } & \text { Antenatal care } \\ \text { BP } & \text { Blood pressure } \\ \text { CFR } & \text { Case fatality rate } \\ \text { CS } & \text { Cesarean section } \\ \text { dBP } & \text { Diastolic blood pressure } \\ \text { DFID } & \text { Department for International Development } \\ \text { EML } & \text { Essential Medicines List } \\ \text { EmOC } & \text { Emergency obstetric care } \\ \text { EmONC } & \text { Emergency obstetric and newborn care } \\ \text { HDP } & \text { Hypertensive disorders of pregnancy } \\ \text { HELLP } & \text { Hemolysis, elevated liver enzymes, low platelet count } \\ \text { LBW } & \text { Low birth weight } \\ \text { MCSP } & \text { Maternal and Child Survival Program } \\ \text { MD } & \text { Maternal death } \\ \text { MDG } & \text { Millennium development goals } \\ \text { MgSO } 4 & \text { Magnesium sulphate } \\ \text { mmHg } & \text { Millimeters of mercury } \\ \text { MMR } & \text { Maternal Mortality Ratio } \\ \text { MOH } & \text { Ministry of Health } \\ \text { Ob/Gyn } & \text { Obstetrician and gynecologist } \\ \text { PE/E } & \text { Pre-eclampsia and eclampsia } \\ \text { PHC } & \text { Primary healthcare center } \\ \text { PIH } & \text { Pregnancy-induced hypertension } \\ \text { PNC } & \text { Postnatal care } \\ \text { PTB } & \text { Preterm birth } \\ \text { RH } & \text { Reproductive Health } \\ \text { SBP } & \text { Systolic blood pressure } \\ \text { USAID } & \text { United States Agency for International Development } \\ \text { WHO } & \text { World Health Organization } \\ & \end{array}$





\section{Background and Introduction}

Despite significant declines in maternal mortality rates, sub-Saharan Africa continues to face the burden of maternal deaths due to pregnancy related complications. Nigeria is one of the ten most dangerous countries for a woman giving birth and is reportedly responsible for $14 \%$ of the world's maternal deaths (National Population Commission [Nigeria] \& ICF International, 2014). Nigeria's MMR is estimated to be 576 deaths per 100,000 live births; one in 30 women in Nigeria will die from a cause related to pregnancy or childbirth (NPC \& ICF International, 2014). Poor health systems, lack of trained staff and quality of care, low levels of education, poverty, patriarchal societies and women's lack of agency to make decisions about their own healthcare needs are some of the factors contributing to the high maternal mortality and morbidity (NPC \& ICF International, 2014)

Pre-eclampsia and eclampsia (PE/E), pregnancy-related hypertensive disorders, are consistently cited as a leading cause of maternal morbidity and mortality Nigeria. In addition to maternal morbidity and mortality, PE/E can increase the likelihood of preterm or stillbirth (Onyearugha, \& Ugboma, 2012; Olusanya \& Solanke, 2012b; Owolabi et al., 2008). Both PE/E are preventable and the deaths due to PE/E can be avoided through timely detection and management of complications during and after pregnancy (The World Health Organization, 2011).

To fully appreciate the enormity of the problem at country level, we conducted a systematic review of published papers on PE/E in Nigeria from 2000-2015 in order to understand the key challenges, gaps and interventions related to the prevention and treatment of pre-eclampsia and eclampsia.

\section{WHAT IS PRE-ECLAMPSIA AND ECLAMPSIA?}

While the medical cause of eclampsia is unknown and definitions of the condition vary, there are some generallyaccepted signs and symptoms that are used to diagnose pre-eclampsia and eclampsia in pregnant women. Preeclampsia is a condition where a woman experiences a rapid elevation of blood pressure to $\geq 140 / 90 \mathrm{mmHg}$ (hypertension) and high levels of protein in the urine (significant proteinuria $\geq 0.3 \mathrm{~g} /$ day or $\geq 30 \mathrm{mg} / \mathrm{mmol}$ of urinary creatinine in random sample) after 20 weeks gestation (Magee et al., 2015). If untreated, it can progress to eclampsia, characterized by seizures, and other complications such as kidney or liver damage and ultimately death of the mother and/or fetus.

Diagnosing pre-eclampsia and managing it before it progresses to severe pre-eclampsia or eclampsia is a critical strategy to promote maternal and newborn health. Pre-eclampsia can be managed and eclampsia can be prevented by routine screening of blood pressure and protein levels in urine for pregnant women during antenatal care (ANC) visits. Health care providers can manage high BP in pregnant women using antihypertensive drugs that are safe during pregnancy, prevent and control eclamptic convulsions with injectable magnesium sulphate $\left(\mathrm{MgSO}_{4}\right)$ and, if at PHC facility, should refer the woman for follow-up monitoring and management of $\mathrm{PE} / \mathrm{E}$. 


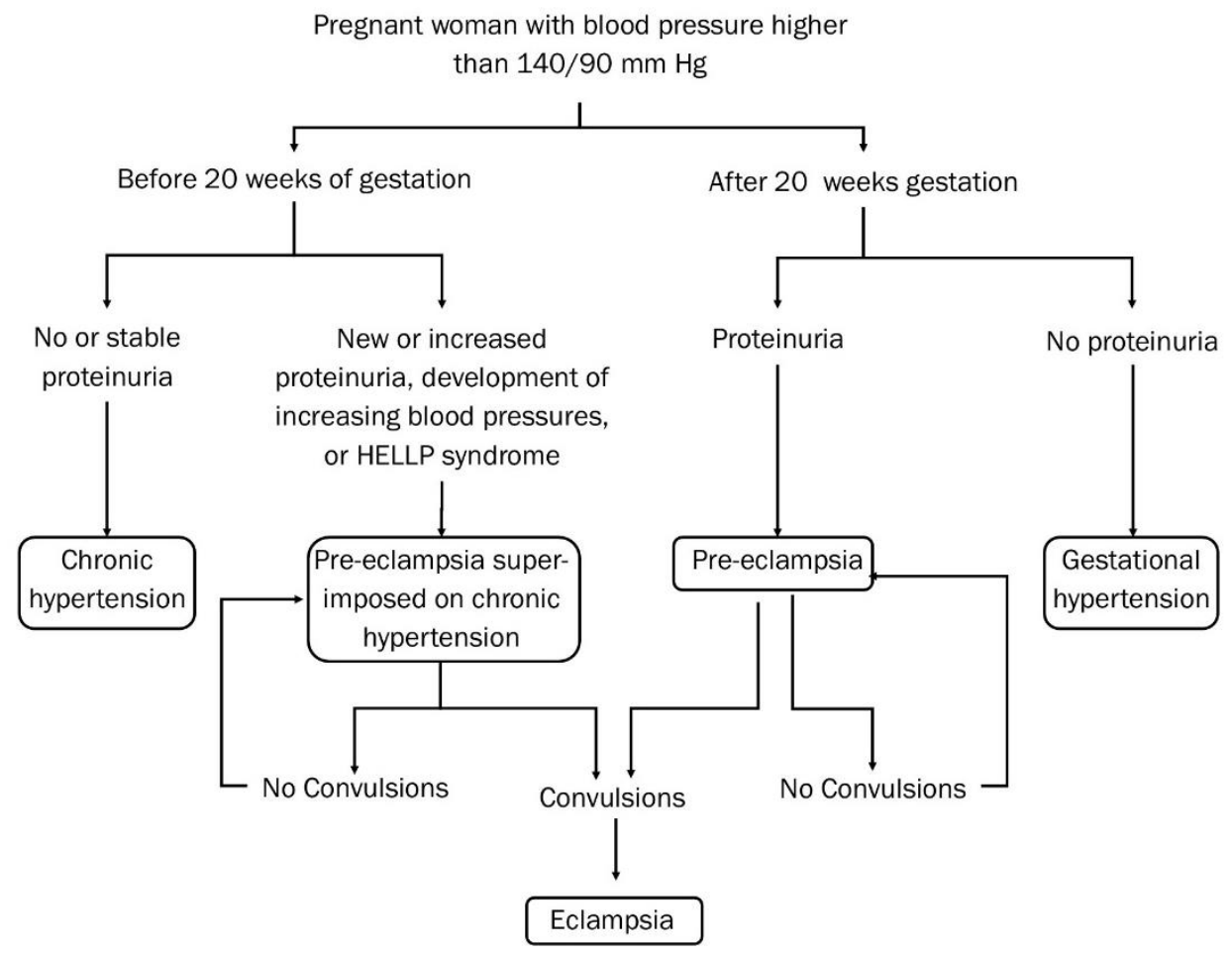

Adapted from: Wagner, L.K. (2004)

The World Health Organization (WHO) recommends three main evidence-based approaches to prevent maternal mortality due to PE/E (The World Health Organization, 2011):

1) Preventing the incidence of $P E / E$ by screening all pregnant women for signs and symptoms during antenatal care (ANC) check-ups. Preventative interventions include: calcium supplementation during pregnancy, low-dose aspirin prophylaxis and family planning methods to delay pregnancies.

2) Detecting early signs of PE by measuring blood pressure and protein levels in the urine during ANC visits to monitor and manage pre-eclampsia.

3) Managing severe cases of $\mathrm{PE} / \mathrm{E}$ by administering anti-convulsant therapy-magnesium sulphate $\left(\mathrm{MgSO}_{4}\right)$-to stop seizures followed by careful monitoring of the pregnant mother and her fetus and plan timed delivery of the baby.

The World Health Organization recommends use of $\mathrm{MgSO}_{4}$ as the standard method of preventing eclampsia in women with severe pre-eclampsia and of treating eclampsia (The World Health Organization, 2011). Women treated with $\mathrm{MgSO}_{4}$ have a $67 \%$ lowered risk of recurrent seizures compared to women who were treated with diazepam and phenytoin (Euser \& Cipolla, 2009). Despite its proven efficacy, this inexpensive drug is often underutilized for various reasons including lack of awareness and continued use of outdated methods (like diazepam and phenytoin), poor access to supplies, and insufficient number of trained personnel to administer $\mathrm{MgSO}_{4}$ (Yeager \& Patel, 2012). 


\section{PRE-ECLAMPSIA AND ECLAMIPSIA IN NIGERIA}

In Nigeria, approximately $34 \%$ of pregnant women receive no antenatal care, putting them at higher risk of maternal mortality (NPC \& ICF International, 2014). A recent, nationwide cross-sectional survey found that preeclampsia and eclampsia is the leading cause of maternal mortality in Nigeria and is responsible for $28.2 \%$ of maternal deaths; the other main contributors to maternal mortality are hemorrhage (24.4\%) and pregnancyrelated infection/sepsis (14.2\%) (Oladapo et al., 2015).

This systematic review of peer-reviewed literature published after 2000 aims to identify the interventions adopted to treat and manage pre-eclampsia and eclampsia. It specifically looks at issues around the quality of care, gaps in the evidence, and barriers to accessing services for PE/E in Nigeria.

\section{NIGERIAN HEALTH SYSTEM AND MATERNAL HEALTH POLICIES}

Nigeria is Africa's most populous nation of 162.5 million people. The Nigerian health system divides hospitals into primary, secondary, and tertiary hospitals with referral linkages between them (Tukur et al, 2009). In addition, Nigeria divides levels of governance into three distinct and independent entities, which are: federal, state, and local governments. The tertiary healthcare systems are managed by the federal government, the secondary institutions by the state government and the primary health care by the local government authorities, with no formal connection between these levels of care (Tukur et al, 2009). Patients with Pre-eclampsia and eclampsia are often referred from primary to secondary and tertiary health facilities for management. Delays in care are common due to lack of knowledge from the patient and poor understanding of the seriousness of the condition, as well as differing governance structures in the healthcare system.

Some of the key national policies and strategies adopted in Nigeria to address the high MMR include: Safe Motherhood Initiative launched in Nairobi in 1987, the road map for accelerating the attainment of MDG 4 and MDG 5 in 2005, FIGO's Safe Motherhood and Newborn Health Committee Initiative (2006-2011), the Integrated Maternal Newborn and Child Health (MNCH) Strategy in 2007, the Midwives Services Scheme (2009) which was launched by the National Primary Healthcare Development agency, USAID's Saving Mothers, Giving Life initiative (2012) and their Maternal and Child Survival Program (MCSP) and DFID's Maternal and Newborn Child Health Programme. The Federal Ministry of Health has included all of the necessary drugs for the management of hypertensive disorders of pregnancy (Labetalol, Hydralazine, Methyldopa, Nifedipine, magnesium sulphate, and calcium gluconate), on the national Essential Medicines List (EML) which was last updated in 2010 (Federal Ministry of Health Nigeria, 2010). The inclusion of these drugs on the EML means that every facility should maintain a regular supply of these medications; though this is not always the case. While some of these efforts have put a focus on the high maternal mortality rate in Nigeria, much remains to be done to address some of the challenges in the delivery of services for the prevention and treatment of pre-eclampsia/eclampsia. It will be necessary to re-visit some of the policies and on-going programs and explore how we may improve some of the gaps in health management to achieve better maternal health. 


\section{Methods}

This systematic literature review was conducted in three phases to collect, organize and analyze the published literature on pre-eclampsia and eclampsia in Nigeria.

\section{IDENTIFYING ARTICLES FOR REVIEW}

\section{Search of Databases}

The research team developed two sets of key terms related to pre-eclampsia and eclampsia that captured citations for peer-reviewed papers related to detection, management, and prevention of PE/E (Appendix I). The first search was designed to capture results that do not mention PE/E explicitly and the second search included the MeSH terms for PE/E and the rare complication known as, HELLP syndrome. The two searches were run in bibliographic databases including: PubMed, ScienceDirect, World of Science, Cochrane, POPLINE, and Wiley Online Library. These searches used a combination of terms linking various aspects of the diagnosis, treatment, and prevention of pre-eclampsia, eclampsia and hypertensive disorders of pregnancy. Searches were limited to articles published from 2000 to 2015 (April).

To accommodate the large number of key terms included in the second search, the terms were divided into three sub-searches to avoid any inadvertent omissions. The exact combinations of search terms used can also be found in Appendix I. The three sub-searches resulted in a high volume of duplicate citations.

\section{Google Search}

In an effort to identify any articles that may have been missed during the database searches, a simple google search was done using the following search terms:

"eclampsia" or "pre eclampsia" or "preeclampsia" or "pre-eclampsia" AND Nigeria

From the articles identified, the same search was run on the website or database hosting those articles. These sites included: Hindawi.com, African Journals Online (AJOL), Journal of Obstetrics and Gynaecology Canada (JOGC), Journal of Family and Reproductive Health (JFRH), Guttmacher Institute, International Federation of Gynecology and Obstetrics (FIGO). A final effort was made to ensure capture of any relevant articles by running two simplified searches in PubMed, results were duplicates with articles that had already been identified, and the searches were:

[“task shifting” AND Nigeria AND (“Magnesium sulfate” OR “magnesium sulphate”)]

and

[(“magnesium sulfate” OR “magnesium sulphate”) AND Nigeria].

Articles were excluded prior to phase I review if they were duplicate citations, if they pertained to non-human subjects, or if it was evident from the title that the article was not related to Nigeria (e.g. specifically identified the location of the study as somewhere other than Nigeria).

Titles and abstracts for the articles were imported into an excel spreadsheet adapted from "Excel Workbook for 2 Screeners" by Helena VonVille, licensed under a Creative Commons Attribution-NonCommercial-ShareAlike 3.0 Unported License, available online at http://libguides.sph. uth.tmc.edu /excel_SR_workbook. 


\section{PHASE I: EXCLUSION CRITERIA}

During Phase I of the systematic review two independent reviewers KK and IC conducted title and abstract screening to determine if the abstracts should be included or excluded in the next phase of the review. Abstracts were excluded if they were:

1) Not about Nigeria,

2) Not related to pregnancy; (for example: abstracts about male subjects and abstracts that discussed hypertension but not in pregnancy were excluded),

3) Not related to PE/E or associated risk factors, symptoms, or complications.

The two screeners then reconciled their reviews and in cases where it was unclear from the abstract if an article would provide relevant information, the screeners consulted the full text of the article.

\section{PHASE II: INCLUSION AND EXCLUSION}

In the second phase, the two reviewers read the full texts of the remaining articles to determine their relevance and eliminated any papers that were not related to PE/E, did not focused enough on Nigeria or did not provide any substantive data or observations specific to Nigeria, and any papers for which a full text could not be acquired.

\section{PHASE III: CATEGORIZATION}

Finally, the remaining articles were sorted into five types of papers-based on the main topic of each-that were found during the systematic review.

1) Intervention: papers that explore questions related to prevention and treatment of $P E / E$

2) Potential risk factors for pre-eclampsia and eclampsia

3) Other health outcomes associated with pre-eclampsia and eclampsia

4) Descriptive papers: including program descriptions/summaries and literature reviews

5) Reviews of hospital case files summarizing maternal mortality rates, causes of maternal mortality and the proportion of maternal mortality attributable to PE/E (and other hypertensive disorders in pregnancy).

The goal was to identify articles that presented evidence on interventions that addressed the diagnosis, treatment, or prevention of pre-eclampsia or eclampsia. 


\section{Results}

After removing duplicate citations and those that were obviously unrelated to this review, the initial database searches identified 520 abstracts which were included in Phase I review. The two reviewers removed 338 articles that were deemed to not fulfill the inclusion requirements for Phase I. During Phase II, 37 articles were removed because they did not provide enough, relevant information specific to Nigeria or a full text document could not be located (details in Appendix II). A total of 145 articles were included in the systematic review.

\section{FIGURE 2 Flow diagram of systematic review methods and results}

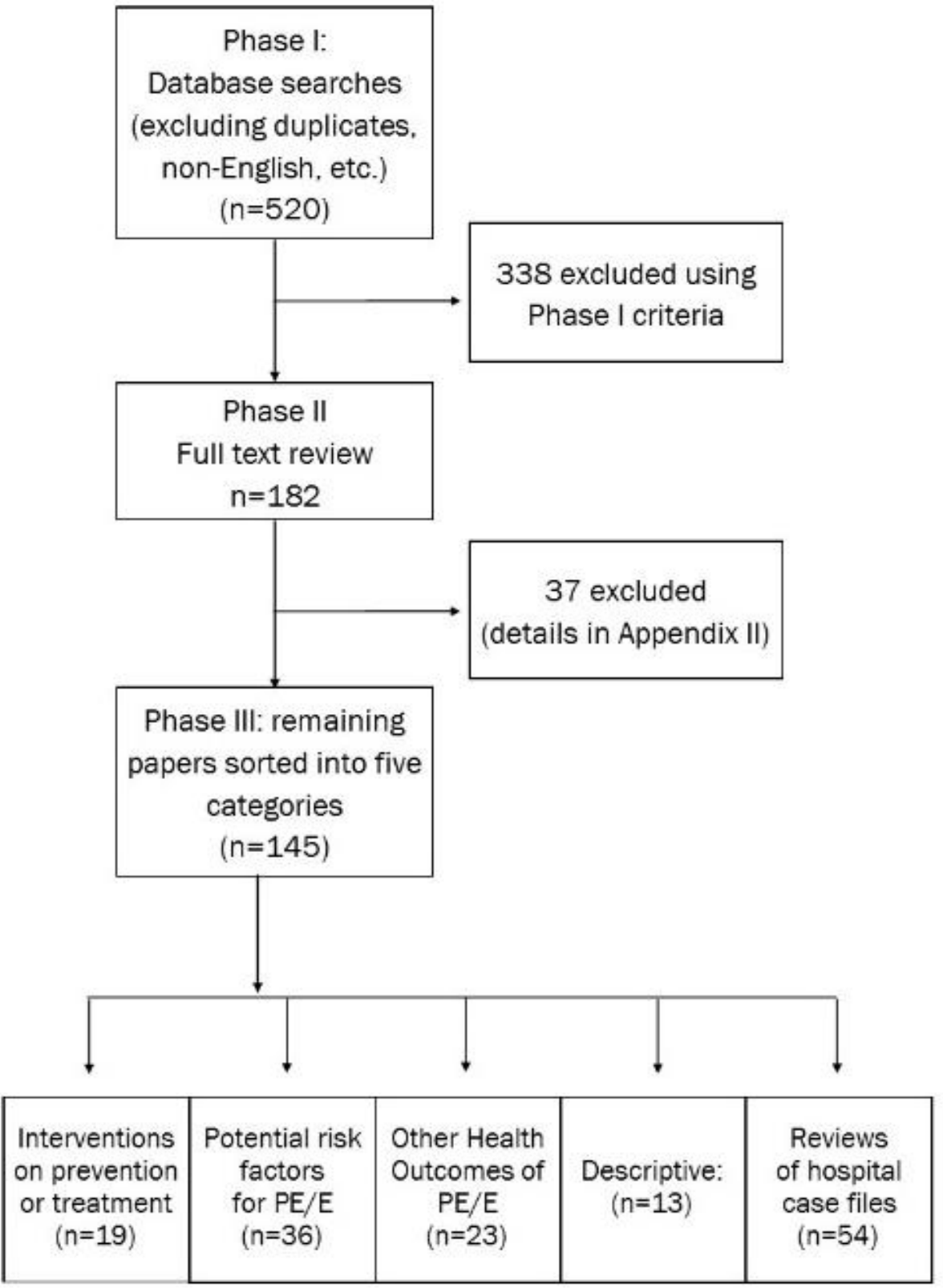




\section{SUMIMARY OF TOPICS FROM THE LITERATURE}

\section{Strategies for prevention and treatment of PE/E}

Nineteen studies relating to strategies for the prevention and/or treatment of PE/E were identified in this systematic review. Key data was extracted from these papers and compiled in a summary table (see Appendix III). These articles look at possible strategies for reducing mortality due to pre-eclampsia and eclampsia in Nigeria.

There were six major topics that emerged from these nineteen papers looking at best practices for preventing and treating $\mathrm{PE} / \mathrm{E}$ including: confirming $\mathrm{MgSO}_{4}$ is safe and effective, testing different dosing mechanisms, determining different methods for delivering patients with $\mathrm{PE} / \mathrm{E}$, improving case monitoring, creating and incorporating policy and management guidelines, and re-training of providers/task-shifting to lower cadres.

\section{$\mathrm{MgSO}_{4}$ is safe and effective}

Two papers confirm that magnesium sulphate is a safe and effective treatment for eclampsia and is a better option than other anticonvulsants like diazepam. Altman et al. performed a randomized placebo-controlled trial (known as the Magpie Trial) that showed that in 33 countries (including Nigeria) which demonstrated that $\mathrm{MgSO}_{4}$ is safer and more effective for controlling fits in eclamptic women than diazepam (Altman et al., 2002). The Magpie Trial was the first large, multi-country, randomized trial to generate evidence on the safety and efficacy of $\mathrm{MgSO}_{4}$ in women with eclampsia; this study lead to the determination that $\mathrm{MgSO}_{4}$ is the drug of choice and should be used over other anticonvulsants to control eclamptic fits.

The second paper, Ugwu et al. involved a before-and-after comparison of health outcomes based on retrospective case review from hospital records (Ugwu et al., 2011). During the three year study period, the University of Nigeria Teaching Hospital, Enugu, saw 77 cases of severe PE; 47 of whom were treated with diazepam and 30 of whom received $\mathrm{MgSO}_{4}$. Only one woman experienced recurrent seizures, and she had been treated with diazepam. During the study, no maternal deaths occurred due to severe PE, however, women in the diazepam group were more likely to experience prolonged hospital stay.

\section{$\mathrm{MgSO}_{4}$ dosage}

There are currently two predominant regimens for administering $\mathrm{MgSO}_{4}$ to women with severe $\mathrm{PE}$, impending eclampsia, or eclampsia: the Pritchard regimen and Zuspan regimen. The Pritchard regimen has been considered the 'gold standard' treatment method in low resource settings since 1925, but there is no evidence to show that this is best and most efficient mode of treating convulsions associated with PE/E. The Zuspan regimen requires more medical skills and equipment (involves setting up an infusion pump).

Four papers identified in this review looked at the question of dosage and tested alternate regimens. One was a descriptive comparative study conducted at the Federal Medical Centre in Katsina where women presenting with severe PE during the two study periods received a different dosage of $\mathrm{MgSO}_{4}$ (Okusanya et al., 2012). The 54 women who were enrolled during the first study phase received a $10 \mathrm{~g}$ dose of $\mathrm{MgSO}_{4}$ and 49 women in the second study phase received the $14 \mathrm{~g}$ associated with the standard Pritchard regimen. Overall, the health outcomes from both groups were comparable: similar rates of vaginal delivery, onset of convulsion/recurrent convulsion, maternal death, and neonatal Apgar score were not significantly different between the two groups.

Ekele and Ahmed conducted an experimental pilot in 2002-2003 that used the same loading dose of $\mathrm{MgSO}_{4}$ but limited the maintenance doses for 12 hours following the loading dose (compared to the 24 hours stipulated in the Pritchard regimen)(Ekele \& Ahmed, 2004). Thirty-three women participated in this study and the results seem to indicate that the primary outcome of interest-rate of recurrent convulsion-in these women (6.0\%) is comparable to the rate documented in the large $\mathrm{MgSO}_{4}$ Collaborative Eclampsia Trial (Magpie Trial) that followed the standard, Pritchard regimen (4.7\%). 
The other two papers looking at the dosage question were randomized control trials. Chama and Geidam randomized 112 patients into standard treatment group (Pritchard) and a shortened postpartum course which involved administering only two IM injections four hours apart (Chama \& Geidam, 2013). The findings indicated that the shortened postpartum course was as effective as the Pritchard regimen to manage eclampsia. While Chama and Geidam shortened the postpartum maintenance in their study, Abdul et al. instead modified the antepartum loading and maintenance doses (Abdul, et al., 2013). During their study, Abdul et al. randomized 72 patients into standard dose $(n=33)$ and low dose $(n=39)$ groups. The low dose regimen reduced the amount of $\mathrm{MgSO}_{4}$ required in the standard, Pritchard. The women in the low dose group received a $9 \mathrm{~g}$ loading dose (4g IV, $2.5 \mathrm{~g}$ in each buttock) followed by $2.5 \mathrm{~g}$ in alternate buttocks every four hours. Though the sample size was small, this study found no significantly different rates in maternal or perinatal mortality or in Cesarean section (CS) rate.

\section{Delivery methods for PE/E cases}

The only definitive treatment for eclampsia is to end the pregnancy by delivering the baby and placenta. It is, therefore, understandable that $\mathrm{PE} / \mathrm{E}$ leads to increased rates of cesarean section (CS) deliveries in populations with high rates of PE/E. Afolayan and Tukur explore two different aspects of labor and delivery in order to determine which methods have the best outcomes for mother and baby.

Afolayan et al. conducted a retrospective case review that compared complication rates between using general anesthesia or spinal anesthesia during caesarean section deliveries among eclamptic women (Afolayan et al., 2014). The study showed that maternal and perinatal survival among eclamptics are better among those who received spinal anesthesia during their caesarean section procedure.

Tukur examines the outcomes for eclamptic mothers and their babies who underwent caesarean section versus those who had labor induced using misoprostol (Tukur et al., 2007). Their study found that although both methods were effective, misoprostol requires more time to fully induce labor and should therefore only be used when prompt and safe caesarean section is not available.

\section{Improved case management and monitoring}

Case management and monitoring can be modified and improved and at different stages throughout the development of the condition; three papers looked at strategies to improve case management for women with $\mathrm{PE} / \mathrm{E}$. One looks at a strategy to manage early PE, one incorporates a tool for streamlining monitoring and treatment, and the third tests the role of serum magnesium levels in eclamptic patients as a way to prevent and detect $\mathrm{MgSO}_{4}$ toxicity.

In a prospective, case-control study conducted in Enugu, 749 consecutive cases of pre-eclampsia admitted to the University Teaching Hospital were recruited; 175 cases were deemed to be 'early onset' (before 30 weeks gestation) and made up the study group and 574 served as controls (Onah \& Iloabachie, 2002). All participants were tested for blood count, serum electrolytes, urea and creatinine, liver function, clotting profile, urinalysis and ultrasonography. When necessary, they were treated with antihypertensives (alpha-methyldopa used antepartum and hydralazine used in the event of a hypertensive crisis) and diazepam (to control convulsions). The women in the early onset group were conservatively managed using antihypertensives and diazepam until maternal and/or fetal risks meant that continued conservative management was considered dangerous; $80 \%$ gained more than two weeks gestation using this method of management. Women in the late onset group were delivered promptly, especially if the woman was beyond 34 weeks gestation. While conservative management may improve fetal outcomes, this study saw an increase in maternal morbidity and mortality among the study group participants which was likely due in part to facility delays and the unavailability of $\mathrm{MgSO}_{4}$. The authors suggest that conservative management has potential to improve fetal outcomes but in order to improve maternal outcomes, institutional delays need to be reduced and $\mathrm{MgSO}_{4}$ needs to be available.

Ameh et al. developed a monitoring chart that simplified the paperwork and compiled all relevant details onto one sheet (Ameh et al., 2012). The improved chart, the LIVKAN chart allows for the patient's blood pressure to be tracked over time as well as the number and timing of convulsions, patient's level of consciousness, 
proteinuria, respiratory rate, deep tendon reflex. Furthermore, any drugs needed to manage high BP (hydralazine, nifedipine, labetolol), eclamptic fits $\left(\mathrm{MgSO}_{4}\right)$, or $\mathrm{MgSO}_{4}$ toxicity (calcium gluconate) are also recorded in the chart. Missing from the chart, however, is methyldopa, another antihypertensive that is usually affordable and available. In order to assess the effectiveness and acceptability of the LIVKAN chart, Ameh et al. trained 118 skilled birth attendants on its use and followed up with questionnaires. The study found that $98 \%$ of the participants thought that the LIVKAN chart was an improvement over the existing monitoring system and would be useful at their level and at lower levels to improve care and documentation of referral. The challenges cited include: low availability of blank charts and high workload due to paperwork. Overall, the chart appears to improve monitoring of $\mathrm{PE} / \mathrm{E}$ by combining monitoring and treatment guidelines and allowing for 24 hour surveillance of a patient experiencing $\mathrm{PE} / \mathrm{E}$ in one single page.

Finally, whenever a patient is treated with $\mathrm{MgSO}_{4}$, she must be monitored for indications of toxicity from $\mathrm{MgSO}_{4}$. Ekele and Badung quesiton the role of serum magnesium levels in patients receiving $\mathrm{MgSO}_{4}$ as an indicator of possible toxicity. During their prospective study, they recruited 19 patients who presented with eclampstic convulsions and were treated using $\mathrm{MgSO}_{4}$; blood samples were taken from patients prior to administration of $\mathrm{MgSO}_{4}$ to assess whether there was a significant change in serum magnesium levels (Ekele \& Badung, 2005). This small study found that serum magnesium levels in eclamptic patients do not change drastically and they remain within therapeutic levels and conclude, therefore, that serum magnesium level estimation is not necessary in patients with eclampsia being treated with $\mathrm{MgSO}_{4}$.

\section{Policy and management guidelines}

Establishing policies and institutionalizing guidelines support clinical efforts to manage cases of PE/E. Three papers included in this review examined the impact of guidelines and policies on maternal mortality related to $\mathrm{PE} / \mathrm{E}$. Nkwocha et al. looked at the impact of a global call to action-the Safe Motherhood Initiative-that was adopted in Nigeria in 1990 and called for a reduction in maternal mortality by $50 \%$ by 2000 . Igwegbe et al. assessed the impact of a facility-specific policy and Ezugwu et al. looked at guidelines within a specific facility to assess the effect on maternal mortality due to PE/E.

Nigeria launched the Safe Motherhood Programme in 1990 with the express purpose of reducing maternal mortality by half in ten years (Nkwocha et al., 2006). Nkwocha et al. reviewed hospital cases from eight years before (1981-1989) and eight years after (1990-1998) the introduction of this initiative in Nigeria. The study found that while the overall MMR decreased by $8 \%$ between the two study periods, maternal deaths due to PE/E increased after 1990. Prior to 1990 , PE caused $4.4 \%$ and eclampsia caused $10.5 \%$ of maternal deaths, after 1990 these rates increased to $13.9 \%$ and $17.9 \%$, respectively. These findings indicate that PE/E represents a priority area that requires more focus in order to reduce the associated maternal death.

In 2005, the Nnamdi Azikiwe University Teaching Hospital (NAUTH) introduced a "Service Compact" (SERVICOM) contract in response to a federal proclamation to provide all Nigerians with "basic services to which each citizen is entitled in a timely, fair, honest, effective and transparent manner" (Igwegbe, Eleje, Ugboaja, \& Ofiaeli, 2012). The SERVICOM charter at NAUTH included mandates including: elimination of fee-for-service for all emergency services (which included emergency obstetric services), prompt and appropriate treatment, and monitoring of services and record keeping. Igwegbe et al. reviewed hospital records from before and after the introduction of the SERVICOM charter at NAUTH to determine if the policy had any effect on maternal mortality. Overall, the maternal mortality rate at the facility from 2004-2010 was 1,098 per 100,000 live births and eclampsia contrubuted $25 \%$ of the maternal deaths. Before SERVICOM, the 2004 maternal moratily rate was 1,567 per 100,000 live births compared to 691 per 100,000 in 2010. Igwegbe et al. showed that introducing a policy like the SERVICOM charter can improve quality of care, timeliness of treatment and maternal health outcomes which may have implications for maternal outcomes related to PE/E.

In 2008, the Enugu State University Teaching Hospital adopted evidence-based guidelines aimed at reducing maternal mortality (Ezugwu et al. 2014). This study reviewed hospital records from three years before the 
institutionalization of the guidelines and three years after in order to compare the maternal outcomes at the facility and to determine if the guidelines had an impact. The guidelines were identified through PubMed and Google scholar; they were adapted to the local context and included guidelines on the management of severe PE using the Pritchard regimen. The three years after the introduction of the guidelines at the facility showed a 43.5\% reduction in MMR when compared with the three years prior to the guidelines. The case fatality rate fell by $80 \%$ (from $15.8 \%$ to $2.7 \%$ ) after introducing the guidelines and training providers on them. This study by Ezugwu et al indicates that institutionalization and training on guidelines related to management of PE/E can reduce maternal mortality.

\section{Re-training and task-shifting}

The final major theme that emerged from the literature on strategies for improving prevention and management of $P E / E$ is focused on increasing access through provider knowledge and skills. Five studies were on training, retraining and task-shifting as a way of improving access and quality of care for patients with severe $\mathrm{PE} / \mathrm{E}$.

In a multi-state study, Okonofua et al. conducted a before-and-after trial in six health facilities that sought to test the impact of training various professionals (Ob/Gyns, doctors in training, nurses, midwives and others) on the proper treatment of PE/E cases using the Pritchard regimen, antihypertensives, and monitoring the patient (Okonofua et al., 2013). To establish a baseline and identify gaps in knowledge, the researchers reviewed hospital records from January to May 2008 and conducted in-depth interviews (IDIs) with providers to inform development of the training materials. The endline data was prospectively collected for one year after the intervention. Incidence of eclampsia was comparable at baseline and endline but the case fatality rate decreased from $15.1 \%$ at baseline to $3.2 \%$ at endline. This study found that the trainings successfully built the capacity of the healthcare providers to safely use $\mathrm{MgSO}_{4}$ and effectively reduced deaths due to eclampsia.

Ishaku et al. conducted a case-control study where they assessed whether lower-cadre health workers could detect severe $\mathrm{PE} / \mathrm{E}$ and safely administer the loading dose of $\mathrm{MgSO}_{4}$. In their study, ten primary health care facilities in Kano state were included, 5 made up the experimental arm and 5 were controls (Ishaku et al., 2013). At the experimental facilities, health workers received training on how to recognize cases of severe $\mathrm{PE} / \mathrm{E}$ and learned how to administer the loading dose of $\mathrm{MgSO}_{4}(10 \mathrm{~g} \mathrm{IM})$ and refer women for follow up care. In addition to recognizing and initiating treatment for severe $\mathrm{PE} / \mathrm{E}$, the $\mathrm{PHC}$ providers also received instruction for detecting $\mathrm{MgSO}_{4}$ toxicity and treating it with calcium gluconate. The PHC providers at the control facilities did not give $\mathrm{MgSO}_{4}$ or diazepam. During this study, a higher proportion of women defaulted from experimental facilities than in the control facilities; this was potentially due to the immediate, yet temporary, effect of $\mathrm{MgSO}_{4}$. This study demonstrated that PHC providers can safely and effectively administer the loading dose of $\mathrm{MgSO}_{4}$ in patients with severe $\mathrm{PE} / \mathrm{E}$, however referral mechanisms need to be strengthened to reduce the $75 \%$ default rate seen in this study.

The remaining three papers are reporting on data collected during the same or complementary studies that were implemented in ten facilities in Kano state from February 2008 to December/January 2009 (Okereke, Ahonsi, Tukur, Ishaku, \& Oginni, 2012; Tukur et al., 2011; Tukur et al., 2013).

The intervention trained twenty-five individuals on evidence-based management of hypertensive disorders of pregnancy and use of $\mathrm{MgSO}_{4}$ (five hospital board officials and one midwife and one doctor from each of the ten facilities). These 25 people were considered "Master Trainers" and together trained another 160 health workers. These papers report a baseline case fatality rate of $20.9 \%$ compared to $2.3 \%$ after the intervention.

This evidence-based intervention was successful because it engaged with stakeholders and it is replicable (Tukur et al., 2011). Training providers on protocols for the treatment of severe PE/E using $\mathrm{MgSO}_{4}$ was determined to be an effective strategy to reduce case fatality due to eclampsia without incurring any significant increase in cost (Okereke et al., 2012). This effective, low-cost, replicable intervention has a positive effect on maternal and fetal mortality and morbidity and should be implemented on a wider scale (Tukur et al., 2013). 


\section{Demonstrated and Potential Risk Factors}

While the biological mechanism for developing eclampsia remains unknown, many studies look at various attributes or conditions in an effort to identify risk factors for developing PE/E. Among the potential risk factors explored in the literature are: maternal ethnicity, adolescent mothers, sickle cell anemia, parity, and history of hypertension or prior pre-eclampsia. Thirty-six papers looked at demonstrated or potential risk factors for PE/E that had the potential to improve early detection (Appendix IV).

Previously demonstrated risk factors for PE/E that appear in the literature from Nigeria and include: low parity, young age, multiple gestation, history of chronic high blood pressure, previous pre-eclampsia, and not registering or booking at a health facility for ANC (Adokiye \& Isreal, 2015; Anorlu et al., 2005; Olusanya, 2011; Osungbade et al., 2008; Owolabi et al., 2008). Three papers looked specifically at young age and determined that adolescence is a risk factor for PE/E, though the papers did not look at explanations for this fact (Adeyinka et al., 2010; Airede \& Ekele, 2003; E. I. Nwobodo \& Panti, 2012).

While rise in blood pressure is known to be associated with $\mathrm{PE} / \mathrm{E}$, one paper investigated whether or not a relative rise versus absolute rise in BP would be better to predict maternal and fetal outcome. After following a cohort of 478 women and tracking blood pressure levels throughout the study period, Onah concluded that fetomaternal outcomes were not significantly affected by relative rise in diastolic BP and concluded that absolute BP is a better predictor of fetomaternal outcome (Onah, 2002).

Twenty-one other papers looked at potential risk factors relating to biomarkers in pregnancy. Each looked at a specific set of biological measures to determine if there were any observable trends or associations between the biomarker and the development of PE/E. These included: various antioxidant vitamins, magnesium or magnesium serum levels, trace element levels, lysosomal enzymes or enzymic antioxidants, among others (Appendix IV). Based on these studies, elevated levels of haptoglobin, malondialdehyde, phenylalanine concentration, blood lead and homocysteine levels were observed in pre-eclamptic women and may contribute to the development of PE/E. Low serum concentrations in zinc, copper, manganese and magnesium, and low plasma calcium, vitamin $C$ and $E$ levels could indicate $P E / E$ or risk of $P E / E$ in pregnant women.

The remaining papers tested the effect of maternal ethnicity, seasonality, past abortion and change in paternity, socioeconomic status and polygamy on a woman's risk of developing PE/E (Abubakar et al., 2009; Attahir, et al., 2010; Chigbu et al., 2009; Familoni et al., 2008; Okafor \& Ezegwui, 2010; Olayemi et al., 2010; Olayemi, et al., 2010). All of these studies were specific and small but their findings indicate the potential need for further research into risk factors for $\mathrm{PE} / \mathrm{E}$. Abubakar et al. found that the Fulani ethnic group was more likely to progress from PE to eclampsia when compared to Hausa and Kanuri women. Attahir et al. learned that seclusion and polygamy did not have an effect on rates of PE. Okafor reported from a retrospective review of hospital records that women with PE were more likely to undergo CS during the rainy season.

While these findings are certainly interesting, they are looking only at a relatively small number of women and are not sufficient to consider these aspects as risk factors for PE/E.

\section{Other Health Outcomes associated with PE/E}

In addition to the common, known health outcomes of PE/E (edema, headache, seizure, and death), other health outcomes are associated with PE/E. Twenty-three papers identified during this review reveal other health outcomes that can affect mother and/or fetus including: fetal malnutrition, poor Apgar scores increased chance of cesarean section (CS), cardiac complications and persistent hypertension (Appendix V).

Among the less-common outcomes associated with PE/E were: orofacial injuries, loss of vision, and paralysis. The orofacial injuries are not caused by PE/E, however, but are the result of objects being forced into the mouths of eclamptic women in a misguided effort to mitigate consequences of the seizures (Adeyemo \& Rabiu, 2012; Ndukwe et al., 2004). While change in vision is a more common consequence of PE/E, total loss of vision occurs less often but one such case is reported in the literature (Waziri-Erameh et al., 2003). The literature also revealed 11 
a rare case of a 26-year old woman who was brought into a facility with postpartum eclampsia and was left quadriplegic, a rare yet real consequence of her eclampsia (Okafor \& Efetie, 2006).

Since $\mathrm{MgSO}_{4}$ only allows for the temporary management of eclampsia, many women suffering from the condition must be delivered pre-term; this leads to an increase in the number of caesarean section (CS) deliveries that are performed which, in turn, increases the woman's chance of suffering a morbidity or mortality from the procedure (Adeoye et al., 2013; Oladapo et al., 2004; Okafor \& Ezegwui, 2010; Okafor, 2009; Ozumba \& Anya, 2002). Further to the increase in caesarean sections and associated morbidities and mortality for the mother are the increased negative health outcomes for the fetus/baby. With an increase in pre-term deliveries, there is a heightened burden of low birthweight babies (Olusanya \& Solanke, 2012a, 2012b; Onyearugha \& Ugboma, 2012a).

Another health outcome of PE/E is HELLP syndrome, a dangerous condition that complicates eclampsia with hemolysis, elevated liver enzymes, and low platelets. HELLP syndrome causes the internal organs to shut down, and left untreated, the mother's health, as well as the fetus' health, will quickly deteriorate (Makinde, 2009).

It is important to remember that PE/E has negative health effects on the fetus/newborn as well as the mother. Eight papers reviewed discuss the fetal/neonatal outcomes associated with PE/E including fetal malnutrition, low birth weight (LBW), preterm birth (PTB), low Apgar score and fetal death. For example, Onyearugha et al. conducted a study based on the hospital records for 48 babies delivered to eclamptic mothers in Abia state. The records showed that 13 babies were LBW <1500g, and $29(60 \%)$ were stillborn and four were severely asphyxiated; the authors suggest that these poor Apgar scores could be impacted by 'asphyxiogenic effect' in utero during eclamptic convulsions (Onyearugha \& Ugboma, 2012b).

\section{Program descriptions and literature reviews}

Thirteen of the papers reviewed were categorized as being descriptive articles and included: project summaries (three), literature reviews (five), purely cross-sectional studies (three), and editorial or correspondence articles (two). Some of the topics covered in these descriptive papers were: verbal autopsy to determine cause of pregnancy-related death in a population, assessment of nurse-midwife educators on causes of maternal mortality, determine whether brief summaries of these descriptive papers relating to PE/E in Nigeria can be found in Appendix VI.

\section{Summaries of hospital case notes and records for PE/E}

A majority of the papers collected for this review are a specific kind of a descriptive paper; they are summaries of hospital reports of eclampsia or, more broadly, maternal mortality. The 54 papers that fall into this category report maternal mortality ratios, the attributable proportion of MMR to PE/E, incidence of PE/E, and case fatality rate at a specific facility during a specific time period and do not provide any analysis or interpretation. The facilities are from across the country, with a greater concentration in the South West and South East (Figure 3). 


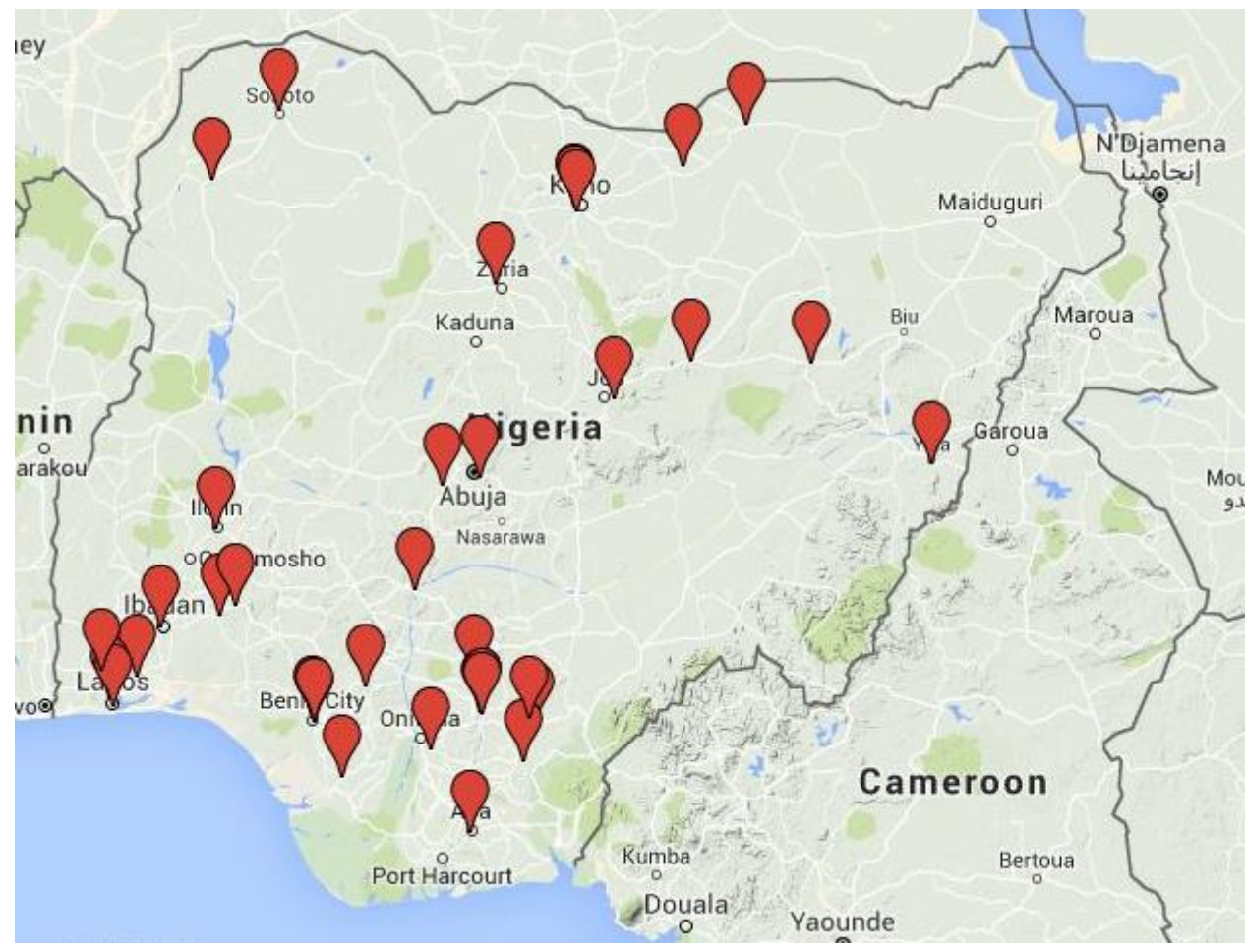

The MMRs reported in these papers cover specific periods of time over the last three decades; Olatunji et al. reviewed data from a facility in Sagamu in Ogun state that included cases from 1988-1997; their review found 92 maternal deaths out of 5,423 deliveries making the MMR at that facility at that time, 1,696 per 100,000 deliveries. The lowest MMRs reported include 463 per 100,000 live births (44 maternal deaths) at the Federal Medical Centre in Kogi state from 2005-2009 (Alabi et al., 2012) and 454 per 100,000 from Edo state in 19962000 (Onakewhor \& Gharoro, 2008). The highest MMRs reported among these summary papers include one from a rural referral hospital, Baptist Medical Centre, in Delta state. The cases reviewed were from 1994-2003 and revealed 115 maternal deaths out of 5,153 deliveries making the MMR=2,232 per 100,000 live births (Igberase \& Ebeigbe, 2007). Another extraordinarily high MMR of 2,849 per 100,000 deliveries comes from a tertiary facility that experienced 112 maternal deaths out of 3,931 deliveries from 2003-2007 (Kullima et al., 2009). The highest observed MMR comes from Olabisi Onabanjo University Teaching Hospital in Sagamu in Ogun state from 2000-2005 where 75 maternal deaths and 2,509 live births were recorded making the MMR= 2.989.2 per 100,000 live births (Oladapo et al., 2006).

In addition to reporting on MMRs at facilities, the authors also reported on the proportion of MMR that is attributable to $\mathrm{PE} / \mathrm{E}$. These proportions also varied, every paper that reported the proportion of maternal deaths caused by hypertensive disorders in pregnancy, PE/E, severe PE/E, eclampsia, was over ten percent (Figure 4). The proportions ranged from 12.4\% of 97 maternal deaths (Nwagha et al., 2010) to 42.2\% of 277 maternal deaths (Nwobodo \& Ahmed, 2011). 
FIGURE 4 Attributable proportion of maternal death due to PE/E as reported in the literature

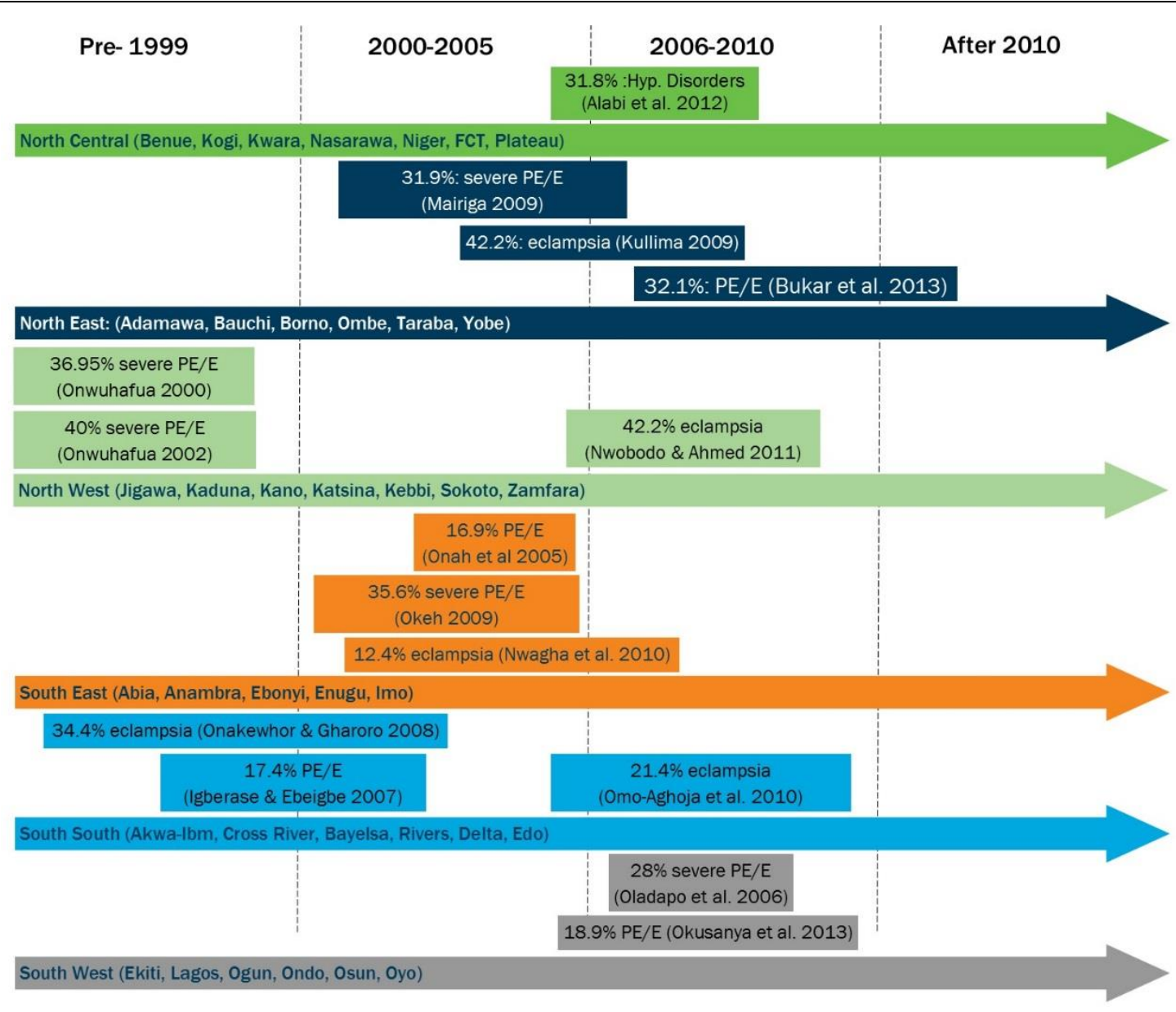

Two papers, examined 'maternal near miss' cases to get a larger sample size and a better idea of the causes of severe maternal outcomes even in cases where the woman survived. These also found that a large proportion of cases were due to $\mathrm{PE} / \mathrm{E}$. Adeoye et al. saw that hypertensive disorders in pregnancy (which they defined as severe PE/E) caused $37.3 \%$ of near miss cases at the maternity units of Obafemi Awolowo University Teaching Hospitals Complex in Ile-Ife from July 2006-June 2007. In a recent cross-sectional study of 91,724 live births, Oladapo et al. found 2,440 severe maternal outcomes (1,451 maternal near-miss and 998 maternal deaths). Of these 2,440 cases, hypertensive disorders (chronic hypertension and PE/E) were the most common cause and contributed $24 \%$ of the SMOs and eclampsia was found to be the most frequent complication and resulted in $20 \%$ of the maternal deaths (Oladapo et al., 2015).

The papers already discussed in this section were looking at all causes of maternal mortality/maternal near misses and reported on overall MMR and attributable proportion of maternal death to PE/E among other health conditions; the remaining summaries of hospital records look at reports from cases of PE/E specifically and report on prevalence/incidence and case fatality rates. Incidence/prevalence of PE/E ranged from very low: 0.42\% (Onwuhafua et al., 2001) and 0.75\% (Ikechebelu \& Okoli, 2002) to very high: $9.42 \%$ (Tukur, Umar, \& Rabi'u, 2007). For obstetric complications, the United Nations has set the maximum case fatality rate at $1 \%$ of cases; every paper reporting CFR in this literature review found CFR over $1 \%$, most were over $10 \%$ and one study found CFR as high as $42.22 \%$ (out of 45 cases) (Onwuhafua et al., 2001). 


\section{Discussion}

\section{GAPS IN PREVENTION OF PE/E}

Globally, aspirin and calcium are thought to have a protective effect for women at risk of developing PE/E. This potential prophylactic effect is only very briefly mentioned in a few papers and none of the studies test the effect of these two supplements on the incidence of PE/E. The effectiveness and impact of prophylactic aspirin and calcium are unknown in the Nigerian context.

\section{GAPS IN DETECTION OF PE/E}

\section{Terminology and clinical definitions}

Throughout the 145 full text articles reviewed in this paper, there is no consistency in terminology used or in clinical definitions for those terms; each paper provides their own definitions with some overlapping criteria.

Among the various terms used throughout the literature were: hypertensive disorders of pregnancy, mild pregnancy-induced hypertension $(\mathrm{PIH}), \mathrm{PIH}$, severe $\mathrm{PIH}$, chronic hypertension with superimposed pre-eclampsia, pre-eclamptic toxaemia (PET), severe PET, toxemia of pregnancy, the toxaemia syndrome, mild pre-eclampsia, pre-eclampsia, severe pre-eclampsia, imminent eclampsia, impending eclampsia and eclampsia.

Currently, with the plethora of accepted terms used to refer to varying degrees of PE/E severity, studies are forced to define the clinical parameters for each condition. While some of the definitions contain similarities or overlapping criteria, there are often specific differences between them. Below are a few examples of definitions from the literature

\section{Mild pre-eclampsia}

- "a blood pressure of $140 / 90 \mathrm{mmHg}$ on two occasions $6 \mathrm{~h}$ or more apart, or a rise of $30 \mathrm{mmHg}$ systolic or $15 \mathrm{mmHg}$ diastolic from mid-trimester values; proteinuria above (+) on two consecutive urine specimens and significant non- dependent oedema" (Okafor \& Okezie, 2005).

- "Pregnancy-induced systole hypertension of 140 to $<160 \mathrm{mmHg}$ (or diastole hypertension of 90 to $<110$ $\mathrm{mmHg}$ ) with proteinuria of $2+(100 \mathrm{mg} / \mathrm{dL}) "$ (Osinubi, Ajayi, \& Adegbola, 2009)

\section{Pre-eclampsia}

- "Preeclampsia, a multisystem disorder unique to human pregnancy is defined as the association of pregnancy induced hypertension with proteinuria of greater than or equal to $300 \mathrm{mg} / 24 \mathrm{~h}$ after 20 weeks of gestation" (Okafor \& Ezegwui, 2010)

- "Hypertension after the 20th week of gestation, the diastolic blood pressure $>110 \mathrm{mmHg}$ on admission, proteinuria $>30 \mathrm{mg} / \mathrm{dl}$ in random urine specimen or $>300 \mathrm{mg}$ in a $24 \mathrm{hr}$ urine specimen" (Makinde, 2011)

- "Hypertension (?140/90mmHg on two occasions $4 \mathrm{~h}$ apart) and proteinuria ( $\geq 0.3 \mathrm{~g} / \mathrm{dl})$ in the second half of pregnancy" (Adeyinka et al., 2010)

- "Hypertension (systolic pressure = $169 \pm 26.0 \mathrm{mmHg}$, diastolic pressure $=102 \pm 11.0 \mathrm{mmHg}$ ), significant proteinuria (368 $\pm 39 \mathrm{mg} / 24 \mathrm{~h}$ ), severe headache, abdominal pain and vomiting." (Akiibinu, Kolawole, Ekun, \& Akiibinu, 2013)

- "Significant proteinuria (>100 mg/day) and high blood pressure (>130/90 mm Hg) irrespective of weight of the patients or the presence of edema. The blood pressure must have manifested on at least two occasions 6 hours or more apart." (Arinola, Arowojolu, Bamgboye, Akinwale, \& Adeniyi, 2006) 
- "Blood pressure of $\geq 140 / 90 \mathrm{mmHg}$ on at least two occasions measured at least $6 \mathrm{~h}$ apart or a diastolic blood pressure of $110 \mathrm{mmHg}$ at any time or an increase of $30 \mathrm{mmHg}$ and $15 \mathrm{mmHg}$ in the systolic and diastolic blood pressures, respectively from the booking values or a mean arterial pressure of greater than $105 \mathrm{mmHg}$ " with "two midstream urine specimens more than $4 \mathrm{~h}$ apart with 2+ protein on dipstix testing or 1+ protein with measured specific gravity of 41.03 and < 8" (Chigbu et al., 2009)

- "Cerebral or visual disturbances, epigastric pain, pulmonary edema or cyanosis, a systolic blood pressure $\geq 140 \mathrm{~mm} \mathrm{Hg}$ or a diastolic blood pressure $\geq 90 \mathrm{~mm} \mathrm{Hg}$ and proteinuria."(Glew et al., 2004)

\section{Severe pre-eclampsia}

- "The blood pressure is persistently above $160 / 110 \mathrm{mmHg}$ and proteinuria above $5 \mathrm{~g} / 24 \mathrm{~h} \mathrm{(+++)}$ and symptoms of headache, blurring of vision, epigastric pain and oliguria." (UV Okafor \& Okezie, 2005).

- "New hypertension with blood pressure of $160 \mathrm{mmHg}$ systolic or diastolic blood pressure of $110 \mathrm{mmHg}$, or greater, arising after 20 weeks of gestation in a woman who was normotensive before 20 weeks gestation, associated with proteinuria [...] 2+ or more protein on urine dipstick." (Guerrier, Oluyide, Keramarou, \& Grais, 2013)

- "If any two of the following signs were present: (1) systolic blood pressure $>160 \mathrm{mmHg}$ or diastolic blood pressure >110 mmHg; (2) proteinuria (>3+ on dipstick [500 mg/dL]); (3) facial oedema." (Osinubi et al., 2009)

\section{Eclampsia}

- “...maternities that presented with fitting or fitted while on admission, had blood pressure equal to or greater than 140/90 $\mathrm{mm} \mathrm{Hg}$, at least 2 +proteinuria with or without edema, and had no past history of epilepsy." (B. Ekele, Bello, \& Adamu, 2007)

- "hypertension after the 20th week of gestation, the diastolic blood pressure $>110 \mathrm{mmHg}$ on admission, proteinuria $>30 \mathrm{mg} / \mathrm{dl}$ in random urine specimen or $>300 \mathrm{mg}$ in a $24 \mathrm{hr}$ urine specimen [...] plus headache, blurring of vision and upper abdominal pain [...] and seizures" (O. N. Makinde, 2011)

- "associated with convulsions, oliguria $(4400 \mathrm{ml} / 24 \mathrm{~h})$, increased tendon reflex, pain in the right hypochondriac region." (Adeyinka et al., 2010)

- "Occurrence of seizure and/or altered level of consciousness not caused by epilepsy or other convulsive disorders, with signs of severe preeclampsia." (Guerrier et al., 2013)

Creating specific and clear clinical definitions for these conditions is essential to ensuring that providers around the globe are able to appropriately diagnose and manage the symptoms related to PE/E. Generally speaking, "toxemia" is an outdated term that is not frequently used today to classify types of hypertensive disorders of pregnancy. Given the wide range of definitions related to hypertensive disorders in pregnancy, it is necessary to reduce the number of terms and simplify the definitions to move beyond the implication that interventions vary significantly between each classification, when in fact, the monitoring and management methods are not so different between mild PE and PE or severe PE and eclampsia.

\section{ANC attendance, content, and quality}

One message that comes through clearly in the literature is that "booked" patients are less likely to develop $\mathrm{PE} / \mathrm{E}$ when compared to "unbooked" women. This trend is not surprising as women who attend ANC will be more likely to be screened for PE/E and receive preventative care and careful monitoring before the condition worsens. Women who do not attend ANC are unlikely to be aware of any problem until eclamptic seizures begin. What is not always clear from the literature are the details about which services the women attending ANC are receiving and whether or not they know what danger signs to look for in pregnancy. Attending ANC and receiving all essential ANC services is required for early detection of PE/E and to prevent the women with early signs of preeclampsia from worsening. 


\section{GAPS IN TREATMENT OF PE/E}

The literature very clearly supports the use of $\mathrm{MgSO}_{4}$ to manage eclamptic convulsions; $\mathrm{MgSO}_{4}$ is not the only weapon that we have against $\mathrm{PE} / \mathrm{E}$. If indicators of $\mathrm{PE} / \mathrm{E}$ are detected early in pregnancy, these symptoms can be managed using antihypertensive drugs before the condition escalates.

\section{Antihypertensives}

There is nothing in the literature that specifically reports on the effectiveness and safety of antihypertensives for pregnant women with high blood pressure; a few mention that as part of their treatment procedure, women were receiving antihypertensives to manage their high BP. Using antihypertensive drugs (labetalol, nifedipine, methyldopa, hydralazine) to manage high blood pressure in pregnant women is an important strategy to reduce the number of PE cases that escalate to eclampsia.

\section{Use of $\mathrm{MgSO}_{4}$}

Despite the abundance of evidence demonstrating the safety and effectiveness of $\mathrm{MgSO}_{4}$, its use has remained low, especially in developing countries where it, incidentally, is most needed. Low availability of $\mathrm{MgSO}_{4}$, lack of guidelines on its use (or unawareness of these guidelines), misinformation regarding who can administer the drug, poor knowledge of health workers on its use, fear of toxicity, little incentive for pharmaceutical companies to commercialize the drug (no profit to be made), ready availability of pre-packaged forms of less effective drugs (like diazepam), and lack of support for policy change all contribute to the underutilization of this safe and effective life-saving drug. Even if providers are trained to use $\mathrm{MgSO}_{4}$ and know how and when to use it, sometimes providers choose to use diazepam instead because they are more familiar with it since it was the recommended drug for PE/E in Nigeria for decades before $\mathrm{MgSO}_{4}$ was introduced (Ekele, 2009).

In addition to the relatively low use of $\mathrm{MgSO}_{4}$, there are no studies that demonstrate the lowest effective dose to manage $\mathrm{PE} / \mathrm{E}$. As described earlier in this paper, some researchers have started questioning and testing the dosage with preliminary results indicating that a reduced dose-either in amount delivered or timing of dosescan be as effective as the generally-accepted Pritchard regimen. 


\section{Conclusion}

Throughout the development of a pregnancy, there are many opportunities when PE/E can be prevented, detected and managed; based on the literature, certain gaps exist along this continuum of care. In order to have the most impact, we recommend a multi-level set of interventions that increase community awareness of symptoms of PE/E and ANC health seeking behavior, improve and expand provider skills and knowledge at multiple levels (including PHC) for detecting and treating high BP in pregnancy and PE/E throughout the developmental stages of pregnancy. Figure 5 visualizes the cycle of pregnancy and specific strategies that are currently thought to be the best practices to reduce maternal mortality related to PE/E; the blue stars correspond to opportunities that hold the most potential for significant reduction of incidence of eclampsia and subsequent death.

\section{FIGURE 5 Opportunities and strategies for preventing, detecting and treating PE/E}

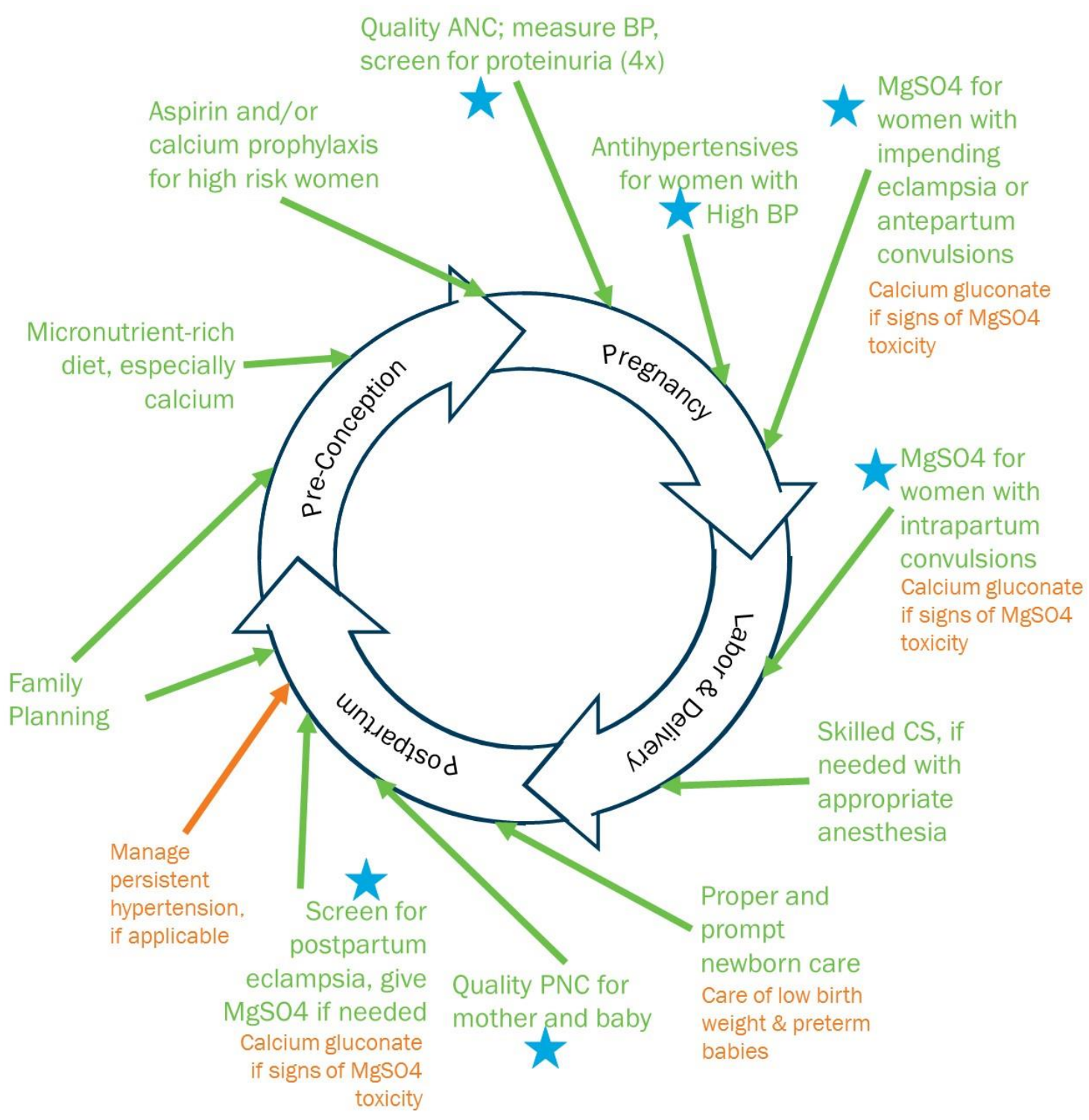

* orange text indicates adverse outcomes for which providers should monitor and be prepared to manage 


\section{RECOMIMENDATIONS}

\section{Develop common language and clear streamlined policies}

- Develop simple terminology and associated definitions for global use.

- Continued advocacy to hospital administrators and relevant policymakers to ensure that protocols are followed over time and that the necessary drugs and equipment are procured.

\section{Clarify and define management strategies and dosage}

- Determine the minimum effective dose for $\mathrm{MgSO}_{4}$.

- Create and distribute clear and concise guidelines and protocols for treating PE/E with antihypertensives and $\mathrm{MgSO}_{4}$.

- Assess the effectiveness and need of aspirin and/or calcium prophylaxis in Nigeria.

\section{Increase access to quality services}

- There should be training and re-training of healthcare providers on recognizing $\mathrm{PE} / \mathrm{E}$, managing high $\mathrm{BP}$ with antihypertensives, when and how to administer $\mathrm{MgSO}_{4}$, and how to monitor for and treat toxicity.

- Task-shifting can increase the workforce capable of providing life-saving services; PHC providers can and should be able to detect and provide initial treatment (antihypertensives and $\mathrm{MgSO}_{4}$ loading dose) for PE/E and monitor for toxicity.

\section{Engage Community}

- Increase community awareness of and access to antenatal care.

- Educate community members on the signs and symptoms of PE/E and when and where to seek treatment. 


\section{References}

Abdul, M., Nasir, U., Khan, N., \& Yusuf, M. (2013). Low-dose magnesium sulphate in the control of eclamptic fits: a randomized controlled trial. Archives of Gynecology and Obstetrics, 287(1), 43-6. Retrieved from http://link.springer.com/article/10.1007/s00404-012-2523-z

Abubakar, A., Abdullahi, R., HZ, J., Dauda, M. H., \& MA, P. (2009). Maternal Ethnicity and Severity of PreEclampsia in Northern Nigeria. Asian Journal of Medical Sciences, 1(3), 104-107.

Adeoye, I. A., Onayade, A. A., \& Fatusi, A. O. (2013). Incidence, determinants and perinatal outcomes of near miss maternal morbidity in lle-Ife Nigeria: a prospective case control study. BMC Pregnancy and Childbirth, 13, 93. http://doi.org/10.1186/1471-2393-13-93

Adeyemo, W., \& Rabiu, K. (2012). Orofacial injuries associated with eclampsia in patients presenting at a Nigerian Tertiary Hospital. ... of Obstetrics \& .... Retrieved from http://informahealthcare.com/doi/abs/10.3109/01443615.2011.613495

Adeyinka, D., Oladimeji, O., Adekanbi, T., Adeyinka, F., Falope, Y., \& Aimakhu, C. (2010). Outcome of adolescent pregnancies in southwestern Nigeria: A case control study. Journal of Maternal-Fetal and Neonatal Medicine, 23(8), 785-789. http://doi.org/http://dx.doi.org/10.3109/14767050903572166

Adokiye, E., \& Isreal, J. (2015). Factors influencing the prevalence of Preeclampsia-eclampsia in booked and unbooked patients: 3 years retrospective study in NDUTH, Okolobiri. World Journal of Medicine and Medical Science, 3(1), 1-14. Retrieved from http://www.wjmms.com/WJMMS_Vol. 3, No. 1, January 2015/Factors influencing.pdf

Afolayan, J. M., Nwachukwu, C. E., Esangbedo, E. S., Omu, P. O., Amadasun, F. E., \& Fadare, J. O. (2014). Evolving pattern of spinal anaesthesia in stable eclamptic patients undergoing caesarean section at University of Benin Teaching Hospital, Benin, Nigeria. Nigerian Journal of Medicine, 23(4), 288-295.

Airede, L., \& Ekele, B. (2003). Adolescent maternal mortality in Sokoto, Nigeria. Journal of Obstetrics and Gynaecology, 23(2), 163-165.

Akiibinu, M. O., Kolawole, T. O., Ekun, O. A., \& Akiibinu, S. O. (2013). Metabolic dysfunctions in Nigerian preeclamptics. Archives of Gynecology and Obstetrics, 288(5), 1021-1026. http://doi.org/10.1007/s00404-013-2854-4

Alabi, O. O., Olarunfemi, G., \& Onile, T. G. (2012). The trend in maternal mortality in an upgraded tertiary facility in North Central Nigeria. Nigerian Journal of Medicine : Journal of the National Association of Resident Doctors of Nigeria, 21(3), 282-289.

Altman, D., Carroli, G., Duley, L., Farrell, B., Moodley, J., Neilson, J., ... Magpie Trial Collaboration Group. (2002). Do women with pre-eclampsia, and their babies, benefit from magnesium sulphate? The Magpie Trial: a randomised placebo-controlled trial. The Lancet, 359(9321), 1877-90. Retrieved from http://www.sciencedirect.com/science/article/pii/S0140673602087780

Ameh, C. A., Ekechi, C. I., Tukur, J., \& J, A. C. E. C. T. (2012). Monitoring severe pre-eclampsia and eclampsia treatment in resource poor countries: skilled birth attendant perception of a new treatment and monitoring chart (LIVKAN chart). Maternal and Child Health Journal, 16(5), 941-946. http://doi.org/http://dx.doi.org/10.1007/s10995-011-0832-7

Anorlu, R. I., Iwuala, N. C., \& Odum, C. U. (2005). Risk factors for pre-eclampsia in Lagos, Nigeria. Australian and New Zealand Journal of Obstetrics and Gynaecology, 45(4), 278-282. http://doi.org/10.1111/j.1479-828X.2005.00411.x

AO, O. O. S. J. S.-O. (2004). The rise in caesarean birth rate in Sagamu, Nigeria: reflection of changes in obstetric practice. TT -. Journal of Obstetrics and Gynaecology, 24(4), 377-381.

Arinola, G., Arowojolu, A., Bamgboye, A., Akinwale, A., \& Adeniyi, A. (2006). Serum concentrations of immunoglobulins and acute phase proteins in Nigerian women with preeclampsia. Reproductive Biology, 6(3), 265-274. 
Attahir, A., Sufiyan, M. B., Salihu, A., \& Rabiu, a M. (2010). Association between Maternal Socio - economic Status, Polygamy and Risk of Pre - eclampsia in Rural Areas of Northern Nigeria. Journal of Family and Reproductive Health, 4(1), 47-52.

Chama, C., \& Geidam, A. (2013). A shortened versus standard matched postpartum magnesium sulphate regimen in the treatment of eclampsia: a randomised controlled trial: original article. African Journal of Reproductive Health, 17(3), 131-136.

Chigbu, C. O., Okezie, O. A., \& Odugu, B. U. (2009). Women in southern Nigeria with change in paternity do not have increased incidence of pre-eclampsia. Journal of Obstetrics and Gynaecology: The Journal of the Institute of Obstetrics and Gynaecology, 29(2), 94-97. http://doi.org/10.1080/01443610802660927

Ekele, B. A. (2009). Use of magnesium sulfate to manage pre-eclampsia and eclampsia in Nigeria: overcoming the odds. Annals of African Medicine, 8(2), 73-75. http://doi.org/10.4103/1596-3519.56231

Ekele, B., \& Ahmed, Y. (2004). Magnesium sulfate regimens for eclampsia. International Journal of Gynecology and Obstetrics, 87(2), 149-150.

Ekele, B., \& Badung, S. L. H. (2005). Is serum magnesium estimate necessary in patients with eclampsia on magnesium sulphate? African Journal of Reproductive Health, 9(1), 128-132. Retrieved from http://www.bioline.org.br/pdf?rh05015

Ekele, B., Bello, S., \& Adamu, A. (2007). Clusters of eclampsia in a Nigerian teaching hospital. International Journal of Gynecology and Obstetrics, 96(1), 62-66. Retrieved from http://www.sciencedirect.com/science/article/pii/S0020729206004905

Euser, A. G., \& Cipolla, M. J. (2009). Magnesium sulfate treatment for the prevention of eclampsia: A brief review. Stroke, 40(4), 1169-1175. http://doi.org/10.1161/STROKEAHA.108.527788.Magnesium

Ezugwu, E. C., Agu, P. U., Nwoke, M. O., \& Ezugwu, F. O. (2014). Reducing maternal deaths in a low resource setting in Nigeria. Nigerian Journal of Clinical Practice, 17(1), 62-66. http://doi.org/http://dx.doi.org/10.4103/1119-3077.122842

Familoni, O., Adefuye, P., Olunuga, T., Ayoola-Sotubo, O., \& Oritogun, S. (2008). QT Intervals and Outcome of Pregnancy in Patients with Eclampsia. Tropical Journal of Obstetrics and Gynaecology, 25(1).

Federal Ministry of Health Nigeria. (2010). Essential Medicines List (Fifth revision). Abuja.

Glew, R. H., Melah, G., El-Nafaty, A. I., Brandt, Y., Morris, D., \& VanderJagt, D. J. (2004). Plasma and urinary free amino acid concentrations in preeclamptic women in northern Nigeria. Clinica Chimica Acta; International Journal of Clinical Chemistry, 342(1-2), 179-185. http://doi.org/10.1016/j.cccn.2003.12.028

Guerrier, G., Oluyide, B., Keramarou, M., \& Grais, R. F. (2013). Factors associated with severe preeclampsia and eclampsia in Jahun, Nigeria. International Journal of Women's Health, 5(1), 509-513. http://doi.org/10.2147/IJWH.S47056

HA, O. C. U., Onyearugha, C. N., \& Ugboma, H. A. A. (2012). Fetal outcome of antepartum and intrapartum eclampsia in Aba, southeastern Nigeria. Tropical Doctor, 42(3), 129-132. http://doi.org/http://dx.doi.org/10.1258/td.2012.110206

Igberase, G., \& Ebeigbe, P. (2007). Maternal mortality in a rural referral hospital in the Niger Delta, Nigeria. JOURNAL OF OBSTETRICS AND GYNAECOLOGY, 27(3), 275-278. http://doi.org/10.1080/01443610701213687

Ikechebelu, J., \& Okoli, C. (2002). Review of eclampsia at the Nnamdi Azikiwe University teaching hospital, Nnewi (January 1996-December 2000). Journal of Obstetrics and Gynaecology, 22(3), 287-290. Retrieved from http://informahealthcare.com/doi/abs/10.1080/01443610220130580

Ishaku, S., Ahonsi, B., Tukur, J., \& Ayodeji, O. (2013). Attrition from care after the critical phase of severe preeclampsia and eclampsia : Insights from an intervention with magnesium sulphate in a primary care setting in northern Nigeria. Health, 5(9), 1461-1466.

Kullima, A. A., Kawuwa, M. B. M., Audu, B. M., Geidam, A. D., \& Mairiga, A. G. (2009). Trends in maternal 
mortality in a tertiary institution in Northern Nigeria. Annals of African Medicine, 8(4), 221-224. http://doi.org/http://dx.doi.org/10.4103/1596-3519.59575

Magee, L., Pels, A., Helewa, M., Rey, E., Von Dadelszen P, \& Canadian Hypertensive Disorders of Pregnancy (HDP) Working Group. (2015). The hypertensive disorders of pregnancy. Best Practice \& Research in Clinical Obstetrics \& Gynaecology, 29, 643-57. http://doi.org/10.1016/j.bpobgyn.2015.04.001

Makinde, O. (2009). HELLP syndrome: the experience at Ile-Ife, Nigeria. ... of Obstetrics \& .... Retrieved from http://informahealthcare.com/doi/abs/10.1080/01443610902753945

Makinde, O. N. (2011). The Contribution of Severe Pre-Eclampsia and Eclampsia to Perinatal Mortality in a Nigerian Teaching Hospital. In D. O. Ezechi (Ed.), Perinatal Mortality.

Ndukwe, K., Ugboko, V., Ogunlola, I., Orji, E., \& Makinde, O. (2004). Orofacial injuries in eclamptic Nigerians. African Journal of Reproductive Health, 8(3), 147-151.

Nkwocha, G. C., Anya, S. E., \& Anya, a E. (2006). Obstetric mortality in a Nigerian general hospital. Nigerian Journal of Medicine : Journal of the National Association of Resident Doctors of Nigeria, 15(1), 75-6. http://doi.org/10.4314/njm.v15i1.37122

NPC \& ICF International. (2014). Nigeria Demographic and Health Survey 2013. National Population Commission, 566. Retrieved from http://scholar.google.com/scholar?hl=en\&btnG=Search\&q=intitle:Nigeria+Demographic+and+Health+S urvey\#0 \nhttp://scholar.google.com/scholar?hl=en\&btnG=Search\&q=intitle:Nigeria+demographic+and+ health+survey+1999\#0

Nwagha, U. I., Nwachukwu, D., Dim, C., Ibekwe, P. C. P., \& Onyebuchi, A. (2010). Maternal mortality trend in South East Nigeria: less than a decade to the millennium developmental goals. Journal of Women's Health (2002), 19(2), 323-327. http://doi.org/10.1089/jwh.2008.1028

Nwobodo, E., \& Ahmed, Y. (2011). Maternal mortality associated with eclampsia in Sokoto, Nigeria. Orient Journal of Medicine2, 23.

Nwobodo, E. I., \& Panti, A. (2012). Adolescent maternal mortality in North-west Nigeria. West African Journal of Medicine, 31(4), 224-226.

Okafor, U. V, \& Ezegwui, H. U. (2010). Cesarean delivery in preeclampsia and seasonal variation in a tropical rainforest belt. Journal of Postgraduate Medicine, 56(1), 21-23. http://doi.org/10.4103/00223859.62431

Okafor, U. (2009). Maternal and perinatal outcome after caesarean delivery in preeclampsia or eclampsia in Enugu, Nigeria: four years on. International Journal of Obstetric Anesthesia. Retrieved from https://scholar.google.com/scholar?start=130\&q=Nigeria + preeclampsia, $+\mathrm{OR}+\% 22$ pre+eclampsia $\% 22+$ OR++pre-

eclampsia,+OR+eclampsia,+OR+\%22hellp+syndrome $\% 22+A N D+\% 22$ calcium+gluconate\%22+OR+\%22 magnesium+sulfate $\% 22+0 \mathrm{R}+\% 22$ magnesium+sulphate $\% 22+0 \mathrm{R}++$ phenytoin, $+\mathrm{OR}+$ chlor

Okafor, U., \& Efetie, E. (2006). Cerebrovascular accident with quadriplegia following postpartum eclampsia. ACTA ANAESTHESIOLOGICA SCANDINAVICA. Retrieved from http://onlinelibrary.wiley.com/doi/10.1111/j.1399-6576.2006.00920.x/full

Okafor, U., \& Okezie, O. (2005). Maternal and fetal outcome of anaesthesia of caesarean delivery in preeclampsia / eclampsia in Enugu, Nigeria: a retrospective observational study. International Journal of Obstetric Anesthesia, 14(2), 108-113. Retrieved from http://www.sciencedirect.com/science/article/pii/S0959289X04001864

Okereke, E., Ahonsi, B., Tukur, J., Ishaku, S. M., \& Oginni, A. B. (2012). Benefits of using magnesium sulphate (MgSO(4)) for eclampsia management and maternal mortality reduction: lessons from Kano State in Northern Nigeria. BMC Research Notes, 5, 421. http://doi.org/10.1186/1756-0500-5-421

Okonofua, F., Ogu, R., Fabamwo, A., Ujah, I., Chama, C., Archibong, E., ... Akuse, J. (2013). Training health workers for magnesium sulfate use reduces case fatality from eclampsia: Results from a multicenter trial. Acta Obstetricia et Gynecologica Scandinavica, 92, 716-720. Retrieved from http://onlinelibrary.wiley.com/doi/10.1111/aogs.12135/full 
Okusanya, B. O., Garba, K. D., \& Ibrahim, H. M. (2012). The efficacy of intramuscular loading dose of MgSO4 in severe pre-eclampsia/ eclampsia at a tertiary referral centre in Northwest Nigeria. The Nigerian Postgraduate Medical Journal, 19(2), 77-82.

Oladapo, O., Adetoro, O., Ekele, B., Chama, C., Etuk, S., Aboyeji, A., ... Gülmezoglu, A. (2015). When getting there is not enough: a nationwide cross-sectional study of 998 maternal deaths and 1451 near-misses in public tertiary hospitals in a low-income country. BJOG: An International Journal of Obstetrics \& Gynaecology, n/a-n/a. http://doi.org/10.1111/1471-0528.13450

Oladapo, O., Lamina, M., \& Fakoya, T. (2006). Maternal deaths in Sagamu in the new millennium: a facilitybased retrospective analysis. BMC Pregnancy and Childbirth, 6, 6.

Olayemi, O., Strobino, D., Adedapo, K., Aimakhu, C., Odukogbe, A.-T., \& Salako, B. (2010). Influence of previous abortions and new paternity on the risk of hypertension in nulliparous parturients in Ibadan: a cohort study. The Journal of Obstetrics and Gynaecology Research, 36(5), 965-969. http://doi.org/10.1111/j.1447-0756.2010.01268.x

Olayemi, O., Strobino, D., Aimakhu, C., Adedapo, K., Kehinde, A., Odukogbe, A.-T., \& Salako, B. (2010). Influence of duration of sexual cohabitation on the risk of hypertension in nulliparous parturients in Ibadan: A cohort study. The Australian \& New Zealand Journal of Obstetrics \& Gynaecology, 50(1), 4044. http://doi.org/10.1111/j.1479-828X.2009.01115.x

Olusanya, B. O. (2011). Perinatal outcomes of multiple births in southwest Nigeria. Journal of Health, Population, and Nutrition, 29(6), 639-647.

Olusanya, B. O., \& Solanke, O. A. (2012a). Maternal and neonatal profile of late-preterm survivors in a poorly resourced country. The Journal of Maternal-Fetal \& Neonatal Medicine: The Official Journal of the European Association of Perinatal Medicine, the Federation of Asia and Oceania Perinatal Societies, the International Society of Perinatal Obstetricians, 25(4), 346-352. http://doi.org/10.3109/14767058.2011.577471

Olusanya, B. O., \& Solanke, O. A. (2012b). Perinatal outcomes associated with maternal hypertensive disorders of pregnancy in a developing country. Hypertension in Pregnancy, 31(1), 120-130. http://doi.org/10.3109/10641955.2010.525280

Onah, H. (2002). Prognostic value of absolute versus relative rise of blood pressure in pregnancy. African Journal of Reproductive Health, 6(1), 32-40.

Onah, H., \& Iloabachie, G. (2002). Conservative management of early-onset pre-eclampsia and fetomaternal outcome in Nigerians. Journal of Obstetrics and Gynaecology, 22(4), 357-362. Retrieved from http://informahealthcare.com/doi/abs/10.1080/01443610220141524

Onakewhor, J. U. E., \& Gharoro, E. P. (2008). Changing trends in maternal mortality in a developing country. Nigerian Journal of Clinical Practice, 11(2), 111-120.

Onwuhafua, P. I., Onwuhafua, A., Adze, J., \& Mairami, Z. (2001). Eclampsia in Kaduna State of Nigeria--a proposal for a better outcome. Nigerian Journal of Medicine : Journal of the National Association of Resident Doctors of Nigeria, 10(2), 81-84.

Onyearugha, C. N., \& Ugboma, H. A. A. (2012a). Fetal outcome of antepartum and intrapartum eclampsia in Aba, southeastern Nigeria. Tropical Doctor, 42(3), 129-132. http://doi.org/10.1258/td.2012.110206

Onyearugha, C. N., \& Ugboma, H. A. A. (2012b). Fetal outcome of antepartum and intrapartum eclampsia in Aba, southeastern Nigeria. Tropical Doctor, 42(3), 129-132. http://doi.org/http://dx.doi.org/10.1258/td.2012.110206

Osinubi, A., Ajayi, G., \& Adegbola, O. (2009). Effect of normal and pre-eclamptic pregnancies on plasma cholinesterase in Nigerian women. African Journal of Endocrinology and Metabolism, 8(1), 1-3.

Osungbade, K., Oginni, S., Olumide, A., K, O., Oginni, S., \& Olumide, A. (2008). Content of antenatal care services in secondary health care facilities in Nigeria: implication for quality of maternal health care. INTERNATIONAL JOURNAL FOR QUALITY IN HEALTH CARE, 20(5), 346-351. http://doi.org/http://dx.doi.org/10.1093/intqhc/mznO26 
Owolabi, A., AO, F., Kuti, O., Adeyemi, A., Faturoti, S., \& Obiajuwa, P. (2008). Maternal complications and perinatal outcomes in booked and unbooked Nigerian mothers. Singapore Medical Journal, 49(7), 526531. Retrieved from http://smj.sma.org.sg/4907/4907a1.pdf

Ozumba, B. C., \& Anya, S. E. (2002). Maternal deaths associated with cesarean section in Enugu, Nigeria. International Journal of Gynaecology and Obstetrics: The Official Organ of the International Federation of Gynaecology and Obstetrics, 76(3), 307-309.

The World Health Organization. (2011). WHO recommendations for Prevention and treatment of pre-eclampsia and eclampsia. Geneva, Switzerland.

Tukur, J., Ahonsi, B., Ishaku, S. M., Araoyinbo, I., Okereke, E., \& Babatunde, A. O. (2013). Maternal and fetal outcomes after introduction of magnesium sulphate for treatment of preeclampsia and eclampsia in selected secondary facilities: a low-cost intervention. Maternal and Child Health Journal, 17(7), 11911198. http://doi.org/10.1007/s10995-012-1105-9

Tukur, J., Ogedengbe, C., Nwanchukwu, E., Araoyinbo, I. A., Yakasai, I. A., Adaji, S. E., \& Ajala, B. (2011). Introduction of an innovation for the reduction of maternal mortality in Kano State, northern Nigeria: a case study of magnesium sulphate. Tropical Doctor, 41(4), 197-200. http://doi.org/http://dx.doi.org/10.1258/td.2011.110034

Tukur, J., Umar, B. A., \& Rabi'u, A. (2007). Pattern of eclampsia in a tertiary health facility situated in a semirural town in northern Nigeria. Annals of African Medicine, 6(4), 164-167. Retrieved from http://www.bioline.org.br/pdf?am07037

Tukur, J., Umar, N. I., Khan, N., \& Musa, D. (2007). Comparison of emergency caesarean section to misoprostol induction for the delivery of antepartum eclamptic patients: a pilot study. Nigerian Journal of Medicine : Journal of the National Association of Resident Doctors of Nigeria, 16(4), 364-367.

Ugwu, E. O. V, Dim, C. C., Okonkwo, C. D., \& Nwankwo, T. O. (2011). Maternal and perinatal outcome of severe pre-eclampsia in Enugu, Nigeria after introduction of Magnesium sulfate. Nigerian Journal of Clinical Practice, 14(4), 418-421. http://doi.org/10.4103/1119-3077.91747

Waziri-Erameh, M., Omoti, A., \& Edema, O. (2003). Bilateral Total Loss of Vision Following Eclampsia: A Case Report. African Journal of Reproductive .... Retrieved from http://www.jstor.org/stable/3583218

Yeager, B., \& Patel, S. (2012). Medicines for Maternal Health; Key Data and Findings. 


\section{Appendix I:}

\section{SEARCH QUERIES FOR BIBLIOGRAPHIC DATABASE SEARCHES}

\begin{tabular}{|c|c|c|c|c|c|c|}
\hline Humans* & AND & Pregnancy* & AND & Nigeria* & AND & $\begin{array}{l}\text { Seizures* OR } \\
\text { Hypertension* OR } \\
\text { “Hypertensive Disorders" OR } \\
\text { Pregnancy-induced hypertension*+ OR } \\
\text { Proteinuria* OR } \\
\text { "blood pressure"* OR } \\
\text { Anticonvulsants* OR } \\
\text { “magnesium sulfate" OR } \\
\text { “Magnesium Sulphate" OR } \\
\text { Aspirin* OR } \\
\text { "calcium supplementation" OR } \\
\text { Complications }\end{array}$ \\
\hline Humans* & AND & $\begin{array}{l}\text { Pre } \\
\text { eclampsia*† } \\
\text { OR eclampsia } \\
\text { OR } \\
\text { HELLP } \\
\text { Syndrome }\end{array}$ & AND & Nigeria* & AND & $\begin{array}{l}\text { “calcium gluconate"* OR } \\
\text { “Magnesium sulfate” OR } \\
\text { “magnesium sulphate" OR } \\
\text { Phenytoin* OR } \\
\text { Chlorpromazine* OR } \\
\text { Meripidine* OR } \\
\text { Diazepam }\end{array}$ \\
\hline Humans* & AND & $\begin{array}{l}\text { Pre } \\
\text { eclampsia*† } \\
\text { OR eclampsia } \\
\text { OR } \\
\text { HELLP } \\
\text { Syndrome }\end{array}$ & AND & Nigeria* & AND & $\begin{array}{l}\text { “early diagnosis"* OR } \\
\text { Treatment OR } \\
\text { “prenatal diagnosis"* OR } \\
\text { “health personnel”* OR } \\
\text { "prenatal care"* OR } \\
\text { "postnatal care" OR } \\
\text { "blood pressure"* OR } \\
\text { “Aspirin"* OR } \\
\text { "aspirin prophylaxis" }\end{array}$ \\
\hline Humans* & AND & $\begin{array}{l}\text { Pre } \\
\text { eclampsia*† } \\
\text { OR eclampsia } \\
\text { OR } \\
\text { HELLP } \\
\text { Syndrome }\end{array}$ & AND & Nigeria* & AND & $\begin{array}{l}\text { “maternal death"* OR } \\
\text { “maternal mortality”* OR } \\
\text { “disease management”* OR } \\
\text { Treatment OR } \\
\text { “near miss" OR } \\
\text { “induced labor” }\end{array}$ \\
\hline
\end{tabular}

*denotes use of MeSH terms, when available

†MeSH terms for "pre eclampsia" include alternate spellings, when MeSH terms were unavailable in search, alternative were included and linked using 'OR' “Preeclampsia OR pre-eclampsia OR pre eclampsia” 


\section{Appendix II:}

\section{PAPERS REMOVED DURING PHASE TWO AND EXCLUSION REASON}

\begin{tabular}{|c|c|c|}
\hline Citation & Reason & Notes \\
\hline $\begin{array}{l}\text { Abdul, M. A., Odogwu, K., \& Madugu, N. (2011). Gross vulva eodema complicating severe pre- } \\
\text { eclampsia/eclampsia: a case series. Nigerian Journal of Medicine: Journal of the National } \\
\text { Association of Resident Doctors of Nigeria, 20(3), 380-382. }\end{array}$ & No Full Text & Obscure Journal, couldn't acquire full text \\
\hline $\begin{array}{l}\text { Adamu, A., Ekele, B., \& Ahmed, Y. (2012). W219 PREGNANCY OUTCOME IN } 1027 \text { CONSECUTIVE WOMEN } \\
\text { WITH ECLAMPSIA. African Journal of Gynecology \& Obstetrics, 119(S3), S531-S867. }\end{array}$ & No Full Text & $\begin{array}{l}\text { Abstract published in "poster presentations" supplement of African } \\
\text { Journal of Gynecology \& Obstetrics. *Full paper version of this abstract } \\
\text { was separately identified and included in the review. }\end{array}$ \\
\hline $\begin{array}{l}\text { Adewole, I., Oladokun, A., Okewole, A., Omigbodun, A., Afolabi, A., Ekele, B., Obed, Y. (2000). Magnesium } \\
\text { sulphate for treatment of eclampsia: the Nigerian experience. African Journal of Medicine and } \\
\text { Medical Sciences, 29(3-4), 239-241. }\end{array}$ & No Full Text & Could not locate full text \\
\hline $\begin{array}{l}\text { Atiba, A. S., Abbiyesuku, F. M., Adekanle, D. A., Oparinde, D. P., Ajose, O. A., \& Niran-Atiba, T. A. (2014). } \\
\text { Malondialdehyde and antioxidant enzymes in second and third trimesters of pre-eclamptic } \\
\text { Nigerian women. The Nigerian Postgraduate Medical Journal, 21(2), 150-154. }\end{array}$ & No Full Text & Local journal, unable to locate full text \\
\hline $\begin{array}{l}\text { Awoleke, J. O., Ajayi, G. O., \& Adegbola, O. (2012). Prevalence of Chlamydophila pneumoniae antibodies } \\
\text { in women with pre-eclampsia in Lagos, Nigeria. West African Journal of Medicine, 31(4), 253- } \\
258 .\end{array}$ & No Full Text & Could not locate full text \\
\hline $\begin{array}{l}\text { Brabin, B. J., \& Johnson, P. M. (2005). Placental malaria and pre-eclampsia through the looking glass } \\
\text { backwards? Journal of Reproductive Immunology, } 65(1), 1-15 .\end{array}$ & Not Nigeria & Not enough focus on Nigeria or Nigeria-specific data \\
\hline $\begin{array}{l}\text { Durojaye, E. (2009). }\{194\} \text { Human rights implications of maternal mortality. International Journal of } \\
\text { Gynecology \& Obstetrics, 107, Suppl(0), S24 - }\end{array}$ & No Full Text & $\begin{array}{l}\text { Abstract published in "invited presentations" supplement of International } \\
\text { Journal of Gynecology \& Obstetrics. }\end{array}$ \\
\hline $\begin{array}{l}\text { Egbodo, C. O., \& Oyebode, T. (2012). W248 ECLAMPSIA, PATIENT CHARACTERISTICS AND CONTRIBUTION } \\
\text { TO MATERNAL AND PERINATAL MORBIDITY AND MORTALITY: A THREE YEAR REVIEW AT THE } \\
\text { JOS UNIVERSITY TEACHING HOSPITAL, NIGERIA. International Journal of Gynecology \& } \\
\text { Obstetrics, 119, Suppl(0), S785 - S786. }\end{array}$ & No Full Text & $\begin{array}{l}\text { Abstract published in "poster presentations" supplement of International } \\
\text { Journal of Gynecology \& Obstetrics. }\end{array}$ \\
\hline $\begin{array}{l}\text { Ezugwu, E., Onah, H., Ezugwu, F., \& Okafor, I. (2009). \{0282\} Low birth weight babies at a tertiary hospital } \\
\text { in Enugu, South East Nigeria. International Journal of Gynecology \& Obstetrics, 107, Suppl(0), } \\
\text { S173 -. }\end{array}$ & No Full Text & $\begin{array}{l}\text { Abstract published in 'Abstracts of XIX FIGO World Congress of Gynecology } \\
\text { and Obstetrics' }\end{array}$ \\
\hline $\begin{array}{l}\text { Fawole, A. O., Sotiloye, O. S., Oladimeji, A. O., Alao, M. O., Hunyinbo, K. I., Sadoh, E. A., \& Otolorin, E. O. } \\
\text { (2008). Antenatal cardiotocography: experience in a Nigerian tertiary hospital. The Nigerian } \\
\text { Postgraduate Medical Journal, 15(1), 19-23. }\end{array}$ & $\begin{array}{l}\text { Not related to } \\
\mathrm{PE} / \mathrm{E}\end{array}$ & \\
\hline FIGO. (2010). Successful advocacy for Government provision of MgSO4 in Nigeria. & Grey Literature & \\
\hline $\begin{array}{c}\text { Fujioka, A., \& Smith, J. (2011). Prevention and Management of Postpartum Hemorrhage and Pre- } \\
\text { Eclampsia/Eclampsia: National Programs in Selected USAID Program-Supported Countries. }\end{array}$ & Grey Literature & \\
\hline
\end{tabular}




\begin{tabular}{|c|c|c|}
\hline Citation & Reason & Notes \\
\hline $\begin{array}{l}\text { George, I., Jeremiah, I., \& John, C. (2009). \{0340\} Perinatal morbidity and mortality associated with } \\
\text { eclampsia in a Nigerian tertiary hospital. International Journal of Gynecology \& Obstetrics, } \\
\text { 107, Suppl(0), S189 -. }\end{array}$ & No Full Text & Abstract for oral presentation published in supplement \\
\hline $\begin{array}{l}\text { Gordon, R., Magee, L., \& Payne, B. (2014). Magnesium sulphate for the management of preeclampsia } \\
\text { and eclampsia in low and middle income countries: a systematic review of tested dosing } \\
\text { regimens. Journal of Obstetrics and Gynaecology Canada, 36(2), 154-163. }\end{array}$ & Not Nigeria & Not enough focus on Nigeria or Nigeria-specific data \\
\hline $\begin{array}{l}\text { Ishaku, S. M., Ahonsi, B., Tukur, J., \& Oginni, A. B. (2012). O328 TASK-SHIFTING USING MAGNESIUM } \\
\text { SULPHATE (MGSO4) TO TREAT SEVERE PRE-ECLAMPSIA AND ECLAMPSIA IN PRIMARY CARE } \\
\text { SETIINGS, IN KANO STATE, NIGERIA. International Journal of Gynecology \& Obstetrics, 119, } \\
\text { S376. }\end{array}$ & No Full Text & Abstract for oral presentation published in supplement \\
\hline $\begin{array}{l}\text { Itam, I. H., \& Ekabua, J. E. (2001). A Review of Pregnancy Outcome in Women with Eclampsia at the } \\
\text { University of Calabar Teaching Hospital, Calabar. Tropical Journal of Obstetrics and } \\
\text { Gynaecology, 18(2), 66-68. }\end{array}$ & No Full Text & Local journal, unable to locate full text or contact authors \\
\hline $\begin{array}{l}\text { Jeremiah, I., \& Fiebai, P. (2009). \{0419\} The unbooked status: a major contributor to maternal morbidity } \\
\text { and mortality. International Journal of Gynecology \& Obstetrics, } 107 \text {, Suppl(0). S211 -. }\end{array}$ & No Full Text & Abstract for oral presentation published in supplement \\
\hline $\begin{array}{l}\text { Familoni, O., Adefuye, P., Olunuga, T., Ayoola-Sotubo, O., \& Oritogun, S. (2008). QT Intervals and Outcome } \\
\text { of Pregnancy in Patients with Eclampsia. Tropical Journal of Obstetrics and Gynaecology, } \\
\text { 25(1). }\end{array}$ & No Full Text & $\begin{array}{l}\text { Unavailable online, attempted to contact author, could not acquire full } \\
\text { text. }\end{array}$ \\
\hline $\begin{array}{l}\text { Nwagha, U. l., Ejezie, F. E., \& lyare, E. E. (2009). Evaluation of serum uric acid levels in normal pregnant } \\
\text { Nigerian women. Nigerian Journal of Clinical Practice, } 12(1), 83-86 \text {. }\end{array}$ & No Full Text & Unable to access article online, attempted to contact author. \\
\hline $\begin{array}{l}\text { Obiechina, N. J., \& Udigwe, G. (2004). Pattern of Eclampsia in Onitsha, Nigeria. Orient Journal of Medicine, } \\
\text { 16(1), 16-20. }\end{array}$ & No Full Text & No response from author \\
\hline $\begin{array}{l}\text { Okafor, C., Follen, M., \& Adewole, I. (2007). Opportunities to improve health systems in Africa. A } \\
\text { comparative overview of healthcare challenges for stakeholders and strategic planners. } \\
\text { Gynecologic Oncology, } 107(1 \text {, Supplement), S86 - S93. }\end{array}$ & $\begin{array}{l}\text { Not related to } \\
\mathrm{PE} / \mathrm{E}\end{array}$ & \\
\hline $\begin{array}{l}\text { Okafor, U. V, Efetie, E. R., Nwoke, O., Okezie, O., \& Umeh, U. (2012). Anaesthetic and obstetric challenges } \\
\text { of morbid obesity in caesarean deliveries-a study in South-eastern Nigeria. African Health } \\
\text { Sciences, 12(1), 54-57. }\end{array}$ & $\begin{array}{l}\text { Not related to } \\
\mathrm{PE} / \mathrm{E}\end{array}$ & \\
\hline $\begin{array}{l}\text { Ola, Rotimi E, OT Odeneye, and Olalekan O Abudu. "Eclampsia: A Randomized Double Blind Trial of } \\
\text { Magnesium Sulphate and Diazepam in Lagos, Nigeria." Tropical Journal of Obstetrics and } \\
\text { Gynaecology, } 21.2 \text { (2004). }\end{array}$ & No Full Text & Obscure Journal, couldn't acquire full text \\
\hline $\begin{array}{l}\text { Oladokun, A., Okewole, A. I., Adewole, I. F., \& Babarinsa, I. A. (2000). Evaluation of cases of eclampsia in } \\
\text { the University College Hospital, Ibadan over a } 10 \text { year period. West African Journal of Medicine, } \\
\text { 19(3), 192-194. }\end{array}$ & No Full Text & Unable to acquire full text \\
\hline $\begin{array}{l}\text { Onah, H. E., \& Okaro, J. M. (2001). Caesarean Section in the Delivery of Nigerian Eclamptics. Tropical } \\
\text { Journal of Obstetrics and Gynaecology, 18(1). }\end{array}$ & No Full Text & Obscure Journal, couldn't acquire full text \\
\hline
\end{tabular}




\begin{tabular}{|c|c|c|}
\hline Citation & Reason & Notes \\
\hline $\begin{array}{l}\text { Onwuhafua, P. I., \& Oguntayo, A. (2006). Perinatal mortality associated with eclampsia in Kaduna, } \\
\text { Northern Nigeria. Nigerian Journal of Medicine : Journal of the National Association of Resident } \\
\text { Doctors of Nigeria, 15(4), 397-400. }\end{array}$ & No Full Text & Unable to acquire full text \\
\hline $\begin{array}{l}\text { Orazulike, N., Fiebai, P., \& Uzoigwe, S. (2009). \{0725\} The effect of antenatal care on maternal mortality } \\
\text { in Port Harcourt, Nigeria. International Journal of Gynecology \& Obstetrics, 107, Suppl(0), } \\
\text { S301 -. }\end{array}$ & No Full Text & Abstract for oral presentation published in supplement \\
\hline $\begin{array}{l}\text { Souza, J. P., Gülmezoglu, A. M., Vogel, J., Carroli, G., Lumbiganon, P., Qureshi, Z., ... Say, L. (2013). Moving } \\
\text { beyond essential interventions for reduction of maternal mortality (the }\{\text { WHO\} Multicountry } \\
\text { Survey on Maternal and Newborn Health): a cross-sectional study. The Lancet, 381(9879), } \\
\text { 1747-1755. }\end{array}$ & Not Nigeria & Not enough focus on Nigeria or Nigeria-specific data \\
\hline $\begin{array}{l}\text { Tukur, J., \& Muhammad, Z. (2010). Management of eclampsia at AKTH: before and after magnesium } \\
\text { sulphate. Nigerian Journal of Medicine, 19(1), 104-7. }\end{array}$ & No Full Text & Journal not available online prior to 2011 \\
\hline $\begin{array}{l}\text { Tukur, J., Babatunde, A., Salisu, I., \& Ayodeji, O. (2012). I369 EXPANDING THE USE OF MAGNESIUM } \\
\text { SULPHATE IN NIGERIA. International Journal of Gynecology \& Obstetrics, 119S3, S161-S260. }\end{array}$ & No Full Text & Abstract for oral presentation published in supplement \\
\hline $\begin{array}{l}\text { Uzoigwe, S. A., \& John, C. T. (2004). Maternal mortality in the University of Port Harcourt Teaching } \\
\text { Hospital, Port Harcourt in the last year before the new millennium. Nigerian Journal of } \\
\text { Medicine : Journal of the National Association of Resident Doctors of Nigeria, 13(1), 32-35. }\end{array}$ & No Full Text & Unable to acquire full text \\
\hline $\begin{array}{l}\text { van Lonkhuijzen, L., Stekelenburg, J., \& van Roosmalen, J. (2012). Maternity waiting facilities for } \\
\text { improving maternal and neonatal outcome in low-resource countries. The Cochrane Database } \\
\text { of Systematic Reviews, 10, CD006759. }\end{array}$ & $\begin{array}{l}\text { Not related to } \\
\mathrm{PE} / \mathrm{E}\end{array}$ & \\
\hline $\begin{array}{l}\text { von Dadelszen, P., Sawchuck, D., Justus Hofmeyr, G., Magee, L. A., Bracken, H., Mathai, M., ... Roberts, } \\
\text { J. M. (2013). PRE-EMPT (PRE-eclampsia-Eclampsia Monitoring, Prevention and Treatment): A } \\
\text { low and middle income country initiative to reduce the global burden of maternal, fetal and } \\
\text { infant death and disease related to pre-eclampsia. Pregnancy Hypertension: An International } \\
\text { Journal of Women's Cardiovascular Health, 3(4), 199-202. }\end{array}$ & Not Nigeria & $\begin{array}{l}\text { Not enough focus on Nigeria or Nigeria-specific data; Nigeria is part of the } \\
\text { PRE-EMPT project, but this paper merely included Nigeria in a list of } \\
\text { countries. }\end{array}$ \\
\hline $\begin{array}{l}\text { Wahab, K. W., Sanya, E. O., Ademiluyi, B. A., \& Bello, A. H. (2014). Posterior reversible encephalopathy } \\
\text { syndrome complicating postpartum eclampsia in a Nigerian: case report. The Nigerian } \\
\text { Postgraduate Medical Journal, 21(3), 266-268. }\end{array}$ & No Full Text & Unable to acquire full text \\
\hline $\begin{array}{l}\text { Watila, M., Omeiza, B., \& Kwari, S. (2015). Seizure occurrence, pregnancy outcome among women with } \\
\text { active convulsive epilepsy; one year prospective study. Seizure. }\end{array}$ & $\begin{array}{l}\text { Not related to } \\
\mathrm{PE} / \mathrm{E}\end{array}$ & $\begin{array}{l}\text { Related to seizure associated with epilepsy; eclamptic patients were } \\
\text { excluded from the study }\end{array}$ \\
\hline $\begin{array}{l}\text { Yakasai, I., Dikko, B., Sunday, A., \& Tukur, J. (2009). 01018 Free maternity services in Kano State } \\
\text { Nigeria-Use of magnesium sulphate as key to reduction of maternal mortality. International } \\
\text { Journal of Gynecology }\end{array}$ & No Full Text & Abstract for oral presentation, published in supplement \\
\hline Yeager, B., \& Patel, S. (2012). Medicines for Maternal Health; Key Data and Findings. & Grey Literature & \\
\hline
\end{tabular}




\section{Appendix III:}

SUMMARY TABLES OF 19 INTERVENTIONS TO IMPROVE PREVENTION/TREATMENT OF PE/E

\begin{tabular}{|c|c|c|c|c|c|}
\hline Citation & Study Design & $\begin{array}{l}\text { Location, } \\
\text { Timeframe, and } \\
\text { Sample size }\end{array}$ & $\begin{array}{l}\text { Prevalence } \\
\text { / } \\
\text { Incidence/ } \\
\text { CFR }\end{array}$ & Brief summary of methods/intervention & $\begin{array}{l}\text { Main findings/ limitations } \\
\text { Conclusions/ } \\
\text { Recommendations }\end{array}$ \\
\hline $\begin{array}{l}\text { Abdul, M., Nasir, U., Khan, } \\
\text { N., \& Yusuf, M. (2013). } \\
\text { Low-dose magnesium } \\
\text { sulphate in the control of } \\
\text { eclamptic fits: a } \\
\text { randomized controlled } \\
\text { trial. Archives of } \\
\text { Gynecology and Obstetrics, } \\
287(1), 43-6 .\end{array}$ & $\begin{array}{l}\text { Randomized } \\
\text { Controlled } \\
\text { Trial }\end{array}$ & $\begin{array}{l}\text { Labour Unit, } \\
\text { Obstetrics and } \\
\text { Gynecology Federal } \\
\text { Medical Centre, } \\
\text { Azare, north-eastern } \\
\text { Nigeria } \\
\text { January to August } \\
2008 \\
72 \text { patients } \\
\text { recruited, } 39 \\
\text { randomized into low- } \\
\text { dose group, } 33 \text { were } \\
\text { in standard regimen } \\
\text { group }\end{array}$ & $\begin{array}{l}\text { Prevalence } \\
\text { rate of } \\
\text { eclampsia } \\
=4.2 \% \\
\text { CFR }=5.5 \%\end{array}$ & $\begin{array}{l}\text { Standard dose: } 14 \mathrm{~g} \text { loading dose of MgSO4 } \\
\text { ( } 4 \mathrm{~g} \text { IV, } 10 \mathrm{~g} \text { IM) followed by IM maintenance } \\
\text { dose of } 5 \mathrm{~g} \text { every four hours } \\
\text { Low dose: } 9 \mathrm{~g} \text { loading dose of Mg SO4 (4g IV, } \\
5 \mathrm{~g} \text { IM) followed by IM } 2.5 \mathrm{~g} \text { every four hours }\end{array}$ & $\begin{array}{l}\text { - } \quad \text { Primigravidas: } 57 \% \text { of cases. } \\
\text { - } 44 \% \text { intrapartum, } 26 \% \text { antepartum, and } 15 \% \text { postpartum } \\
\text { eclampsia. } \\
\text { Recurrent convulsion rate did not differ between the study } \\
\text { groups. } \\
\text { There were more cesarean deliveries and perinatal deaths in } \\
\text { the low-dose group, but the difference was not statistically } \\
\text { significant. } \\
\text { Other maternal complications, including mortality, were not } \\
\text { significantly different between the groups. } \\
\text { Limitations: small sample size and the study was not } \\
\text { blinded. } \\
\text { Conclusions: more studies needed to determine whether a } \\
\text { low-dose regimen of MgSO } 4 \text { should be standardized. }\end{array}$ \\
\hline $\begin{array}{l}\text { Afolayan, J. M., } \\
\text { Nwachukwu, C. E., } \\
\text { Esangbedo, E. S., Omu, P. } \\
\text { O., Amadasun, F. E., \& } \\
\text { Fadare, J. O. (2014). } \\
\text { Evolving pattern of spinal } \\
\text { anaesthesia in stable } \\
\text { eclamptic patients } \\
\text { undergoing caesarean } \\
\text { section at University of } \\
\text { Benin Teaching Hospital, } \\
\text { Benin, Nigeria. Nigerian }\end{array}$ & $\begin{array}{l}\text { Retrospective } \\
\text { case review }\end{array}$ & $\begin{array}{l}\text { University of Benin } \\
\text { Teaching Hospital, } \\
\text { Benin City, Nigeria } \\
\text { January 1, 2011- } \\
\text { December 31, 2012 } \\
99 \text { cases of } \\
\text { eclampsia }\end{array}$ & $\begin{array}{l}\text { Incidence } \\
\text { of } \\
\text { eclampsia: } \\
170 \text { in } \\
10,000= \\
1.7 \%\end{array}$ & $\begin{array}{l}\text { Patients' case notes were reviewed; clinical } \\
\text { and demographic data was extracted and } \\
\text { analyzed. }\end{array}$ & $\begin{array}{l}\text { - } 58.59 \% \text { antepartum, } 29.29 \% \text { intrapartum, } 12.12 \% \\
\text { postpartum eclampsia } \\
68.73 \% \text { of cases were nulliparous and } 84.1 \% \text { did not receive } \\
\text { ANC at the hospital } \\
\text { - } 82 \text { underwent caesarean section; } 13.4 \% \text { of whom were }<20 \\
\text { years old, 39\% were between } 25-29 \text { years old, and } 52.4 \% \\
\text { were } 30+\text { years old } \\
\text { Of patients who underwent c/s, } 65 \text { ( } 79.3 \%) \text { had spinal } \\
\text { anaesthesia and } 17 \text { (20.7\%) had general anaesthesia. } \\
\text { This study concludes that maternal and perinatal survival is } \\
\text { better when the patient undergoes spinal anaesthesia than } \\
\text { those who had general anaesthesia. }\end{array}$ \\
\hline
\end{tabular}




\begin{tabular}{|c|c|c|c|c|c|}
\hline Citation & Study Design & $\begin{array}{l}\text { Location, } \\
\text { Timeframe, and } \\
\text { Sample size }\end{array}$ & $\begin{array}{l}\text { Prevalence } \\
/ \\
\text { Incidence/ } \\
\text { CFR }\end{array}$ & Brief summary of methods/intervention & $\begin{array}{l}\text { Main findings/ limitations } \\
\text { Conclusions/ } \\
\text { Recommendations }\end{array}$ \\
\hline \multicolumn{6}{|l|}{$\begin{array}{l}\text { Journal of Medicine, 23(4), } \\
288-295 .\end{array}$} \\
\hline $\begin{array}{l}\text { Altman, D., Carroli, G., } \\
\text { Duley, L., Farrell, B., } \\
\text { Moodley, J., Neilson, J., ... } \\
\text { Magpie Trial Collaboration } \\
\text { Group. (2002). Do women } \\
\text { with pre-eclampsia, and } \\
\text { their babies, benefit from } \\
\text { magnesium sulphate? The } \\
\text { Magpie Trial: a randomised } \\
\text { placebo-controlled trial. } \\
\text { The Lancet, 359(9321), } \\
\text { 1877-90. }\end{array}$ & $\begin{array}{l}\text { Randomized } \\
\text { placebo- } \\
\text { controlled } \\
\text { trial } \\
\text { Magpie Trial }\end{array}$ & $\begin{array}{l}\text { Was conducted in } \\
33 \text { countries, } \\
\text { including Nigeria. } \\
10,141 \text { women }\end{array}$ & & $\begin{array}{l}\text { 10, } 141 \text { women who had not given birth or } \\
\text { were }<24 \mathrm{~h} \text { postpartum, blood pressure } \\
140 / 90 \mathrm{mmHg} \text { or more and proteinuria of } \\
1+(30 \mathrm{mg} / \mathrm{dL}) \text { or more. } \\
\text { Randomized to: } \\
\text { Magnesium sulphate }(\mathrm{n}=5071) \text { or placebo } \\
(\mathrm{n}=5070)\end{array}$ & $\begin{array}{l}\text { While this study does not report findings specific to Nigeria, } \\
\text { it is listed here as it was the Magpie Trial that definitively } \\
\text { demonstrated the safety and effectiveness of MgSO4 for the } \\
\text { management of severe PE/E. } \\
\text { This trial found that MgSO4 reduces the risk of eclampsia } \\
\text { (and probably risk of maternal death) by half with no } \\
\text { substantive harmful effects for mother or baby. }\end{array}$ \\
\hline $\begin{array}{l}\text { Ameh, C. A., Ekechi, C. I., } \\
\text { Tukur, J., \& J, A. C. E. C. T. } \\
\text { (2012). Monitoring severe } \\
\text { pre-eclampsia and } \\
\text { eclampsia treatment in } \\
\text { resource poor countries: } \\
\text { skilled birth attendant } \\
\text { perception of a new } \\
\text { treatment and monitoring } \\
\text { chart (LIVKAN chart). } \\
\text { Maternal and Child Health } \\
\text { Journal, 16(5), 941-946. }\end{array}$ & $\begin{array}{l}\text { Cross- } \\
\text { sectional }\end{array}$ & $\begin{array}{l}\text { Katsina, Nigeria } \\
118 \text { participants } \\
\text { (skilled birth } \\
\text { attendants) over five } \\
\text { workshops in } 2010\end{array}$ & N/A & $\begin{array}{l}\text { LIVKAN chart was developed and providers } \\
\text { were trained on its use. Participating } \\
\text { providers were interviewed using a semi- } \\
\text { structured questionnaire to assess the } \\
\text { usefulness in the chart and assess the } \\
\text { quality of care for severe PE/E. }\end{array}$ & $\begin{array}{l}\text { - The goal was to assess the usefulness of the treatment } \\
\text { monitoring tool (LIVKAN chart) in improving quality of care } \\
\text { for severe PE/E using questionnaires } \\
\text { 98\% reported that the LIVKAN chart was better than existing } \\
\text { monitoring system and would be useful for improving care. } \\
73 \% \text { said the chart would be useful at lower levels and } \\
\text { improve documentation of referral. } \\
\text { - Some challenges to using the LIVKAN chart were high } \\
\text { workload ( } 45 \% \text { ) and irregular supply of blank charts ( } 53 \% \text { ). } \\
\text { The chart combines monitoring and treatment guidelines } \\
\text { (anticonvulsant, anti-hypertensive, IV fluids, calcium } \\
\text { gluconate and delivery) and allows for } 24 \mathrm{~h} \text { of monitoring } \\
\text { using fewer pages. }\end{array}$ \\
\hline $\begin{array}{l}\text { Chama, C., \& Geidam, A. } \\
\text { (2013). A shortened versus } \\
\text { standard matched } \\
\text { postpartum magnesium } \\
\text { sulphate regimen in the } \\
\text { treatment of eclampsia: a } \\
\text { randomised controlled } \\
\text { trial: original article. African } \\
\text { Journal of Reproductive } \\
\text { Health, } 17(3), 131-136 .\end{array}$ & $\begin{array}{l}\text { Randomised } \\
\text { Controlled } \\
\text { Trial }\end{array}$ & $\begin{array}{l}\text { Labour ward of } \\
\text { University of } \\
\text { Maiduguri Teaching } \\
\text { Hospital } \\
\text { January and June } \\
2011 \\
98 \text { eclamptic } \\
\text { mothers }\end{array}$ & $\begin{array}{l}\text { Incidence } \\
6.41 \% \\
(141 \text { out of } \\
2,201 \\
\text { deliveries) }\end{array}$ & $\begin{array}{l}\text { Eclamptic mothers were randomized and } \\
\text { received either the standard or shortened } \\
\text { postpartum regimen. Fetomaternal } \\
\text { outcomes were measured and compared. }\end{array}$ & $\begin{array}{l}\text { - } 21 \text { of the } 141 \text { had previously received anticonvulsants } \\
\text { (mainly diazepam) from referring health facilities and } 8 \text { had } \\
\text { other complications and were excluded } \\
\text { The remaining } 112 \text { participants were randomized to receive } \\
\text { either the standard Pritchard regimen of } \mathrm{MgSO}_{4} \text { or a } \\
\text { shortened postpartum course: two doses of } \mathrm{IM} \mathrm{MgSO}_{4} \text { are } \\
\text { given four hours apart. ( } 14 \text { had incomplete information and } \\
98 \text { were included in the analysis) } \\
\text { - } \quad \text { Primary outcome measure was recurrence of fits } \\
\text { - The shortened course was found to be as effective as } \\
\text { Pritchard for the management of eclampsia }\end{array}$ \\
\hline
\end{tabular}




\begin{tabular}{|c|c|c|c|c|c|}
\hline Citation & Study Design & $\begin{array}{l}\text { Location, } \\
\text { Timeframe, and } \\
\text { Sample size }\end{array}$ & $\begin{array}{l}\text { Prevalence } \\
/ \\
\text { Incidence/ } \\
\text { CFR }\end{array}$ & Brief summary of methods/intervention & $\begin{array}{l}\text { Main findings/ limitations } \\
\text { Conclusions/ } \\
\text { Recommendations }\end{array}$ \\
\hline $\begin{array}{l}\text { Ekele, B., \& Ahmed, Y. } \\
\text { (2004). Magnesium sulfate } \\
\text { regimens for eclampsia. } \\
\text { International Journal of } \\
\text { Gynecology and Obstetrics, } \\
\text { 87(2), 149-150. }\end{array}$ & $\begin{array}{l}\text { Experimental } \\
\text { pilot }\end{array}$ & $\begin{array}{l}\text { Usmanu Danfodiyo } \\
\text { University Teaching } \\
\text { Hospital } \\
\text { January 2002- } \\
\text { December 2003 } \\
33 \text { women }\end{array}$ & & $\begin{array}{l}\text { Patients were treated with a modified } \\
\text { regimen that limited } \mathrm{MgSO}_{4} \text { administration } \\
\text { to } 12 \text { hours (vs. 24) and the authors' } \\
\text { primary outcome of interest was recurrent } \\
\text { convulsions. }\end{array}$ & $\begin{array}{l}\text { Pritchard regimen involves use of MgSO } 4 \text { with a habitual } \\
24 \mathrm{~h} \text { administration of maintenance doses after initial } \\
\text { loading dose } \\
\text { This small study tested an alternate regimen that is the } \\
\text { same loading dose as in Pritchard (4g IV and } 5 \mathrm{~g} \text { each } \\
\text { buttock) and maintenance doses every four hours for } 12 \\
\text { hours. } \\
\text { Recurrent convulsion rate was } 6.0 \% \text { (comparable to } 4.7 \% \\
\text { found in the Collaborative Eclampsia Trial } \\
\text { Since cost of magnesium sulfate has been underestimated, } \\
\text { according to the authors, reducing the amount needed to } \\
\text { manage PE/E is better. } \\
\text { Recommend a larger, multicenter randomized (12h vs } 24 \mathrm{~h} \text { ) } \\
\text { trial is needed to validate these findings. }\end{array}$ \\
\hline $\begin{array}{l}\text { Ekele, B. A., \& Badung, S. } \\
\text { L. H. (2005). Is serum } \\
\text { magnesium estimate } \\
\text { necessary in patients with } \\
\text { eclampsia on magnesium } \\
\text { sulphate? African Journal } \\
\text { of Reproductive Health, } \\
9(1), 128-132 .\end{array}$ & Prospective & $\begin{array}{l}\text { Usmanu Danfodiyo } \\
\text { University Teaching } \\
\text { Hospital, Sokoto } \\
\text { January-December } \\
2002 \\
19 \text { patients }\end{array}$ & & $\begin{array}{l}\text { Blood samples were taken from consecutive } \\
\text { patients treated for eclampsia with } \mathrm{MgSO}_{4} \\
\text { prior to administration of the loading dose } \\
\text { and subsequent maintenance doses serum } \\
\text { magnesium levels were estimated } \\
\text { Modified Pritchard regimen was used } \\
\text { (loading dose of } 4 \mathrm{gIV} \text { over } 10 \text { mins followed } \\
\text { by } 10 \mathrm{~g} \text { of deep IM } \mathrm{MgSO}_{4} \text {; followed by } \\
\text { maintenance doses of } 5 \mathrm{~g} \text { every four hours. } \\
\text { Patients were monitored for } \mathrm{MgSO}_{4} \text { toxicity } \\
\text { and calcium gluconate was available, } \\
\text { Blood samples were taken before each } \\
\text { maintenance dose }\end{array}$ & $\begin{array}{l}\text { - } 19 \text { patients completed the study } \\
\text { One patient had recurrent convulsion within } 30 \text { mins of } \\
\text { initiative treatment and was given an additional } 2 \mathrm{~g} I \mathrm{IV} \text { to stop } \\
\text { the seizure. } \\
\text { - None of the patients experienced loss of deep tendon reflex } \\
\text { or respiratory depression; no signs of } \mathrm{MgSO} 4 \text { toxicity } \\
\text { Mean serum magnesium level at baseline was } 1.96 \mathrm{mmol} / \mathrm{L} \text {; } \\
\text { subsequent serum levels }(2.1 \mathrm{mmol} / \mathrm{L}) \text { remained within } \\
\text { suggested therapeutic level of } 2.0-3.5 \mathrm{mmol} / \mathrm{L} \text {. } \\
\text { Based on this small study, the authors conclude that serum } \\
\text { magnesium levels in eclamptic patients receiving only } \\
\text { MgSO4 to manage their seizures remained within } \\
\text { therapeutic range; recommend more widespread use of } \\
\text { magnesium sulphate without the need to estimate serum } \\
\text { magnesium. }\end{array}$ \\
\hline $\begin{array}{l}\text { Ezugwu, E. C., Agu, P. U., } \\
\text { Nwoke, M. O., \& Ezugwu, F. } \\
\text { O. (2014). Reducing } \\
\text { maternal deaths in a low } \\
\text { resource setting in Nigeria. } \\
\text { Nigerian Journal of Clinical } \\
\text { Practice, 17(1), 62-66. }\end{array}$ & $\begin{array}{l}\text { Retrospective } \\
\text { pre/post } \\
\text { intervention } \\
\text { study }\end{array}$ & $\begin{array}{l}\text { Enugu State } \\
\text { University Teaching } \\
\text { Hospital, Nigeria } \\
\text { Jan. 2005-Dec. } \\
2007 \text { \& Jan 2008- } \\
\text { Dec. } 2009 \\
59 \text { maternal deaths }\end{array}$ & & $\begin{array}{l}\text { Reviewed files of all maternal deaths over a } \\
\text { six year period (three years before the } \\
\text { adoption of guidelines aimed at maternal } \\
\text { mortality reduction and three years after) }\end{array}$ & $\begin{array}{l}\text { - } 91 \% \text { retrieval rate, MMR of } 645 \text { per } 100,000 \text { live births. } \\
\text { - } \quad \text { avidence based guidelines were identified through PubMed } \\
\text { and Google scholar and were adapted to the local context. } \\
\text { For this study, resident doctors and nurses were then } \\
\text { trained on the guidelines, which included using the Pritchard } \\
\text { regimen for the management of severe PE/E. } \\
\text { - } \quad \text { After adoption of the guidelines, there was a } 43.5 \% \\
\text { reduction in MMR (488 vs } 864 \text { per } 100,000 \text { live births) } \\
\text { CFR for eclampsia fell by } 80 \% \text { (15.8\% to } 2.7 \%)\end{array}$ \\
\hline
\end{tabular}




\begin{tabular}{|c|c|c|c|c|c|}
\hline Citation & Study Design & $\begin{array}{l}\text { Location, } \\
\text { Timeframe, and } \\
\text { Sample size }\end{array}$ & $\begin{array}{l}\text { Prevalence } \\
/ \\
\text { Incidence/ } \\
\text { CFR }\end{array}$ & Brief summary of methods/intervention & $\begin{array}{l}\text { Main findings/ limitations } \\
\text { Conclusions/ } \\
\text { Recommendations }\end{array}$ \\
\hline $\begin{array}{l}\text { lgwegbe. AO, Eleja, GU, } \\
\text { Ugboaia, JO, \& Ofiaeli, RO. } \\
\text { (2012). Improving maternal } \\
\text { mortality at a university } \\
\text { teaching hospital Nnewi, } \\
\text { Nigeria. International } \\
\text { Journal of Gynecology \& } \\
\text { Obstetrics, 116(3), 197- } \\
200 \text {. }\end{array}$ & $\begin{array}{l}\text { Retrospective } \\
\text { evaluation } \\
\text { study }\end{array}$ & $\begin{array}{l}\text { Nnamdi Azikiwe } \\
\text { University Teaching } \\
\text { Hospital (NAUTH), } \\
\text { Nnewi } \\
\text { January 1, 2004- } \\
\text { December 31, 2010 } \\
\text { 4,916 live births }\end{array}$ & & $\begin{array}{l}\text { This study compared maternal mortality at } \\
\text { the facility during the pre-SERVICOM and } \\
\text { post-SERVICOM periods. }\end{array}$ & $\begin{array}{l}\text { - } \quad \text { As a result of Federal proclamation of a social contract with } \\
\text { all Nigerians to provide "basic services to which each citizen } \\
\text { is entitled in a timely, fair, honest, effective and transparent } \\
\text { manner," all government establishments were required to } \\
\text { prepare a "Service Compact" (SERVICOM) contract with all } \\
\text { Nigerians. } \\
\text { - NAUTH launched a SERVICOM charter in May } 2005 \text { to } \\
\text { improve service delivery to patients including: elimination of } \\
\text { fee-for-service for all emergency services (including obstetric } \\
\text { services); prompt and appropriate treatment, monitoring of } \\
\text { services and record keeping and penalties for "errant staff" } \\
\text { Overall MMR 1098 per 100,000 livebirths over the six year } \\
\text { period. In } 2004, \text { MMR was 1,567 per 100,000 and in } \\
\text { 2010, the MMR } 691 \text { per } 100,000 \text {. } \\
\text { PE/E was most common direct cause of maternal death } \\
\text { (25\%) } \\
\text { Introduction of SERVICOM reduced the delay at the facility to } \\
\text { receive treatment (change in intake and waiver procedures } \\
\text { led to reduction in presentation-intervention interval) }\end{array}$ \\
\hline $\begin{array}{l}\text { Ishaku, S., Ahonsi, B., } \\
\text { Tukur, J., \& Ayodeji, O. } \\
\text { (2013). Attrition from care } \\
\text { after the critical phase of } \\
\text { severe pre-eclampsia and } \\
\text { eclampsia : Insights from } \\
\text { an intervention with } \\
\text { magnesium sulphate in a } \\
\text { primary care setting in } \\
\text { northern Nigeria. Health, } \\
5(9), 1461-1466 .\end{array}$ & Case-control & $\begin{array}{l}\text { PHC facilities in } \\
\text { Kano State, Nigeria } \\
\text { September 2010- } \\
\text { August } 2011 \\
10 \text { PHCs, } 150 \\
\text { patients recruited }\end{array}$ & & $\begin{array}{l}10 \text { PHCs were included, } 5 \text { were in an } \\
\text { experimental arm and } 5 \text { were controls; all } \\
\text { facilities received severe PE/E patients and } \\
\text { performed stabilizing treatment (anti- } \\
\text { hypertensives) before sending patient to } \\
\text { referral centers. } \\
\text { The health workers at the experimental } \\
\text { PHCs were trained to recognize patients with } \\
\text { severe PE/E and were trained to administer } \\
\text { loading dose of MgSO4 (10g IM) before } \\
\text { referral. They also received training on } \\
\text { detecting MgSO4 toxicity and how to } \\
\text { administer the antidote, calcium gluconate. } \\
\text { Health workers at control PHCs did not give } \\
\text { MgSO4 and either gave diazepam or no } \\
\text { anticonvulsant. }\end{array}$ & $\begin{array}{l}\text { - } 75 \% \text { of the women referred to hospitals defaulted; default } \\
\text { rate was higher among those who had been at experimental } \\
\text { PHCs and received the loading dose of MgSO4 } \\
\text { It is possible that the immediate, yet temporary, effect of } \\
\text { MgSO4 gave the false idea that the patients were cured and } \\
\text { that follow up was unnecessary; contributing somewhat to } \\
\text { the higher attrition among the experimental group; the } \\
\text { community needs to be educated about the continuing } \\
\text { dangers of severe PE/E } \\
\text { "With appropriate training and supervision, lower-cadre } \\
\text { health care professionals can safely administer MgSO4 to } \\
\text { treat severe pre-eclampsia and eclampsia without significant } \\
\text { toxic effects in primary care settings in developing } \\
\text { countries." }\end{array}$ \\
\hline $\begin{array}{l}\text { Nkwocha, G. C., Anya, S. E., } \\
\text { \& Anya, A. E. (2006). } \\
\text { Obstetric mortality in a }\end{array}$ & $\begin{array}{l}\text { Retrospective } \\
\text { review of } \\
\text { births and }\end{array}$ & $\begin{array}{l}\text { Federal Medical } \\
\text { Centre, Umuahia, } \\
\text { Abia State. }\end{array}$ & & $\begin{array}{l}\text { This study used hospital records to compare } \\
\text { mortality rates from the period before the } \\
1990 \text { launch of the "Safe Motherhood }\end{array}$ & $\begin{array}{l}\text { - Overall, puerperal sepsis, hypertensive disorders of } \\
\text { pregnancy (pre-eclampsia and eclampsia), hemorrhage and } \\
\text { uterine rupture, together, accounted for } 88 \% \text { of maternal } \\
\text { deaths. }\end{array}$ \\
\hline
\end{tabular}




\begin{tabular}{|c|c|c|c|c|c|}
\hline Citation & Study Design & $\begin{array}{l}\text { Location, } \\
\text { Timeframe, and } \\
\text { Sample size }\end{array}$ & $\begin{array}{l}\text { Prevalence } \\
/ \\
\text { Incidence/ } \\
\text { CFR }\end{array}$ & Brief summary of methods/intervention & $\begin{array}{l}\text { Main findings/ limitations } \\
\text { Conclusions/ } \\
\text { Recommendations }\end{array}$ \\
\hline $\begin{array}{l}\text { Nigerian general hospital. } \\
\text { Nigerian Journal of } \\
\text { Medicine : Journal of the } \\
\text { National Association of } \\
\text { Resident Doctors of } \\
\text { Nigeria, 15(1), 75-76. }\end{array}$ & $\begin{array}{l}\text { maternal } \\
\text { deaths } \\
\text { 'before-and- } \\
\text { after' study }\end{array}$ & $\begin{array}{l}\text { January 1, 1981- } \\
\text { December 31, } 1998 \\
\text { 21,244 deliveries }\end{array}$ & & $\begin{array}{l}\text { Programme" in Nigeria which aimed to } \\
\text { reduce maternal mortality by } 50 \% \text { before } \\
2000 .\end{array}$ & $\begin{array}{l}\text { MMR decreased 8\% from } 4942 \text { per 100,000 before } 1990 \\
\text { and } 4545 \text { per 100,000 from 1990-1998 } \\
\text { Deaths due to PE/E increased after the launch of the Safe } \\
\text { Motherhood Programme: In 1981-1989, pre-eclampsia } \\
\text { caused 4.4\% of maternal deaths and eclampsia caused } \\
\text { 13.9\%. From 1990-1998, PE caused 10.5\% and eclampsia } \\
\text { caused 17.9\% }\end{array}$ \\
\hline $\begin{array}{l}\text { Okereke, E., Ahonsi, B., } \\
\text { Tukur, J., Ishaku, S. M., \& } \\
\text { Oginni, A. B. (2012). } \\
\text { Benefits of using } \\
\text { magnesium sulphate } \\
\text { (MgSO(4)) for eclampsia } \\
\text { management and maternal } \\
\text { mortality reduction: } \\
\text { lessons from Kano State in } \\
\text { Northern Nigeria. BMC } \\
\text { Research Notes, 5, 421. }\end{array}$ & $\begin{array}{l}\text { Retrospective } \\
\text { study; before- } \\
\text { and-after }\end{array}$ & $\begin{array}{l}\text { Bayero } \\
\text { University/Aminu } \\
\text { Kano Teaching } \\
\text { Hospital, Kano } \\
\text { Baseline: 2006- } \\
2007 \\
\text { Intervention: } \\
\text { February 2008- } \\
\text { January 2009 } \\
\text { Baseline: } 1,233 \\
\text { patients } \\
\text { Intervention: } 1045 \\
\text { patients (49 severe } \\
\text { PE, } 996 \text { eclampsia) }\end{array}$ & & $\begin{array}{l}\text { Data for the study was obtained from } \\
\text { obstetric records for eclamptic patients. } \\
\text { For baseline: patients were treated using } \\
\text { diazepam, which was commonly available } \\
\text { Intervention: doctors and midwives were } \\
\text { trained to use } \mathrm{MgSO}_{4} \text { following protocol and } \\
\text { detect and treat } \mathrm{MgSO}_{4} \text { toxicity (using } \\
\text { calcium gluconate) }\end{array}$ & $\begin{array}{l}\text { - } 52 \% \text { of the patients were teenagers, } 60.4 \% \text { were } \\
\text { primigravidae, } 74.1 \% \text { were illiterate, } 71 \% \text { were in } \\
\text { monogamous relationships } \\
\text { This study found a reduction in case fatality among } \\
\text { eclampsia patients from } 20.9 \%(95 \% \mathrm{Cl}: 18.7,23.2) \text { at } \\
\text { baseline to } 2.3 \%(1.4,3.2) \text { during intervention period. } \\
\text { - } 92.5 \% \text { of patients treated with MgSO } 4 \text { did not have } \\
\text { recurrent convulsions } \\
\text { This study found that training providers on protocol for } \\
\text { treating severe PE/E with MgSO4 is effective to reduce CFR } \\
\text { due to eclampsia and there is no significant difference in } \\
\text { cost of MgSO4 vs. diazepam. }\end{array}$ \\
\hline $\begin{array}{l}\text { Okonofua, FE et al. } \\
\text { “Training Health Workers } \\
\text { for Magnesium Sulfate Use } \\
\text { Reduces Case Fatality from } \\
\text { Eclampsia: Results from a } \\
\text { Multicenter Trial." Acta } \\
\text { obstetricia et gynecologica } \\
\text { Scandinavica } 92 \text { (2013): } \\
716-720 .\end{array}$ & $\begin{array}{l}\text { Multicenter } \\
\text { trial } \\
\text { 'before-and- } \\
\text { after' }\end{array}$ & $\begin{array}{l}\text { Kano, Lagos, } \\
\text { Calabar, Jos, } \\
\text { Maiduguri, Enugu } \\
\text { Baseline: January- } \\
\text { May } 2008 \\
\text { Training: April-June } \\
2009\end{array}$ & $\begin{array}{l}\text { Incidence } \\
\text { of } \\
\text { eclampsia } \\
\text { baseline: } \\
1.5 \% \\
\text { interventio } \\
\text { n: } 1.4 \%\end{array}$ & $\begin{array}{l}\text { Baseline: review of hospital records and in- } \\
\text { depth interviews with providers to inform } \\
\text { development of training curriculum. } \\
\text { Training: mandatory 3-day workshop on } \\
\text { epidemiology of maternal mortality, clinical } \\
\text { features of eclampsia, ways to overcome } \\
\text { limitations in the healthcare system in } \\
\text { managing eclampsia, protocols on } \mathrm{MgSO}_{4} \text {. } \\
\text { Intervention: use of Pritchard regimen to } \\
\text { treat } \mathrm{MgSO}_{4} \text { and guidelines on use and } \\
\text { timing of anti-hypertensives and monitoring } \\
\text { patient. }\end{array}$ & $\begin{array}{l}\text { - Aminu Kano Teaching Hospital, Lagos State University } \\
\text { Teaching Hospital, University of Calabar Teaching Hospital, } \\
\text { University of Jos Teaching Hospital, University of Maiduguri } \\
\text { Teaching Hospital, University of Nigeria Teaching Hospital } \\
\text { Multi-professional trainings included: Ob/Gyns, doctors in } \\
\text { training, nurses, midwives, nurses/midwives in training, staff } \\
\text { from related departments and senior management } \\
\text { - The results from pre- and post-tests at the training sessions } \\
\text { indicate a significant increase in knowledge related to } \\
\text { eclampsia management } \\
\text { During one year after the intervention, } 219 \text { eclampsia cases } \\
\text { were treated; compared to baseline, a similar incidence of } \\
\text { eclampsia was seen but maternal mortality was significantly } \\
\text { reduced }\end{array}$ \\
\hline
\end{tabular}




\begin{tabular}{|c|c|c|c|c|c|}
\hline Citation & Study Design & $\begin{array}{l}\text { Location, } \\
\text { Timeframe, and } \\
\text { Sample size }\end{array}$ & $\begin{array}{l}\text { Prevalence } \\
/ \\
\text { Incidence/ } \\
\text { CFR }\end{array}$ & Brief summary of methods/intervention & $\begin{array}{l}\text { Main findings/ limitations } \\
\text { Conclusions/ } \\
\text { Recommendations }\end{array}$ \\
\hline & & $\begin{array}{l}\text { Six teaching } \\
\text { hospitals in Nigeria }\end{array}$ & $\begin{array}{l}\text { Baseline: } \\
15.1 \% \\
\text { endline: } \\
3.2 \%\end{array}$ & $\begin{array}{l}\text { Endline: clinical records of cases of } \\
\text { eclampsia for one year after the intervention } \\
\text { were reviewed and analyzed }\end{array}$ & $\begin{array}{l}\text { - Perinatal mortality rate reduced slightly, but the difference } \\
\text { was not significant ( } 141.5 \text { per } 1,000 \text { at baseline, } 129.8 \text { per } \\
1,000 \text { after intervention, } p=0.32 \text { ). } \\
\text { - } 13.5 \% \text { of newborns had low birthweight after the } \\
\text { intervention } \\
\text { "Key message: building the capacity of healthcare providers } \\
\text { to use magnesium sulfate for the treatment of eclampsia is } \\
\text { an effective intervention for reducing the number of deaths } \\
\text { due to eclampsia in low-income countries" }\end{array}$ \\
\hline $\begin{array}{l}\text { Okusanya, B O, K D Garba, } \\
\text { and H M Ibrahim. "The } \\
\text { Efficacy of Intramuscular } \\
\text { Loading Dose of MgSO4 in } \\
\text { Severe Pre-Eclampsia/ } \\
\text { Eclampsia at a Tertiary } \\
\text { Referral Centre in } \\
\text { Northwest Nigeria." The } \\
\text { Nigerian postgraduate } \\
\text { medical journal 19.2 } \\
\text { (2012): } 77-82 .\end{array}$ & $\begin{array}{l}\text { Descriptive } \\
\text { comparative } \\
\text { study }\end{array}$ & $\begin{array}{l}\text { Federal Medical } \\
\text { Centre Katsina } \\
\text { 10g dose: } \\
\text { April 1, 2008-April } \\
30,2009 \\
\text { 14g dose: } \\
\text { May 1, 2009- } \\
\text { October } 25,2009 \\
10 g \text { dose } 54 \text { women } \\
\text { 14g dose: } 49 \\
\text { women }\end{array}$ & & $\begin{array}{l}\text { All women presenting with severe } \mathrm{PE} / \mathrm{E} \text { were } \\
\text { prospectively enrolled during two periods; } \\
\text { the first receiving a } 10 \mathrm{~g} \text { loading dose of } \\
\mathrm{MgSO}_{4} \text { and the second period using a } 14 \mathrm{~g} \\
\text { loading dose. } \\
\text { Severe PE: BP } 116 / 110 \mathrm{mmHg} \text { and } \\
\text { proteinuria of at least } 2+ \\
\text { Eclampsia: occurrence of convulsions in } \\
\text { women with severe PE }\end{array}$ & $\begin{array}{l}\text { - } 55 \text { women had severe PE ( } 25 \text { were in } 10 \mathrm{~g} \text { group. } 30 \text { in } 14 \mathrm{~g} \\
\text { group) } \\
48 \text { had eclampsia ( } 29 \text { in } 10 \mathrm{~g} \text { group and } 19 \text { in } 14 \mathrm{~g} \text { group) } \\
\text { - Two ( } 7 \% \text { ) of the women in the } 10 \mathrm{~g} \text { group had recurrent } \\
\text { convulsions and none who were in the } 14 \mathrm{~g} \text { group } \\
\text { experienced recurrent convulsions (difference is not } \\
\text { significant). } \\
\text { Rates of vaginal delivery, onset of convulsion/recurrent } \\
\text { convulsion, maternal death and neonatal Apgar score did } \\
\text { not have statistically significant rates between the two } \\
\text { groups. } \\
10 \mathrm{~g} \text { IM loading dose prevented eclampsia in } 80 \% \text { of women } \\
\text { with severe PE and prevented recurrent convulsions in } 93 \% \\
\text { of women with eclampsia. } \\
\text { Using } 10 g \text { did not increase chances of caesarean section or } \\
\text { severe birth asphyxia at } 5 \text { minutes. } \\
\text { The six perinatal deaths observed were all in women in the } \\
10 g \text { groups, but these women were admitted with } \\
\text { intrauterine fetal demise before treatment was delivered. } \\
\text { RCT is needed to confirm efficacy and safety of lower loading } \\
\text { dose for potential use at lower level facilities. }\end{array}$ \\
\hline $\begin{array}{l}\text { Onah, H., \& Iloabachie, G. } \\
\text { (2002). Conservative } \\
\text { management of early-onset } \\
\text { pre-eclampsia and } \\
\text { fetomaternal outcome in } \\
\text { Nigerians. Journal of } \\
\text { Obstetrics and } \\
\text { Gynaecology, 22(4), 357- } \\
362 \text {. }\end{array}$ & $\begin{array}{l}\text { Prospective } \\
\text { case control }\end{array}$ & $\begin{array}{l}\text { University of Nigeria } \\
\text { Teaching Hospital, } \\
\text { Enugu } \\
\text { May } 5,2005-J u n e \\
30,2000 \\
175 \text { study group } \\
574 \text { controls }\end{array}$ & $\begin{array}{l}\text { CFR } \\
\text { among } \\
\text { early } \\
\text { onset: } \\
33.3 \% \\
\text { CFR } \\
\text { among late } \\
\text { onset: } \\
7.1 \%\end{array}$ & $\begin{array}{l}749 \text { consecutive cases of PE were recruited. } \\
\text { The early-onset cases (PE manifested before } \\
30 \text { weeks gestation) formed the study group } \\
\text { and the remaining cases were the controls. } \\
\text { Demographic and obstetric details were } \\
\text { recorded including gestational age at onset } \\
\text { of disease as well as BP and urine test. } \\
\text { After being admitted, patients were routinely } \\
\text { tested for :full blood count, serum } \\
\text { electrolytes, urea and creatinine, liver } \\
\text { function tests, clotting profile, urinalysis and } \\
\text { ultrasonography, they were put on bed rest, }\end{array}$ & $\begin{array}{l}\text { - } \quad \text { 'Pure' PE: hypertension associated with proteinuria in } \\
\text { previously normotensive women. } \\
\text { - Superimposed PE: significant aggravation of preexisting } \\
\text { hypertension associated with sustained proteinuria } \\
\text { - Alpha-methyldopa and hydrallazine were used to control high } \\
\text { BP above } 160 / 110 \mathrm{mmHg} \text { (methyldopa was used } \\
\text { antepartum and hydrallazine used to manage hypertensive } \\
\text { crises, eclampsia and during peripartum). } \\
\text { - Seizures were controlled using diazepam (MgSO4 was } \\
\text { unavailable). } \\
\text { Early onset group experienced } 14 \text { maternal deaths (7 due to } \\
\text { eclampsia, 3: renal failure, 2: HELLP syndrome, 1: } \\
\text { anesthetic accident, 1: septicemia from AIDS) -80\% of early } \\
\text { onset group gained two weeks gestation. }\end{array}$ \\
\hline
\end{tabular}




\begin{tabular}{|c|c|c|c|c|c|}
\hline Citation & Study Design & $\begin{array}{l}\text { Location, } \\
\text { Timeframe, and } \\
\text { Sample size }\end{array}$ & $\begin{array}{l}\text { Prevalence } \\
\text { / } \\
\text { Incidence/ } \\
\text { CFR }\end{array}$ & Brief summary of methods/intervention & $\begin{array}{l}\text { Main findings/ limitations } \\
\text { Conclusions/ } \\
\text { Recommendations }\end{array}$ \\
\hline & & & & $\begin{array}{l}\text { given diazepam and anti-hypertensives as } \\
\text { deemed necessary by the physician. }\end{array}$ & $\begin{array}{l}\text { Causes of death in the late onset group were: eclampsia=7, } \\
\text { renal failure=6, abruptio placentae }=5 \text {, anesthesia-related } \\
\text { causes }=4, \text { cerebrovascular accident }=2, \text { HELLP syndrome=2, } \\
\text { associated diabetic ketoacidocis=1, septicaemia from } \\
\text { AIDS=1 } \\
\text { Based on the high CFR among early onset cases, the } \\
\text { authors recommend that these cases be managed } \\
\text { conservatively to improve fetal and maternal outcomes }\end{array}$ \\
\hline $\begin{array}{l}\text { Tukur, J., Ahonsi, B., } \\
\text { Ishaku, S. M., Araoyinbo, I., } \\
\text { Okereke, E., \& Babatunde, } \\
\text { A. O. (2013). Maternal and } \\
\text { fetal outcomes after } \\
\text { introduction of magnesium } \\
\text { sulphate for treatment of } \\
\text { preeclampsia and } \\
\text { eclampsia in selected } \\
\text { secondary facilities: a low- } \\
\text { cost intervention. Maternal } \\
\text { and Child Health Journal, } \\
\text { 17(7), 1191-1198. }\end{array}$ & $\begin{array}{l}\text { Before and } \\
\text { after }\end{array}$ & $\begin{array}{l}\text { Kano, Bichi, Wudil, } \\
\text { Gwarzo, Rano, } \\
\text { Minjibir, Tudun } \\
\text { Wada, Doguwa, } \\
\text { Rano, Rogo } \\
\text { February 1, 2008- } \\
\text { January 31, } 2009\end{array}$ & $\begin{array}{l}\text { baseline } \\
\text { CFR: } \\
20.9 \% \\
\text { post } \\
\text { interventio } \\
\text { n CFR: } \\
2.3 \%\end{array}$ & $\begin{array}{l}\text { Five hospital officials from the Hospitals } \\
\text { Management Board and one doctor and one } \\
\text { midwife from each of the ten facilities were } \\
\text { invited to participate in a training. The two- } \\
\text { day training provided didactic lectures on } \\
\text { evidence-based management of } \\
\text { hypertensive disorders of pregnancy and use } \\
\text { of } \mathrm{MgSO}_{4} \text {. Participants were taught to } \\
\text { administer } 4 \mathrm{~g} \mathrm{MgSO}_{4} \mathrm{IV} \text { and } 10 \mathrm{~g} \mathrm{IM} \text { followed } \\
\text { by } 5 \mathrm{~g} \mathrm{IM} \text { every } 6 \text { hours until } 24 \text { hours after } \\
\text { delivery or the last seizure and also to } \\
\text { monitor for toxicity by checking deep tendon } \\
\text { knee reflex. } \\
\text { Data was then collected on maternal } \\
\text { sociodemographics, pattern of severe PE/E, } \\
\text { and fetomaternal outcomes at the ten } \\
\text { facilities and compared to baseline survey } \\
\text { from three general hospitals }\end{array}$ & $\begin{array}{l}\text { - Baseline surveys showed that } 1,233 \text { patients with severe } \\
\text { PE/E, } 258 \text { died : baseline CFR: } 20.9 \% \\
25 \text { master trainers participated in the training and } \\
\text { subsequently trained } 160 \text { health workers (doctors, } \\
\text { midwives, and community health extension workers) } \\
\text { During the project period, } 49 \text { cases of severe PE and } 996 \\
\text { cases of eclampsia were treated at the facilities out of a } \\
\text { total of } 22,502 \text { deliveries } \\
322 \text { cases of eclampsia manifested antepartum, } 430 \text { were } \\
\text { intrapartum, and } 244 \text { developed postpartum } \\
\text { - } \text { After the intervention, only } 24 \text { of the } 1045 \text { cases died, } \\
\text { significantly reducing the CFR associated with severe PE/E. } \\
\text { Perinatal mortality was } 12.3 \% \text { (129 of } 1045 \text { ); perinatal } \\
\text { mortality was significantly higher among patients who } \\
\text { experienced three or more convulsions (there was no } \\
\text { baseline perinatal mortality rate, but another facility that } \\
\text { uses diazepam reported a } 35.3 \% \text { stillbirth rate). } \\
\text { Introducing MgSO for severe PE/E is a low-cost and } \\
\text { replicable intervention that has a positive effect on maternal } \\
\text { and fetal morbidity and mortality and should be scaled up. }\end{array}$ \\
\hline $\begin{array}{l}\text { Tukur, J., Ogedengbe, C., } \\
\text { Nwanchukwu, E., } \\
\text { Araoyinbo, I. A., Yakasai, I. } \\
\text { A., Adaji, S. E., \& Ajala, B. } \\
\text { (2011). Introduction of an } \\
\text { innovation for the } \\
\text { reduction of maternal } \\
\text { mortality in Kano State, } \\
\text { northern Nigeria: a case } \\
\text { study of magnesium }\end{array}$ & & $\begin{array}{l}\text { Kano State } \\
\text { Feb-December } \\
2008 \\
1045 \text { patients } \\
\text { treated with } \mathrm{MgSO}_{4}\end{array}$ & CFR: $2.3 \%$ & $\begin{array}{l}\mathrm{MgSO}_{4} \text { was introduced to ten general } \\
\text { hospitals and data was collected from the } \\
\text { facilities to monitor the intervention. A } \\
\text { workshop on } \mathrm{MgSO}_{4} \text { use and monitoring was } \\
\text { conducted and } 25 \text { master trainers took the } \\
\text { knowledge they acquired and conducted } \\
\text { step down trainings to } 160 \text { clinical } \\
\text { providers. }\end{array}$ & $\begin{array}{l}\text { - } 60.4 \% \text { of the patients treated with MgSO4 were primigravida } \\
\text { and } 44.1 \% \text { had no form of ANC } \\
23 \text { women (2.2\%) experienced toxic effects associated with } \\
\text { MgSO4 but they were treated with calcium gluconate and no } \\
\text { morbidity or mortality resulted } \\
\text { - } 24 \text { mothers died, and } 129 \text { (12.3\%) of the babied were } \\
\text { delivered dead } \\
\text { - The } 24 \text { deaths in this study made up } 4.9 \% \text { of all maternal } \\
\text { deaths during the } 12 \text { month period of the project }\end{array}$ \\
\hline
\end{tabular}




\begin{tabular}{|c|c|c|c|c|c|}
\hline Citation & Study Design & $\begin{array}{l}\text { Location, } \\
\text { Timeframe, and } \\
\text { Sample size }\end{array}$ & $\begin{array}{l}\text { Prevalence } \\
/ \\
\text { Incidence/ } \\
\text { CFR }\end{array}$ & Brief summary of methods/intervention & $\begin{array}{l}\text { Main findings/ limitations } \\
\text { Conclusions/ } \\
\text { Recommendations }\end{array}$ \\
\hline $\begin{array}{l}\text { sulphate. Tropical Doctor, } \\
41(4), 197-200 .\end{array}$ & & & & $\begin{array}{l}\text { Prior to these trainings, a pilot survey was } \\
\text { conducted to assess the use of } \mathrm{MgSO}_{4} \text { in } \\
\text { general hospitals. Advocacy visits were then } \\
\text { necessary to explain to health officials the } \\
\text { evidence for the effectiveness of } \mathrm{MgSO}_{4} \text {. }\end{array}$ & $\begin{array}{l}\text { - Compared to maternal deaths due to eclampsia during the } \\
12 \text { months prior to the intervention (268/567; } 47.3 \%) \text {, the } \\
\text { attributable deaths from eclampsia reduced by } 42.4 \% \\
\text { This project was successful because it was evidence-based, } \\
\text { sustainable through stakeholder involvement, and } \\
\text { replicable. }\end{array}$ \\
\hline $\begin{array}{l}\text { Tukur, J., Umar, N. I., Khan, } \\
\text { N., \& Musa, D. (2007). } \\
\text { Comparison of emergency } \\
\text { caesarean section to } \\
\text { misoprostol induction for } \\
\text { the delivery of antepartum } \\
\text { eclamptic patients: a pilot } \\
\text { study. Nigerian Journal of } \\
\text { Medicine: Journal of the } \\
\text { National Association of } \\
\text { Resident Doctors of } \\
\text { Nigeria, } 16(4), 364-367 .\end{array}$ & $\begin{array}{l}\text { Randomized } \\
\text { pilot study }\end{array}$ & $\begin{array}{l}\text { Federal Medical } \\
\text { Centre Azare, } \\
\text { Bauchi } \\
50 \text { eclamptic } \\
\text { patients }\end{array}$ & & $\begin{array}{l}\text { Primigravida patients with singleton } \\
\text { pregnancies presenting with antepartum or } \\
\text { imminent eclampsia and a closed cervical os } \\
\text { were randomized for delivery by CS or by } \\
\text { induced labor using misoprostol. }\end{array}$ & $\begin{array}{l}\text { - Misoprostol failure rate was } 4 \text { patients (16\%); these four } \\
\text { were subsequently delivered by CS. } \\
\text { The CS group spent an average } 10.1 \text { days in the center } \\
\text { compared to } 6.08 \text { days spent on average in the center by } \\
\text { the misoprostol group. } \\
\text { Maternal complications and admissions of babies were } \\
\text { frequent in the CS group. } \\
\text { - Maternal mortality in each group was } 4 \% \\
\text { Given the findings of this pilot study, the authors } \\
\text { recommend using misoprostol (cheap, available, and safe } \\
\text { for delivery of antepartum eclamptics) in the event of a delay } \\
\text { for CS. A larger, multi-center study is also suggested. }\end{array}$ \\
\hline $\begin{array}{l}\text { Ugwu, E. O. V, Dim, C. C., } \\
\text { Okonkwo, C. D., \& } \\
\text { Nwankwo, T. O. (2011). } \\
\text { Maternal and perinatal } \\
\text { outcome of severe pre- } \\
\text { eclampsia in Enugu, } \\
\text { Nigeria after introduction } \\
\text { of Magnesium sulfate. } \\
\text { Nigerian Journal of Clinical } \\
\text { Practice, 14(4), 418-421. }\end{array}$ & $\begin{array}{l}\text { Retrospective } \\
\text { case review } \\
\text { Before-and- } \\
\text { after }\end{array}$ & $\begin{array}{l}\text { University of Nigeria } \\
\text { Teaching Hospital } \\
\text { Enugu } \\
\text { January } 12005- \\
\text { December } 31,2008 \\
\text { Diazepam: } 47 \\
\text { women } \\
\text { MgSO}_{4}: 30 \text { women }\end{array}$ & $\begin{array}{l}\text { Prevalence } \\
\text { of severe } \\
\text { PE: } 3.3 \% \\
\text { CFR } \\
\text { before: } \\
\text { CFR after: }\end{array}$ & $\begin{array}{l}\text { This retrospective case review looked at } \\
\text { cases of severe PE and the maternal and } \\
\text { perinatal outcomes for two years before and } \\
\text { two years after the introduction of } \mathrm{MgSO}_{4} \text { as } \\
\text { standard treatment for severe PE in } 2007 \\
\text { (previously diazepam). }\end{array}$ & $\begin{array}{l}\text { - } 77 \text { cases of severe PE over the four year period; } 49.4 \% \text { were } \\
\text { primigravidae } \\
\text { One woman from the diazepam group experienced tonic- } \\
\text { clonic seizures, none of the women in the MgSO4 group } \\
\text { experienced seizures after the initiation of the treatment; no } \\
\text { maternal death occurred in either group. } \\
\text { Women in the diazepam group were more likely to } \\
\text { experience prolonged hospital stay compared to the MgSO4 } \\
\text { group. } \\
25 \text { of the } 79 \text { babies died within the perinatal period ( } 2 \text { sets } \\
\text { of twins) giving a perinatal case fatality rate of } 32.5 \%-\text {-but } \\
\text { there was not a significant difference in perinatal mortality } \\
\text { between the groups. } \\
\text { This study showed that MgSO4 is the most effective and } \\
\text { safest drug to manage convulsions in severe PE and results } \\
\text { in reduced maternal and perinatal morbidity when compared } \\
\text { to diazepam. }\end{array}$ \\
\hline
\end{tabular}




\section{Appendix IV:}

\section{SUMMIARY TABLES OF DEMONSTRATED AND POTENTIAL RISK FACTORS FOR PE/E}

\begin{tabular}{|c|c|c|c|c|c|}
\hline Citation & Study Design & $\begin{array}{l}\text { Location, } \\
\text { Timeframe, and } \\
\text { Sample size }\end{array}$ & $\begin{array}{l}\text { Prevalence } \\
\text { / } \\
\text { Incidence/ } \\
\text { CFR }\end{array}$ & Brief summary of Methods & $\begin{array}{l}\text { Main findings/ limitations } \\
\text { Conclusions/ } \\
\text { Recommendations }\end{array}$ \\
\hline $\begin{array}{l}\text { Abubakar, A., Abdullahi, R., HZ, J., } \\
\text { Dauda, M. H., \& MA, P. (2009). } \\
\text { Maternal Ethnicity and Severity of } \\
\text { Pre-Eclampsia in Northern Nigeria. } \\
\text { Asian Journal of Medical Sciences, } \\
\text { 1(3), 104-107. }\end{array}$ & & $\begin{array}{l}\text { Primary Health } \\
\text { Centers in Katsina, } \\
\text { Adamawa and Borno } \\
\text { States } \\
\text { February-August } \\
2009 \\
61 \text { cases of severe } \\
\text { PE }\end{array}$ & N/A & $\begin{array}{l}\text { Blood pressure measured and } \\
\text { monitored. BMl calculated. Total serum } \\
\text { cholesterol, triglyceride, high and low } \\
\text { density lipoproteins were determined } \\
\text { from a blood sample taken after } \\
\text { overnight fasting. Urinalysis began. } \\
-22 \text { in Group A (Hausa) } \\
-20 \text { in Group B (Kanuri) } \\
-19 \text { in Group C (Fulani) }\end{array}$ & $\begin{array}{l}\text { - No significant difference in the severity of } \\
\text { pre-eclampsia between the Hausa and } \\
\text { Kanuri, though they demonstrated } \\
\text { elevated levels of triglyceride, serum } \\
\text { cholesterol, pathological edema, increase } \\
\text { in blood pressure, and higher levels of } \\
\text { urine protein. } \\
\text { The Fulani group showed higher levels of } \\
\text { the above and were more likely to } \\
\text { progress to eclampsia than the other two } \\
\text { tribes. }\end{array}$ \\
\hline $\begin{array}{l}\text { Ademuyiwa, O., Odusoga, O. L., } \\
\text { Adebawo, O. O., \& Ugbaja, R. (2007). } \\
\text { Endogenous antioxidant defences in } \\
\text { plasma and erythrocytes of pregnant } \\
\text { women during different trimesters of } \\
\text { pregnancy. Acta Obstetricia et } \\
\text { Gynecologica Scandinavica, 86(10), } \\
1175-1182 .\end{array}$ & Case-Control & $\begin{array}{l}\text { Obstetrics } \\
\text { Departments of } \\
\text { Sacred Heart } \\
\text { Hospital Abeokuta, } \\
\text { Nigeria and Olabisi } \\
\text { Onabanjo University } \\
\text { Teaching Hospital, } \\
\text { Sagamu Nigeria } \\
97 \text { pregnant } \\
\text { women, } 7 \text { with new } \\
\text { onset of PE } \\
\text { Controls (n=20) } \\
\text { female students } \\
\text { from University of } \\
\text { Agriculture, } \\
\text { Abeokuta, Nigeria } \\
\text { and Olabisi }\end{array}$ & & $\begin{array}{l}\text { Blood samples taken from all } \\
\text { participants for exzymatic } \\
\text { determinations. The study looked at: } \\
\text { enzymic antioxidants (SOD, CAT, GST), } \\
\text { non-enzymic antioxidant (GSH), and a } \\
\text { heme biosynthetic enzyme, } \\
\text { aminolevulinic acid dehydratase (ALAD) } \\
\text { to determine characterize the profiles of } \\
\text { antioxidant response in pregnant } \\
\text { women. }\end{array}$ & $\begin{array}{l}\text { - This study showed an increased plasma } \\
\text { activity of Mn-SOD and statistically } \\
\text { significant low values of erythrocyte CAT, } \\
\text { SOD and ALAD activities in PE compared } \\
\text { to healthy pregnant women } \\
\text { Other antioxidants in plasma and } \\
\text { erythrocytes remain unchanged } \\
\text { The data from this study supports } \\
\text { hypothesis that 'oxidative stress' (OS) } \\
\text { occurring secondary to impaired oxidant } \\
\text { defenses, might be one mechanism } \\
\text { underlying the pathophysiology of pre- } \\
\text { eclampsia (small sample size, needs } \\
\text { further studies) }\end{array}$ \\
\hline
\end{tabular}




\begin{tabular}{|c|c|c|c|c|c|}
\hline Citation & Study Design & $\begin{array}{l}\text { Location, } \\
\text { Timeframe, and } \\
\text { Sample size }\end{array}$ & $\begin{array}{l}\text { Prevalence } \\
/ \\
\text { Incidence/ } \\
\text { CFR }\end{array}$ & Brief summary of Methods & $\begin{array}{l}\text { Main findings/ limitations } \\
\text { Conclusions/ } \\
\text { Recommendations }\end{array}$ \\
\hline & & $\begin{array}{l}\text { Onabanjo University, } \\
\text { Ikenne, Nigeria. }\end{array}$ & & & \\
\hline $\begin{array}{l}\text { Adeyinka, D., Oladimeji, O., } \\
\text { Adekanbi, T., Adeyinka, F., Falope, Y., } \\
\text { \& Aimakhu, C. (2010). Outcome of } \\
\text { adolescent pregnancies in } \\
\text { southwestern Nigeria: A case control } \\
\text { study. Journal of Maternal-Fetal and } \\
\text { Neonatal Medicine, 23(8), 785- } \\
789 .\end{array}$ & $\begin{array}{l}\text { Retrospective } \\
\text { case control }\end{array}$ & $\begin{array}{l}\text { University College } \\
\text { Hospital, Ibadan, } \\
\text { Nigeria } \\
\text { January } 2007- \\
\text { November } 2008 \\
45 \text { cases, } \\
90 \text { controls }\end{array}$ & $\begin{array}{l}\text { Incidence } \\
\text { of PE/E } \\
\text { among } \\
\text { cases: } 20 \% \\
\text { Incidence } \\
\text { of PE/E } \\
\text { among } \\
\text { controls: } \\
3.33 \%\end{array}$ & $\begin{array}{l}\text { Cases were women aged }<18 \text { years and } \\
\text { controls were between } 20 \text { and } 35 \text { years }\end{array}$ & $\begin{array}{l}\text { Defined pre-eclampsia as hypertension ( }> \\
140 / 90 \mathrm{mmHg} \text { on two occasions } 4 \text { hours } \\
\text { apart) and proteinuria }(>0.3 \mathrm{dg} / \mathrm{dl}) \text { in the } \\
\text { second half of pregnancy. Eclampsia = } \\
\text { associated with convulsions, oliguria } \\
\text { ( }>400 \mathrm{ml} / 24 \mathrm{~h}) \text {, increased tendon reflex, } \\
\text { pain in the right hypochondriac region. } \\
\text { Adolescents were significantly more likely } \\
\text { to develop PE/E than their non-adolescent } \\
\text { counterparts. }\end{array}$ \\
\hline $\begin{array}{l}\text { Adokiye, E., Isreal, J., C, H. T., \& Levi, } \\
\text { W. O. (2015). Factors influencing the } \\
\text { prevalence of Preeclampsia- } \\
\text { eclampsia in booked and unbooked } \\
\text { patients: } 3 \text { years retrospective study } \\
\text { in NDUTH, Okolobiri. World Journal } \\
\text { of Medicine and Medical Science, } \\
\text { 3(1), 1-14. }\end{array}$ & $\begin{array}{l}\text { Retrospective } \\
\text { case review }\end{array}$ & $\begin{array}{l}\text { Department of } \\
\text { Obstetrics and } \\
\text { Gynaecology, Niger } \\
\text { Delta University } \\
\text { Teaching Hospital, } \\
\text { Okolobiri, Nigeria } \\
\text { January 1, 2011- } \\
\text { December 31, 2013 } \\
\text { 1,667 deliveries }\end{array}$ & $\begin{array}{l}\text { Incidence } \\
\text { of PE/E: } \\
5.69 \% \\
\text { Eclampsia } \\
\text { only: } \\
2.16 \%\end{array}$ & $\begin{array}{l}\text { Review of medical records for all } \\
\text { pregnant women admitted and } \\
\text { managed to delivery during the study } \\
\text { period. }\end{array}$ & 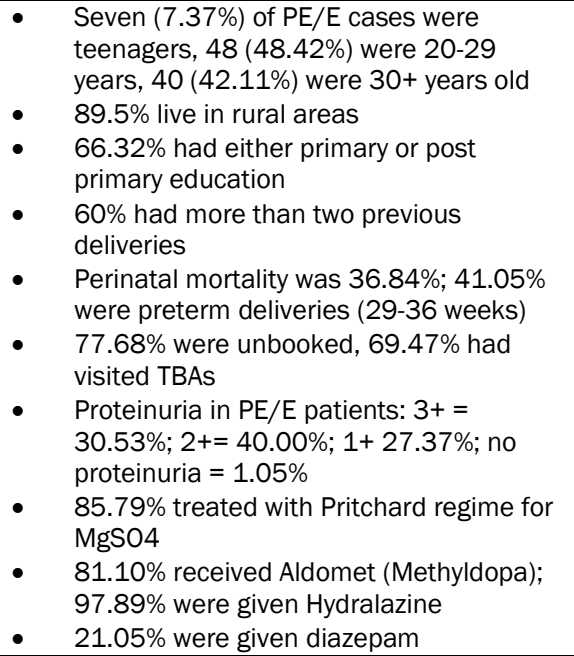 \\
\hline $\begin{array}{l}\text { Afolabi, B. B., Iwuala, N. C., Iwuala, I. } \\
\text { C., \& Ogedengbe, O. K. (2009). } \\
\text { Morbidity and mortality in sickle cell } \\
\text { pregnancies in Lagos, Nigeria: a } \\
\text { case control study. Journal of } \\
\text { Obstetrics and Gynaecology: The } \\
\text { Journal of the Institute of Obstetrics } \\
\text { and Gynaecology, 29(2), 104-106. }\end{array}$ & $\begin{array}{l}\text { Retrospective } \\
\text { case control }\end{array}$ & $\begin{array}{l}\text { Department of } \\
\text { Obstetrics and } \\
\text { Gynaecology, Lagos } \\
\text { University Teaching } \\
\text { Hospital, Idi-Araba, } \\
\text { Lagos, Nigeria }\end{array}$ & & $\begin{array}{l}\text { Examination of delivery records for all } \\
\text { pregnant } \mathrm{HbSS} \text { women delivering during } \\
\text { study period and the case notes of the } \\
\text { next two delivering age-and parity- } \\
\text { matched HbAA women were retrieved. }\end{array}$ & $\begin{array}{l}\text { - Among HbAA women 5.6\% developed PE } \\
\text { and 1.3\% developed eclampsia; among } \\
\text { HbSS women, } 6.7 \% \text { developed PE and } \\
\text { none developed eclampsia } \\
\text { This study did not find that HbSS women } \\
\text { were at a higher risk of developing PE; the } \\
\text { power of this study is not enough to make } \\
\text { conclusions }\end{array}$ \\
\hline
\end{tabular}




\begin{tabular}{|c|c|c|c|c|c|}
\hline Citation & Study Design & $\begin{array}{l}\text { Location, } \\
\text { Timeframe, and } \\
\text { Sample size }\end{array}$ & $\begin{array}{l}\text { Prevalence } \\
/ \\
\text { Incidence/ } \\
\text { CFR }\end{array}$ & Brief summary of Methods & $\begin{array}{l}\text { Main findings/ limitations } \\
\text { Conclusions/ } \\
\text { Recommendations }\end{array}$ \\
\hline & & $\begin{array}{l}\text { January } 1996- \\
\text { December } 2000 \\
75 \text { women with } \\
\text { HbSS and } 150 \\
\text { women with HbAA }\end{array}$ & & & \\
\hline $\begin{array}{l}\text { Airede, L., \& Ekele, B. (2003). } \\
\text { Adolescent maternal mortality in } \\
\text { Sokoto, Nigeria. Journal of Obstetrics } \\
\text { and Gynaecology, 23(2), 163-165. }\end{array}$ & $\begin{array}{l}\text { Retrospective, } \\
\text { cross-sectional } \\
\text { study }\end{array}$ & $\begin{array}{l}\text { Usmanu Danfodiyo } \\
\text { University Teaching } \\
\text { Hospital, Sokoto } \\
\text { January } 1990 \text { to } \\
\text { December } 1999\end{array}$ & & $\begin{array}{l}\text { Information relating to age, parity, } \\
\text { literacy level, booking status, duration } \\
\text { and outcome of labour, mode of delivery } \\
\text { and cause of death were obtained from } \\
\text { casenotes and data were reviewed and } \\
\text { analyzed }\end{array}$ & $\begin{array}{l}\text { - } \quad \text { MMR } 4863 \text { per } 100,000 \text { livebirths } \\
\text { - } 46(23.4 \%) \text { of all maternal deaths were } \\
\text { adolescents (12-19 years old) } \\
\text { Eclampsia causes } 21 \text { (46\%) of the } \\
\text { adolescent maternal deaths }\end{array}$ \\
\hline $\begin{array}{l}\text { Akerele, J., Abhulimen, P., \& } \\
\text { Okonofua, F. (2001). Prevalence of } \\
\text { asymptomatic bacteriuria among } \\
\text { pregnant women in Benin City, } \\
\text { Nigeria. Journal of Obstetrics and } \\
\text { Gynaecology, 21(2), 141-144. }\end{array}$ & $\begin{array}{l}\text { Semi- } \\
\text { quantitative } \\
\text { screening }\end{array}$ & $\begin{array}{l}\text { ANC clinics in Benin } \\
\text { City } \\
500 \text { pregnant } \\
\text { women }\end{array}$ & $\mathrm{N} / \mathrm{A}$ & $\begin{array}{l}\text { Semi-quantitative culture of midstream } \\
\text { urine from pregnant women to screen } \\
\text { for asymptomatic bacteriuria in first } \\
\text { trimester. } \\
\text { Samples with significant bacteriuria } \\
\left(10^{5} \text { or more bacteria per ml) were }\right. \\
\text { examined under the light microscope } \\
\text { for: presence and number of red blood } \\
\text { cells, white blood cells, epithelial cells, } \\
\text { and casts. }\end{array}$ & $\begin{array}{l}\text { - } \quad \text { Rational therapy of asymptomatic } \\
\text { bacteriuria in pregnant women may } \\
\text { prevent associated risks such as } \\
\text { pyelonephritis and pre-eclampsia." } \\
\text { Of the } 500 \text { women screened, } 433 \\
\text { specimens showed significant bacteriuria. } \\
\text { - } \quad \text { nnote: this study did not report the } \\
\text { number of participants who developed } \\
\mathrm{PE} / \mathrm{E})]\end{array}$ \\
\hline $\begin{array}{l}\text { Akiibinu, M. O., Kolawole, T. O., } \\
\text { Ekun, O. A., \& Akiibinu, S. O. (2013). } \\
\text { Metabolic dysfunctions in Nigerian } \\
\text { pre-eclamptics. Archives of } \\
\text { Gynecology and Obstetrics, 288(5), } \\
\text { 1021-1026. }\end{array}$ & Case-control & $\begin{array}{l}32 \text { pregnant women } \\
\text { with pre-eclampsia } \\
\text { (cases) } \\
5 \text { months }\end{array}$ & & $\begin{array}{l}\text { Pre-eclamptic women were recruited } \\
\text { after } 20 \text { weeks. } \\
\text { Total antioxidant potential (TAP), total } \\
\text { plasma peroxides (TPP), total } \\
\text { cholesterol (TC), total protein (TP), } \\
\text { albumin, globulin, nitric oxide (NO), C- } \\
\text { reactive protein (CRP), total tri- } \\
\text { iodotyronine (TT3) and thyroid }\end{array}$ & $\begin{array}{l}\text { - Cases were defined as having } \\
\text { hypertension (systolic BP = } 169+26.0 \\
\mathrm{mmHg} \text {, diastolic }=102+11.0 \mathrm{mmHg}) \\
\text { significant proteinuria }(368+39 \mathrm{mg} / 24 \mathrm{~h} \text {, } \\
\text { severe headache, abdominal pain and } \\
\text { vomiting. } \\
\text { Weight, BMI, mean values of SBP, dBP } \\
\text { urinary protein, TSH, T3-CHOL, TPP, OSI, }\end{array}$ \\
\hline
\end{tabular}




\begin{tabular}{|c|c|c|c|c|c|}
\hline Citation & Study Design & $\begin{array}{l}\text { Location, } \\
\text { Timeframe, and } \\
\text { Sample size }\end{array}$ & $\begin{array}{l}\text { Prevalence } \\
\text { / } \\
\text { Incidence/ } \\
\text { CFR }\end{array}$ & Brief summary of Methods & $\begin{array}{l}\text { Main findings/ limitations } \\
\text { Conclusions/ } \\
\text { Recommendations }\end{array}$ \\
\hline & & $\begin{array}{l}40 \text { normal } \\
\text { pregnancies } \\
\text { (controls) }\end{array}$ & & $\begin{array}{l}\text { stimulating hormone (TSH) were } \\
\text { determined. } \\
\text { Oxidative stress index (OSI) was } \\
\text { calculated as the percent ratio of TPP } \\
\text { and TAP. }\end{array}$ & $\begin{array}{l}\text { MDA and CRP in pre-eclamptics were } \\
\text { significantly higher than in the controls. } \\
\text { Mean values of plasma TT3, albumin, TP } \\
\text { TAP and NO were significantly lower } \\
\text { among cases when compared with } \\
\text { controls. } \\
\text { Globulin showed no significant difference } \\
\text { between cases and controls } \\
\text { Results indicating that pre-eclamptics had } \\
\text { hypothyroidism, hypercholesterolemia, } \\
\text { oxidative stress and deranged } \\
\text { inflammatory responses. } \\
\text { Conclusion: hypercholesterolemia, } \\
\text { oxidative stress, deranged inflammatory } \\
\text { responses and lower thyroid function are } \\
\text { possible features of PE }\end{array}$ \\
\hline $\begin{array}{l}\text { Akinloye, O., Oyewale, O. J., \& } \\
\text { Oguntibeju, O. O. (2010). Evaluation } \\
\text { of trace elements in pregnant } \\
\text { women with pre-eclampsia. AFRICAN } \\
\text { JOURNAL OF BIOTECHNOLOGY, } \\
\text { 9(32), 5196-5202. }\end{array}$ & $\begin{array}{l}\text { Case control } \\
\text { study* } \\
\text { *the paper } \\
\text { itself claims to } \\
\text { be a 'cross- } \\
\text { sectional } \\
\text { randomized } \\
\text { study' }\end{array}$ & $\begin{array}{l}\text { Ladoke Akintola } \\
\text { University of } \\
\text { TechnologyTeaching } \\
\text { Hospital, Osogbo, } \\
\text { Osun State, Western } \\
\text { Nigeria } \\
49 \text { pre-eclamptic } \\
\text { patients (cases) } \\
40 \text { age-matched } \\
\text { non pre-eclamptic } \\
\text { women (controls) }\end{array}$ & & $\begin{array}{l}\text { Blood collection was done using a } \\
\text { sterile needle and syringe into } \\
\text { appropriate tube, each sample was } \\
\text { analyzed and zinc, copper, selenium, } \\
\text { manganese and magnesium levels were } \\
\text { determined }\end{array}$ & $\begin{array}{l}\text { All elements evaluated (zinc, copper, } \\
\text { selenium) were significantly lower in the } \\
\text { PE group when compared to the control } \\
\text { group. } \\
\text { Dietary supplementation of these } \\
\text { elements may help prevent PE } \\
\text { Mean BMI, systolic blood pressure and } \\
\text { diastolic blood pressure were all } \\
\text { significantly higher among cases than } \\
\text { controls } \\
\text { Mean serum concentrations of zinc, } \\
\text { copper, selenium, manganese and } \\
\text { magnesium were all significantly lower } \\
\text { among cases than controls } \\
\text { Suggests that PE is associated with } \\
\text { oxidative stress }\end{array}$ \\
\hline $\begin{array}{l}\text { Anorlu, R. I., Iwuala, N. C., \& Odum, } \\
\text { C. U. (2005). Risk factors for pre- } \\
\text { eclampsia in Lagos, Nigeria. } \\
\text { Australian and New Zealand Journal } \\
\text { of Obstetrics and Gynaecology, } \\
45(4), 278-282\end{array}$ & Case-control & $\begin{array}{l}\text { Lagos University } \\
\text { Teaching Hospital } \\
\text { February } 2001 \text { to } \\
\text { August } 2002 \\
1803 \text { women who } \\
\text { delivered during } \\
\text { study period }\end{array}$ & $\begin{array}{l}137 \text { of } \\
1803 \text { had } \\
\mathrm{PE} / \mathrm{E}(128 \\
\text { were } \\
\text { analyzed) } \\
\text { Incidence: } \\
7.6 \%\end{array}$ & $\begin{array}{l}\text { Socio-demographic characteristics, pre- } \\
\text { pregnancy weight, medical history and } \\
\text { previous obstetric history, and level of } \\
\text { stress at home and at work was } \\
\text { collected during face-to-face interviews }\end{array}$ & 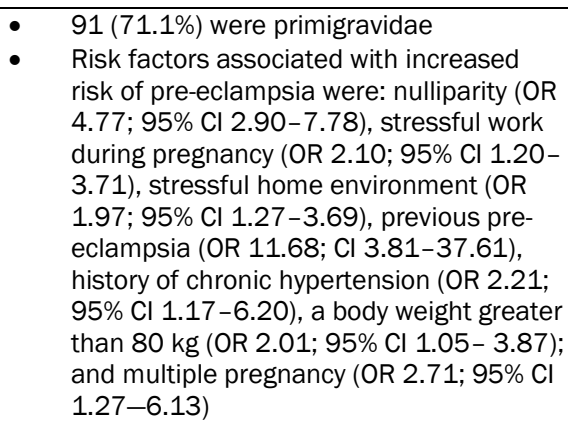 \\
\hline
\end{tabular}




\begin{tabular}{|c|c|c|c|c|c|}
\hline Citation & Study Design & $\begin{array}{l}\text { Location, } \\
\text { Timeframe, and } \\
\text { Sample size }\end{array}$ & $\begin{array}{l}\text { Prevalence } \\
/ \\
\text { Incidence/ } \\
\text { CFR }\end{array}$ & Brief summary of Methods & $\begin{array}{l}\text { Main findings/ limitations } \\
\text { Conclusions/ } \\
\text { Recommendations }\end{array}$ \\
\hline $\begin{array}{l}\text { Arinola, G., Arowojolu, A., Bamgboye, } \\
\text { A., Akinwale, A., \& Adeniyi, A. (2006). } \\
\text { Serum concentrations of } \\
\text { immunoglobulins and acute phase } \\
\text { proteins in Nigerian women with } \\
\text { preeclampsia. Reproductive Biology, } \\
6(3), 265-27\end{array}$ & & $\begin{array}{l}\text { Obstetrics and } \\
\text { Gynaecology Clinic } \\
\text { of the University } \\
\text { College Hospital, } \\
\text { Ibadan, Oyo State, } \\
\text { Nigeria } \\
92 \text { women 15-30 } \\
\text { years old }\end{array}$ & & $\begin{array}{l}\text { Participants divided into three groups: } \\
\text {--32 pregnant women in } 3^{\text {rd }} \text { trimester } \\
\text { with preeclampsia } \\
\text {--36 pregnant women in } 3^{\text {rd }} \text { trimester } \\
\text { without preeclampsia } \\
\text {-24 non-pregnant women with no } \\
\text { history of abortion as controls } \\
\text { Blood and urine samples were taken } \\
\text { and analyzed for: immunoglobulin } \\
\text { classes (IgA, IgG, and IgM) and acute } \\
\text { phase proteins (alpha-2-macroglobulin, } \\
\text { haptoglobin and transferrin). } \\
\text { Mean of two readings for each } \\
\text { specimen were taken as actual value }\end{array}$ & $\begin{array}{l}\text { - Diagnosis of PE was done based on: } \\
\text { significant proteinuria (>100mg/day) and } \\
\text { high blood pressure }(>130 / 90 \mathrm{mmHg}) \text { on } \\
\text { at least two occasions } 6 \text { hours apart or } \\
\text { more. } \\
\text { - Mean level of IgG was significantly lower } \\
\text { in subjects with preeclampsia and } \\
\text { significantly higher in patients with normal } \\
\text { pregnancy when compared to non- } \\
\text { pregnant controls. } \\
\text { Mean level of lgA was significantly } \\
\text { reduced in pre-eclamptic subjects vs. } \\
\text { controls } \\
\text { Mean levels of transferrin and alpha-2- } \\
\text { macroglobulin were significantly lower } \\
\text { and among PE group compared with other } \\
\text { two groups. } \\
\text { Haptoglobin was significantly higher in } \\
\text { women with PE compared to normal } \\
\text { pregnancy, but both pregnant groups had } \\
\text { lower levels compared with non-pregnant } \\
\text { women. }\end{array}$ \\
\hline $\begin{array}{l}\text { Atiba, A. S., Abbiyesuku, F. M., } \\
\text { 'Niran-atiba, T. A., Oparinde, D. P., } \\
\text { Ajose, O. A., \& Akindele, R. A. (2014). } \\
\text { Free radical attack on membrane } \\
\text { lipid and antioxidant vitamins in the } \\
\text { course of pre-eclamptic pregnancy. } \\
\text { Ethiopian Journal of Health } \\
\text { Sciences, 24(1), 35-42. }\end{array}$ & $\begin{array}{l}\text { Longitudinal } \\
\text { prospective } \\
\text { cohort }\end{array}$ & $\begin{array}{l}\text { Ladoke Akintola } \\
\text { University of } \\
\text { Technology } \\
\text { Teaching Hospital, } \\
\text { Osogbo and } \\
\text { Egbedore Local } \\
\text { Government Health } \\
\text { Centre, Awo, Osun } \\
\text { state, Nigeria } \\
\text { May } 2011 \text {-January } \\
2012 \\
118 \text { pre-eclamptic } \\
\text { and } 115 \text { apparently } \\
\text { normal pregnant } \\
\text { women were } \\
\text { recruited }\end{array}$ & & $\begin{array}{l}100 \text { women for each of the three study } \\
\text { groups (PE, normal pregnancy (NP), } \\
\text { nonpregnant (NoP)) participated in } \\
\text { baseline and follow up eight weeks } \\
\text { later. } \\
\text { Venous blood was collected from } \\
\text { pregnant participants and nonpregnant } \\
\text { controls. Plasma was separated and } \\
\text { used for malondialdehyde (MDA) and } \\
\text { vitamins C and E analysis. }\end{array}$ & $\begin{array}{l}\text { - } \quad \text { Pre-eclamptic women were defined as } \\
\text { having elevated BP of } 140 / 90 \text { mmHg on } \\
\text { two consecutive recordings } 4 \text { to } 6 \text { hours } \\
\text { apart, minimum proteinuria of } 300 \text { gm in } \\
24 \text { hour urine sample or } 1+\text { on dipstick. } \\
\text { Highest levels of MDA were in PE patients } \\
\text { and lowest in NoP patients; MDA among } \\
\text { PE patients was also higher than NP } \\
\text { during the second and third trimesters. } \\
\text { No change in plasma levels of vitamins C } \\
\text { and E was found as pregnancy advances } \\
\text { Studies needed to identify the specific } \\
\text { antioxidant to counteract lipid } \\
\text { peroxidation (free radical injury) which } \\
\text { may help reduce PE. }\end{array}$ \\
\hline
\end{tabular}




\begin{tabular}{|c|c|c|c|c|c|}
\hline Citation & Study Design & $\begin{array}{l}\text { Location, } \\
\text { Timeframe, and } \\
\text { Sample size }\end{array}$ & $\begin{array}{l}\text { Prevalence } \\
/ \\
\text { Incidence/ } \\
\text { CFR }\end{array}$ & Brief summary of Methods & $\begin{array}{l}\text { Main findings/ limitations } \\
\text { Conclusions/ } \\
\text { Recommendations }\end{array}$ \\
\hline & & $\begin{array}{l}\text { Age matched non } \\
\text { pregnant women }\end{array}$ & & & \\
\hline $\begin{array}{l}\text { Attahir, A., Sufiyan, M. B., Salihu, A., } \\
\& \text { Rabiu, a M. (2010). Association } \\
\text { between Maternal Socio - economic } \\
\text { Status, Polygamy and Risk of Pre - } \\
\text { eclampsia in Rural Areas of Northern } \\
\text { Nigeria. Journal of Family and } \\
\text { Reproductive Health, 4(1), 47-52. }\end{array}$ & Case control & $\begin{array}{l}\text { Primary Health } \\
\text { Centers in Katsina, } \\
\text { Adamawa and Borno } \\
\text { states } \\
\text { Two groups of } 50 \\
\text { each: } \\
\text { A--Pregnant non- } \\
\text { hypertensive women } \\
\text { B-women with pre- } \\
\text { eclampsia }\end{array}$ & & $\begin{array}{l}\text { BP was measured and questionnaire } \\
\text { was administered to each patient to } \\
\text { assess the association between various } \\
\text { social factors and risk of PE }\end{array}$ & $\begin{array}{l}\text { - If PE progresses to eclampsia, } \\
\text { characterized by malignant hypertension } \\
\text { and epileptiform convulsions, caesarian } \\
\text { section is required. } \\
\text { Known risk factors: nulliparity, history of } \\
\text { pre-eclampsia in previous pregnancy, } \\
\text { extremes of maternal age, multi fetal } \\
\text { gestation, chronic hypertension, diabetes } \\
\text { mellitus, chronic kidney disease, vascular } \\
\text { or connective tissue disease, } \\
\text { thrombophilia, high Body Mass Index } \\
\text { (BMI), and obesity. } \\
\text { Family history of hypertension, diabetes or } \\
\text { kidney disease was more common among } \\
\text { women with PE } \\
\text { Seclusion and polygamy were not found to } \\
\text { have an effect on risk of developing PE } \\
\text { The women with PE were more likely to be } \\
\text { uneducated, lack income, which could } \\
\text { lead to low ANC attendance among this } \\
\text { population }\end{array}$ \\
\hline $\begin{array}{l}\text { Awodu, O. A., Shokunbi, W. A., \& } \\
\text { Ejele, O. A. (2003). Lupus } \\
\text { anticoagulant in Nigerian women } \\
\text { with preeclampsia. West African } \\
\text { Journal of Medicine, 22(3), 240- } \\
242 .\end{array}$ & Case control & $\begin{array}{l}\text { University of Benin } \\
\text { Teaching Hospital } \\
26 \text { pregnant } \\
\text { women, 18-45 years } \\
\text { old with PE } \\
50 \text { apparently } \\
\text { healthy pregnant } \\
\text { women, 18-45 years } \\
\text { old }\end{array}$ & & $\begin{array}{l}\text { Blood samples were collected and } \\
\text { platelet poor plasma was prepared and } \\
\text { preserved for testing/analysis. } \\
\text { Kaolin clotting time (KCT) was done to } \\
\text { test coagulation } \\
\text { Lupus anticoagulant was determined to } \\
\text { be present if the KCT ratio at } 20 \% \text { test } \\
\text { plasma to KCT at } 100 \% \text { normal control } \\
\text { plasma } \geq 1.2\end{array}$ & $\begin{array}{l}\text { - This study found } 15.4 \% \text { prevalence of } \\
\text { lupus anticoagulant in women with PE } \\
\text { which is statistically higher than the } \\
\text { prevalence of LA in apparently healthy } \\
\text { pregnancies. (it is controversial as to } \\
\text { whether LA presence is causal or } \\
\text { consequence of clinical manifestations } \\
\text { with which it has been associated) } \\
\text { This study recommends that LA in PE in } \\
\text { Nigeria is significant and all women } \\
\text { should be screened for LA. }\end{array}$ \\
\hline $\begin{array}{l}\text { Chigbu, C. O., Okezie, O. A., \& Odugu, } \\
\text { B. U. (2009). Women in southern } \\
\text { Nigeria with change in paternity do } \\
\text { not have increased incidence of pre- } \\
\text { eclampsia. Journal of Obstetrics and } \\
\text { Gynaecology: The Journal of the } \\
\text { Institute of Obstetrics and }\end{array}$ & $\begin{array}{l}\text { Prospective } \\
\text { cohort }\end{array}$ & $\begin{array}{l}\text { Catholic Maternity } \\
\text { Hospital, Moniaya, } \\
\text { Ogoja, Cross River } \\
\text { State, Nigeria } \\
\text { September 2006- } \\
\text { August } 2007\end{array}$ & & $\begin{array}{l}\text { Women attending ANC clinic of the } \\
\text { hospital for their second pregnancy } \\
\text { were recruited, sociodemographic and } \\
\text { obstetric data was collected including } \\
\text { paternity of index and previous } \\
\text { pregnancies, outcome of previous }\end{array}$ & $\begin{array}{l}\text { - The "exposure" for this cohort study was } \\
\text { change in paternity } \\
\text { PE was defined as hypertension } \\
(>140 / 90 \mathrm{mmHg} \text { on at least two } \\
\text { occasions at least } 6 \mathrm{~h} \text { apart or dBP of } \\
110 \mathrm{mmHg} \text { at any time or an increase of } \\
30 \mathrm{mmHg} \text { and } 15 \mathrm{mmHg} \text { in sBP and dBP } \\
\text { respectively or mean arterial pressure of }\end{array}$ \\
\hline
\end{tabular}




\begin{tabular}{|c|c|c|c|c|c|}
\hline Citation & Study Design & $\begin{array}{l}\text { Location, } \\
\text { Timeframe, and } \\
\text { Sample size }\end{array}$ & $\begin{array}{l}\text { Prevalence } \\
/ \\
\text { Incidence/ } \\
\text { CFR }\end{array}$ & Brief summary of Methods & $\begin{array}{l}\text { Main findings/ limitations } \\
\text { Conclusions/ } \\
\text { Recommendations }\end{array}$ \\
\hline Gynaecology, 29(2), 94-97. & & $\begin{array}{l}779 \text { women were } \\
\text { recruited and } 732 \\
\text { were included in the } \\
\text { final analysis due to } \\
\text { loss to follow up }\end{array}$ & & $\begin{array}{l}\text { pregnancy and duration of sexual } \\
\text { cohabitation with present partner. } \\
\text { Urine protein was measured using } \\
\text { dipstick testing and ANC follow up was } \\
\text { every four weeks until } 28 \text { weeks } \\
\text { gestation and every two weeks after that } \\
\text { until } 37 \text { weeks. }\end{array}$ & $\begin{array}{l}\text { greater than } 105 \mathrm{mmHg} \text { ) with proteinuria } \\
\text { after } 20 \text { weeks of pregnancy } \\
312 \text { (group A) had change in paternity; } \\
420 \text { had no change in paternity (group B) } \\
\text { - The rate of PE was not significantly } \\
\text { different between the two groups, within } \\
\text { Group A, duration of cohabitation did not } \\
\text { show significant difference between those } \\
\text { who developed PE and those who did not. } \\
\text { "the findings of this study call for a re- } \\
\text { examination of the "change in paternity } \\
\text { theory of pre-eclampsia"” }\end{array}$ \\
\hline $\begin{array}{l}\text { Enaruna, N., Ande, A., \& Okpere, E. } \\
\text { (2013). Clinical significance of low } \\
\text { serum magnesium in pregnant } \\
\text { women attending the University of } \\
\text { Benin Teaching Hospital. Nigerian } \\
\text { Journal of Clinical Practice, 16(4), } \\
\text { 448-53. }\end{array}$ & $\begin{array}{l}\text { Prospective } \\
\text { cohort }\end{array}$ & $\begin{array}{l}\text { University of Benin } \\
\text { Teaching Hospital, } \\
\text { Benin City } \\
\text { June-December } \\
2011 \\
160 \text { patients }\end{array}$ & & $\begin{array}{l}\text { Participants (included antenatal women } \\
\text { recruited in } 2^{\text {nd }} \text { trimester and followed } \\
\text { up until } 1 \text { week postpartum) had blood } \\
\text { drawn at recruitment to measure serum } \\
\text { magnesium and were followed up until } \\
\text { delivery when repeat serum magnesium } \\
\text { assay was done }\end{array}$ & 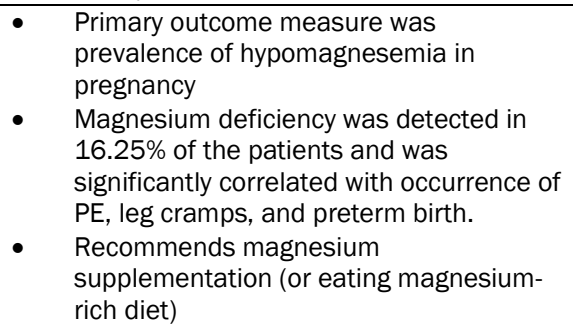 \\
\hline $\begin{array}{l}\text { Familoni, O. B., Adefuye, P. O., \& } \\
\text { Olunuga, T. O. (2004). Pattern and } \\
\text { factors affecting the outcome of } \\
\text { pregnancy in hypertensive patients. } \\
\text { Journal of the National Medical } \\
\text { Association, 96(12), 1626-1631. }\end{array}$ & $\begin{array}{l}\text { Retrospective } \\
\text { cohort }\end{array}$ & $\begin{array}{l}\text { Olabisi Onabanjo } \\
\text { University Teaching } \\
\text { Hospital, Sagamu } \\
\text { January 1997- } \\
\text { December } 2002 \\
\text { 2,393 deliveries }\end{array}$ & $\begin{array}{l}\text { HDP } \\
\text { incidence: } \\
5.3 \%\end{array}$ & $\begin{array}{l}\text { Medical records of pregnant patients } \\
\text { were analyzed, } 127 \text { were identified as } \\
\text { having a hypertensive disorder of } \\
\text { pregnancy (HDP). } \\
\text { Based on hypertension type, patients } \\
\text { were categories as "high-risk" or "low- } \\
\text { risk" the groups were compared }\end{array}$ & $\begin{array}{l}\text { 26.2\% had gestational hypertension, } \\
19.7 \% \text { had pre-eclampsia superimposed } \\
\text { on chronic hypertension and } 54.1 \% \text { had } \\
\text { PE/E. } \\
\text { Those with PE/E had the worst maternal } \\
\text { and fetal outcomes (6.1\% maternal } \\
\text { mortality, } 18.2 \% \text { target organ damage, } \\
36.4 \% \text { fetal mortality, } 66.7 \% \text { fetal } \\
\text { respiratory distress) } \\
62(50.8 \%) \text { were high-risk and } 60(49.2 \% \\
\text { were low-risk } \\
\text { - High-risk group had higher rates of: } \\
\text { illiteracy, maternal death, stroke, } \\
\text { abruptio, fetal death, and caesarean } \\
\text { section and lower rates of regular ANC. } \\
\text { Parity had no effect on whether the } \\
\text { patient was high- or low-risk }\end{array}$ \\
\hline $\begin{array}{l}\text { Glew, R. H., Cole, D. M., Mehla, G. S., } \\
\text { El-Nafaty, A. U., Crossey, M. J., }\end{array}$ & Case control & $\begin{array}{l}\text { Federal Medical } \\
\text { Centre, Gombe and }\end{array}$ & N/A & $\begin{array}{l}\text { Pregnant women were placed into one } \\
\text { of four groups: Group 1: PE; Group 2: }\end{array}$ & $\begin{array}{l}\text { PE was defined as BP } 140 / 90 \mathrm{mmHg} \text { or } \\
\text { greater and proteinuria }(>190 \mathrm{mg} / \mathrm{g} \\
\text { creatinine) }\end{array}$ \\
\hline
\end{tabular}




\begin{tabular}{|c|c|c|c|c|c|}
\hline Citation & Study Design & $\begin{array}{l}\text { Location, } \\
\text { Timeframe, and } \\
\text { Sample size }\end{array}$ & $\begin{array}{l}\text { Prevalence } \\
/ \\
\text { Incidence/ } \\
\text { CFR }\end{array}$ & Brief summary of Methods & $\begin{array}{l}\text { Main findings/ limitations } \\
\text { Conclusions/ } \\
\text { Recommendations }\end{array}$ \\
\hline $\begin{array}{l}\text { Tzamaloukas, A., \& VanderJagt, D. J. } \\
\text { (2005). Lysosomal enzymes in } \\
\text { preeclamptic women in northern } \\
\text { Nigeria. Clinica Chimica Acta; } \\
\text { International Journal of Clinical } \\
\text { Chemistry, 353(1-2), 95-101. }\end{array}$ & & $\begin{array}{l}\text { Specialist Hospital, } \\
\text { Gombe } \\
\text { June-August } 2001 \\
\text { Group 1: } 41 \text { women } \\
\text { Group 2: } 31 \text { women } \\
\text { Group 3: } 44 \text { women } \\
\text { Group 4: } 52 \text { women }\end{array}$ & & $\begin{array}{l}\text { hypertensive aproteinuric; group } \\
\text { 3:normotensive proteinuric; group 4: } \\
\text { healthy pregnant women (controls) } \\
\text { Urine specimens were collected and } \\
\text { underwent biochemical analyses. } \\
\text { Results were statistically analyzed }\end{array}$ & $\begin{array}{l}\text { The goal was to assess whether lysosomal } \\
\text { enzyme concentrations in women with PE } \\
\text { were due to the hypertension or } \\
\text { proteinuria, or both. } \\
\text { This study found that low levels of } \beta \text { - } \\
\text { hexosaminidase in pre-eclamptic women } \\
\text { is associated with proteinuria and not } \\
\text { hypertension; it is not likely, therefore, } \\
\text { that screening for lysosomal enzymes } \\
\text { would be useful in predicting or } \\
\text { monitoring PE. }\end{array}$ \\
\hline $\begin{array}{l}\text { Glew, R. H., Melah, G., El-Nafaty, A. } \\
\text { l., Brandt, Y., Morris, D., \& } \\
\text { VanderJagt, D. J. (2004). Plasma } \\
\text { and urinary free amino acid } \\
\text { concentrations in preeclamptic } \\
\text { women in northern Nigeria. Clinica } \\
\text { Chimica Acta; International Journal } \\
\text { of Clinical Chemistry, 342(1-2), } \\
\text { 179-185. }\end{array}$ & Case control & $\begin{array}{l}\text { Federal Medical } \\
\text { Centre, Gombe and } \\
\text { Specialist Hospital, } \\
\text { Gombe } \\
37 \text { pre-eclamptic } \\
\text { women } \\
16 \text { controls }\end{array}$ & & $\begin{array}{l}\text { Urine and blood samples were taken } \\
\text { and analyzed for amino acids. } \\
\text { Statistical analyses were performed to } \\
\text { compare variables between patients } \\
\text { with PE and controls }\end{array}$ & $\begin{array}{l}\text { - Defined "pre-eclamptic" as: cerebral or } \\
\text { visual disturbances, epigastric pain, } \\
\text { pulmonary edema or cyanosis, sBP > } \\
140 \mathrm{mmHg} \text { or dBP }>90 \mathrm{mmHg} \text { and } \\
\text { proteinuria (190mg total protein/g } \\
\text { creatinine or more) } \\
\text { - Serum concentrations of common amino } \\
\text { acids (including serum arginine) were not } \\
\text { significantly different between study } \\
\text { groups, except phenylalanine. } \\
\text { - Phenylalanine concentration was } \\
\text { significantly higher among PE group }\end{array}$ \\
\hline $\begin{array}{l}\text { Guerrier, G., Oluyide, B., Keramarou, } \\
\text { M., \& Grais, R. F. (2013). Factors } \\
\text { associated with severe preeclampsia } \\
\text { and eclampsia in Jahun, Nigeria. } \\
\text { International Journal of Women's } \\
\text { Health, 5(1), 509-513. }\end{array}$ & $\begin{array}{l}\text { Hospital-based } \\
\text { case control } \\
\text { study }\end{array}$ & $\begin{array}{l}\text { Jahun Hospital } \\
\text { October 2010-May } \\
2011 \\
2,835 \text { pregnant } \\
\text { women } \\
\text { 1,257: normal } \\
\text { pregnancy (controls) } \\
\text { 419: Severe PE/E } \\
\text { (cases) }\end{array}$ & $\begin{array}{l}16 \% \text { had } \\
\text { severe } \\
\text { PE/E (175: } \\
\text { severe PE, } \\
\text { and } 244: \\
\text { eclampsia) }\end{array}$ & $\begin{array}{l}\text { Participants were selected from the } \\
\text { emergency obstetric program in the } \\
\text { rural Jahun hospital, patients were } \\
\text { interviewed and gave demographic } \\
\text { information, medical history, social } \\
\text { history, current history, use of traditional } \\
\text { treatments, delivery details and } \\
\text { neonatal outcome. }\end{array}$ & $\begin{array}{l}\text { Eclampsia is the occurrence of seizure } \\
\text { and/or altered level of consciousness not } \\
\text { caused by epilepsy or other convulsive } \\
\text { disorders, with signs of severe } \\
\text { preeclampsia. } \\
\text { Severe PE : new hypertension with blood } \\
\text { pressure of } 160 \mathrm{mmHg} \text { systolic or } \\
\text { diastolic BP of } 110 \mathrm{mmHg} \text { or greater, } \\
\text { after } 20 \text { weeks of gestation in a woman } \\
\text { who was normotensive before } 20 \text { weeks, } \\
\text { associated with proteinuria } \\
\text { Of } 244 \text { eclamptic cases, } 194 \text { were ante- } \\
\text { and intra-partum, and } 50 \text { were admitted } \\
\text { postpartum; } 11 \% \text { experienced no signs of } \\
\text { severe hypertension (headache, blurred } \\
\text { vision) } \\
\text { The groups were similar except for: the } \\
\text { cases were younger (mean age } 21 \text { vs } \\
\text { mean age } 25 \text { among controls), a higher }\end{array}$ \\
\hline
\end{tabular}




\begin{tabular}{|c|c|c|c|c|c|}
\hline Citation & Study Design & $\begin{array}{l}\text { Location, } \\
\text { Timeframe, and } \\
\text { Sample size }\end{array}$ & $\begin{array}{l}\text { Prevalence } \\
/ \\
\text { Incidence/ } \\
\text { CFR }\end{array}$ & Brief summary of Methods & $\begin{array}{l}\text { Main findings/ limitations } \\
\text { Conclusions/ } \\
\text { Recommendations }\end{array}$ \\
\hline & & & & & $\begin{array}{l}\text { proportion attended fewer than four ANC } \\
\text { visits ( } 79 \% \text { vs } 73 \% \text { ) } \\
63 \% \text { used traditional treatments during } \\
\text { their pregnancy (herbal medicines to treat } \\
\text { bleeding, ease abdominal pain, or for } \\
\text { rupture of the amniotic sac) } \\
\text { Cases were statistically more likely to } \\
\text { have cesarean section, longer hospital } \\
\text { stay, stillbirth or neonatal death. } \\
\text { Use of herbal treatment was not found to } \\
\text { increase the risk of developing severe } \\
\text { PE/E. }\end{array}$ \\
\hline $\begin{array}{l}\text { Idogun, E. S., Imarengiaye, C. O., \& } \\
\text { Momoh, S. M. (2007). Extracellular } \\
\text { calcium and magnesium in } \\
\text { preeclampsia and eclampsia. } \\
\text { African Journal of Reproductive } \\
\text { Health, 11(2), 89-94. }\end{array}$ & Cross sectional & $\begin{array}{l}\text { University of Benin } \\
\text { Teaching Hospital, } \\
\text { Nigeria } \\
11 \text { patients } \\
23 \text { controls, }\end{array}$ & N/A & $\begin{array}{l}\text { Patients were randomly selected from } \\
\text { among hospital attendees, "patients" } \\
\text { were women presenting with PE (or } \\
\mathrm{PE} / \mathrm{E} \text { ) in their third trimester who were } \\
\text { going for caesarean section; those on } \\
\mathrm{MgSO}_{4} \text { and calcium lactate drugs were } \\
\text { excluded. Controls were normotensive } \\
\text { pregnant women, also going for CS. } \\
\text { Blood was taken from participants, and } \\
\text { plasma was harvested and analyzed for } \\
\text { calcium, magnesium and electrolyte and } \\
\text { urea estimations; cerebrospinal fluid } \\
\text { (CSF) was taken during lumbar puncture } \\
\text { for spinal anaesthesia and calcium and } \\
\text { magnesium estimations were made. }\end{array}$ & $\begin{array}{l}\text { - Plasma calcium was significantly higher in } \\
\text { controls vs. patients but there was no } \\
\text { significant difference between groups for } \\
\text { plasma magnesium levels. } \\
\text { Calcium CSF and magnesium CSF were } \\
\text { significantly lower in patients than in } \\
\text { controls } \\
\text { - Lower levels of magnesium and calcium } \\
\text { may have an effect on PE/E }\end{array}$ \\
\hline $\begin{array}{l}\text { Ikechukwu, I. C., Ojareva, O. I. A., } \\
\text { Ibhagbemien, A. J., Okhoaretor, O. F., } \\
\text { Oluwatomi, O. B., Akhalufo, O. S., ... } \\
\text { Chigaekwu, M. N. (2012). Blood } \\
\text { lead, calcium, and phosphorus in } \\
\text { women with preeclampsia in Edo } \\
\text { State, Nigeria. Archives of } \\
\text { Environmental \& Occupational } \\
\text { Health, 67(3), 163-169. }\end{array}$ & Cohort & $\begin{array}{l}\text { Irrua Specialist } \\
\text { Teaching Hospital } \\
\text { Irrua, Edo State, } \\
\text { Nigeria } \\
\\
\text { November 2006- } \\
\text { September } 2008\end{array}$ & & $\begin{array}{l}\text { Women aged } 20-35 \text { attending ANC clinic } \\
\text { at the hospital. Women with history of } \\
\text { any chronic disease and glycosuria were } \\
\text { excluded. } \\
\text { Medical histories were taken and } \\
\text { recorded in duplicate by doctors who } \\
\text { were unaware of the goal of the study. }\end{array}$ & $\begin{array}{ll}- & \text { PE was defined as SBP > } 140 \mathrm{mmHG} \\
\text { and/or DBP }>90 \mathrm{mmHg} \text { and proteinuria } \\
\text { during at least two visits after 22nd week } \\
\text { of gestation. } \\
150 \text { normal pregnant women and } 59 \text { with } \\
\text { preeclampsia } \\
\text { Blood lead levels were significantly higher } \\
\text { in women with PE than normal pregnant } \\
\text { women and serum calcium and inorganic } \\
\text { phosphorus were significantly lower than } \\
\text { in normal pregnant women. } \\
\text { A possible explanation for the increase in } \\
\text { blood lead in PE women vs normal }\end{array}$ \\
\hline
\end{tabular}




\begin{tabular}{|c|c|c|c|c|c|}
\hline Citation & Study Design & $\begin{array}{l}\text { Location, } \\
\text { Timeframe, and } \\
\text { Sample size }\end{array}$ & $\begin{array}{l}\text { Prevalence } \\
\text { / } \\
\text { Incidence/ } \\
\text { CFR }\end{array}$ & Brief summary of Methods & $\begin{array}{l}\text { Main findings/ limitations } \\
\text { Conclusions/ } \\
\text { Recommendations }\end{array}$ \\
\hline & & $\begin{array}{l}283 \text { pregnant } \\
\text { women, } 74 \text { excluded } \\
\text { for noncompliance } \\
209 \text { nonpregnant } \\
\text { controls }\end{array}$ & & $\begin{array}{l}\text { BP was measured, protein and sugar } \\
\text { levels tested in urine. Blood samples } \\
\text { were taken from each participant at } \\
\text { delivery and analyzed for calcium and } \\
\text { phosphorus determination and blood } \\
\text { lead determination. }\end{array}$ & $\begin{array}{l}\text { pregnant women is a possible increase in } \\
\text { maternal bone lead mobilization. } \\
\text { Elevated blood lead levels may contribute } \\
\text { to the development of PE }\end{array}$ \\
\hline $\begin{array}{l}\text { Ikpen, M. A., Eigbefoh, J., Eifediyi, R. } \\
\text { A., Isabu, P. A., Okogbenin, S., } \\
\text { Okogbo, F. O., ... Ekwedigwe, K. C. } \\
\text { (2012). Determination of antioxidant } \\
\text { status of pre-eclamptic and } \\
\text { normotensive sub-rural Nigerian } \\
\text { pregnant women at the Irrua } \\
\text { Specialist Teaching Hospital, Irrua, } \\
\text { Edo State. The Journal of Maternal- } \\
\text { Fetal \& Neonatal Medicine, 25(10), } \\
\text { 2046-2050. }\end{array}$ & $\begin{array}{l}\text { prospective } \\
\text { case-control } \\
\text { study }\end{array}$ & $\begin{array}{l}\text { Antenatal clinics, } \\
\text { antenatal and } \\
\text { labour wards, } \\
\text { Accident and } \\
\text { Emergency unit of } \\
\text { Irrua Specialist } \\
\text { Teaching Hosptal, } \\
\text { Irrua, Edo State. }\end{array}$ & & $\begin{array}{l}\text { Eighty cases and } 80 \text { matched controls } \\
\text { were recruited into the study. } \\
\text { Cases: booked pregnant women with PE } \\
\text { Controls: gestational age and parity } \\
\text { matched normotensive pregnant women } \\
\text { Blood samples were taken from all } \\
\text { participants and analyzed for vitamins C } \\
\text { and E. }\end{array}$ & $\begin{array}{l}\text { - Two consecutive BP measurements of } \\
>140.90 \mathrm{mmHg} 4 \text { hours apart after } 20 \text { th } \\
\text { week and significant proteinuria }(>2+) \text { or } \\
1+\text { if the specific gravity was }<1.030 \text { and } \\
\text { pH was }<8 \text {. } \\
\text { Plasma vitamin } \mathrm{C} \text { and E levels were } \\
\text { significantly lower in cases than in } \\
\text { controls. } \\
\text { Role of antioxidants in pathogenesis of PE } \\
\text { is inconclusive, but may be an opportunity } \\
\text { to prevent PE }\end{array}$ \\
\hline $\begin{array}{l}\text { Isezuo, S. A., \& Ekele, B. A. (2004). } \\
\text { Eclampsia and abnormal QTc. West } \\
\text { African Journal of Medicine, 23(2), } \\
\text { 123-127. }\end{array}$ & $\begin{array}{l}\text { Prospective } \\
\text { case control }\end{array}$ & $\begin{array}{l}\text { Usman Danfodiyo } \\
\text { University Teaching } \\
\text { Hospital, Sokoto, } \\
\text { Nigeria } \\
\text { August } 2001 \text { and } \\
\text { July } 2002 \\
30 \text { patients }\end{array}$ & & $\begin{array}{l}30 \text { consecutive patients with } \\
\text { intrapartum eclampsia were included in } \\
\text { the study. } \\
\text { General information was obtained as } \\
\text { well as medical history. BP was } \\
\text { measured three times at rest and the } \\
\text { average of the last two were taken as } \\
\text { the BP. } \\
\text { Electrocardiogram (ECG) was recorded } \\
\text { during the intrapartum period to } \\
\text { measure QT interval }\end{array}$ & $\begin{array}{l}\text { - } \quad \text { Eclampsia is characterized by generalized } \\
\text { convulsion, elevated BP and proteinuria } \\
\text { with or without oedema occurring after } 20 \\
\text { weeks gestation. } \\
\text { QT interval is the "total time from the } \\
\text { onset of ventricular depolarization to the } \\
\text { completion of repolarization" } \\
\text { Cases had higher mean heart rate, higher } \\
\text { frequency of sinus tachycardia and } \\
\text { significantly higher QTc. } \\
\text { - This study found that eclampsia is } \\
\text { associated with hypocalcaemia, abnormal } \\
\text { QTc and T-axis deviation; serum } \\
\text { magnesium did not differ significantly } \\
\text { between study groups }\end{array}$ \\
\hline $\begin{array}{l}\text { Leone, S., Res, J. B., No, V., O, O. V., } \\
\text { S, A. A., Adewumi, A., \& Olalekan, A. } \\
\text { (2009). Homocysteine Levels in } \\
\text { Nigerian Women with Pre-eclampsia } \\
\text { / Eclampsia. Sierra Leone Journal of } \\
\text { Biomedical Research, 1(1), 55-60. }\end{array}$ & Case control & $\begin{array}{l}\text { Lagos University } \\
\text { Teaching Hospital, } \\
\text { Idi-Araba } \\
\text { January-October } \\
2006\end{array}$ & & $\begin{array}{l}\text { "all participants were to strictly maintain } \\
\text { the drug regimen prescribed for routine } \\
\text { antenatal use only" } \\
\text { Venous blood was collected and plasma } \\
\text { levels of homocysteine were determined }\end{array}$ & $\begin{array}{l}\text { - Rising homocysteine level in eclamptics } \\
\text { was significantly associated with blood } \\
\text { pressure levels. } \\
\text { Plasma homocysteine levels in the 3rd } \\
\text { trimester of pregnancy is significantly } \\
\text { higher among eclamptic women than } \\
\text { those who have a normal pregnancy. }\end{array}$ \\
\hline
\end{tabular}




\begin{tabular}{|c|c|c|c|c|c|}
\hline Citation & Study Design & $\begin{array}{l}\text { Location, } \\
\text { Timeframe, and } \\
\text { Sample size }\end{array}$ & $\begin{array}{l}\text { Prevalence } \\
\text { / } \\
\text { Incidence/ } \\
\text { CFR }\end{array}$ & Brief summary of Methods & $\begin{array}{l}\text { Main findings/ limitations } \\
\text { Conclusions/ } \\
\text { Recommendations }\end{array}$ \\
\hline & & $\begin{array}{l}100 \text { primigravidae } \\
\text { women (60 lost to } \\
\text { follow up, or } \\
\text { incomplete data) } \\
25 \text { eclamptic } \\
\text { women } \\
25 \text { non pregnant } \\
\text { women }\end{array}$ & & $\begin{array}{l}\text { at registration, at } 26 \text { weeks and at } 34 \\
\text { weeks gestation for all participants. }\end{array}$ & $\begin{array}{l}\text { Mean corpuscular volume, plasma } \\
\text { homocysteine level and rising blood } \\
\text { pressure during pregnancy may help } \\
\text { predict development of PE/E. }\end{array}$ \\
\hline $\begin{array}{l}\text { Nwobodo, E. I., Panti, A., \& A, N. E. P. } \\
\text { (2012). Adolescent maternal } \\
\text { mortality in North-west Nigeria. West } \\
\text { African Journal of Medicine, 31(4), } \\
224-226 .\end{array}$ & $\begin{array}{l}\text { Review of } \\
\text { hospital case } \\
\text { records }\end{array}$ & $\begin{array}{l}\text { Usmanu Danfodiyo } \\
\text { University Teaching } \\
\text { Hospital (UDUTH), } \\
\text { Sokoto } \\
\text { January 2000- } \\
\text { December } 2009 \\
\text { 2,047 live births } \\
\text { among adolescents }\end{array}$ & & $\begin{array}{l}\text { Case reports of live births for women } \\
15-19 \text { years old were collected and } \\
\text { reviewed. Demographic and other } \\
\text { health data were extracted and } \\
\text { analyzed. }\end{array}$ & $\begin{array}{l}165 \text { maternal deaths among adolescent } \\
\text { mothers: MMR = 5415 per 100,000 live } \\
\text { births } \\
\text { Main cause of death was eclampsia: } \\
53.9 \% \\
\text { - } \quad \text { ANC allows for early detection of PIH } \\
\text { which can prevent the progression to } \\
\text { eclampsia }\end{array}$ \\
\hline $\begin{array}{l}\text { Okafor, U. V, \& Ezegwui, H. U. } \\
\text { (2010). Cesarean delivery in } \\
\text { preeclampsia and seasonal variation } \\
\text { in a tropical rainforest belt. Journal } \\
\text { of Postgraduate Medicine, 56(1), } \\
21-23 .\end{array}$ & $\begin{array}{l}\text { Retrospective } \\
\text { record review }\end{array}$ & $\begin{array}{l}\text { University of Nigeria } \\
\text { Teaching Hospital, } \\
\text { Enugu } \\
\text { July } 1996 \text {-June } \\
2006 \\
6798 \text { deliveries, } \\
1579 \text { CS deliveries } \\
196 \text { had toxemia of } \\
\text { pregnancy (166: PE } \\
\text { and 30: eclampsia) }\end{array}$ & & $\begin{array}{l}\text { Records for patients presenting for CS } \\
\text { with PE/E during rainy and dry seasons } \\
\text { were reviewed, and demographics and } \\
\text { obstetric history and outcome were } \\
\text { extracted and analyzed. }\end{array}$ & $\begin{array}{l}\text { - The primary objective of this study was to } \\
\text { assess whether or not seasonality in a } \\
\text { tropical rainforest belt had an effect on } \\
\text { the presentation of preeclamptics } \\
\text { undergoing cesarean section. } \\
\text { - Among preeclampsia, } 115 \text { had CS during } \\
\text { rainy season, } 52 \text { during dry season. } \\
\text { Among those with eclampsia, } 26 \\
\text { presented during rainy season and } 4 \\
\text { during dry season } \\
\text { This study found a "systemic seasonal } \\
\text { variability in the need for cesarean } \\
\text { delivery for preeclamptics with a peak } \\
\text { during the rainy season" }\end{array}$ \\
\hline $\begin{array}{l}\text { Olayemi, O., Strobino, D., Adedapo, } \\
\text { K., Aimakhu, C., Odukogbe, A.-T., \& } \\
\text { Salako, B. (2010). Influence of } \\
\text { previous abortions and new } \\
\text { paternity on the risk of hypertension } \\
\text { in nulliparous parturients in Ibadan: }\end{array}$ & $\begin{array}{l}\text { Prospective } \\
\text { cohort }\end{array}$ & $\begin{array}{l}\text { University College } \\
\text { Hospital (UCH) and } \\
\text { Adeoyo Maternity } \\
\text { Hospital (AMH), } \\
\text { Ibadan }\end{array}$ & $\begin{array}{l}\text { Hypertensi } \\
\text { on in } \\
\text { pregnancy } \\
\text { incidence: } \\
33 \%\end{array}$ & $\begin{array}{l}\text { Nulliparous women were recruited } \\
\text { before } 20 \text { weeks gestation. For the } \\
\text { baseline data, participants were } \\
\text { interviewed about: sociobiological } \\
\text { variables, history of previous abortions, } \\
\text { sexual history, and family history of }\end{array}$ & $\begin{array}{l}\text { - At AMH, } 76.5 \% \text { of the participants } \\
\text { reported a prior abortion, but only } 20.4 \% \\
\text { reported same paternity abortion } \\
\text { At UCH, } 64.9 \% \text { reported prior abortion, } \\
\text { and } 31.5 \% \text { reported same paternity } \\
\text { abortion }\end{array}$ \\
\hline
\end{tabular}




\begin{tabular}{|c|c|c|c|c|c|}
\hline Citation & Study Design & $\begin{array}{l}\text { Location, } \\
\text { Timeframe, and } \\
\text { Sample size }\end{array}$ & $\begin{array}{l}\text { Prevalence } \\
\text { / } \\
\text { Incidence/ } \\
\text { CFR }\end{array}$ & Brief summary of Methods & $\begin{array}{l}\text { Main findings/ limitations } \\
\text { Conclusions/ } \\
\text { Recommendations }\end{array}$ \\
\hline $\begin{array}{l}\text { a cohort study. The Journal of } \\
\text { Obstetrics and Gynaecology } \\
\text { Research, 36(5), 965-969. }\end{array}$ & & $\begin{array}{l}2000 \text { patients } \\
\text { (1000 at each site) }\end{array}$ & & $\begin{array}{l}\text { hypertension and BP and urine protein } \\
\text { were also measured. } \\
\text { Within } 48 \text { hours of delivering the final } \\
\text { interview was conducted, BP measured } \\
\text { and urine tested. }\end{array}$ & $\begin{array}{l}\text { "There was no statistical difference in the } \\
\text { incidence of hypertension among } \\
\text { participants with previous abortion (32.98 } \\
\text { vs } 33.10 \mathrm{P}=0.962) " \\
\text { - Nor was there a statistical difference in } \\
\text { the development of hypertension } \\
\text { regarding change in paternity; } 30.12 \% \text { of } \\
\text { women reporting same paternity } \\
\text { abortions and } 34.10 \% \text { without same } \\
\text { paternity abortions developed } \\
\text { hypertension ( } \mathrm{p}=0.164 \text { ) } \\
\text { The authors suggest researching } \\
\text { presentation of human leukocyte antigen } \\
\text { (HLA) from semen prior to conception to } \\
\text { reduce incidence of eclampsia. }\end{array}$ \\
\hline $\begin{array}{l}\text { Olayemi, O., Strobino, D., Aimakhu, } \\
\text { C., Adedapo, K., Kehinde, A., } \\
\text { Odukogbe, A.-T., \& Salako, B. } \\
\text { (2010). Influence of duration of } \\
\text { sexual cohabitation on the risk of } \\
\text { hypertension in nulliparous } \\
\text { parturients in Ibadan: A cohort study. } \\
\text { The Australian \& New Zealand } \\
\text { Journal of Obstetrics \& Gynaecology, } \\
50(1), 40-44 .\end{array}$ & $\begin{array}{l}\text { Prospective } \\
\text { cohort }\end{array}$ & $\begin{array}{l}\text { University College } \\
\text { Hospital (UCH) and } \\
\text { Adeoyo Maternity } \\
\text { Hospital (AMH), and } \\
\text { Oluyoro Catholic } \\
\text { Hospital }(\mathrm{OCHH}) \text {, } \\
\text { Ibadan } \\
\text { AMH: } 900 \text { women } \\
\text { UCH: } 950 \text { women } \\
\text { OCH: } 780\end{array}$ & $\begin{array}{l}\text { Gestational } \\
\text { hypertensi } \\
\text { on } \\
\text { incidence: } \\
28.93 \% \\
\text { PE } \\
\text { incidence } \\
4.13 \%\end{array}$ & $\begin{array}{l}\text { Nulliparous women were recruited } \\
\text { before } 20 \text { weeks gestation. For the } \\
\text { baseline data, participants were } \\
\text { interviewed about: sociobiological } \\
\text { variables, history of previous abortions, } \\
\text { sexual history, and family history of } \\
\text { hypertension and BP and urine protein } \\
\text { were also measured. } \\
\text { Within } 48 \text { hours of delivering the final } \\
\text { interview was conducted, BP measured } \\
\text { and urine tested. }\end{array}$ & $\begin{array}{l}\text { - } 29.64 \% \text { reported having had previous } \\
\text { abortion, and } 25.92 \% \text { were same } \\
\text { paternity abortions } \\
\text { This study found that incidence of } \\
\text { hypertension was higher among those } \\
\text { who had had abortions (29.40\%) than } \\
\text { those who had not ( } 28.52 \%) \\
\text { Change in paternity did not have a } \\
\text { significant impact on incidence of } \\
\text { hypertension } \\
\text { Multivariate analysis found that length of } \\
\text { sexual cohabitation was protective } \\
\text { against hypertension ( } 4 \% \text { decline in risk of } \\
\text { developing hypertension for every month } \\
\text { increase in cohabitation). } \\
\text { This multivariate model controlling for } \\
\text { age, BMl, educational attainment and } \\
\text { family history of hypertension found that } \\
\text { same paternity abortions were protective } \\
\text { (HR 0.46, Cl 0.22-0.96) but previous } \\
\text { abortion alone was not. } \\
\text { The early timing of previous abortions } \\
\text { (first trimester) would account for no } \\
\text { observe protective feature of abortions in } \\
\text { this study (when other studies have } \\
\text { shown abortions to be protective }\end{array}$ \\
\hline $\begin{array}{l}\text { Olusanya, B. O. (2011). Perinatal } \\
\text { outcomes of multiple births in } \\
\text { southwest Nigeria. Journal of Health, }\end{array}$ & $\begin{array}{l}\text { Retrospective } \\
\text { cross-sectional } \\
\text { review of }\end{array}$ & $\begin{array}{l}\text { Island Maternity } \\
\text { Hospital, Lagos }\end{array}$ & & $\begin{array}{l}\text { Participants were included in this study } \\
\text { from a prospectively recruited cohort of }\end{array}$ & $\begin{array}{l}\text { This study's primary objective was } \\
\text { determine perinatal outcomes that may } \\
\text { influence neurodevelopment adversely } \\
\text { among multiple gestations; the relevance }\end{array}$ \\
\hline
\end{tabular}




\begin{tabular}{|c|c|c|c|c|c|}
\hline Citation & Study Design & $\begin{array}{l}\text { Location, } \\
\text { Timeframe, and } \\
\text { Sample size }\end{array}$ & $\begin{array}{l}\text { Prevalence } \\
/ \\
\text { Incidence/ } \\
\text { CFR }\end{array}$ & Brief summary of Methods & $\begin{array}{l}\text { Main findings/ limitations } \\
\text { Conclusions/ } \\
\text { Recommendations }\end{array}$ \\
\hline $\begin{array}{l}\text { Population, and Nutrition, 29(6), } \\
639-647 .\end{array}$ & $\begin{array}{l}\text { hospital } \\
\text { records }\end{array}$ & $\begin{array}{l}\text { May 2005- } \\
\text { December } 2007\end{array}$ & & $\begin{array}{l}\text { newborns under a separate program on } \\
\text { universal newborn hearing screening. } \\
\text { This study defined "hypertensive } \\
\text { disorders" as pre-eclampsia, eclampsia } \\
\text { and pregnancy-induced hypertension }\end{array}$ & $\begin{array}{l}\text { for our study is that Olusanya's study } \\
\text { indicated that multiple gestation is } \\
\text { associated with an increased risk of } \\
\text { hypertensive disorders. } \\
\text { This study found that mothers with } \\
\text { multiple gestations (twins or triplets in } \\
\text { this case, no higher-order births occurred } \\
\text { during the study period) were significantly } \\
\text { more likely to have had hypertensive } \\
\text { disorders. } \\
\text { 268/4,416 (6\%) of singleton births were } \\
\text { associated with hypertensive disorders } \\
\text { compared to: } 26 / 157(16.5 \%) \text { multiple } \\
\text { gestations }\end{array}$ \\
\hline $\begin{array}{l}\text { Onah, H. (2002). Prognostic value of } \\
\text { absolute versus relative rise of blood } \\
\text { pressure in pregnancy. African } \\
\text { Journal of Reproductive Health, 6(1), } \\
32-40 \text {. }\end{array}$ & cohort & $\begin{array}{l}\text { Department of } \\
\text { Obstetrics and } \\
\text { Gynaecology, } \\
\text { University of Nigeria } \\
\text { Teaching Hospital, } \\
\text { Enugu } \\
\text { December 17, } \\
1997-\text { March 31, } \\
1999 \\
515 \text { women (7\% } \\
\text { incomplete: } 478 \\
\text { participants) }\end{array}$ & & $\begin{array}{l}\text { Longitudinal measurement of BP, } \\
\text { anthropometric data and MMR in study } \\
\text { population (heathy ANC subjects). } \\
\text { Participants were recruited prior to } 16 \\
\text { weeks gestation. Fundal height, weight, } \\
\text { height, BP, and presence or absence of } \\
\text { proteinuria were recorded } \\
\text { Participants were categorized into } \\
\text { groups: } \\
\text { A: relative diastolic blood pressure } \\
\text { (DBP) rise from the averaged } 16-20 \\
\text { weeks readings until delivery }< \\
\text { 15mmHg and absolute DBP }<90 \mathrm{mmHg} \\
\text { B: relative DBP rise } \geq 15 \mathrm{mmHg} \text { and } \\
\text { absolute DBP }<90 \mathrm{mmHg} \\
\text { C: absolute DBP } \geq 90 \mathrm{mmHg} \text { no matter } \\
\text { the relative rise in BP } \\
\text { Analysis was also done with groups } \\
\text { based on systolic BP (using } 140 \mathrm{mmHg} \\
\text { as the threshold rate and } 30 \mathrm{mmHg} \text { as } \\
\text { the relative rise amount) }\end{array}$ & $\begin{array}{l}\text { - } 478 \text { of the } 515 \text { women completed the } \\
\text { study. } \\
\text { Diagnosing hypertension from a relative } \\
\text { rise in DBP of } 15 \mathrm{mmHg} \text { included } 48 \% \text { of } \\
\text { subjects who had normal pregnancies. } \\
\text { These relative rises in BP could indicate } \\
\text { that closer surveillance is required. } \\
\text { This study found that maternal and fetal } \\
\text { outcomes were not significantly affected } \\
\text { by the relative rise in DBP (as long as DBP } \\
\text { <90mmHg) } \\
\text { Strict eligibility criteria meant many were } \\
\text { excluded (women booked after } 16 \text { weeks, } \\
\text { delivered preterm, etc) } \\
\text { The data in this study suggest that } \\
\text { absolute blood pressure (140/90 mmHg) } \\
\text { is a better predictor of feto-maternal } \\
\text { outcome than relative rise measurements } \\
\text { in systolic or diastolic pressures. } \\
\text { - } \quad\end{array}$ \\
\hline
\end{tabular}




\begin{tabular}{|c|c|c|c|c|c|}
\hline Citation & Study Design & $\begin{array}{l}\text { Location, } \\
\text { Timeframe, and } \\
\text { Sample size }\end{array}$ & $\begin{array}{l}\text { Prevalence } \\
\text { / } \\
\text { Incidence/ } \\
\text { CFR }\end{array}$ & Brief summary of Methods & $\begin{array}{l}\text { Main findings/ limitations } \\
\text { Conclusions/ } \\
\text { Recommendations }\end{array}$ \\
\hline $\begin{array}{l}\text { Osungbade, K., Oginni, S., Olumide, } \\
\text { A., K, O., Oginni, S., \& Olumide, A. } \\
\text { (2008). Content of antenatal care } \\
\text { services in secondary health care } \\
\text { facilities in Nigeria: implication for } \\
\text { quality of maternal health care. } \\
\text { INTERNATIONAL JOURNAL FOR } \\
\text { QUALITY IN HEALTH CARE, 2O(5), } \\
\text { 346-351. }\end{array}$ & Cross-sectional & $\begin{array}{l}\text { Osun state } \\
\text { N/A } \\
390 \text { ANC clients }\end{array}$ & & $\begin{array}{l}\text { Antenatal care exit interview forms from } \\
\text { the Safe Motherhood Needs } \\
\text { Assessment package was used to } \\
\text { collect information from } 390 \text { pregnant } \\
\text { women leaving ANC visits. }\end{array}$ & $\begin{array}{l}\text { - All of the women in this study had their } \\
\text { blood pressure checked which is an } \\
\text { important screening tool for detecting } \\
\text { hypertension and toxaemia (now called } \\
\text { PE) } \\
\text { At the hospitals, } 48.6 \% \text { of the } 284 \text { women } \\
\text { and } 28.3 \% \text { of } 106 \text { at Health Centers had } \\
\text { their urine checked for protein levels } \\
\text { This study concluded that the screening } \\
\text { services and care were reasonably } \\
\text { capable of addressing pre-eclampsia and } \\
\text { early detection of some fetal problems but } \\
\text { they were insufficient for detecting long- } \\
\text { standing pre-eclampsia and other } \\
\text { conditions (detecting and treating severe } \\
\text { anemia and preventing complications of } \\
\text { malaria in pregnancy). }\end{array}$ \\
\hline $\begin{array}{l}\text { Owolabi, A., AO, F., Kuti, O., Adeyemi, } \\
\text { A., Faturoti, S., \& Obiajuwa, P. } \\
\text { (2008). Maternal complications and } \\
\text { perinatal outcomes in booked and } \\
\text { unbooked Nigerian mothers. } \\
\text { Singapore Medical Journal, 49(7), } \\
526-531 .\end{array}$ & $\begin{array}{l}\text { Prospective } \\
\text { case control }\end{array}$ & $\begin{array}{l}\text { Wesley Guild } \\
\text { Hospital Unit, llesa, } \\
\text { Nigeria (Obafemi } \\
\text { Awolowo University } \\
\text { Teaching Hospitals } \\
\text { Complex) } \\
\text { August 2004-May } \\
2006 \\
\text { 1,154 deliveries }\end{array}$ & & $\begin{array}{l}\text { Outcomes of pregnancies booked for } \\
\text { ANC were compared to outcomes of } \\
\text { women who were unbooked }\end{array}$ & $\begin{array}{l}\text { - } \quad 29 \%(n=336) \text { were unbooked } \\
\text { Unbooked mothers were more likely to be } \\
\text { younger, unmarried, have lower education } \\
\text { and social status, higher proportion of } \\
\text { multipara, experience antepartum } \\
\text { haemorrhage, anemia and PE/E } \\
\text { 7.9\% of unbooked women developed } \\
\text { PE/E compared to } 2.1 \% \text { of booked } \\
\text { mothers (OR 1.71, 1.15-2.55) }\end{array}$ \\
\hline $\begin{array}{l}\text { Salako, B. L., Olayemi, O., Odukogbe, } \\
\text { A.-T. A., Adedapo, K. S., Aimakhu, C. } \\
\text { O., Alu, F. E., \& Ola, B. (2003). } \\
\text { Microalbuminuria in pregnancy as a } \\
\text { predictor of preeclampsia and } \\
\text { eclampsia. West African Journal of } \\
\text { Medicine, 22(4), 295-300. }\end{array}$ & Cohort & $\begin{array}{l}\text { University College } \\
\text { Hospital (UCH) } \\
\text { Ibadan } \\
93 \text { healthy } \\
\text { normotensive } \\
\text { pregnant women ( }\end{array}$ & & $\begin{array}{l}\text { During initial booking, BP and urinalysis } \\
\text { was conducted and } 100 \text { women who } \\
\text { were normotensive were recruited and } \\
\text { had urinalysis completed. } \\
\text { PE: BP of } 140 / 90 \mathrm{mmHg} \text { or more or a } \\
\text { rise of } 30 \mathrm{mmHg} \text { in systolic BP or } \\
15 \mathrm{mmHg} \text { in diastolic BP (measured two } \\
\text { times, six hours apart, at rest) } \\
\text { associated with proteinuria. }\end{array}$ & $\begin{array}{l}\text { - } \\
\text { Ninety-three delivered at UCH, two had } \\
\text { spontaneous abortion and five delivered } \\
\text { elsewhere. } \\
\text { At booking } 61.3 \% \text { ( } 57 \text { patients) had } \\
\text { normal albumin excretion and } 22(23.7 \%) \\
\text { had microalbuminuria and } 12(15 \%) \text { had } \\
\text { gross microalbuminuria. } \\
\text { This study found that there was a } \\
\text { statistically significant difference in } \\
\text { incidence of PE with an increase in } \\
\text { albumin excretion. } \\
\text { Microabuminuria was found to predict } \\
\text { preeclampsia with high sensitivity but with } \\
\text { low positive predictive value } \\
\text { (overestimated the number of cases) }\end{array}$ \\
\hline
\end{tabular}




\begin{tabular}{|c|c|c|c|c|c|}
\hline Citation & Study Design & $\begin{array}{l}\text { Location, } \\
\text { Timeframe, and } \\
\text { Sample size }\end{array}$ & $\begin{array}{l}\text { Prevalence } \\
/ \\
\text { Incidence/ } \\
\text { CFR }\end{array}$ & Brief summary of Methods & $\begin{array}{l}\text { Main findings/ limitations } \\
\text { Conclusions/ } \\
\text { Recommendations }\end{array}$ \\
\hline $\begin{array}{l}\text { Salako, B., Odukogbe, A., Olayemi, } \\
\text { O., Adedapo, K., \& Aimakhu, C. } \\
\text { (2003). Serum albumin, creatinine, } \\
\text { uric acid and hypertensive disorders } \\
\text { of pregnancy. East African Medical } \\
\text { Journal, } 80(8), 424-428 .\end{array}$ & Cohort & $\begin{array}{l}\text { University College } \\
\text { Hospital }(\mathrm{UCH}) \\
\text { Ibadan } \\
23 \text { healthy } \\
\text { normotensive } \\
\text { primigravidae } \\
\text { singleton pregnant } \\
\text { women }\end{array}$ & & $\begin{array}{l}59 \text { women were recruited into the study } \\
\text { when they booked for ANC prior to } 20 \\
\text { weeks gestation at the facility and were } \\
\text { included in analysis if they delivered at } \\
\text { the facility as well. These women were } \\
\text { followed throughout their pregnancies. } \\
\text { All participants gave complete clinical } \\
\text { history, had BP measured and urinalysis } \\
\text { done. } \\
\text { Analysis of serum samples was } \\
\text { performed as well (at a lab) }\end{array}$ & $\begin{array}{l}\text { - } \quad \text { Of the } 59 \text { women recruited, two had } \\
\text { abortions, } 13 \text { did not attend the minimum } \\
\text { required number of prenatal clinic visits } \\
\text { and } 21 \text { did not deliver at UCH. } \\
23 \text { completed the study; five (21.7\%) had } \\
\text { PE, two (8.7\%) had pregnancy-induced } \\
\text { hypertension and } 16(69.6 \%) \text { remained } \\
\text { normotensive. } \\
\text { Oedema and proteinuria were mild in all } \\
\text { cases of PE, one of the cases of PE died. } \\
\text { This study found that there was no } \\
\text { significant difference in uric acid and } \\
\text { creatinine levels between the groups, but } \\
\text { mean serum albumin concentration was } \\
\text { significantly higher in the PE group. } \\
\text { Based on the findings of this study: serum } \\
\text { uric acid and creatinine concentrations } \\
\text { early in pregnancy are not useful to } \\
\text { predict subsequent development of PE/E } \\
\text { Mean serum albumin levels early in } \\
\text { pregnancy could be useful in predicting } \\
\text { subsequent PE-further research is } \\
\text { needed. To define the value of estimation. }\end{array}$ \\
\hline $\begin{array}{l}\text { Vanderjagt DJ, Patel RJ, El-Nafaty } \\
\text { AU, Melah GS, Crossey MJ, Glew RH. } \\
\text { High-density lipoprotein and } \\
\text { homocysteine levels correlate } \\
\text { inversely in preeclamptic women in } \\
\text { northern Nigeria. Acta Obstet } \\
\text { Gynecol Scand. Denmark; } 2004 \\
\text { Jun;83(6):536-42. }\end{array}$ & Case control & $\begin{array}{l}\text { Federal Medical } \\
\text { Center or the } \\
\text { Specialist Hospital, } \\
\text { Gombe } \\
\text { June-August } 2001 \\
43 \text { cases with PE/E } \\
130 \text { controls }\end{array}$ & $\mathrm{N} / \mathrm{A}$ & $\begin{array}{l}\text { Participants were recruited while } \\
\text { attending the facilities. The cases were } \\
\text { diagnosed with } \mathrm{PE} / \mathrm{E} \text { if they had systolic } \\
\text { BP greater than } 140 \mathrm{mmHg} \text {, diastolic BP } \\
\text { greater than } 90 \mathrm{mmHg} \text {, proteinuria in } \\
\text { excess } 190 \mathrm{mg} \text { total protein/g } \\
\text { creatinine, and edema. Blood samples } \\
\text { were taken from all participants and } \\
\text { serum cholesterol concentration, serum } \\
\text { HDL-cholesterol concentration, and } \\
\text { serum triacylglycerol concentration were } \\
\text { measured. }\end{array}$ & 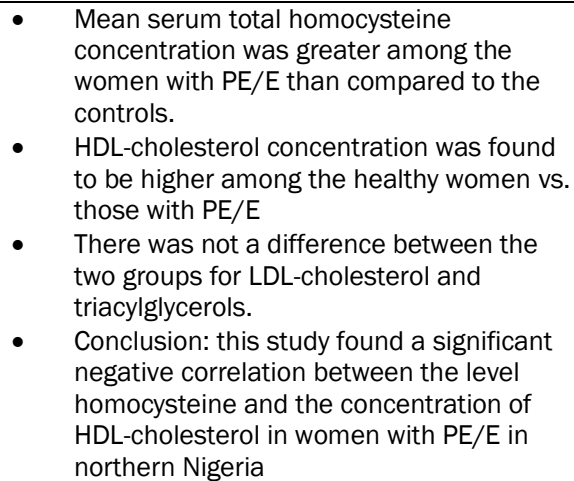 \\
\hline
\end{tabular}




\section{Appendix V:}

\section{SUMMARY TABLES OF OTHER HEALTH OUTCOMES ASSOCIATED WITH PE/E}

\begin{tabular}{|c|c|c|c|c|}
\hline Citation & Study Design & $\begin{array}{l}\text { Location, Timeframe, } \\
\text { and Sample size }\end{array}$ & Brief summary of Methods & $\begin{array}{l}\text { Main findings/ limitations } \\
\text { Conclusions/ } \\
\text { Recommendations }\end{array}$ \\
\hline $\begin{array}{l}\text { ADEBAMI, O. J., OYEDEJI, G. A., OWA, J. A., \& } \\
\text { OYELAMI, O. A. (2007). Maternal factors in the } \\
\text { etiology of fetal malnutrition in Nigeria. } \\
\text { Pediatrics International, } 49(2), 150-155 .\end{array}$ & Prospective & $\begin{array}{l}\text { Neonatal and } \\
\text { Maternity Units of the } \\
\text { Wesley Guild Hospital } \\
\text { Ilesa, Nigeria, a unit } \\
\text { of Obafemi Awolowo } \\
\text { University Teaching } \\
\text { Hospitals Complex, } \\
\text { lle-Ife } \\
\text { January - August } \\
2001 \\
473 \text { consecutive, } \\
\text { singleton, live birth, } \\
\text { term (37-42 weeks } \\
\text { gestation) neonates" }\end{array}$ & $\begin{array}{l}\text { Maternal prenatal records were } \\
\text { reviewed, additional history } \\
\text { collected from mother. Babies were } \\
\text { classified into 'babies with FM' and } \\
\text { 'babies without FM' and the two } \\
\text { groups were compared. }\end{array}$ & $\begin{array}{l}\text { - The study found that } 27 \% \text { of babies with FM were } \\
\text { born to mothers with PIH/eclampsia compared to } \\
\text { 3.6\% of babies without FM from mothers with } \\
\text { PIH/eclampsia } \\
\text { "Hypertension and pre-eclampsia induce fibrinoid } \\
\text { degeneration of arteriolar media with resultant } \\
\text { intimal thickening and decreased luminal diameter. } \\
\text { It causes permeability of essential nutrient across } \\
\text { the placental barrier to the fetal and has, therefore, } \\
\text { been implicated as a causative factor of FM" }\end{array}$ \\
\hline $\begin{array}{l}\text { Adekanle, D., \& Akinbile, T. (2012). } \\
\text { Eclampsia and Pregnancy Outcome at } \\
\text { Lautech Teaching Hospital, Osogbo, } \\
\text { SouthWest, Nigeria. Clinics in Mother } \\
\text { and Child Health, 9(1). }\end{array}$ & $\begin{array}{l}\text { Descriptive, } \\
\text { cross- } \\
\text { sectional } \\
\text { retrospective } \\
\text { review }\end{array}$ & $\begin{array}{l}\text { Ladoke Akintola } \\
\text { University of } \\
\text { Technology Teaching } \\
\text { Hospital, Osogbo, } \\
\text { South West, Nigeria } \\
\text { January 1, 2005- } \\
\text { December 31, 2010 }\end{array}$ & $\begin{array}{l}\text { Review of case notes of women } \\
\text { who had eclampsia } \\
\text { Eclampsia defined as: "systolic } \\
\text { blood pressure of } \geq 140 \mathrm{mmHg} \text {, } \\
\text { diastolic blood pressure of } 90 \\
\mathrm{mmHg} \text {, proteinuria of at least } 1 \\
\text { plus and convulsions in patients } \\
\text { with no background history of } \\
\text { seizure disorder were retrieved. }\end{array}$ & 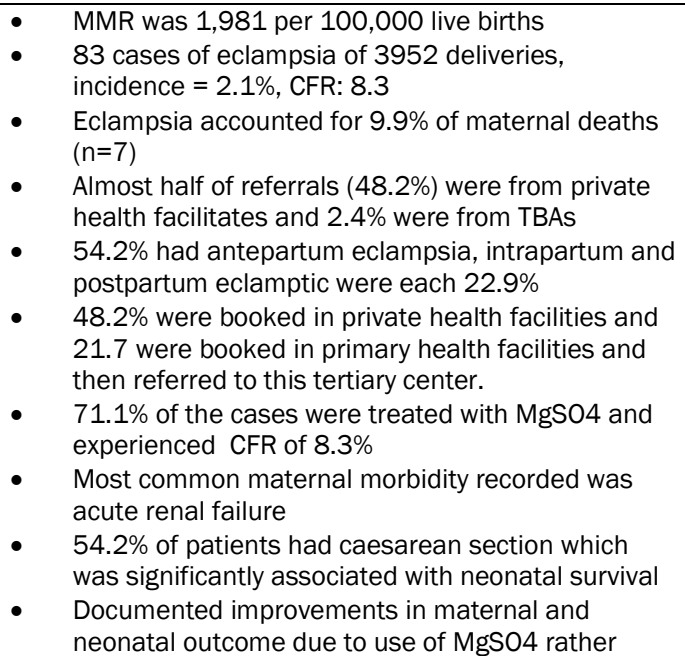 \\
\hline
\end{tabular}




\begin{tabular}{|c|c|c|c|c|}
\hline Citation & Study Design & $\begin{array}{l}\text { Location, Timeframe, } \\
\text { and Sample size }\end{array}$ & Brief summary of Methods & $\begin{array}{l}\text { Main findings/ limitations } \\
\text { Conclusions/ } \\
\text { Recommendations }\end{array}$ \\
\hline & & & & $\begin{array}{l}\text { than diazepam, unavailability of MgSO4 supplies- } \\
\text { often due to cost-is likely a contributor to poor } \\
\text { outcome }\end{array}$ \\
\hline $\begin{array}{l}\text { Adeyemo, W. L., Rabiu, K. A., Okoturo, T. } \\
\text { M., Adebanjo, A. A., Adewunmi, A. A., \& } \\
\text { Adeyemi, M. O. (2012). Orofacial injuries } \\
\text { associated with eclampsia in patients } \\
\text { presenting at a Nigerian Tertiary } \\
\text { Hospital. Journal of Obstetrics and } \\
\text { Gynaecology, January 20(32), 54-57. }\end{array}$ & $\begin{array}{l}\text { Prospective } \\
\text { case review }\end{array}$ & $\begin{array}{l}\text { Lagos State } \\
\text { University Teaching } \\
\text { Hospital } \\
\text { December 2008- } \\
\text { November 2009 } \\
107 \text { patients } \\
\text { presented with } \\
\text { eclampsia }\end{array}$ & $\begin{array}{l}\text { For women arriving at the facility } \\
\text { with eclampsia, a proforma was } \\
\text { designed to collect: age, parity, } \\
\text { history of ANC, \# of eclamptic fits, } \\
\text { presence/absence of orofacial } \\
\text { injuries and morbidity/mortality } \\
\text { associated with eclampsia. In } \\
\text { cases of orofacial injury, further } \\
\text { details were collected as to the } \\
\text { nature and cause of the injury }\end{array}$ & $\begin{array}{l}\text { - } 45 \text { patients (42\%) with eclampsia presented with } \\
\text { orofacial injuries. Injuries were most often on the } \\
\text { tongue and/or lips } \\
\text { Injury in most cases ( } n=16 \text { ) was caused by } \\
\text { relatives forcing hard objects into patient's mouth } \\
\text { or biting down during convulsions. } \\
\text { - } \quad \text { Six patients were injured due to a fall. } \\
\text { - } 98 \% \text { were not booked for ANC at this facility and } \\
\text { were only referred after developing eclampsia } \\
\text { Patients who received ANC from TBAs and at } \\
\text { churches were significantly more likely to have } \\
\text { orofacial injuries }\end{array}$ \\
\hline $\begin{array}{l}\text { Alhassan, M., Anyiam, C., Bosan, I., } \\
\text { Danbauchi, S., David, S., \& Isa, M. } \\
\text { (2008). Role of pre-eclamptic toxaemia } \\
\text { or eclampsia in hypertensive women } \\
\text { attending cardiac clinic of Ahmadu Bello } \\
\text { University Teaching Hospital Zaria, } \\
\text { Nigeria. Annals of African Medicine, } \\
\text { 7(3), 133-137. }\end{array}$ & $\begin{array}{l}\text { Cross- } \\
\text { sectional }\end{array}$ & $\begin{array}{l}\text { Cardiac Clinic of } \\
\text { Ahmadu Bello } \\
\text { University Teaching } \\
\text { Hospital, Zaria, } \\
\text { Nigeria } \\
50 \text { consecutive adult } \\
\text { female hypertensive } \\
\text { patients }\end{array}$ & $\begin{array}{l}\text { all patients provided demographic } \\
\text { and clinical characterization from } \\
\text { history and physical examination } \\
49 \text { of the } 50 \text { patients recruited } \\
\text { were studied. }\end{array}$ & $\begin{array}{l}\text { - Those who had PE in a previous pregnancy } \\
\text { developed hypertension an average of } 8.42+7.69 \\
\text { years after the pregnancy and for those without PE, } \\
12.76+8.90 \text { years. (no statistically significant } \\
\text { difference) } \\
\text { - } \quad \text { Of the } 49 \text { participants, } 32.7 \% \text { had previous PE } \\
\text { Of those who had previous PE, } 43.8 \% \text { had } \\
\text { complications of hypertension including: } \\
\text { hypertensive heart disease, hypertensive heart } \\
\text { failure, cerebrovascular accident, and peripartum } \\
\text { cardiac failure. }\end{array}$ \\
\hline $\begin{array}{l}\text { Faponle, A., \& Makinde, O. (2007). } \\
\text { Caesarean section: Intra-operative blood } \\
\text { loss and its restitution. East African } \\
\text { Medical Journal, 84(1), 31-34. }\end{array}$ & $\begin{array}{l}\text { Prospective } \\
\text { study }\end{array}$ & $\begin{array}{l}\text { Obafemi Awolowo } \\
\text { University Teaching } \\
\text { Hospitals Complex, } \\
\text { lle-Ife, Nigeria } \\
\text { January 1, 2005- } \\
\text { December } 2005 \\
641 \text { patients who } \\
\text { underwent caesarean } \\
\text { section }\end{array}$ & $\begin{array}{l}\text { The following was collected for all } \\
\text { caesarean sections at the facility } \\
\text { during the study period: } \\
\text { Demographics, American Society of } \\
\text { Anaesthesiologists grading, } \\
\text { coexisting conditions, presence of } \\
\text { clinical anaemia, indication for } \\
\text { Caesarean section, pre-operative } \\
\text { packed cell volume, surgical } \\
\text { details. }\end{array}$ & $\begin{array}{l}\text { - } \quad \mathrm{PE} / \mathrm{E} \text { were cited as indication for } 9.4 \%(\mathrm{n}=60) \text { of } \\
\text { the caesarean sections } \\
\text { Pre-eclampsia "carried the expected increased } \\
\text { transfusion and major blood loss risk" }\end{array}$ \\
\hline $\begin{array}{l}\text { Geidam, A. D., Audu, B. M., Kawuwa, B. M., \& } \\
\text { Obed, J. Y. (2009). Rising trend and indications } \\
\text { of caesarean section at the university of }\end{array}$ & $\begin{array}{l}\text { Retrospective } \\
\text { review }\end{array}$ & $\begin{array}{l}\text { University of } \\
\text { Maiduguri Teaching } \\
\text { Hospital }\end{array}$ & $\begin{array}{l}\text { Retrospective analysis of } \\
\text { caesarean sections performed. }\end{array}$ & $\begin{array}{l}\text { - 1,192 caesarean sections were performed during } \\
\text { the study period, } 79.4 \% \text { of which were emergency } \\
\text { C/S }\end{array}$ \\
\hline
\end{tabular}




\begin{tabular}{|c|c|c|c|c|}
\hline Citation & Study Design & $\begin{array}{l}\text { Location, Timeframe, } \\
\text { and Sample size }\end{array}$ & Brief summary of Methods & $\begin{array}{l}\text { Main findings/ limitations } \\
\text { Conclusions/ } \\
\text { Recommendations }\end{array}$ \\
\hline $\begin{array}{l}\text { Maiduguri teaching hospital, Nigeria. Annals of } \\
\text { African Medicine, 8(2), 127-132. } \\
\text { http://doi.org/10.4103/1596-3519.56242 }\end{array}$ & & $\begin{array}{l}\text { January } 2000 \text { to } \\
\text { December } 2005 \\
10,097 \text { deliveries }\end{array}$ & & $\begin{array}{l}\text { - Eclampsia caused } 7.2 \% \text { and severe pregnancy- } \\
\text { induced hypertension caused } 4.8 \%\end{array}$ \\
\hline $\begin{array}{l}\text { Igwegbe, A., \& Udigwe, G. (2001). Teenage } \\
\text { pregnancy: still an obstetric risk. Journal of } \\
\text { Obstetrics and Gynaecology, 21(5), 478-481. }\end{array}$ & $\begin{array}{l}\text { Retrospective } \\
\text { and } \\
\text { comparative } \\
\text { study }\end{array}$ & $\begin{array}{l}\text { Nnamdi Azikiwe } \\
\text { University Teaching } \\
\text { Hospital, Nnewi. } \\
\text { June } 1 \text { 1995- } \\
\text { November 31, } 1997 \\
1465 \text { deliveries }\end{array}$ & $\begin{array}{l}\text { Reviewed hospital records of } 28 \\
\text { teenage deliveries and } 30 \text { records } \\
\text { of mothers aged } 20-24 \text { were } \\
\text { randomly selected to be used as } \\
\text { controls }\end{array}$ & $\begin{array}{l}\text { - } 32 \text { teenage deliveries, } 21.8 \text { per } 1000 \text { deliveries } \\
\text { This study found no significant difference between } \\
\text { the teenagers and the control group with regard to } \\
\text { PE/E }\end{array}$ \\
\hline $\begin{array}{l}\text { Makinde, O. N., Adegoke, O. A., Adediran, I. A., } \\
\text { Ndububa, D. A., Adeyemi, A. B., Owolabi, A. T., } \\
\text {... Salawu, L. (2009). HELLP syndrome: the } \\
\text { experience at lle-lfe, Nigeria. Journal of } \\
\text { Obstetrics and Gynaecology: The Journal of the } \\
\text { Institute of Obstetrics and Gynaecology, 29(3), } \\
\text { 195-199. } \\
\text { http://doi.org/10.1080/0144361090275394 } \\
5\end{array}$ & (cohort) & $\begin{array}{l}\text { Obafemi Awolowo } \\
\text { University Teaching } \\
\text { Hospitals Complex, } \\
\text { lle-Ife, Nigeria } \\
\text { January 1-December } \\
31,2006 \\
34 \text { consecutive cases } \\
\text { of severe PE/E }\end{array}$ & $\begin{array}{l}\text { Cases of severe PE/E were } \\
\text { recruited and bloodwork and other } \\
\text { biochecmical studies done (platelet } \\
\text { count, peripheral blood smear, } \\
\text { serum bilirubin lactate } \\
\text { dehydrogenase, and aspartate } \\
\text { transaminases estimation) } \\
\text { HELLP syndrome was diagnosed in } \\
\text { those who developed: haemolysis, } \\
\text { abnormal liver function and } \\
\text { thrombocytopenia (platelet count } \\
\leq 90,000 \mathrm{~mm}^{3} \text { ) were }\end{array}$ & $\begin{array}{l}\text { Each patient was categorized into three categories: } \\
\text { 1) } 12 \text { cases Severe PE: hypertension after } 20^{\text {th }} \text { week, } \\
\text { dBP } \geq 110 \mathrm{mmHg} \text { on admission, proteinuria } \\
\geq 30 \mathrm{mg} / \mathrm{dl} \text { in random urine specimen or } \geq 300 \mathrm{mg} \\
\text { in } 24 \mathrm{hr} \\
\text { 2) } 10 \text { cases Imminent eclampsia: all parameters in } \\
\text { (1) plus headache, blurring of vision and upper } \\
\text { abdominal pain } \\
12 \text { cases Eclampsia: all parameters in (1) and } \\
\text { seizures. } \\
\text { Six (17.6\%) of the cases developed HELLP } \\
\text { syndrome. } 4 \text { had eclampsia, } 1 \text { had imminent } \\
\text { eclampsia and } 1 \text { had pre-eclampsia } \\
\text { CFR: } 11.8 \% \text { The only fatalities were the four } \\
\text { eclamptic patients who also had HELLP syndrome. } \\
\text { There were } 38 \text { infants delivered, and six (15.8\%) } \\
\text { perinatal deaths. }\end{array}$ \\
\hline $\begin{array}{l}\text { Ndukwe, K., Ugboko, V., Ogunlola, I., Orji, E., \& } \\
\text { Makinde, O. (2004). Orofacial injuries in } \\
\text { eclamptic Nigerians. African Journal of } \\
\text { Reproductive Health, 8(3), 147-151. }\end{array}$ & $\begin{array}{l}\text { Retrospective } \\
\text { case review }\end{array}$ & $\begin{array}{l}\text { Department of } \\
\text { Obstetrics and } \\
\text { Gynaecology Obafemi } \\
\text { Awolowo University } \\
\text { Teaching Hospital, } \\
\text { Ile-Ife, Nigeria } \\
\text { January } 1994 \text { to July } \\
2002 \\
173 \text { patient records }\end{array}$ & $\begin{array}{l}\text { Cases from patients with eclampsia } \\
\text { during the study period were } \\
\text { identified, and data extracted and } \\
\text { analyzed. }\end{array}$ & $\begin{array}{l}\text { - } 21 \text { of the } 173 \text { cases (12.1\%) sustained orofacial } \\
\text { injuries (mostly lacerations and bruises to soft } \\
\text { tissues including the tongue). Dislocation of the } \\
\text { lower jaw (temporomandibular joint dislocation) } \\
\text { occurred in one case. Two patients died due to } \\
\text { complications related to uncontrolled bleeding, } \\
\text { acute renal failure and septicemia. } \\
\text { "antibiotics were prescribed in all the cases as part } \\
\text { of the treatment regimen for eclampsia" } \\
\text { Recommend a campaign to ensure ANC } \\
\text { attendance and against the forceful insertion of } \\
\text { unpadded objects into the mouth during seizure. }\end{array}$ \\
\hline
\end{tabular}




\begin{tabular}{|c|c|c|c|c|}
\hline Citation & Study Design & $\begin{array}{l}\text { Location, Timeframe, } \\
\text { and Sample size }\end{array}$ & Brief summary of Methods & $\begin{array}{l}\text { Main findings/ limitations } \\
\text { Conclusions/ } \\
\text { Recommendations }\end{array}$ \\
\hline $\begin{array}{l}\text { Okafor, U., \& Efetie, E. (2006). Cerebrovascular } \\
\text { accident with quadriplegia following } \\
\text { postpartum eclampsia. ACTA } \\
\text { ANAESTHESIOLOGICA SCANDINAVICA }\end{array}$ & Case report & $\begin{array}{l}\text { National Hospital, } \\
\text { Abuja } \\
\text { One, } 26 \text {-year-old } \\
\text { woman }\end{array}$ & $\begin{array}{l}\text { The patient diagnosed with } \\
\text { postpartum eclampsia was referred } \\
\text { from a peripheral hospital, she } \\
\text { delivered a live baby vaginally and } \\
\text { experienced a tonic/clonic seizure } \\
\text { just after delivering and became } \\
\text { unconscious. } \\
\text { After seizing, her Glasgow Coma } \\
\text { score was determined to be } 3 \text {, } \\
\text { meaning she was deeply } \\
\text { unconscious. } \\
\text { She had a fever }\left(38^{\circ} \mathrm{C}\right) \text {, mild pedal } \\
\text { oedema, puffy eyes and "grunting } \\
\text { respiration," a BP of } 130 / 80 \\
\text { mmHg on presentation. }\end{array}$ & $\begin{array}{l}\text { - There had been no history of elevated BP during } \\
\text { ANC. } \\
\text { Her case was managed with magnesium sulphate, } \\
\text { IV } 5 \% \text { dextrose/salinje, 50\% dextrose and Zinacef } \\
\text { (antibiotic). } \\
\text { - She remained in the ICU for } 42 \text { days and was } \\
\text { discharged from the Hospital after } 169 \text { days. BP } \\
\text { had normalized, but she was still quadriplegic. } \\
\text { This is the only known case of quadriplegia } \\
\text { resulting from postpartum eclampsia in sub- } \\
\text { Saharan Africa. } \\
\text { This study reinforced the thought that neurological } \\
\text { effects of PE/E are more common when eclampsia } \\
\text { presents postpartum; this patient had cerebral } \\
\text { oedema }\end{array}$ \\
\hline $\begin{array}{l}\text { Okafor, U., \& Efetie, E. (2009). Anaesthetic } \\
\text { management of patients with pre- } \\
\text { eclampsia/eclampsia and perinatal outcome. } \\
\text { Journal of Maternal- Fetal and Neonatal } \\
\text { Medicine, 22(8), 688-692. }\end{array}$ & $\begin{array}{l}\text { Retrospective } \\
\text { record review }\end{array}$ & $\begin{array}{l}\text { University of Nigeria } \\
\text { Teaching Hospital } \\
\text { (UNTH), Enugu. } \\
\text { July } 1998 \text {-June } \\
2008 \\
6798 \text { total deliveries, } \\
285 \text { cases PE/E, } \\
196 \text { cases of PE/E } \\
\text { delivered by CS }\end{array}$ & $\begin{array}{l}\text { Hospital records for patients with } \\
\mathrm{PE} / \mathrm{E} \text { who had caesarean delivery } \\
\text { were reviewed and demographics, } \\
\text { obstetric outcomes, and type of } \\
\text { anaesthesia administered was } \\
\text { recorded and analyzed. }\end{array}$ & $\begin{array}{l}\text { 12.4\% (n=196) of all CS were for patients with } \\
\text { PE/E. (59: mild PE, 107: severe PE, 30: eclampsia) } \\
\text { - This group experienced } 38 \text { perinatal deaths, } 180 \\
\text { per } 1000 \text { births (19 stillbirths and } 19 \text { early } \\
\text { neonatal deaths). } \\
\text { - } 157 \text { were delivered under general anaesthesia; } 34 \\
\text { under spinal anaesthesia and } 5 \text { under epidural } \\
\text { block. } \\
\text { 79\% of the perinatal deaths were delivered by } \\
\text { general anaesthesia. } \\
\text { Indications for CS among PE/E patients included: } \\
\text { severe PE/E with unfavorable cervix, fetal } \\
\text { distress/intrauterine growth retardation, previous } \\
\text { CS, failed induction/failed vacuum extraction, } \\
\text { prolonged labor and others } \\
25.6 \% \text { of perinatal deaths occurred in cases of } \\
\text { severe PE, } 21.2 \% \text { occurred in cases of eclampsia } \\
\text { and only } 4.9 \% \text { occurred in cases of PE. } \\
\text { 89\% of neonatal deaths occurred <36 weeks; } 52 \% \\
\text { were <32 weeks } \\
\text { The increase to } 20 \% \text { use of regional anaesthesia } \\
\text { (vs } 1.3 \% \text { in an earlier study) did not seem to have } \\
\text { an impact on perinatal death. } \\
\end{array}$ \\
\hline
\end{tabular}




\begin{tabular}{|c|c|c|c|c|}
\hline Citation & Study Design & $\begin{array}{l}\text { Location, Timeframe, } \\
\text { and Sample size }\end{array}$ & Brief summary of Methods & $\begin{array}{l}\text { Main findings/ limitations } \\
\text { Conclusions/ } \\
\text { Recommendations }\end{array}$ \\
\hline $\begin{array}{l}\text { Okafor, U., \& Okezie, O. (2005). Maternal and } \\
\text { fetal outcome of anaesthesia of caesarean } \\
\text { delivery in preeclampsia / eclampsia in Enugu, } \\
\text { Nigeria: a retrospective observational study. } \\
\text { International Journal of Obstetric Anesthesia, } \\
\text { 14(2), 108-113. }\end{array}$ & $\begin{array}{l}\text { Retrospective } \\
\text { survey of } \\
\text { hospital } \\
\text { records }\end{array}$ & $\begin{array}{l}\text { University of Nigeria } \\
\text { Teaching Hospital } \\
\text { (UNTH), Enugu. } \\
\text { July } 1998 \text {-June } \\
2002 \\
3926 \text { total deliveries, } \\
898 \text { CS deliveries } \\
125 \text { cases of PE/E } \\
\text { delivered by CS }\end{array}$ & $\begin{array}{l}176 \text { of } 3926(4.5 \%) \text { deliveries were } \\
\text { complicated by PE/E } \\
\text { CFR: } 5.2 \%\end{array}$ & 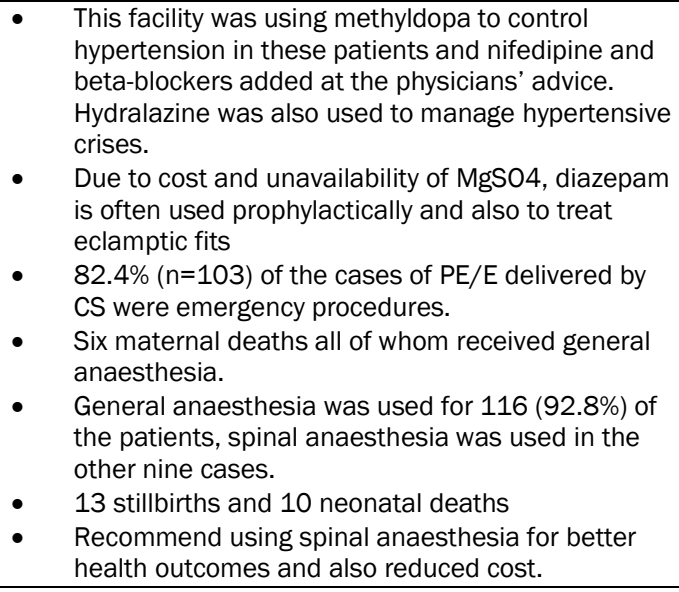 \\
\hline $\begin{array}{l}\text { Oladapo, OT, JO Sotunsa, and AO Sule-Odu. } \\
\text { "The Rise in Caesarean Birth Rate in Sagamu, } \\
\text { Nigeria: Reflection of Changes in Obstetric } \\
\text { Practice." Journal of Obstetrics and } \\
\text { Gynaecology } 24.4 \text { (2004): 377-381. }\end{array}$ & $\begin{array}{l}\text { Retrospective } \\
\text { comparative } \\
\text { study }\end{array}$ & $\begin{array}{l}\text { Olabisi Onabanjo } \\
\text { University Teaching } \\
\text { Hospital, Sagamu } \\
\text { Two periods: } \\
\text { January 1, 1989_- } \\
\text { December 31, 1991 } \\
\text { July 1, 2000-June } \\
\text { 30, } 2003\end{array}$ & $\begin{array}{l}\text { Data were collected from theatre } \\
\text { records, labor ward records, and } \\
\text { case files on deliveries during the } \\
\text { two study periods. }\end{array}$ & $\begin{array}{l}\text { - This study found that hypertensive disorders in } \\
\text { pregnancy (severe PE/E) was cited as the } \\
\text { indication for CS in } 20 \text { (8.9\%) of caesareans during } \\
\text { from 1989-1991 } \\
\text { This increased to } 13.4 \%(n=44) \text { of CS due to } \\
\text { severe PE/E in } 2000-2003 \text {. } \\
\text { This finding is in line with other papers that report } \\
\text { better maternal and fetal outcomes when a woman } \\
\text { with severe PE/E is delivered via caesarean. }\end{array}$ \\
\hline $\begin{array}{l}\text { OLADAPO, O. T., ADEKANLE, D. A., \& } \\
\text { DUROJAIYE, B. O. (2007). Maternal risk factors } \\
\text { associated with fetal death during antenatal } \\
\text { care in low-resource tertiary hospitals. } \\
\text { Australian and New Zealand Journal of } \\
\text { Obstetrics and Gynaecology, 47(5), 383-388. }\end{array}$ & $\begin{array}{l}\text { Case control } \\
\text { study }\end{array}$ & $\begin{array}{l}\text { Olabisi Onabanjo } \\
\text { University Teaching } \\
\text { Hospital, Sagamu, } \\
\text { Ogun State (OOUTH) } \\
\text { and Ladoke Akintola } \\
\text { University of } \\
\text { Technology Teaching } \\
\text { Hospital, Osogbo, } \\
\text { Osun state } \\
\text { (LAUTECHTH) } \\
\text { January 1, 2002 and } \\
\text { December 31, } 2006 \\
\text { at OOUTH }\end{array}$ & $\begin{array}{l}\text { Cases: booked singleton } \\
\text { pregnancies who experienced fetal } \\
\text { death during ANC } \\
\text { Controls: booked pregnancies who } \\
\text { had live births } \\
\text { Four controls selected for each } \\
\text { case (two immediately before and } \\
\text { two after each case). } \\
\text { Cases and controls were } \\
\text { compared. }\end{array}$ & $\begin{array}{l}\text { - } \quad \text { After multivariate logistic regression analyses, the } \\
\text { following were found as predictors for fetal death } \\
\text { among women receiving ANC: pregnancy induced } \\
\text { hypertension (adjusted OR: } 8.24, \mathrm{Cl} 3.01-22.51 \text { ), } \\
\text { proteinuria (adj. OR 4.23, Cl: } 1.57-11.42 \text { ) and } \\
\text { perceived reduction of fetal movements (adj OR } \\
\text { 7.17, Cl: } 1.57-45.76 \text { ). } \\
\text { - } \% \text { of cases and controls with: } \\
\text { - } \quad \text { proteinuria: Cases: } 41.9 \% \text {, controls, } 11.0 \% \\
\text { - PIH: cases: } 43.5 \% \text {, controls: } 7.6 \% \\
\text { - } \quad \text { previous hypertension: cases: } 10.9 \% \text {, controls: } \\
\text { - } \quad \text { PE: cases } 24.4 \% \text {, controls: } 0.0 \%\end{array}$ \\
\hline
\end{tabular}




\begin{tabular}{|c|c|c|c|c|}
\hline Citation & Study Design & $\begin{array}{l}\text { Location, Timeframe, } \\
\text { and Sample size }\end{array}$ & Brief summary of Methods & $\begin{array}{l}\text { Main findings/ limitations } \\
\text { Conclusions/ } \\
\text { Recommendations }\end{array}$ \\
\hline & & $\begin{array}{l}\text { January 1, 2003- } \\
\text { December 31, } 2006 \\
\text { LAUTECHTH } \\
\text { Cases: } 46 \\
\text { Controls: } 184\end{array}$ & & \\
\hline $\begin{array}{l}\text { Olagbuji, B., Ezeanochie, M., Ande, A., \& } \\
\text { Okonkwo, C. (2012). Prevalence and } \\
\text { risk factors for persistent hypertension } \\
\text { after the puerperium in pregnancies } \\
\text { complicated with hypertensive } \\
\text { disorders. Journal of Obstetrics and } \\
\text { Gynaecology: The Journal of the } \\
\text { Institute of Obstetrics and Gynaecology, } \\
\text { 32(6), 529-532. }\end{array}$ & $\begin{array}{l}\text { Prospective } \\
\text { cohort study }\end{array}$ & $\begin{array}{l}\text { University of Benin } \\
\text { Teaching Hospital } \\
\text { (UBTH), Benin City, } \\
\text { Nigeria } \\
\text { December 2009- } \\
\text { November } 2010 . \\
198 \text { women }\end{array}$ & $\begin{array}{l}\text { Women who were managed for } \\
\text { new-onset gestational hypertensive } \\
\text { disorders who had received ANC, } \\
\text { intrapartum and postpartum care } \\
\text { at the facility were recruited during } \\
\text { the prenatal period. } \\
\text { "new-onset gestational } \\
\text { hypertensive disorders" = } \\
\text { gestational hypertension, or PE/E } \\
\text { after } 20 \text { weeks gestation in } \\
\text { previously normotensive, non- } \\
\text { proteinuric women with no history } \\
\text { of chronic hypertension. }\end{array}$ & $\begin{array}{l}\text { - } \quad \text { "Persistent hypertension" was diagnosed if } \\
\text { hypertension remained during the postpartum visit, } \\
\text { six weeks after delivery. } \\
51(25.8 \%) \text { were discovered to have persistent } \\
\text { hypertension at the 6th week postnatal follow up } \\
\text { visit. } \\
\text { - Persistent hypertension was significantly higher } \\
\text { among women with maternal age }>35 \text { years old } \\
\text { and also among HIV-positive women. } \\
\text { - Serum uric acid and creatinine levels were also } \\
\text { significantly higher among the women who } \\
\text { developed persistent hypertension }\end{array}$ \\
\hline $\begin{array}{l}\text { Olusanya, B. O., \& Solanke, O. A. (2012). } \\
\text { Perinatal outcomes associated with maternal } \\
\text { hypertensive disorders of pregnancy in a } \\
\text { developing country. Hypertension in Pregnancy, } \\
\text { 31(1), 120-130. }\end{array}$ & $\begin{array}{l}\text { Retrospective } \\
\text { study }\end{array}$ & $\begin{array}{l}\text { Island Maternity } \\
\text { Hospital (IMH), Lagos } \\
\text { May 15, 2005-2007 } \\
216 \text { mothers with } \\
\text { HDP }\end{array}$ & $\begin{array}{l}\text { Mothers with HDP were recruited } \\
\text { and their cases reviewed for: fetal } \\
\text { distress, prematurity ( }<37 \text { weeks } \\
\text { gestation), low birth weight } \\
\text { (<2500g), fetal growth restriction, } \\
\text { birth asphyxia, admission to special } \\
\text { baby care unit, and lack of } \\
\text { exclusive breastfeeding as well as } \\
\text { maternal factors. } \\
\text { Hypertensive disorders of } \\
\text { pregnancy (HDP): chronic } \\
\text { hypertension, pregnancy-induced } \\
\text { hypertension, pre-eclampsia and } \\
\text { eclampsia }\end{array}$ & $\begin{array}{l}\text { - } 216 \mathrm{HDP} / 3491 \text { mother-infant pairs = 6.2\% } \\
\text { incidence of HDP } \\
10(4.6 \%) \text { were chronic hypertension, } 120(55.6 \%) \text { : } \\
\text { - } \quad \text { regnancy-induced hypertension, } 86 \text { (39.8\%): PE/E } \\
\text { After adjusting for maternal factors and some } \\
\text { relevant infant confounders, this study saw that } \\
\text { HDP increased the odds of preterm birth (OR 3.30), } \\
\text { fetal growth restriction (OR 2.94), low birth weight } \\
\text { (OR 4.68) and birth asphyxia (OR 2.99). } \\
\text { Recommends greater collaboration between } \\
\text { obstetricians and pediatricians to address HDP and } \\
\text { its effects beyond maternal and perinatal mortality. }\end{array}$ \\
\hline
\end{tabular}




\begin{tabular}{|c|c|c|c|c|}
\hline Citation & Study Design & $\begin{array}{l}\text { Location, Timeframe, } \\
\text { and Sample size }\end{array}$ & Brief summary of Methods & $\begin{array}{l}\text { Main findings/ limitations } \\
\text { Conclusions/ } \\
\text { Recommendations }\end{array}$ \\
\hline $\begin{array}{l}\text { Olusanya, B. O., \& Solanke, O. A. (2012). } \\
\text { Maternal and neonatal profile of late-preterm } \\
\text { survivors in a poorly resourced country. The } \\
\text { Journal of Maternal-Fetal \& Neonatal Medicine, } \\
25(4), 346-352 .\end{array}$ & $\begin{array}{l}\text { Cross- } \\
\text { sectional } \\
\text { study }\end{array}$ & $\begin{array}{l}\text { Island Maternity } \\
\text { Hospital, Lagos } \\
\text { May 2005- } \\
\text { December } 2007 \\
4176 \text { Surviving late } \\
\text { preterm and full-term } \\
\text { live births }\end{array}$ & $\begin{array}{l}\text { Infants were recruited under } 24 \\
\text { hours after birth, before being } \\
\text { discharged from the hospital. } \\
\text { Late preterm was defined as: } 34^{0 / 7} \\
\text { to } 36^{6 / 7} \text { weeks gestation. } \\
\text { Gestational age was based on } \\
\text { number of days between LMP (last } \\
\text { menstrual period) and delivery }\end{array}$ & $\begin{array}{l}\text { - } 89 \text { (38.4\% of women with hypertensive disorders: } \\
\mathrm{PE} / \mathrm{E} \text { and } \mathrm{PIH} \text { ) had PE/E and } 41 \text { (46.1\%) of them } \\
\text { were late-preterm } \\
\text { - Univariate analysis showed that having a } \\
\text { hypertensive disorder was significantly associated } \\
\text { with late-preterm delivery } \\
\text { - Multivariate analysis revealed that late-preterm } \\
\text { delivery was independently associated with } \\
\text { hypertensive disorders (OR 3.66, Cl 1.97-6.84). }\end{array}$ \\
\hline $\begin{array}{l}\text { Onuh, S., \& Aisien, A. (2004). Maternal and } \\
\text { fetal outcome in eclamptic patients in Benin } \\
\text { City, Nigeria. Journal of Obstetrics and } \\
\text { Gynaecology, 24(7), 765-768. }\end{array}$ & & $\begin{array}{l}\text { University of Benin } \\
\text { Teaching Hospital } \\
\text { 1995-2002 } \\
103 \text { cases of } \\
\text { eclampsia }\end{array}$ & $\begin{array}{l}\text { Patient data for cases of eclampsia } \\
\text { was retrieved from case notes and } \\
\text { summary sheets and analyzed. }\end{array}$ & 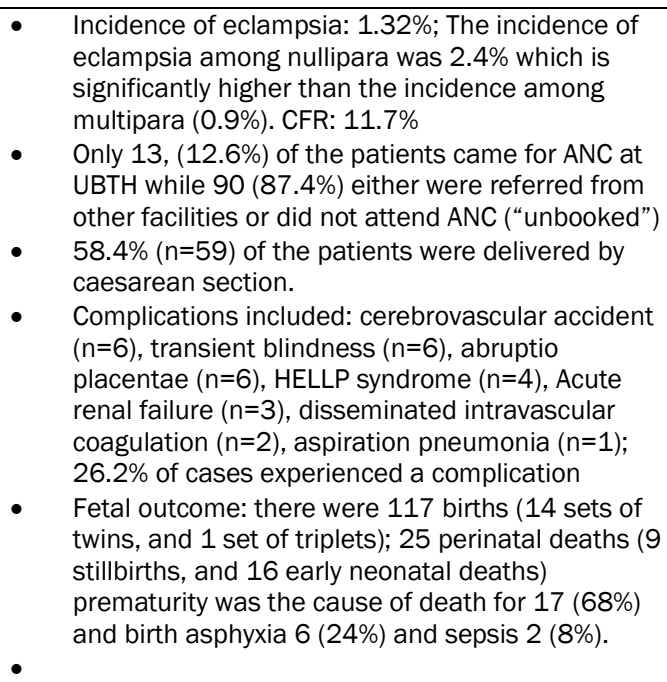 \\
\hline $\begin{array}{l}\text { Onyearugha, C. N., \& Ugboma, H. A. A. (2012). } \\
\text { Fetal outcome of antepartum and intrapartum } \\
\text { eclampsia in Aba, southeastern Nigeria. } \\
\text { Tropical Doctor, 42(3), 129-132. }\end{array}$ & $\begin{array}{l}\text { Retrospective } \\
\text { review of } \\
\text { hospital } \\
\text { registers }\end{array}$ & $\begin{array}{l}\text { Department of } \\
\text { Obstetrics and } \\
\text { Gynaecology, Abia } \\
\text { State University } \\
\text { Teaching Hospital, } \\
\text { Abia } \\
\text { January 1, 2002- } \\
\text { December 31, 2007 } \\
48 \text { babies delivered } \\
\text { to eclamptic mothers }\end{array}$ & $\begin{array}{l}\text { Relevant information (gestational } \\
\text { age, birthweight five-minute Apgar } \\
\text { score and mother's age, booking } \\
\text { status parity, number of fits and } \\
\text { mode of delivery) was obtained } \\
\text { from delivery registers for } 48 \\
\text { babies delivered to eclamptic } \\
\text { mothers; data analyzed. }\end{array}$ & $\begin{array}{l}\text { - Hospital incidence of eclampsia- 0.80\%; CFR: } \\
20.8 \% \\
\text { Women only come to this facility for treatment as a } \\
\text { last resort; tradition treatment for fitting is "crude } \\
\text { oil pushed into their mouths and eyes" } \\
13 \text { babies were <1500g, } 15 \text { were } 1500 \mathrm{~g}-2499 \mathrm{~g}, \\
19 \text { were } 2500 \mathrm{~g}-4000 \mathrm{~g} \text {, and } 1 \text { was }>4000 \mathrm{~g} \\
\text { - Five-minute Apgar sore: } 29(60 \%)=0 \text { [stillborn], } 4 \\
(8.3 \%)=1-3 \text { [severely asphyxiated], } 9(18.8 \%)=4- \\
6,6(12.5 \%)>7 \\
\text { Poor Apgar scores could be partly explained by } \\
\text { asphyxiogenic effect in utero during maternal } \\
\text { convulsions. }\end{array}$ \\
\hline
\end{tabular}




\begin{tabular}{|c|c|c|c|c|}
\hline Citation & Study Design & $\begin{array}{l}\text { Location, Timeframe, } \\
\text { and Sample size }\end{array}$ & Brief summary of Methods & $\begin{array}{l}\text { Main findings/ limitations } \\
\text { Conclusions/ } \\
\text { Recommendations }\end{array}$ \\
\hline & & & & \\
\hline $\begin{array}{l}\text { Onyiriuka, A. N., \& Okolo, A. A. (2007). Neonatal } \\
\text { morbidity pattern in infants born in Benin City } \\
\text { to Nigerian mothers with hypertensive } \\
\text { disorders in pregnancy. Nigerian Journal of } \\
\text { Clinical Practice, 10(4), 294-299. }\end{array}$ & $\begin{array}{l}\text { Case control } \\
\text { study }\end{array}$ & $\begin{array}{l}\text { University of Benin } \\
\text { Teaching Hospital } \\
\text { (UBTH) } \\
\text { January 1, 1992- } \\
\text { June 30, } 1994 \\
\text { Cases: } 256 \text { live } \\
\text { newborns of } \\
\text { hypertensive mothers } \\
\text { Controls: } 804 \text { infants } \\
\text { of normotensive } \\
\text { mothers }\end{array}$ & $\begin{array}{l}\text { For each hypertensive mother } \\
\text { recruited, three normotensive } \\
\text { pregnant mothers were recruited } \\
\text { as controls. All participants came } \\
\text { for clinical visits every } 2 \text { weeks and } \\
\text { had BP measured and urine tested } \\
\text { HDP= documented history of } \\
\text { hypertension (140/90 mmHg) } \\
\text { before pregnancy, an increase in } \\
\text { either SBP (by } 30 \mathrm{mmHg} \text { ) or DBP (by } \\
15 \mathrm{mmHg} \text { ) above the booking BP, } \\
\text { an intrapartum blood pressure = } \\
140.90 \text { mmHg obtained on at least } \\
\text { two occasions not less than six } \\
\text { hours apart during delivery }\end{array}$ & $\begin{array}{l}\text { - Comparing the outcomes of the infants born to } \\
\text { hypertensive vs. normotensive women, this study } \\
\text { found that } 39.5 \% \text { vs } 17.9 \% \text { were low birth weight, } \\
29.3 \% \text { vs. } 12 . \% \text { were preterm } \\
\text { Caesarean delivery rate was significantly higher } \\
\text { among hypertensive women. } \\
\text { - This study concludes that "pregnancies } \\
\text { complicated by hypertension are associated with } \\
\text { an increase in neonatal morbidity" and that these } \\
\text { infants are a high-risk group that need close } \\
\text { attention and treatment of these specific } \\
\text { outcomes. }\end{array}$ \\
\hline $\begin{array}{l}\text { Osinubi, A., Ajayi, G., \& Adegbola, O. (2009). } \\
\text { Effect of normal and pre-eclamptic pregnancies } \\
\text { on plasma cholinesterase in Nigerian women. } \\
\text { African Journal of Endocrinology and } \\
\text { Metabolism, 8(1), 1-3. }\end{array}$ & $\begin{array}{l}\text { Case control } \\
\text { study }\end{array}$ & $\begin{array}{l}\text { Antenatal Clinic and } \\
\text { Prenatal Diagnostic } \\
\text { and Therapy Center, } \\
\text { College of Medicine } \\
\text { of the University of } \\
\text { Lagos/Lagos } \\
\text { University Teaching } \\
\text { Hospital } \\
30 \text { women: mild PE } \\
27 \text { women: severe PE } \\
30 \text { : normal } \\
\text { pregnancy } \\
30 \text { healthy non- } \\
\text { pregnant women }\end{array}$ & $\begin{array}{l}\text { Patients were recruited and } \\
\text { categorized into four groups: } \\
\text { healthy non pregnant, healthy } \\
\text { pregnant, mild PE and severe PE } \\
\text { Mild PE: pregnancy-induced sBP } \\
>160 \mathrm{mmHg} \text { or diastolic } \mathrm{BP} \geq \\
\text { 110mmHg with proteinuria } 2+ \\
\text { Severe PE: any two of the following } \\
\text { signs were present: }(1) \text { systolic } \\
\text { blood pressure }>160 \mathrm{mmHg} \text { or } \\
\text { diastolic blood pressure }>110 \\
\text { mmHg; }(2) \text { proteinuria }(>3+\text { on } \\
\text { dipstick [ } 500 \mathrm{mg} / \mathrm{dL}]) ;(3) \text { facial } \\
\text { oedema. }\end{array}$ & $\begin{array}{l}\text { Plasma cholinesterase concentrations: } \\
\text { Healthy, non-pregnant (controls) } 3594 \pm 422 \mathrm{~m} / \mathrm{L} \\
\text { Healthy pregnant: } 2135 \pm 330 \text { [postpartum: } 3212 \\
\pm 346 \text {. Mild PE: } 1781 \pm 330 \text { [postpartum: } 3157 \pm \\
75 \text { ] } \\
\text { Severe PE: } 1630 \pm 326 \text { [postpartum: } 2864 \pm 700 \text { ] } \\
\text { This study found that pregnancy reduced plasma } \\
\text { cholinesterase concentrations when compared to } \\
\text { healthy non-pregnant women; PE further reduced } \\
\text { concentrations when compared to normal pregnant } \\
\text { women. } \\
\text { Reduced plasma cholinesterase activity leads to } \\
\text { prolonged succinylcholine effect. } \\
\text { It was also noted, that cases of severe PE did not } \\
\text { see concentrations of serum cholinesterase return } \\
\text { to normal within six weeks after delivery. } \\
\text { Recommendations: cases of severe PE should be } \\
\text { monitored beyond six weeks postpartum, consider } \\
\text { using peripheral nerve stimulator when }\end{array}$ \\
\hline
\end{tabular}




\begin{tabular}{|c|c|c|c|c|}
\hline Citation & Study Design & $\begin{array}{l}\text { Location, Timeframe, } \\
\text { and Sample size }\end{array}$ & Brief summary of Methods & $\begin{array}{l}\text { Main findings/ limitations } \\
\text { Conclusions/ } \\
\text { Recommendations }\end{array}$ \\
\hline & & & $\begin{array}{l}\text { Serum cholinesterase } \\
\text { concentrations were measured by } \\
\text { collecting blood and separating the } \\
\text { plasma for cholinesterase assays } \\
\text { between } 28-41 \text { weeks for } \\
\text { pregnant women and } 6 \text { weeks } \\
\text { postpartum }\end{array}$ & $\begin{array}{l}\text { succinylcholine is administered in } \mathrm{PE} / \mathrm{E} \text {, further } \\
\text { research targeting cholinesterase activity as } \\
\text { diagnostic tool and prognostic marker in } \mathrm{PE} / \mathrm{E} \\
\text { pregnancies. }\end{array}$ \\
\hline $\begin{array}{l}\text { Ozumba, B. C., \& Anya, S. E. (2002). Maternal } \\
\text { deaths associated with cesarean section in } \\
\text { Enugu, Nigeria. International Journal of } \\
\text { Gynaecology and Obstetrics: The Official Organ } \\
\text { of the International Federation of Gynaecology } \\
\text { and Obstetrics, 76(3), 307-309. }\end{array}$ & & $\begin{array}{l}\text { University of Nigeria } \\
\text { Teaching Hospital, } \\
\text { Enugu } \\
\text { January 1994- } \\
\text { December } 1999 \\
\text { 1,684 cesarean } \\
\text { section deliveries }\end{array}$ & & $\begin{array}{l}\text { - } \quad \text { Overall CS rate of } 25.6 \% \\
\text { Hypertensive disorders of pregnancy (HDP) was } \\
\text { cited as indication for } 27 \% \text { of CS (behind } \\
\text { prolonged/ obstructed labor, } 31 \% \text { ). } \\
\text { There were } 26 \text { deaths following CS, } 23 \% \text { of which } \\
\text { were associated with HDP }\end{array}$ \\
\hline $\begin{array}{l}\text { Waziri-Erameh, M. J., Omoti, a E., \& Edema, O. } \\
\text { T. (2003). Bilateral total loss of vision following } \\
\text { eclampsia--a case report. African Journal of } \\
\text { Reproductive Health, } 7(2), 106-108 .\end{array}$ & Case report & Benin City & $\begin{array}{l}31 \text { year old patient, para- } 5 \text { who } \\
\text { suffered bi-lateral total loss of } \\
\text { vision for four weeks. She had been } \\
\text { successfully treated for eclampsia } \\
\text { and lost vision during the } \\
\text { convulsion, this progressively } \\
\text { became worse and she was } \\
\text { referred for ophthalmological } \\
\text { consultation }\end{array}$ & $\begin{array}{l}\text { - Eclampsia was treated using Hydrallazine to } \\
\text { reduce the blood pressure and diazepam to stop } \\
\text { the convulsions. } \\
\text { Upon referral, she had a blood pressure of } 130.90 \text {, } \\
\text { which may indicate that she had underlying } \\
\text { hypertension during pregnancy } \\
\text { Steroids were given and within a few weeks, her } \\
\text { vision was restored. }\end{array}$ \\
\hline
\end{tabular}




\section{Appendix V:}

\section{SUMMARY TABLES OF PROGRAM DESCRIPTIONS AND LITERATURE REVIEWS}

\begin{tabular}{|c|c|c|}
\hline Citation & Paper Type & Summary \\
\hline $\begin{array}{l}\text { Abalos, E., Cuesta, C., Grosso, A., Chou, D., \& } \\
\text { Say, L. (2013). Global and regional estimates of } \\
\text { preeclampsia and eclampsia: a systematic } \\
\text { review. European Journal of Obstetrics \& } \\
\text { Gynecology and Reproductive Biology, 170(1), } \\
\text { 1-7. }\end{array}$ & Systematic Review & $\begin{array}{l}11 \text { datasets found on } \mathrm{PE} / \mathrm{E} \text { in Nigeria ( } 4 \text { on } \mathrm{PE}, 7 \text { on } \mathrm{E} \text { ). Total population covered by these datasets }=54,144 \\
\text { women. Crude incidence of PE among the four datasets }=4.6 \% \text { and crude incidence of } \mathrm{E} \text { among the } 7 \text { datasets } \\
=4.0 \%\end{array}$ \\
\hline $\begin{array}{l}\text { Ameh, C., \& van den Broek, N. (2015). Making It } \\
\text { Happen: Training health-care providers in } \\
\text { emergency obstetric and newborn care. Best } \\
\text { Practice \& Research Clinical Obstetrics \& } \\
\text { Gynaecology, 1-15. }\end{array}$ & Program description & $\begin{array}{l}\text { The Making It Happen multi-country programme (implemented in Nigeria during Phase II) aims to build the } \\
\text { capacity of health-care providers to recognize and manage complications during pregnancy, childbirth and the } \\
\text { post-partum period through 'skills-and-drills' competency-based training in skilled birth attendance, emergency } \\
\text { obstetric care and early newborn care (EmONC). } \\
\text { Key interventions under MiH programme are: } \\
\text { 1) in-service training of healthcare providers working in maternity areas (including management of severe PE/E) } \\
\text { 2) quality improvement using audit methodology } \\
\text { 3) improved monitoring and evaluation. }\end{array}$ \\
\hline $\begin{array}{l}\text { Ekele, B. A. (2009). Use of magnesium sulfate to } \\
\text { manage pre-eclampsia and eclampsia in Nigeria: } \\
\text { overcoming the odds. Annals of African } \\
\text { Medicine, } 8(2), 73-75 \text {. }\end{array}$ & Editorial & $\begin{array}{l}\text { Even though } \mathrm{MgSO}_{4} \text { has been shown to be the safest and most effective method for managing convulsions in } \\
\text { pregnant women and to prevent recurrence, many providers and facilities have been unable to adjust to the new } \\
\text { standard and still stock and use diazepam to manage eclampsia. Other barriers to using } \mathrm{MgSO}_{4} \text { include: fear of } \\
\text { toxicity (which is detectable and treatable using calcium gluconate), no local manufacturer making availability } \\
\text { more difficult and more expensive, and the dosage itself. }\end{array}$ \\
\hline $\begin{array}{l}\text { Garba, J., \& Umar, S. (2013). etiology of } \\
\text { maternal mortality using verbal autopsy at } \\
\text { Sokoto, North-Western Nigeria. Etiologie de la } \\
\text { mortalité maternelle en utilisant l'autopsie } \\
\text { verbale à Sokoto, Nigeria du Nord-Ouest. African } \\
\text { Journal of Primary Health Care and Family } \\
\text { Medicine, 5(1), } 6 \mathrm{p}\end{array}$ & $\begin{array}{l}\text { Descriptive, cross- } \\
\text { sectional study }\end{array}$ & $\begin{array}{l}\text { Interviews using a verbal autopsy questionnaire with relatives of a women } 15-49 \text { years old who had died of } \\
\text { pregnancy-related condition in the preceding two years. Sixty-two maternal deaths were identified and } 58 \\
\text { questionnaires for the verbal autopsy were completed. } \\
\text { Eclampsia was the cause of death for } 18.97 \% \text { (second most common after Haemorrhage, } 48.28 \% \text { ) } \\
\text { Among primipara, eclampsia was the cause of death for } 29.2 \%\end{array}$ \\
\hline $\begin{array}{l}\text { Hlimi, T. (2015). Association of anemia, pre- } \\
\text { eclampsia and eclampsia with seasonality: A } \\
\text { realist systematic review. Health \& Place, 31(0), }\end{array}$ & Systematic review & $\begin{array}{l}\text { Hlimi conducted a systematic literature review of studies that look at the effect of weather/rainfall/seasonality } \\
\text { might have on the development of anemia and PE/E. This review included three studies from Nigeria, one was }\end{array}$ \\
\hline
\end{tabular}




\begin{tabular}{|c|c|c|}
\hline Citation & Paper Type & Summary \\
\hline $180-192$. & & $\begin{array}{l}\text { published in 1970, one in } 1981 \text { and one in 2009. The study from } 2009 \text { (Okafor et al.) is included in this current } \\
\text { literature review on PE/E in Nigeria. } \\
\text { Overall, Hlimi found that there are often observed seasonal patterns for anemia and PE/E and that PE/E might } \\
\text { follow similar seasonal variation to malaria, but more research is needed. }\end{array}$ \\
\hline $\begin{array}{l}\text { Lalonde, A., \& Grellier, R. (2012). FIGO saving } \\
\text { mothers and newborns initiative } 2006-2011 . \\
\text { International Journal of Gynecology \& Obstetrics. }\end{array}$ & $\begin{array}{l}\text { Summary of FIGO } \\
\text { funded projects } \\
\text { under Safe } \\
\text { Motherhood and } \\
\text { Newborn Health } \\
\text { (SMNH) Committee }\end{array}$ & $\begin{array}{l}\text { One of the projects described was implemented in Nigeria: Saving mothers and newborns in Edo, Amambra and } \\
\text { Kaduna States; this project aimed to improve data collection and use, through improved birth register records, } \\
\text { fatal outcome records and clinical audits. The project also trained providers on EmONC and strengthened } \\
\text { capacity of national professional societies (midwifery and obstetric) through development of protocols and } \\
\text { advocacy activities. Three achievements of the project were: supplying } \mathrm{MgSO}_{4} \text { to all state hospitals by the } \\
\text { Kaduna state government, reduced cost of } \mathrm{MgSO}_{4} \text { by manufacturers and four obstetric protocols were } \\
\text { introduced. }\end{array}$ \\
\hline $\begin{array}{l}\text { McDonald, S., Lutsiv, O., Dzaja, N., \& Duley, L. } \\
\text { (2012). A systematic review of maternal and } \\
\text { infant outcomes following magnesium sulfate for } \\
\text { pre-eclampsia/eclampsia in real-world use. } \\
\text { International Journal of Gynecology and } \\
\text { Obstetrics, 118, 90-96. }\end{array}$ & Systematic review & $\begin{array}{l}\text { A systematic review of studies conducted looking at the effectiveness of magnesium sulfate. The authors } \\
\text { searched MEDLINE and EMBASE for studies published from January } 7,1990 \text { to July } 20,2010 \text { and included } \\
\text { 'before-and-after' studies, cohort studies, and serial cross-sectional studies which reported outcomes of women } \\
\text { receiving } \mathrm{MgSO}_{4} \text { compared to a group of women who did not. Studies looking at a sample }<10 \text { were excluded. } \\
\text { Primary outcomes were: maternal death, infant death, eclampsia or recurrent seizure. Secondary outcomes } \\
\text { included: pulmonary edema, pneumonia, cardiac arrest, coagulopathy, renal failure, liver failure, cerebral } \\
\text { hemorrhage, respiratory depression or arrest, toxicity (calcium gluconate required to stop toxic effect of } \mathrm{MgSO}_{4} \text { ), } \\
\text { length of stay in ICUs. From } 754 \text { citations, } 156 \text { full text articles were reviewed and } 150 \text { were excluded for } \\
\text { sample size, study design or failure to report outcomes of interest. } \\
\text { The six studies included were all cohort studies, included } 536 \text { women with eclampsia treated with } \mathrm{MgSO}_{4} \text { and } \\
698 \text { who were treated with another anticonvulsant. } \\
\text { The results from the six studies included, seem to indicate that the improvements demonstrated in RCTs are } \\
\text { comparable to those observed in real-world use of } \mathrm{MgSO}_{4} \text { and result in reduction in recurrent seizures, morbidity } \\
\text { and mortality. }\end{array}$ \\
\hline $\begin{array}{l}\text { Mohammed, S., Ahonsi, B., Oginni, A., Tukur, J., } \\
\& \text { Adoyi, G. (2015). Obstetric knowledge of } \\
\text { nurse-educators in Nigeria: Levels, regional } \\
\text { differentials and their implications for maternal } \\
\text { health delivery. Health Education Journal. }\end{array}$ & $\begin{array}{l}\text { Cross-sectional } \\
\text { survey }\end{array}$ & $\begin{array}{l}\text { This paper aimed to assess the knowledge of nurse-midwife educators on the major causes of maternal } \\
\text { mortality in Nigeria by administering a survey. The authors found that } 57.2 \% \text { of } 292 \text { educators could diagnose } \\
\text { pre-eclampsia. } 86 \% \text { knew about } \mathrm{MgSO}_{4} \text { but only } 16.8 \% \text { knew about using calcium gluconate as an antidote to } \\
\mathrm{MgSO}_{4} \text { toxicity. Nearly two thirds }(63.7 \%) \text { were unable to describe the steps of active management of third stage } \\
\text { labor. In addition to these, other knowledge gaps were identified relating to oxytocic use for hospital delivery, } \\
\text { when to perform episiotomies, and causes of postpartum haemorrhage. } \\
\text { The authors propose scale up of quality obstetric care by updating pre-service curricula in addition to in-service } \\
\text { appraisals and continuing education on these issues. }\end{array}$ \\
\hline $\begin{array}{l}\text { Okafor, U. (2009). Maternal and perinatal } \\
\text { outcome after caesarean delivery in } \\
\text { preeclampsia or eclampsia in Enugu, Nigeria: } \\
\text { four years on. International Journal of Obstetric }\end{array}$ & Correspondence & $\begin{array}{l}\text { This correspondence from Okafor provides a brief update on health outcomes following caesarean delivery of } \\
\text { women with PE/E and their babies. Based on a retrospective review of hospital cases of PE/E deliveries via CS } \\
\text { (1998-2002), the author previously recommended a multidisciplinary approach to management and increased }\end{array}$ \\
\hline
\end{tabular}




\begin{tabular}{|c|c|c|}
\hline Citation & Paper Type & Summary \\
\hline Anesthesia. & & $\begin{array}{l}\text { use of spinal anaesthesia. Here, the author looks at records from July } 2002 \text { to June } 2006 \text { to assess whether the } \\
\text { outcomes have improved for women with PE/E undergoing CS. } \\
\text { During the recent four year period, three eclamptics ( } 2 \text { spinal, } 1 \text { epidural), } 17 \text { severe PE (15 spinal, two epidural) } \\
\text { and } 10 \text { mild PE ( } 8 \text { spinal, } 2 \text { epidural) were delivered via CS. } \\
\text { Maternal outcomes were improved when compared to the prior study period; possibly due to the preference of } \\
\text { spinal anaesthesia (general anaesthesia is known to be associated with higher rates of maternal mortality and } \\
\text { morbidity). } \\
\text { Perinatal mortality was unchanged. } \\
\text { Definitions: } \\
\text { Mild preeclampsia: BP between } 140 / 90 \text { and } 160 / 110 \mathrm{mmHg} \text { on two occasions six hours or more apart, or a } \\
\text { rise from midtrimester values of } 3 \mathrm{mmHg} \text { in systolic or } 15 \mathrm{mmHg} \text { in diastolic BP, more than ).3g/L proteinuria on } \\
\text { two consecutive specimens and significant non-dependent oedema. } \\
\text { Severe PE: BP persistently above } 160 / 110 \mathrm{mmHg} \text {, proteinuria above } 5 \mathrm{~g} / 24 \text { hours and headache, blurred vision, } \\
\text { epigastric pain and oliguria. }\end{array}$ \\
\hline $\begin{array}{l}\text { Okereke, Ekechi, Babatunde Ahonsi, et al. } \\
\text { "Benefits of Using Magnesium Sulphate } \\
\text { (MgSO(4)) for Eclampsia Management and } \\
\text { Maternal Mortality Reduction: Lessons from } \\
\text { Kano State in Northern Nigeria." BMC research } \\
\text { notes } 5 \text { (2012). }\end{array}$ & Project description & $\begin{array}{l}\text { In 2012, } 33 \text { heath workers in five facilities in Jigawa state were selected and recruited to be mentors for junior } \\
\text { medical officers, nurses, midwives, CHOs and CHEWs to improve } \mathrm{MNCH} \text { service delivery. In February of } 2013 \text {, } \\
\text { this study conducted interviews with stakeholders (mentors, mentees, facility managers and state government } \\
\text { health officials) to assess perceptions about clinical mentoring as a strategy to improve } \mathrm{MNCH} \text { service delivery. } \\
\text { The clinical mentors and the healthcare workers in-charge of obstetrics saw changes regarding the introduction } \\
\text { and updating of treatment guidelines for basic emergency health services including using magnesium sulphate } \\
\text { to manage PE/E. This study concludes that clinical mentoring improved worker capacity to deliver quality MNCH } \\
\text { services and that by integrating mentorship into the district health system, it has the potential to promote } \\
\text { government ownership and sustainability. }\end{array}$ \\
\hline $\begin{array}{l}\text { Olamijulo, J., Ogedengbe, O., \& Giwa-Osagie, O. } \\
\text { (2008). Availability and use of obstetric } \\
\text { guidelines in Nigeria. International Journal of } \\
\text { Gynaecology and Obstetrics, 102(3), 242-245 }\end{array}$ & $\begin{array}{l}\text { Cross-sections } \\
\text { survey }\end{array}$ & $\begin{array}{l}\text { This survey was meant to assess the availability and use of obstetric guidelines by asking Ob/Gyns (at SOGON } \\
\text { Annual General Meeting and Scientific Conference) to respond to a self-administered questionnaire. One } \\
\text { hundred and seventy-eight responses were completed, but only } 176 \text { were able to be analyzed. Most ( } 83.5 \% \text { ) of } \\
\text { the respondents had over ten years' experience. The results showed that } 55.9 \% \text { of respondents reported that } \\
\text { guidelines for severe PE/E were in place, but only } 38.8 \% \text { said that they were used regularly. }\end{array}$ \\
\hline $\begin{array}{l}\text { Osungbade, K., \& Ige, O. (2011). Public health } \\
\text { perspectives of preeclampsia in developing } \\
\text { countries: implication for health system } \\
\text { strengthening. Journal of Pregnancy. }\end{array}$ & Review Article & $\begin{array}{l}\text { Literature review of papers published on PE/E in developing countries between } 2000 \text { and } 2010 \text {. Based on the } \\
\text { papers identified that reported numbers for Nigeria, prevalence of PE ranged from } 2-16.7 \% \text {. } \\
\text { Challenges identified include: managing PE, three delays to care, health policies. } \\
\text { Recommend: risk assessment and clinical management, society and community interventions, and health } \\
\text { system strengthening }\end{array}$ \\
\hline
\end{tabular}




\begin{tabular}{|c|c|c|}
\hline Citation & Paper Type & Summary \\
\hline $\begin{array}{l}\text { Tukur, J. (2009). The use of magnesium } \\
\text { sulphate for the treatment of severe pre- } \\
\text { eclampsia and eclampsia. Annals of African } \\
\text { Medicine, } 8(2), 76-80 \text {. }\end{array}$ & Literature review & $\begin{array}{l}\text { Tukur discusses the severity of maternal mortality due to } \mathrm{PE} / \mathrm{E} \text { in Nigeria and describes key issues related to } \\
\text { using magnesium sulphate He explains that while } \mathrm{MgSO}_{4} \text { was introduced in } 1925 \text { to manage convulsions it } \\
\text { wasn't until } 1995 \text { that its efficacy was confirmed by the Collaborative Eclampsia Trial (Magpie Trial). Despite its } \\
\text { now known efficacy, } \mathrm{MgSO}_{4} \text { remains mostly unavailable in developing countries where it is most needed. Tukur } \\
\text { goes on to describe the two predominant dosing regimens: Pritchard and Zuspan as well as the importance of } \\
\text { monitoring for toxicity. Choice of regimen depends on various factors including expertise and availability of staff } \\
\text { to administer the drug, (Pritchard is often preferred in low resource settings because it is a simple IM injection } \\
\text { that can be administered by lower cadre providers and doesn't require infusion pump). } \\
\text { Pritchard involves administering a loading dose bolus of } 4 \mathrm{~g} \text { of } \mathrm{MgSO}_{4} \text { via IV over } 5-10 \text { minutes and is followed } \\
\text { immediately by } 10 \mathrm{~g} \text { ( } 5 \mathrm{~g} \text { in each buttock) and subsequent maintenance doses of } 5 \mathrm{~g} \text { in alternate buttocks every } \\
\text { four hours. } \\
\text { Zuspan involves an initial IV dose of } 4 \mathrm{~g} \text { of } \mathrm{MgSO}_{4} \text { over } 5-10 \text { minutes followed by } 1-2 \mathrm{~g} \text { every hour by infusion } \\
\text { pump(a gravity fed infusion set can be used) } \\
\text { It is necessary to train providers on } \mathrm{MgSO}_{4} \text { use and ensure that protocols for its use are in place. Ensuring the } \\
\text { involvement of important stakeholders is essential to ensure availability and utilization of } \mathrm{MgSO}_{4}\end{array}$ \\
\hline
\end{tabular}




\section{Appendix VI:}

\section{SUMIMARY TABLES OF DESCRIPTIVE PAPERS ON HOSPITAL REPORTS}

\begin{tabular}{|c|c|c|c|c|}
\hline Citation & $\begin{array}{l}\text { Study } \\
\text { Design }\end{array}$ & $\begin{array}{l}\text { Location, Timeframe, and } \\
\text { Sample size }\end{array}$ & $\begin{array}{l}\text { Prevalence/ } \\
\text { Incidence/ } \\
\text { CFR }\end{array}$ & $\begin{array}{l}\text { Main findings/ limitations } \\
\text { Conclusions/ } \\
\text { Recommendations= }\end{array}$ \\
\hline $\begin{array}{l}\text { Abe, E., \& Omo-Aghoja, L. O. (2008). Maternal } \\
\text { mortality at the Central Hospital, Benin City } \\
\text { Nigeria: a ten year review. African Journal of } \\
\text { Reproductive Health, 12(3), 17-26. }\end{array}$ & $\begin{array}{l}\text { Retrospecti } \\
\text { ve review } \\
\text { of hospital } \\
\text { records. }\end{array}$ & $\begin{array}{l}\text { Obstetric unit of Central } \\
\text { Hospital, Benin City, } \\
\text { Nigeria } \\
\text { January } 1,1994 \text { - } \\
\text { December } 31,2003 \\
28,186 \text { deliveries }\end{array}$ & N/A & $\begin{array}{l}\text { - } 146 \text { maternal deaths over the } 10 \text { year period, overall maternal } \\
\text { mortality ratio of } 518 / 100,000 \text { total deliveries. } \\
\text { PE/E was fourth leading direct cause of maternal mortality, } \\
\text { contributing } 15.6 \% \text { of overall maternal deaths. } \\
\text { Training, retraining and continuing medical education on emergency } \\
\text { obstetric care, making maternal health care free, and reducing } \\
\text { poverty and increasing female education to reduce the burden of } \\
\text { maternal mortality. }\end{array}$ \\
\hline $\begin{array}{l}\text { Aboyeji, A., ljaiya, M., \& AAFawole. (2007). } \\
\text { Maternal mortality in a Nigerian teaching } \\
\text { hospital -- a continuing tragedy. Tropical Doctor, } \\
37(2), 83-85 .\end{array}$ & $\begin{array}{l}\text { Retrospecti } \\
\text { ve review } \\
\text { of hospital } \\
\text { records. }\end{array}$ & $\begin{array}{l}\text { University of llorin Teaching } \\
\text { Hospital, llorin, Nigeria } \\
\text { January 1, 1997- } \\
\text { December 31, } 2002 \\
\text { 13,092 live births }\end{array}$ & & $\begin{array}{l}\text { - } 108 \text { maternal deaths during the period, overall maternal mortality } \\
\text { ratio of } 825 / 100,000 \text { live births } \\
\text { - } \quad \text { Severe PE/E was most common cause of death (27.8\%) } \\
\text { "The emergence of severe pre-eclampsia/eclampsia as the common } \\
\text { most clinical cause of maternal death is not entirely surprising. [...] it } \\
\text { is also possible that this is so because more of the patients with the } \\
\text { condition are elderly and they may have other medical conditions such } \\
\text { as hypertension as an underlying disease. This will carry more } \\
\text { mortality than the straightforward eclampsia associated with } \\
\text { primigravidity." } \\
\text { MMR may be overestimated since this is a referral center and often } \\
\text { - } \quad \text { Rees complicated, high risk cases. } \\
\text { Recommendations: train TBAs to recognize obstetric emergencies, }\end{array}$ \\
\hline $\begin{array}{l}\text { Adamu, A., \& Ekele, B. (2012). Pregnancy } \\
\text { outcome in women with eclampsia at a tertiary } \\
\text { centre in northern Nigeria. African Journal of } \\
\text { Gynecology \& Obstetrics, 119(S3), S531-S867. }\end{array}$ & $\begin{array}{l}\text { Retrospecti } \\
\text { ve analysis } \\
\text { of } \\
\text { demograph } \\
\text { ic and } \\
\text { clinical } \\
\text { data of } \\
\text { patients } \\
\text { with } \\
\text { eclampsia }\end{array}$ & $\begin{array}{l}\text { Obstetrics \& Gynecology } \\
\text { department of Usmanu } \\
\text { Danfodiyo University } \\
\text { Teaching Hospital. } \\
\text { January 2000-December } \\
2009 . \\
1035 \text { eclamptics }\end{array}$ & $\begin{array}{l}\text { Incidence: } \\
1035 / 23,26 \\
6=4.4 \% \\
\text { CFR }=18 \%\end{array}$ & $\begin{array}{l}\text { Maternal mortality Ratio = 2670/100,000; } 26.7 \% \text { of which were } \\
\text { - } \quad \text { Intrappartum: } 62.6 \% \\
\text { Delivery method: spontaneous vaginal }=45.2 \% \text {; instrumental } \\
\text { deliveries }=28.7 \% \text {, destructive operations }=6.5 \% \text {, Caesarean section } \\
\text { was performed in } 19.6 \% \text { of the cases, } 6.1 \% \text { of eclamptic women died } \\
\text { undelivered. } \\
\text { - Women were more likely to die if they had not received antenatal care. } \\
\text { - Complications among women who died included: Aspiration } \\
\text { pneumonitis, pulmonary edema, hyperpyrexia, cerebral edema, acute } \\
\text { renal failure, disseminated intravascular coagulopathy, abruption } \\
\text { placentae, HELLP syndrome, and anesthetic complication } \\
\text { Over half of the maternal deaths occurred in the first } 24 \text { hours after } \\
\text { hospital admission. }\end{array}$ \\
\hline
\end{tabular}




\begin{tabular}{|c|c|c|c|c|}
\hline Citation & $\begin{array}{l}\text { Study } \\
\text { Design }\end{array}$ & $\begin{array}{l}\text { Location, Timeframe, and } \\
\text { Sample size }\end{array}$ & $\begin{array}{l}\text { Prevalence/ } \\
\text { Incidence/ } \\
\text { CFR }\end{array}$ & $\begin{array}{l}\text { Main findings/ limitations } \\
\text { Conclusions/ } \\
\text { Recommendations= }\end{array}$ \\
\hline & & & & $\begin{array}{l}\text { Fetal outcome: alive at discharge=59.2\%; fresh stillbirth=18.3\%' } \\
\text { macerated stillbirth= 14.7\%; early neonatal death=7.7\% }\end{array}$ \\
\hline $\begin{array}{l}\text { Adamu, Y. M., Salihu, H. M., Sathiakumar, N., \& } \\
\text { Alexander, G. R. (2003). Maternal mortality in } \\
\text { northern Nigeria: a population-based study. } \\
\text { European Journal of Obstetrics and Gynecology } \\
\text { and Reproductive Biology, 109(2), 153-159. }\end{array}$ & $\begin{array}{l}\text { Retrospecti } \\
\text { ve on vital } \\
\text { statistics } \\
\text { register }\end{array}$ & $\begin{array}{l}\text { Kano State, Research and } \\
\text { Statistics Department of } \\
\text { the Ministry of Health in } \\
\text { Kano State }\end{array}$ & $\begin{array}{l}\text { Eclampsia } \\
\text { causes } \\
31.3 \% \text { of all } \\
\text { maternal } \\
\text { deaths }\end{array}$ & $\begin{array}{l}\text { - } 4154 \text { maternal deaths out of 171,621 Maternal mortality ratio: } 2420 \\
\text { per } 100,000 \\
\text { - } \quad \text { delampsia was found to be the most important cause of maternal } \\
\text { deaths } \\
\text { "Phase I delay (delay in seeking appropriate treatment), in particular, } \\
\text { appears to be the rate-determining step along the non-biologic } \\
\text { pathway through which death precipitated by eclampsia occurs." } \\
\text { - } \quad \text { Recommend training staff in detecting and referring women at risk for } \\
\text { eclampsia (as well as anemia and ruptured uterus) during pregnancy. }\end{array}$ \\
\hline $\begin{array}{l}\text { Adelaja, L. M., \& Olufemi Taiwo, O. (2011). } \\
\text { Maternal and fetal outcome of obstetric } \\
\text { emergencies in a tertiary health institution in } \\
\text { South-Western Nigeria. ISRN Obstetrics and } \\
\text { Gynecology, } 2011 .\end{array}$ & $\begin{array}{l}\text { Retrospecti } \\
\text { ve study of } \\
\text { case } \\
\text { records }\end{array}$ & $\begin{array}{l}\text { Olabisi Onabanjo University } \\
\text { Teaching Hospital } \\
\text { (OOUTH), Sagamu, Nigeria } \\
\text { Jan } 2005 \text {-December } \\
2007 \\
262 \text { obstetric emergencies } \\
\text { out of } 1420 \text { deliveries }\end{array}$ & $\begin{array}{l}\text { Severe PIH: } \\
8.8 \% \text { of } \\
\text { obstetric } \\
\text { emergencie } \\
\text { s } \\
\text { Eclampsia: } \\
8.0 \% \text { of } \\
\text { obstetric } \\
\text { emergencie } \\
\mathrm{s}\end{array}$ & $\begin{array}{l}\text { - Obstetric emergencies accounted for } 70.6 \text { of the } 17 \text { maternal deaths } \\
\text { Prevention and effective management through ANC, personal financial } \\
\text { planning for pregnancy, development of adequate blood banking } \\
\text { system, regular training of doctors and nurses can go a long way to } \\
\text { reduce maternal and perinatal mortality in Nigeria. }\end{array}$ \\
\hline $\begin{array}{l}\text { Ade-Ojo, I., \& Loto, O. (2008). Outcome of } \\
\text { eclampsia at the Obafemi Awolowo University } \\
\text { Teaching Hospital Complex, Ile-lfe. Nigerian } \\
\text { Journal of Clinical Practice, 11(3), 279-284. }\end{array}$ & $\begin{array}{l}\text { Rerospecti } \\
\text { ve review } \\
\text { of case } \\
\text { records }\end{array}$ & $\begin{array}{l}\text { Obafemi Awolowo } \\
\text { University Teachin Hospital } \\
\text { Complex, lle-Ife, Nigeria } \\
\text { January } 1,1994- \\
\text { December 31, } 2003 \\
124 \text { cases of eclampsia }\end{array}$ & $\begin{array}{l}\text { Incidence of } \\
\text { elcampsia: } \\
0.91 \%\end{array}$ & $\begin{array}{l}\text { - } \quad \text { Eclampsia was highest among young adults }<25 \text { years of age, those } \\
\text { women carrying their first pregnancy, those who were unbooked. } \\
\text { - } \quad 62.5 \% \text { of cases occurred after } 36 \text { weeks gestation } \\
\text { - Common symptoms included: headache }(100 \%) \text {, hypertension }(75 \%) \\
\text { and fever }(20.2 \%) \\
\text { - } \quad \text { Antepartum eclampsia }(56.5 \%) \\
\text { - } \quad \text { Maternal mortality }=8.0 \% \text { and Perinatal mortality }=19.1 \% \\
\quad \text { aspidities include: acute renal failure, pulmonary edema, and } \\
\text { - } \quad \text { } 55.3 \%(n=69) \text { had emergency abdominal delivery } \\
\text { - } \quad \text { Recommendations include: strengthening essential obstetric care }\end{array}$ \\
\hline $\begin{array}{l}\text { Adeoye, I. A., Onayade, A. A., \& Fatusi, A. O. } \\
\text { (2013). Incidence, determinants and perinatal } \\
\text { outcomes of near miss maternal morbidity in lle- } \\
\text { Ife Nigeria: a prospective case control study. } \\
\text { BMC Pregnancy and Childbirth, 13(93), 8-10. }\end{array}$ & $\begin{array}{l}\text { Case- } \\
\text { control }\end{array}$ & $\begin{array}{l}\text { Maternity units of Obafemi } \\
\text { Awolowo University } \\
\text { teaching Hospitals } \\
\text { Complex, lle-lfe, Nigeria } \\
\text { July } 2006 \text {-June } 2007 \\
\text { *w/periods of interruption }\end{array}$ & $\begin{array}{l}\text { Hypertensiv } \\
\text { e disorders } \\
\text { of } \\
\text { pregnancy }= \\
37.3 \% \\
(\mathrm{n}=28) \text { of } \\
\text { near miss } \\
\text { cases } \\
\text { [severe }\end{array}$ & $\begin{array}{l}\text { - Maternal near miss was defined as "any woman who experienced a } \\
\text { life-threatening complication and who nearly died but for the hospital } \\
\text { care she received" and included cases of: haemorrhage, hypertensive } \\
\text { disorders in pregnancy, dystocia, infection, severe anemia. } \\
\text { Majority of near miss cases were not booked for ANC at tertiary facility } \\
(70.7 \%) \text { which was significantly different from proportion of controls } \\
\text { not booked for ANC at tertiary level ( } 27.0 \%) \\
\quad 37.3 \% \text { of near miss morbidities caused by hypertensive disorders in } \\
\text { pregnancy }\end{array}$ \\
\hline
\end{tabular}




\begin{tabular}{|c|c|c|c|c|}
\hline Citation & $\begin{array}{l}\text { Study } \\
\text { Design }\end{array}$ & $\begin{array}{l}\text { Location, Timeframe, and } \\
\text { Sample size }\end{array}$ & $\begin{array}{l}\text { Prevalence/ } \\
\text { Incidence/ } \\
\text { CFR }\end{array}$ & $\begin{array}{l}\text { Main findings/ limitations } \\
\text { Conclusions/ } \\
\text { Recommendations= }\end{array}$ \\
\hline & & 75 near miss, 300 controls & $\begin{array}{l}\mathrm{PE}=19(25.3 \\
\%) \\
\text { eclampsia= } \\
9(12.0 \%)]\end{array}$ & $\begin{array}{l}\text { Chronic hypertension found to have strongest association as a risk } \\
\text { factor for near misses ( } 7 \text { fold increase in risk). } \\
\text { Key determinants of near miss: phase I delay, chronic hypertension, } \\
\text { emergency caesarean section, and assisted vaginal delivery. }\end{array}$ \\
\hline $\begin{array}{l}\text { Adinma, E. D. (2012). Pattern of clinical } \\
\text { presentation of eclampsia at Nnamdi Azikiwe } \\
\text { University Teaching Hospital, Nnewi, } \\
\text { Southeastern Nigeria. Nigerian Journal of } \\
\text { Medicine, 21(3), 313-316. }\end{array}$ & $\begin{array}{l}\text { Retrospecti } \\
\text { ve study of } \\
\text { cases of } \\
\text { eclampsia }\end{array}$ & $\begin{array}{l}\text { Nnamdi Azikiwe University } \\
\text { Teaching Hospital, Nnewi, } \\
\text { Southeastern Nigeria } \\
\text { January } 1,2000- \\
\text { December } 31,2009 \\
6,262 \text { cases reviewed }\end{array}$ & $\begin{array}{l}\text { Prevalence } \\
\text { of } 0.91 \%\end{array}$ & 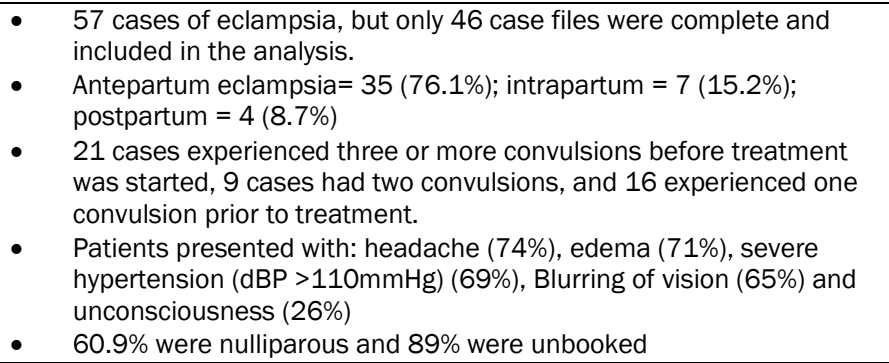 \\
\hline $\begin{array}{l}\text { Adinma, E. D. (2013). Maternal and perinatal } \\
\text { outcome of eclampsia in tertiary health } \\
\text { institution in Southeast Nigeria. Journal of } \\
\text { Maternal-Fetal and Neonatal Medicine, 26(2), } \\
211-214 .\end{array}$ & $\begin{array}{l}\text { Retrospecti } \\
\text { ve study of } \\
\text { cases of } \\
\text { eclampsia }\end{array}$ & $\begin{array}{l}\text { Nnamdi Azikiwe University } \\
\text { Teaching Hospital, Nnewi, } \\
\text { Southeastern Nigeria } \\
\text { January } 1,2000- \\
\text { December } 31,2009 \\
6,262 \text { cases reviewed }\end{array}$ & $\begin{array}{l}\text { Prevalence } \\
\text { of } 0.91 \% \\
\text { CFR: } 8 / 46= \\
17.4 \%\end{array}$ & $\begin{array}{l}\text { - } 57 \text { cases of eclampsia, but only } 46 \text { case files were complete and } \\
\text { included in the analysis. } 71.7 \% \text { of which were delivered by caesarean } \\
\text { section } \\
\text { - Morbidities include: pulmonary edema }(n=6) \text {, acute renal failure } \\
(n=4) \text {, coagulopathy }(n=3) \text { aspiration pneumonitis }(n-2) \text {, } \\
\text { cardiovascular accidents }(n=2) \text { and HELLP syndrome, septicemia and } \\
\text { cerebral edema occurred in } 1 \text { each. } \\
\text { - } \quad \text { Eight maternal deaths } \\
\text { - Perinatal outcomes: } 46 \text { women delivered } 51 \text { babies ( } 1 \text { set triplets and } \\
\text { three sets twins). } 82.5 \% \text { were premature, and } 70.6 \text { had low birth } \\
\text { weight } \\
\text { - } 13 \text { perinatal deaths }(25.5 \%)\end{array}$ \\
\hline $\begin{array}{l}\text { Agida, E. T., Adeka, B. I., \& Jibril, K. A. (2010). } \\
\text { Pregnancy outcome in eclamptics at the } \\
\text { University of Abuja Teaching Hospital, } \\
\text { Gwagwalada, Abuja: a } 3 \text { year review. Nigerian } \\
\text { Journal of Clinical Practice, 13(4), 394-398. }\end{array}$ & $\begin{array}{l}\text { Retrospecti } \\
\text { ve review } \\
\text { of case } \\
\text { notes }\end{array}$ & $\begin{array}{l}\text { University of Abuja } \\
\text { Teaching Hospital, } \\
\text { Gwagwalada, Abuja } \\
\text { Case note review, of } \\
\text { patients with eclampsia } \\
\text { from May } 1,2005 \text { and } \\
\text { April } 30,2008 \\
4471 \text { deliveries, } 59 \\
\text { eclampsia cases, } 46 \text { case } \\
\text { notes available }\end{array}$ & $\begin{array}{l}59 \text { cases of } \\
\text { eclampsia; } \\
\text { incidence of } \\
13 \text { per } \\
1,000 \\
\text { deliveries } \\
\text { CFR: } 8.5 \% \\
\text { Stillbirth } \\
\text { rate: } 2 \text { per } \\
1,000 \\
\text { deliveries }\end{array}$ & $\begin{array}{l}\text { - } \quad \text { At the time, this facility used the Zuspan regimen } \\
\text { Eclampsia was most common among } 20-24 \text { year olds (34.8\%). } 60.9 \% \\
\text { of eclampsia cases were in women } 20-29 \text { years old } \\
60.9 \% \text { were primigravidae } \\
\text { - } \quad 22(47.8 \% \text { ) had proteinuria of } 3+, 3(6.5 \%) \text { had no proteinuria } \\
\text { - } 20 \text { were managed with diazepam and } 19 \text { were managed with MgSO4; } \\
\text { only three patients had recurrent seizures } \\
\text { - } 39 \text { were delivered by caesarean, } 5 \text { vaginally ( } 1 \text { of whom delivered } \\
\text { elsewhere and was referred when she developed eclampsia } \\
\text { postpartum), and } 1 \text { died undelivered. } \\
\text { Complications included: acute renal failure (6 patients) } 3 \text { of whom } \\
\text { died (though } 5 \text { maternal deaths due to eclampsia were recorded, the } \\
\text { case notes were only available for three). }\end{array}$ \\
\hline
\end{tabular}




\begin{tabular}{|c|c|c|c|c|}
\hline Citation & $\begin{array}{l}\text { Study } \\
\text { Design }\end{array}$ & $\begin{array}{l}\text { Location, Timeframe, and } \\
\text { Sample size }\end{array}$ & $\begin{array}{l}\text { Prevalence/ } \\
\text { Incidence/ } \\
\text { CFR }\end{array}$ & $\begin{array}{l}\text { Main findings/ limitations } \\
\text { Conclusions/ } \\
\text { Recommendations= }\end{array}$ \\
\hline & & & & $\begin{array}{l}\text { - } 37 \text { babies were delivered alive, ( } 6 \text { of whom were <1500g; } 14 \text { were } \\
2500 \mathrm{~g}>\text { but }>1500 \mathrm{~g} \text {; and } 16 \text { were }>2500 \mathrm{~g}) 8 \text { stillbirths }\end{array}$ \\
\hline $\begin{array}{l}\text { Alabi, O. O., Olarunfemi, G., \& Onile, T. G. (2012). } \\
\text { The trend in maternal mortality in an upgraded } \\
\text { tertiary facility in North Central Nigeria. Nigerian } \\
\text { Journal of Medicine : Journal of the National } \\
\text { Association of Resident Doctors of Nigeria, } \\
\text { 21(3), 282-289. }\end{array}$ & $\begin{array}{l}\text { Retrospecti } \\
\text { ve review } \\
\text { of case } \\
\text { records }\end{array}$ & $\begin{array}{l}\text { Federal Medical Centre, } \\
\text { Lokoja, Kogi } \\
\text { Jan } 1,2005 \text { - December } \\
31,2009 \\
44 \text { maternal deaths } \\
\text { reviewed }\end{array}$ & $\begin{array}{l}\text { Hypertensiv } \\
\text { e disorders } \\
\text { causes } \\
31.8 \% \text { of } \\
\text { maternal } \\
\text { deaths }\end{array}$ & $\begin{array}{l}\text { - } \quad \text { MMR during this period at the facility was } 463 \text { per } 100,000 \text { live births } \\
\text { - } \quad \text { DE/E accounted for } 14 \text { of the } 44 \text { maternal deaths } \\
\text { During the study period, MgSO4 was unavailable at the facility; since } \\
\text { its introduction at the center in Oct } 2009 \text {, no one has died from PE/E }\end{array}$ \\
\hline $\begin{array}{l}\text { Bukar, M., Kunmanda, V., Moruppa, J., Ehalaiye, } \\
\text { B., Takai, U., \& Ndonya, D. (2013). Maternal } \\
\text { mortality at federal medical centre yola, } \\
\text { adamawa state: a five-year review. Annals of } \\
\text { Medical and Health Sciences Research, 3(4), } \\
\text { 568-571. }\end{array}$ & $\begin{array}{l}\text { Retrospecti } \\
\text { ve study of } \\
\text { maternal } \\
\text { deaths }\end{array}$ & $\begin{array}{l}\text { Federal Medical Centre } \\
\text { Yola. } \\
\text { January 2007-December } \\
2011 \\
28 \text { case files of maternal } \\
\text { deaths }\end{array}$ & N/A & $\begin{array}{l}\text { - } 54 \text { maternal deaths among } 8497 \text { deliveries: MMR= } 636 \text { per } 100,000 \\
\text { deliveries; } 33 \text { files were retrieved and } 28 \text { were complete for analysis. } \\
\text { - Leading cause of maternal death was PE/E ( } 32.1 \% \text { of } 28) \text {-all of those } \\
\text { who died of PE/E had not attended ANC, were Muslim and Hausa or } \\
\text { Fulani. }\end{array}$ \\
\hline $\begin{array}{l}\text { Buowari, Y. (2013). Pattern and Outcome of } \\
\text { Eclampsia Managed at a General Hospital in } \\
\text { North-West Nigeria. Nigerian Health Journal. }\end{array}$ & $\begin{array}{l}\text { Retrospecti } \\
\text { ve study of } \\
\text { eclampsia } \\
\text { patients }\end{array}$ & $\begin{array}{l}\text { General Hospital Aliero, } \\
\text { Kebbi state, Nigeria } \\
\text { December } 2004 \text { to } \\
\text { November } 2006 \\
58 \text { records }\end{array}$ & & $\begin{array}{l}\text { - } 47 \text { antepartum or intrapartum; } 11 \text { postpartum eclampsia } \\
\text { - } \quad \text { f those } 47,31 \text { ( } 66 \%) \text { were delivered by caesarean and } 44 \text { (75.86\%) } \\
\text { survived and were discharged } \\
\text { - } 37 \text { babies survived, } 6 \text { were fresh stillbirths and } 4 \text { were caveated } \\
\text { stillbirths. } \\
\text { - At the time of the cases, diazepam was the only anticonvulsant } \\
\text { available }\end{array}$ \\
\hline $\begin{array}{l}\text { Chigbu, B., Onwere, S., Kamanu, C., Aluka, C., } \\
\text { Okoro, O., \& E, A. (2009). Pregnancy outcome in } \\
\text { booked and unbooked mothers in South Eastern } \\
\text { Nigeria. East African Medical Journal, 86(6), } \\
267-271 .\end{array}$ & $\begin{array}{l}\text { Hospital } \\
\text { based } \\
\text { retrospecti } \\
\text { ve study }\end{array}$ & $\begin{array}{l}\text { Abia State University } \\
\text { Teaching Hospital, Aba, } \\
\text { Nigeria } \\
\text { January 1, 2005- } \\
\text { December 31, } 2007 \\
\text { 3,734 mothers who } \\
\text { delivered }\end{array}$ & $\begin{array}{l}\text { Incidence } \\
\text { (unbooked): } \\
7.9 \% \\
\text { Incidence } \\
\text { (booked): } \\
2.0 \% \\
\text { Overall } \\
\text { incidence: } \\
3.0 \%\end{array}$ & $\begin{array}{l}\text { - Unbooked mothers had statistically higher incidence of PE/E (OR } \\
\text { 3.88; } 95 \% \mathrm{Cl} 2.61-5.77 \text { ) } \\
\text { Eclampsia caused } 9 \text { deaths among unbooked women and } 6 \text { among } \\
\text { booked women } \\
\text { - Unbooked mothers in this study were generally younger, with lower } \\
\text { educational status and higher probability of being unmarried. }\end{array}$ \\
\hline $\begin{array}{l}\text { Ebeigbe, P., \& Aziken, M. (2010). Early onset } \\
\text { pregnancy induced hypertension/eclampsia in } \\
\text { Benin City, Nigeria. Nigerian Journal of Clinical } \\
\text { Practice. }\end{array}$ & $\begin{array}{l}\text { Retrospecti } \\
\text { ve study of } \\
\text { hospital } \\
\text { cases }\end{array}$ & $\begin{array}{l}\text { University of Benin } \\
\text { Teaching Hospital, Benin } \\
\text { City, Nigeria }\end{array}$ & & $\begin{array}{l}\text { - } \quad \text { Early onset pregnancy induced hypertension/eclampsia contributed } \\
6.3 \% \text { of all HDP cases ( } 1 \text { per } 141 \text { deliveries) } \\
\text { - } \quad 58.7 \% \text { of HDP cases were delivered by caesarean section } \\
\text { - } \quad \text { Perinatal survival rate was } 34.0 \% \text {, }\end{array}$ \\
\hline
\end{tabular}




\begin{tabular}{|c|c|c|c|c|}
\hline Citation & $\begin{array}{l}\text { Study } \\
\text { Design }\end{array}$ & $\begin{array}{l}\text { Location, Timeframe, and } \\
\text { Sample size }\end{array}$ & $\begin{array}{l}\text { Prevalence/ } \\
\text { Incidence/ } \\
\text { CFR }\end{array}$ & $\begin{array}{l}\text { Main findings/ limitations } \\
\text { Conclusions/ } \\
\text { Recommendations= }\end{array}$ \\
\hline & & $\begin{array}{l}\text { March 1, } 2000 \text {-February } \\
28,2005\end{array}$ & & $\begin{array}{l}\text { - This study suggests that aggressive management (stabilization and } \\
\text { early delivery) of early onset severe PE is associated with good } \\
\text { outcomes for mother but poor perinatal outcomes. Conservative } \\
\text { management should be only used in well-equipped facilities that have } \\
\text { the resources and capacity for close monitoring and urgent response. }\end{array}$ \\
\hline $\begin{array}{l}\text { Efetie, E. R., \& Okafor, U. V. (2007). Maternal } \\
\text { outcome in eclamptic patients in Abuja, Nigeria-- } \\
\text { a } 5 \text { year review. Nigerian Journal of Clinical } \\
\text { Practice, 10(4), 309-313. }\end{array}$ & $\begin{array}{l}\text { Retrospecti } \\
\text { ve analysis } \\
\text { of medical } \\
\text { records }\end{array}$ & $\begin{array}{l}\text { National Hospital, Abuja } \\
\text { March 1, 2000-February } \\
28,2005\end{array}$ & $\begin{array}{l}\text { Incidence } \\
7.8 \text { cases of } \\
\text { eclampsia } \\
\text { per } 1000 \\
\text { deliveries } \\
\text { CFR }=28.3 \%\end{array}$ & $\begin{array}{l}\text { Eclampsia occurred most often in unbooked, nulliparous mothers, } \\
71.5 \% \text { of cases were delivered by caesarean due to 'unfavourable } \\
\text { cervix' } \\
58.7 \% \text { of cases occurred antepartum, } 26.1 \% \text { were postpartum and } \\
15.2 \% \text { were intrapartum } \\
\text { - } \quad \text { Diazepam was used to control fits, MgSO4 was only used in two } \\
\text { cases. } \\
\text { Hydrallazine was used to control hypertensive (particularly in ICU) } \\
\text { while Nifedipine and Methyldopa were used when BP was better } \\
\text { controlled } \\
19 \text { developed complications including (HELLP syndrome, acute renal } \\
\text { failure, disseminated intravascular coagulation, septicaemia, lobar } \\
\text { pneumonia, pulmonary edema, cerebral hemorrhage, cerebral } \\
\text { damage and quadriplegia. } \\
13 \text { maternal deaths, } 46.2 \% \text { due to HELLP syndrome } \\
\text { - }\end{array}$ \\
\hline $\begin{array}{l}\text { Eke, A. C., Ezebialu, I. U., \& Okafor, C. (2011). } \\
\text { Presentation and outcome of eclampsia at a } \\
\text { tertiary center in South East Nigeria-a 6-year } \\
\text { review. Hypertension in Pregnancy, 30(2), 125- } \\
132 .\end{array}$ & $\begin{array}{l}\text { Retrospecti } \\
\text { ve study of } \\
\text { case notes }\end{array}$ & $\begin{array}{l}\text { Nnamdi Azikiwe University } \\
\text { Teaching Hospital, Nnewi, } \\
\text { Anambra state, Nigeria } \\
2004-2009 \\
212 \text { case notes of } \\
\text { eclampsia patients }\end{array}$ & $\begin{array}{l}\text { Prevalence= } \\
1.57 \% \\
\text { CFR } 7.5 \%\end{array}$ & $\begin{array}{l}\text { - } \quad 24.5 \% \text { of eclamptic patients were unbooked } \\
\text { - } \quad \text { Most commonly affected women were nulliparous teenagers }(60.4 \%) \text {. } \\
\text { - } 12 \text { neonatal and } 8 \text { perinatal deaths }\end{array}$ \\
\hline $\begin{array}{l}\text { Ekele, B., Bello, S., \& Adamu, A. (2007). Clusters } \\
\text { of eclampsia in a Nigerian teaching hospital. } \\
\text { International Journal of Gynecology and } \\
\text { Obstetrics, 96(1), 62-66. }\end{array}$ & $\begin{array}{l}\text { Retrospecti } \\
\text { ve cohort }\end{array}$ & $\begin{array}{l}\text { Usmanu Danfodiyo } \\
\text { University Teaching } \\
\text { Hospital, Sokoto, Nigeria } \\
\text { Jan 1, 1995-December } \\
\text { 31, } 2004 \\
\text { Reviewed files of 15,318 } \\
\text { deliveries over the period }\end{array}$ & $\begin{array}{l}\text { Overall } \\
\text { prevalence: } \\
4.29 \% \\
\text { Incidence at } \\
\text { the } \\
\text { beginning of } \\
\text { the study } \\
\text { period: } \\
0.39 \% \\
(1995) \text { and } \\
\text { increased to } \\
7.0 \% \text { (2004) }\end{array}$ & $\begin{array}{l}\text { - Cases were defined as "maternities that presented with fitting or fitted } \\
\text { while on admission, had blood pressure equal to or greater than } \\
140 / 90 \mathrm{mmHg} \text { at least } 2+\text { proteinuria with or without edema, and had } \\
\text { no past history of epilepsy." } \\
26.3 \% \text { were antepartum, } 67.3 \% \text { were intrapartum and } 6.4 \text { were } \\
\text { postpartum. } 95.4 \% \text { patients were unbooked. } 75.8 \% \text { were primigravida } \\
\text { - Incidence increased significantly over the study period with peaks } \\
\text { identified in 1996, } 2001 \text { and } 2004 \text {. (Each is twice about twice the } \\
\text { expected/projected rate for that time.) } \\
\text { Factors that may have caused UDUTH to receive more cases of } \\
\text { eclampsia: it is the only tertiary facility in the area and would receive } \\
\text { more difficult cases and the facility's participation in the Magpie Trial } \\
\text { meaning they had MgSO4 and clinicians in nearby facilities were } \\
\text { aware which might have encouraged selective referral of women PE/E }\end{array}$ \\
\hline
\end{tabular}




\begin{tabular}{|c|c|c|c|c|}
\hline Citation & $\begin{array}{l}\text { Study } \\
\text { Design }\end{array}$ & $\begin{array}{l}\text { Location, Timeframe, and } \\
\text { Sample size }\end{array}$ & $\begin{array}{l}\text { Prevalence/ } \\
\text { Incidence/ } \\
\text { CFR }\end{array}$ & $\begin{array}{l}\text { Main findings/ limitations } \\
\text { Conclusions/ } \\
\text { Recommendations= }\end{array}$ \\
\hline & & & & $\begin{array}{l}\text { to UDUTH. Also many of the risk factors for PE/E are common in this } \\
\text { area. }\end{array}$ \\
\hline $\begin{array}{l}\text { El-Nafaty, A., Melah, G., Massa, A., Audu, B., \& } \\
\text { Nelda, M. (2004). The analysis of eclamptic } \\
\text { morbidity and mortality in the Specialist Hospital } \\
\text { Gombe, Nigeria. Journal of Obstetrics and } \\
\text { Gynaecology, 24(2), 142-147. }\end{array}$ & $\begin{array}{l}\text { Retrospecti } \\
\text { ve case } \\
\text { review }\end{array}$ & $\begin{array}{l}\text { Specialist Hospital Gombe } \\
\text { January 1, 1997- } \\
\text { December 31, } 1999 \\
302 \text { cases of eclampsia }\end{array}$ & $\begin{array}{l}\text { Incidence of } \\
3.9 \% \\
\text { CFR }=11.6 \%\end{array}$ & $\begin{array}{l}\text { - } \quad \text { Eclampsia occurred intrapartum in } 55 \% \text { of the patients } \\
\text { - } 90 \% \text { of cases experienced headache, blurred vision, and epigastric } \\
\text { pain prior to first seizure } \\
\text { dBP }>110 \text { mmHg was recorded in } 33.8 \% \\
66.9 \% \text { were teenagers, } 73.5 \% \text { were primigravidae, spontaneous } \\
\text { vaginal delivery occurred in } 52.6 \% \text { (40.4\% were caesarean section) } \\
\text { - } 111 \text { perinatal deaths ( } 36.8 \%) \text { (108 were due to eclampsia, the other } \\
6 \text { had congenital anomalies) } \\
\text { Of the } 216 \text { live births, } 40 \% \text { were preterm } \\
\text { - Morbidities included: pyrexis (7.3\%), postpartum hemorrhage }(4.6 \%) \\
\text { abruption (2.7\%), and others at lower frequency }\end{array}$ \\
\hline $\begin{array}{l}\text { Fabamwo, A., Akinola, O., Tayo, A., Gbadegesin, } \\
\text { A., Kushemiju, O., \& Oyedele, Y. (2007). Socio- } \\
\text { Demographic Characteristics of Eclamptic } \\
\text { Patients at a Tertiary Institution in Lagos Nigeria. } \\
\text { Nigerian Medical Practitioner, 52(4). }\end{array}$ & $\begin{array}{l}\text { Retrospecti } \\
\text { ve review }\end{array}$ & $\begin{array}{l}\text { Department of Obstetrics } \\
\text { and Gynaecology, Lagos } \\
\text { State University Teaching } \\
\text { Hospital, Ikeja, Lagos State } \\
\text { January 1, 1999- } \\
\text { December 31, } 2003 \\
\text { 12,875 deliveries }\end{array}$ & $\begin{array}{l}\text { Incidence = } \\
1.66 \% \\
\text { eclampsia }\end{array}$ & $\begin{array}{l}\text { - } 65.4 \% \text { of cases were nulliparous, incidence was highest for women } \\
\text { under } 30 \\
\text { Unbooked, young, nulliparous women were found to be most prone to } \\
\text { developing eclampsia, recommend targeting this group to attend ANC } \\
\text { regularly. }\end{array}$ \\
\hline $\begin{array}{l}\text { Igberase, G., \& Ebeigbe, P. (2006). Eclampsia: } \\
\text { Ten-years of experience in a rural tertiary } \\
\text { hospital in the Niger delta, Nigeria. Journal of } \\
\text { Obstetrics and Gynaecology, 26(5), 414-417. }\end{array}$ & $\begin{array}{l}\text { Descriptive } \\
\text { review of } \\
\text { hospital } \\
\text { cases }\end{array}$ & $\begin{array}{l}\text { Baptist Medical Centre } \\
\text { (BMC), Eku, Delta State } \\
\text { January } 1,1994- \\
\text { December } 31,2003 \\
123 \text { cases of eclampsia }\end{array}$ & $\begin{array}{l}\text { Incidence of } \\
\text { eclampsia: } \\
2.3 \%\end{array}$ & $\begin{array}{l}\text { - } 17(13.8 \%) \text { of women with eclampsia were unbooked. Teenagers } \\
\text { accounted for } 21.1 \$ \text { of cases. } \\
\text { Most common symptoms were: headache (78\%), blurring of vision } \\
\text { (57.7\%), vomiting ( } 29.3 \%) \text {, epigastric pain (19.5\%), and dizziness } \\
\text { (55.3\%) } \\
68 \% \text { of the patients began experiencing seizures antepartum, } 23.6 \% \\
\text { intrapartum, and } 8.2 \% \text { postpartum }\end{array}$ \\
\hline $\begin{array}{l}\text { Igberase, G., \& Ebeigbe, P. (2007). Maternal } \\
\text { mortality in a rural referral hospital in the Niger } \\
\text { Delta, Nigeria. JOURNAL OF OBSTETRICS AND } \\
\text { GYNAECOLOGY, 27(3), 275-278. }\end{array}$ & $\begin{array}{l}\text { Maternal } \\
\text { death audit }\end{array}$ & $\begin{array}{l}\text { Baptist Medical Centre } \\
\text { (BMC), Eku, Delta State } \\
\text { January 1, 1994- } \\
\text { December 31, } 2003 \\
5,153 \text { deliveries, } 115 \\
\text { maternal deaths }\end{array}$ & CFR: $15.4 \%$ & 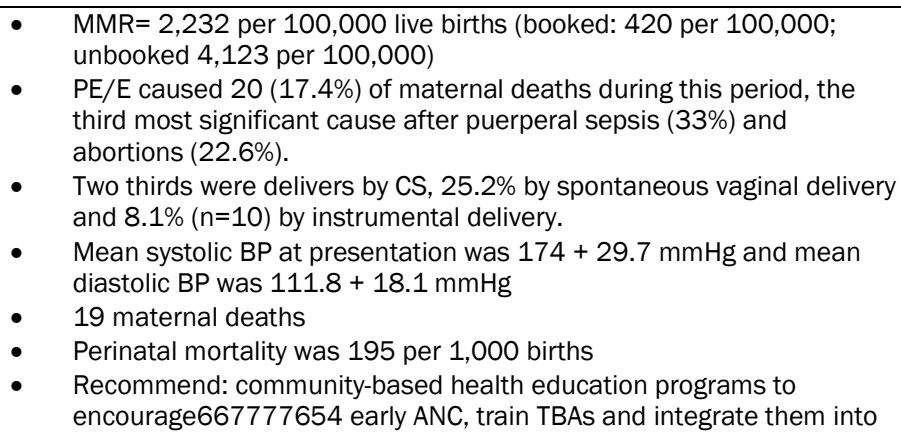 \\
\hline
\end{tabular}




\begin{tabular}{|c|c|c|c|c|}
\hline Citation & $\begin{array}{l}\text { Study } \\
\text { Design }\end{array}$ & $\begin{array}{l}\text { Location, Timeframe, and } \\
\text { Sample size }\end{array}$ & $\begin{array}{l}\text { Prevalence/ } \\
\text { Incidence/ } \\
\text { CFR }\end{array}$ & $\begin{array}{l}\text { Main findings/ limitations } \\
\text { Conclusions/ } \\
\text { Recommendations= }\end{array}$ \\
\hline & & & & $\begin{array}{l}\text { primary healthcare team, improve referrals and capacity of tertiary } \\
\text { institutions to provide intensive care for eclamptic patients. }\end{array}$ \\
\hline $\begin{array}{l}\text { Ikechebelu, J., \& Okoli, C. (2002). Review of } \\
\text { eclampsia at the Nnamdi Azikiwe University } \\
\text { teaching hospital, Nnewi (January 1996- } \\
\text { December 2000). Journal of Obstetrics and } \\
\text { Gynaecology, 22(3), 287-290. }\end{array}$ & $\begin{array}{l}\text { Retrospecti } \\
\text { ve case } \\
\text { review }\end{array}$ & $\begin{array}{l}\text { Nnamdi Azikiwe University } \\
\text { Teaching Hospital, Nnewi } \\
\text { January 1996-December } \\
2000 \\
43 \text { cases of eclampsia }\end{array}$ & $\begin{array}{l}\text { Incidence of } \\
\text { eclampsia: } \\
\text { 0.75\% } \\
\text { CFR } 9.3 \%\end{array}$ & $\begin{array}{l}\text { - } \quad 65 \% \text { were primigravidae, } 83.7 \% \text { were unbooked, } 81.4 \% \text { were under } \\
30 \text { years of age, mean age was } 23.5 \text { years } \\
\text { - } 24(55.8 \%) \text { had eclamptic fits antepartum, } 11 \text { (25.6\%) intrapartum } \\
\text { and } 8(18.6 \%) \text { postpartum. } \\
\text { - No fits occurred below BP of } 150 / 90 \mathrm{mmHg} \\
\text { - } 100 \% \text { were treated with diazepam; break-through seizures were } \\
\text { controlled with diazepam, and IV paraldehyde was used in one patient } \\
\text { who was not responding well to diazepam. } \\
\text { - } \quad \text { All } 43 \text { patients received Hydrallazine to control blood pressure } \\
\text { - } \quad \text { Sate of caesarean section was } 85.7 \% \text {, } \\
\text { and the other five were stillborn before arriving at the facility) } \\
\text { Health education, ANC, women's awareness of obstetric services, } \\
\text { early diagnosis and treatment, protocols for management of fluid } \\
\text { balance, antihypertensive, and anticonvulsive therapies are necessary } \\
\text { to reduce morbidity, mortality and high rates of CS. }\end{array}$ \\
\hline $\begin{array}{l}\text { Jido, T. (2012). Ecalmpsia: maternal and fetal } \\
\text { outcome. African Health Sciences, 12(2), 148- } \\
\text { 152. }\end{array}$ & $\begin{array}{l}\text { Prospectiv } \\
\text { e hospital } \\
\text { case } \\
\text { review }\end{array}$ & $\begin{array}{l}\text { Aminu Kano Teaching } \\
\text { Hospital, Kano, Nigeria } \\
120 \text { cases of eclampsia }\end{array}$ & $\begin{array}{l}\text { Incidence of } \\
\text { eclampsia } \\
1.2 \% \\
\text { CFR: } 11.7 \%\end{array}$ & $\begin{array}{l}\text { Maternal complications in eclamptic patients: prolonged } \\
\text { unconsciousness: } 13(10.8 \%) ; \text { acute renal failure: } 6(5.0 \%) \text {, } \\
\text { cerebrovascular accident } 5(4.2 \%) \text {, HELLP syndrome: } 5(4.2 \%) \text { and } \\
\text { others including: pulmonary oedema/pneumonia, coagulopathy, } \\
\text { abruptio placenta, cortical blindness, cardiomegaly, vesicovaginal } \\
\text { fistula } \\
\text { - } 14 \text { maternal deaths due to eclampsia } \\
\text { Perinatal outcomes in eclamptic mothers: stillbirth: } 27(22.5 \%) \text {, birth } \\
\text { asphyxia: } 47(39.1 \%) ; \text { low birth weight: } 31(25.8 \%) ; \text { admission to } \\
\text { nursery: } 19(15.0 \%)\end{array}$ \\
\hline $\begin{array}{l}\text { Kullima, A. A., Kawuwa, M. B. M., Audu, B. M., } \\
\text { Geidam, A. D., \& Mairiga, A. G. (2009). Trends in } \\
\text { maternal mortality in a tertiary institution in } \\
\text { Northern Nigeria. Annals of African Medicine, } \\
8(4), 221-224 .\end{array}$ & $\begin{array}{l}\text { Retrospecti } \\
\text { ve review } \\
\text { hospital } \\
\text { files }\end{array}$ & $\begin{array}{l}\text { Federal Medical Centre, } \\
\text { Nguru } \\
\text { January 1, 2003- } \\
\text { December 31, 2007 } \\
112 \text { case notes from } \\
\text { maternal deaths }\end{array}$ & N/A & $\begin{array}{l}\text { - } \quad \text { MMR 2,849 per } 100,000 \text { deliveries } \\
\text { Eclampsia persistently was the leading cause of death ( } 46.4 \% \text { of all } \\
\text { deaths during the period) } \\
\text { Grandmultiparas, illiteracy and lack of prompt ANC were significant } \\
\text { contributors in this study }\end{array}$ \\
\hline $\begin{array}{l}\text { Mairiga, A., \& Saleh, W. (2009). Maternal } \\
\text { mortality at the State Specialist Hospital Bauchi, } \\
\text { Northern Nigeria. East African Medical Journal, } \\
86(1), 25-30 .\end{array}$ & $\begin{array}{l}\text { Prospectiv } \\
\text { e analysis } \\
\text { of }\end{array}$ & $\begin{array}{l}\text { State Specialist Hospital, } \\
\text { Bauchi, Nigeria }\end{array}$ & $\mathrm{N} / \mathrm{A}$ & $\begin{array}{l}\text { - } \quad \text { MMR }=1,732 \text { per } 100,000 \text { live births } \\
\text { - } \quad 81 \% \text { of maternal deaths were in unbooked deliveries } \\
\text { - Severe PE/E accounted for } 31.9 \% \text { ( } n-245 \text { ) of maternal deaths } \\
\text { (followed by obstetric haemorrhage and sepsis) }\end{array}$ \\
\hline
\end{tabular}




\begin{tabular}{|c|c|c|c|c|}
\hline Citation & $\begin{array}{l}\text { Study } \\
\text { Design }\end{array}$ & $\begin{array}{l}\text { Location, Timeframe, and } \\
\text { Sample size }\end{array}$ & $\begin{array}{l}\text { Prevalence/ } \\
\text { Incidence/ } \\
\text { CFR }\end{array}$ & $\begin{array}{l}\text { Main findings/ limitations } \\
\text { Conclusions/ } \\
\text { Recommendations= }\end{array}$ \\
\hline & $\begin{array}{l}\text { maternal } \\
\text { mortality }\end{array}$ & $\begin{array}{l}\text { January } 1,2001- \\
\text { December } 31,2007 \\
767 \text { maternal deaths }\end{array}$ & & $\begin{array}{l}\text { Updating management policy for eclampsia and focus on increasing } \\
\text { quality of emergency obstetric care can help reduce maternal death } \\
\text { as well as use of magnesium sulphate and training providers from } \\
\text { referring facilities on how to use it. Improving blood banking and } \\
\text { transfusions can also help women in this community survive. }\end{array}$ \\
\hline $\begin{array}{l}\text { Makinde, O. N. (2011). The Contribution of } \\
\text { Severe Pre-Eclampsia and Eclampsia to } \\
\text { Perinatal Mortality in a Nigerian Teaching } \\
\text { Hospital. In D. O. Ezechi (Ed.), Perinatal } \\
\text { Mortality. }\end{array}$ & cohort & $\begin{array}{l}\text { Obafemi Awolowo } \\
\text { University Teaching } \\
\text { Hospitals Complex, Ile-Ife, } \\
\text { Nigeria } \\
\text { January 1, 2006-January } \\
31,2007 \\
39 \text { cases of severe PE/E }\end{array}$ & & $\begin{array}{l}\text { Each patient was categorized into three categories: } \\
16(41.02 \%) \text { Severe PE: hypertension after } 20 \mathrm{th} \text { week, } \\
\text { dBP }>110 \mathrm{mmHg} \text { on admission, proteinuria }>30 \mathrm{mg} / \mathrm{dl} \text { in random urine } \\
\text { specimen or }>300 \mathrm{mg} \text { in } 24 \mathrm{hr} \\
\text { - } 11(28.2 \%) \text { Imminent eclampsia: all parameters in (1) plus headache, } \\
\text { blurring of vision and upper abdominal pain } \\
\text { - } \quad 6(15.4 \%) \text { Eclampsia: all parameters in (1) and seizures. } \\
\text { - Six perinatal deaths (13.95\%) (among four cases), three early } \\
\text { neonatal deaths were a set of triplets. Overall perinatal mortality rate } \\
\text { attributable to a single disease entity (severe PE/E) was } 5.84 \text { per } \\
\text { 1000 births } \\
\text { The author recommends that in this setting, the Pre-eclampsia } \\
\text { community Guidelines (PRECOG) would minimize incidence and } \\
\text { complications of 'SPEE" (severe PE/E) }\end{array}$ \\
\hline $\begin{array}{l}\text { Mbachu, I. I., Udigwe, G. O., Okafor, C. I., } \\
\text { Umeonunihu, O. S., Ezeama, C., Eleje, G. U., \& } \\
\text { GU, M. I. U. G. O. C. U. O. E. C. E. (2013). The } \\
\text { pattern and obstetric outcome of hypertensive } \\
\text { disorders of pregnancy in Nnewi, Nigeria. } \\
\text { Nigerian Journal of Medicine, 22(2), 117-122. }\end{array}$ & $\begin{array}{l}\text { Descriptive } \\
\text { retrospecti } \\
\text { ve review }\end{array}$ & $\begin{array}{l}\text { Nnamdi Azikiwe University } \\
\text { Teaching Hospital, Nnewi, } \\
\text { Nigeria } \\
\text { January 2004-December } \\
2008 \\
4026 \text { deliveries }\end{array}$ & $\begin{array}{l}3.7 \% \\
\text { incidence of } \\
\text { hypertensive } \\
\text { disorders in } \\
\text { pregnancy. } \\
\text { CFR: } 5.6 \%\end{array}$ & $\begin{array}{l}\text { - } 148 \text { women managed for hypertensive disorders in pregnancy; } 138 \\
\text { complete folders were available for analysis } \\
64(46.4 \%) \text { had PE, } 50 \text { of whom had "severe" PE; } 28(20.3 \%) \text { had } \\
\text { eclampsia; } 7(5.1 \%) \text { had Chronic hypertension; } 14(10.1 \% \text { had chronic } \\
\text { hypertension with superimposed preeclampsia; } 17(12.3 \%) \text { had } \\
\text { unclassified hypertension. } \\
\text { Booking status and severity of disease were important determinants } \\
\text { of maternal and neonatal outcome in this study }\end{array}$ \\
\hline $\begin{array}{l}\text { Melah, G., Massa, A., \& El-Nafaty, A. (2006). } \\
\text { Pregnancy outcomes of women with eclampsia } \\
\text { in Gombe, Nigeria. International Journal of } \\
\text { Gynecology and Obstetrics, 92(3), 251-252. }\end{array}$ & $\begin{array}{l}\text { Review of } \\
\text { hospital } \\
\text { records }\end{array}$ & $\begin{array}{l}\text { Specialist Hospital Gombe } \\
\text { January } 1,1997- \\
\text { December } 31,2000 \\
11,985 \text { deliveries }\end{array}$ & $\begin{array}{l}\text { Incidence of } \\
\text { eclampsia: } \\
3.7 \%\end{array}$ & $\begin{array}{l}\text { - } \quad \text { MMR } 2058 \text { per } 100,000 \text { deliveries } \\
438 \text { cases of eclampsia, } 67.8 \% \text { were teenage mothers, } 79.8 \% \text { were } \\
\text { primigravidas; } 51.0 \% \text { delivered vaginally } \\
64.7 \% \text { were live births and } 35.3 \% \text { stillbirths. Among women with } \\
\text { eclampsia, perinatal mortality was } 2023 \text { per } 100,000 \text { live births (due } \\
\text { to prematurity, intrauterine fetal death, and low birth weight) }\end{array}$ \\
\hline $\begin{array}{l}\text { Nwagha, U. I., Nwachukwu, D., Dim, C., Ibekwe, } \\
\text { P. C. P., \& Onyebuchi, A. (2010). Maternal } \\
\text { mortality trend in South East Nigeria: less than a } \\
\text { decade to the millennium developmental goals. } \\
\text { Journal of Women's Health (2002), 19(2), 323- } \\
327 .\end{array}$ & $\begin{array}{l}\text { Retrospecti } \\
\text { ve study }\end{array}$ & $\begin{array}{l}\text { Federal Medical Centre } \\
\text { (FMC), Abakiliki and Ebonyi } \\
\text { State University Teaching } \\
\text { Hospital (EBSUTH), } \\
\text { Abakiliki and two mission } \\
\text { hospitals: Mile } 4 \text { Hospital, } \\
\text { Ishieke and Mater }\end{array}$ & & $\begin{array}{l}\text { - } 134 \text { maternal deaths of } 14,884 \text { live births: MMR= 902.7 per } \\
\text { 100,000 live births } \\
\text { - } 30 \% \text { of all deaths were 20-29 years old and } 35.1 \% \text { were grand } \\
\text { multiparous; overall } 12 \text { maternal deaths }(12.4 \%) \text { from PE/E } \\
\text { - } \quad \text { Most common cause of death at FMC was PE/E (30\%)(n=3) } \\
\text { EBSUTH saw } 2(6.5 \%) \text { maternal deaths from PE/E, Mile } 4 \text { Hospital had } \\
2(7.7 \%) \text { and Mater Misericordiae Hospital had } 5(16.7 \%) \text { maternal } \\
\text { deaths from PE/E }\end{array}$ \\
\hline
\end{tabular}




\begin{tabular}{|c|c|c|c|c|}
\hline Citation & $\begin{array}{l}\text { Study } \\
\text { Design }\end{array}$ & $\begin{array}{l}\text { Location, Timeframe, and } \\
\text { Sample size }\end{array}$ & $\begin{array}{l}\text { Prevalence/ } \\
\text { Incidence/ } \\
\text { CFR }\end{array}$ & $\begin{array}{l}\text { Main findings/ limitations } \\
\text { Conclusions/ } \\
\text { Recommendations= }\end{array}$ \\
\hline & & $\begin{array}{l}\text { Misericordiae Hospital, } \\
\text { Afikpo } \\
\text { January 2003-December } \\
2005 \\
\text { 14,884 live births }\end{array}$ & & \\
\hline $\begin{array}{l}\text { Nwobodo, E., \& Ahmed, Y. (2011). Maternal } \\
\text { mortality associated with eclampsia in Sokoto, } \\
\text { Nigeria. Orient Journal of Medicine2, } 23 .\end{array}$ & $\begin{array}{l}\text { Retrospecti } \\
\text { ve hospital } \\
\text { record } \\
\text { review }\end{array}$ & $\begin{array}{l}\text { Usmanu Danfodiyo } \\
\text { University Teaching } \\
\text { Hospital, Sokoto } \\
\text { January 2005-December } \\
2009 . \\
277 \text { maternal deaths }\end{array}$ & CFR: $31.7 \%$ & $\begin{array}{l}\text { - } 117(42.2 \%) \text { of maternal deaths were caused by eclampsia } \\
\text { CFR was slightly higher for women }<20 \text { years ( } 36.2 \%) \text {, first delivery } \\
\text { (33.8\%), no formal education ( } 32.4 \%) \text { no prenatal care ( } 32.3 \%) \text {, and } \\
\text { Glasgow coma score of }<5 \text { at presentation }(46.1 \%) \text { (only Glasgow } \\
\text { coma score had a significant difference) } \\
\text { 24.7\% of perinatal deaths were due to eclampsia ( } 61.5 \% \text { of which } \\
\text { were from mothers who also died). } \\
\text { Educating women, promoting FP, ANC and delivery services, and } \\
\text { health education on feature of severe PE are measures that can help } \\
\text { reduce maternal death from eclampsia }\end{array}$ \\
\hline $\begin{array}{l}\text { Okafor, U. V, \& Aniebue, U. (2004). Admission } \\
\text { pattern and outcome in critical care obstetric } \\
\text { patients. International Journal of Obstetric } \\
\text { Anesthesia, 13(3), 164-166. }\end{array}$ & $\begin{array}{l}\text { Retrospecti } \\
\text { ve review } \\
\text { of hospital } \\
\text { records }\end{array}$ & $\begin{array}{l}\text { University of Nigeria } \\
\text { Teaching Hospital, Enugu. } \\
\text { January 1997-December } \\
2002 \\
6,544 \text { deliveries }\end{array}$ & & $\begin{array}{l}\text { - } 816 \text { patients admitted to ICU during period, rate of } 2.8 \text { per } 1000 \\
\text { deliveries. } \\
\text { Nine were preeclamptic or eclamptic (which made up } 50 \% \text { of the } \\
\text { obstetric admissions) other obstetric admissions included: obstetric } \\
\text { haemorrhage, gestational diabetes. } \\
\text { - Four of the PE/E cases admitted to the ICU died }(44 \%) \text { due to } \\
\text { cardiovascular collapse following multiple organ failure }(n=3) \text { and } \\
\text { cerebral haemorrhage ( } n=1) \text {. } \\
\text { This and other studies show that PE/E and obstetric haemorrhage are } \\
\text { the most common causes of obstetric admissions to the ICU } \\
\text { This study suggests that PE/E might benefit from preoperative } \\
\text { admission to ICU and invasive monitoring could help reduce mortality }\end{array}$ \\
\hline $\begin{array}{l}\text { Okafor, U. V, \& Efetie, R. E. (2008). Critical care } \\
\text { management of eclamptics: Challenges in an } \\
\text { African setting. Tropical Doctor, 38(1), 11-13. }\end{array}$ & $\begin{array}{l}\text { Retrospecti } \\
\text { ve study of } \\
\text { records }\end{array}$ & $\begin{array}{l}\text { ICU of the National } \\
\text { Hospital, Abuja } \\
\text { November 2001-April } \\
2005\end{array}$ & CFR: $29 \%$ & $\begin{array}{l}\text { - } 40 \text { eclamptics presented at the ICU during the study period, but } \\
\text { records for two were incomplete and not included in analysis; ICU } \\
\text { admission rate of } 8.2 \text { per } 1000 \text { live births. } 32 \text { ( } 84.2 \%) \text { of these } \\
\text { patients were unbooked for ANC. } \\
4,857 \text { deliveries, } 4,854 \text { live births, (5,051 total births, including } \\
\text { multiple births). } \\
\text { - } 20(52.6 \%) \text { had antepartum eclampsia, } 12(31.6 \%) \text { had postpartum } \\
\text { eclampsia, and six (15.8\%) had intrapartum eclampsia } \\
29(76.3 \%) \text { were delivered by caesarian section } \\
\text { - } \quad \text { Major complications included: HELLP syndrome, disseminated } \\
\text { intravascular coagulation, acute renal failure, and quadriplegia. } \\
\text { MgSO4 was unavailable at the time, ant all expect for one of the } \\
\text { patients received diazepam to control fitting. }\end{array}$ \\
\hline
\end{tabular}




\begin{tabular}{|c|c|c|c|c|}
\hline Citation & $\begin{array}{l}\text { Study } \\
\text { Design }\end{array}$ & $\begin{array}{l}\text { Location, Timeframe, and } \\
\text { Sample size }\end{array}$ & $\begin{array}{l}\text { Prevalence/ } \\
\text { Incidence/ } \\
\text { CFR }\end{array}$ & $\begin{array}{l}\text { Main findings/ limitations } \\
\text { Conclusions/ } \\
\text { Recommendations= }\end{array}$ \\
\hline & & & & $\begin{array}{l}\text { To lower BP, Hydrallazine was the preferred antihypertensive. } \\
\text { - The main cause of death in this study was HELLP syndrome ( } n=5 \text {, } \\
45 \%)\end{array}$ \\
\hline $\begin{array}{l}\text { Okeh, U. (2009). Statistical analysis of the } \\
\text { maternal death rate at the Ebonyi State } \\
\text { University Teaching Hospital, Abakaliki, for the } \\
\text { year ending } 31 \text { December 2007. African Journal } \\
\text { of Primary Health Care and Family Medicine, } \\
\text { 1(1), } 3 \text { p. }\end{array}$ & $\begin{array}{l}\text { Retrospecti } \\
\text { ve review } \\
\text { of case } \\
\text { notes }\end{array}$ & $\begin{array}{l}\text { Ebonyi State University } \\
\text { Teaching Hospital, } \\
\text { Abakaliki } \\
\text { January 1-December 31, } \\
2007 \\
1,646 \text { deliveries }\end{array}$ & & $\begin{array}{l}\text { - } \quad \text { MMR }=2735.6 \text { per } 100,000 \text { deliveries } \\
\text { Severe PE/E accounted for } 35.6(n=16) \text { maternal deaths } \\
\text { (haemorrhage caused } 28.9 \% \text { and sepsis caused } 13.3 \% \text { of maternal } \\
\text { deaths) } \\
88.9 \%(n=40) \text { of all maternal deaths were unbooked; improving ANC } \\
\text { attendance an help prevent development of severe PE/E and reduce } \\
\text { maternal death by detecting and managing pre-eclampsia early }\end{array}$ \\
\hline $\begin{array}{l}\text { Okogbenin, S A et al. "Eclampsia in Irrua } \\
\text { Specialist Teaching Hospital: A Five-Year } \\
\text { Review." Nigerian Journal of Clinical Practice } \\
\text { 13.2 (2010): } 149-153 .\end{array}$ & $\begin{array}{l}\text { Retrospecti } \\
\text { ve review }\end{array}$ & $\begin{array}{l}\text { Irrua Specialist Teaching } \\
\text { Hospital, Edo state } \\
5 \text { year period } \\
78 \text { cases of eclampsia }\end{array}$ & & 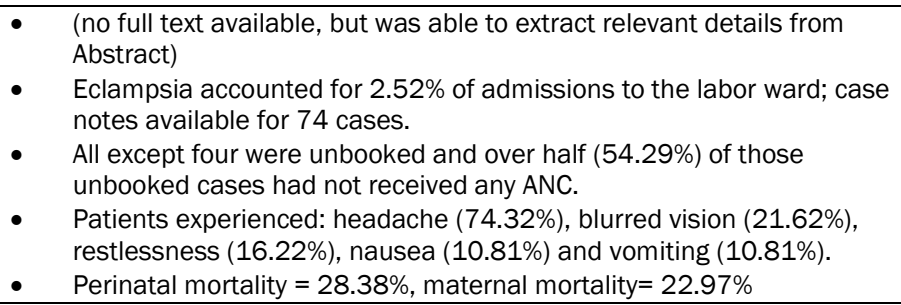 \\
\hline $\begin{array}{l}\text { Okusanya, BO et al. "Maternal Deaths: Initial } \\
\text { Report of an on-Going Monitoring of Maternal } \\
\text { Deaths at the Federal Medical Centre Katsina, } \\
\text { Northwest Nigeria." Journal of Maternal - Fetal } \\
\text { and Neonatal Medicine } 26.9 \text { (2013): 885-888. }\end{array}$ & $\begin{array}{l}\text { Review of } \\
\text { hospital } \\
\text { reports on } \\
\text { maternal } \\
\text { death }\end{array}$ & $\begin{array}{l}\text { Department of Obstetrics } \\
\text { and Gynaecology, College } \\
\text { of Medicine, University of } \\
\text { Lagos } \\
\text { June 1, 2008-May 31, } \\
2012 \\
68 \text { maternal deaths }\end{array}$ & & $\begin{array}{l}\text { - } \mathrm{MMR}=827 \text { per } 100,000 \text { live births, } \mathrm{PE} / \mathrm{E} \text { was the second most } \\
\text { common direct cause of maternal death }(\mathrm{n}=14,18.9 \%) \\
\text { - } \quad \text { mong teenagers ( } 23.5 \% \text { of deliveries), } \mathrm{PE} / \mathrm{E} \text { was the most common } \\
\text { cause of maternal death, accounting for } 37.5 \%\end{array}$ \\
\hline $\begin{array}{l}\text { Oladapo O, Adetoro O, Ekele B, Chama C, Etuk } \\
\text { S, Aboyeji A, et al. When getting there is not } \\
\text { enough: a nationwide cross-sectional study of } \\
998 \text { maternal deaths and } 1451 \text { near-misses in } \\
\text { public tertiary hospitals in a low-income country. } \\
\text { BJOG An Int J Obstet Gynaecol [Internet]. } 2015\end{array}$ & $\begin{array}{l}\text { Prospectiv } \\
\text { e review of } \\
\text { hospital } \\
\text { cases } \\
\text { Cross } \\
\text { sectional }\end{array}$ & $\begin{array}{l}\text { Nigeria } \\
\text { June 1, 2012-August } 14, \\
2013 \\
42 \text { hospitals in six } \\
\text { geopolitical zones } \\
2,449 \text { SMO cases }\end{array}$ & & $\begin{array}{l}\text { - Identified all cases of severe maternal outcome (SMO): maternal near- } \\
\text { miss (1451) or maternal death (998). } \\
\text { - } 101,724 \text { live births, MMR at participating facilities was } 1088 \text { per } \\
\text { 100,000 live births, maternal near-miss was } 15.8 \text { per } 1,000 \text { live } \\
\text { births, and SMO ratio was } 26.7 \text { per } 1,000 \text { live births. } \\
\text { - Hypertensive disorders (chronic hypertension and PE/E) were the } \\
\text { most common complication and caused } 24 \% \text { of SMOs } \\
\text { Eclampsia was the most frequent complication and accounted for } 1 / 5 \\
\text { maternal deaths. } \\
\text { About half women experiencing organ dysfunction due to hypertensive } \\
\text { disorders in pregnancy, died-effort is needed to reduce maternal } \\
\text { mortality by promptly managing organ dysfunction resulting from HDP. } \\
\text { Overall, the median time interval to initiating “definitive } \\
\text { treatment/intervention' was } 60 \text { minutes, but in } 47.4 \% \text { of SMO cases, }\end{array}$ \\
\hline
\end{tabular}




\begin{tabular}{|c|c|c|c|c|}
\hline Citation & $\begin{array}{l}\text { Study } \\
\text { Design }\end{array}$ & $\begin{array}{l}\text { Location, Timeframe, and } \\
\text { Sample size }\end{array}$ & $\begin{array}{l}\text { Prevalence/ } \\
\text { Incidence/ } \\
\text { CFR }\end{array}$ & $\begin{array}{l}\text { Main findings/ limitations } \\
\text { Conclusions/ } \\
\text { Recommendations= }\end{array}$ \\
\hline & & & & $\begin{array}{l}\text { the delay was over an hour and in more than } 1 / 5 \text { cases it was over } \\
\text { four hours } \\
\text { The research team identified deficiencies in management of almost } \\
\text { half SMO cases (1215, 49.6\%) } \\
\text { Contributors to substandard care included: late presentation to } \\
\text { hospital, inability to pay/no insurance, unavailability of blood products }\end{array}$ \\
\hline $\begin{array}{l}\text { Oladapo, O., Lamina, M., \& Fakoya, T. (2006). } \\
\text { Maternal deaths in Sagamu in the new } \\
\text { millennium: a facility-based retrospective } \\
\text { analysis. BMC Pregnancy and Childbirth, } 6,6 .\end{array}$ & $\begin{array}{l}\text { Retrospecti } \\
\text { ve } \\
\text { descriptive } \\
\text { analysis }\end{array}$ & $\begin{array}{l}\text { Olabisi Onabanjo University } \\
\text { Teaching Hospital, } \\
\text { Sagamu, Nigeria } \\
\text { January } 1 \text {, 2000-June } 30 \\
2005 \\
75 \text { maternal deaths }\end{array}$ & N/A & $\begin{array}{l}\text { - } 75 \text { maternal deaths and } 2509 \text { live births; } M M R=2989.2 \text { per } 100,000 \\
\text { live births } \\
\text { - Hypertensive disorders in pregnancy (severe PE/E) caused } 28 \% \text { of the } \\
\text { maternal deaths, (eclampsia: } 24 \% \text {, severe PE, } 4 \% \text { ) } \\
\text { Nine women died from complications due to severe PE/E before } \\
\text { delivery; these complications were: cerebrovascular accident }(n=8) \\
\text { and acute renal failure }(n=1) \text {. } \\
\text { Up to the end of the study period, MgSO4 had not been adopted for } \\
\text { treating severe PE/E and was unavailable }\end{array}$ \\
\hline $\begin{array}{l}\text { Olapade, F., \& Lawoyin, T. (2008). Maternal } \\
\text { mortality in a Nigerian maternity hospital. African } \\
\text { Journal of Biomedical Research, 11(3), } 267- \\
273 .\end{array}$ & $\begin{array}{l}\text { Retrospecti } \\
\text { ve case } \\
\text { control }\end{array}$ & $\begin{array}{l}\text { Adeoyo Maternity Hospital, } \\
\text { Ibadan, } \\
\text { January 2003-December } \\
2004 \\
84 \text { maternal deaths }\end{array}$ & & $\begin{array}{l}\text { - } \quad \text { MMR }=963 \text { per } 100,000 \text { live births } \\
14(16.7 \%) \text { maternal deaths caused by eclampsia; } 64.2 \% \text { of these } \\
\text { were among women under } 25 \text { years old } \\
71.4 \% \text { of deaths due to eclampsia were in nulliparous women, } 85 \% \\
\text { occurred within } 24 \text { hours of being admitted, } 71.4 \% \text { were unbooked, } \\
\text { and more deaths due to eclampsia were seen during the rainy season }\end{array}$ \\
\hline $\begin{array}{l}\text { Olatunji, A. O., \& Sule Odu, A. O. (2006). } \\
\text { Maternal mortality from eclampsia. Journal of } \\
\text { Obstetrics and Gynaecology, 26(6), 542-543. }\end{array}$ & $\begin{array}{l}\text { Retrospecti } \\
\text { ve review }\end{array}$ & $\begin{array}{l}\text { Olabisi Onabanjo University } \\
\text { Teaching Hospital, Sagamu } \\
1988-1997 \\
93 \text { cases of eclampsia }\end{array}$ & $\begin{array}{l}\text { Incidence } \\
1.7 \% \\
\text { CF ratio: } 0.2 \\
\text { (20\%, CFR) }\end{array}$ & $\begin{array}{l}\text { - } \quad \text {,423 deliveries over the study period and } 92 \text { maternal deaths, } 19 \text { of } \\
\text { which were caused by eclampsia. } \\
82 \text { cases were antepartum, eight were intrapartum and three were } \\
\text { postpartum, } 94.7 \% \text { of deaths were in antepartum cases. }\end{array}$ \\
\hline $\begin{array}{l}\text { Olatunji, A., \& Sule-Odu, A. (2007). Presentation } \\
\text { and outcome of eclampsia at a Nigerian } \\
\text { University Hospital. Nigerian Journal of Clinical } \\
\text { Practice. }\end{array}$ & $\begin{array}{l}\text { Retrospecti } \\
\text { ve review }\end{array}$ & $\begin{array}{l}\text { Olabisi Onabanjo University } \\
\text { Teaching Hospital, Sagamu } \\
\text { January 1988-December } \\
1997 \\
93 \text { cases of eclampsia }\end{array}$ & $\begin{array}{l}\text { Incidence } \\
1.7 \% \\
\text { CFR: } 20.4 \%\end{array}$ & $\begin{array}{l}\text { - } 93 \text { cases of eclampsia, all patients received diazepam to control } \\
\text { convulsions and hydralazine (antihypertensive) when needed. } \\
\text { 96.8\% were unbooked, } 60.2 \% \text { were delivered by caesarean section, } \\
\text { and } 78.5 \% \text { were nulliparous } \\
\text { Nulliparous teenagers were the most at risk of dying from eclampsia } \\
\text { - } \quad 38 \text { ) } \\
\text { (* were antepartum, } 4 \text { were intrapartum and } 2 \text { were postpartum } \\
\text { (*conflicts with previous paper published on these data, above) }\end{array}$ \\
\hline $\begin{array}{l}\text { Olowonyo, T., Oshin, S., \& Obasanjo-Bello, I. } \\
\text { (2005). Registering in a health facility for } \\
\text { delivery protects against maternal mortality in a } \\
\text { developing country setting. Journal of Obstetrics }\end{array}$ & $\begin{array}{l}\text { Prospectiv } \\
\text { e cross- } \\
\text { sectional } \\
\text { study }\end{array}$ & $\begin{array}{l}\text { Primary, secondary and } \\
\text { tertiary facilities and } 123 \\
\text { private facilities in Ogun } \\
\text { State }\end{array}$ & N/A & $\begin{array}{l}\text { - Using a one-page form, researchers collected the data elements they } \\
\text { required to calculate various neonatal, perinatal, infant, under-five } \\
\text { and maternal mortality rates. } \\
\text { - } \quad \text { MMR }=177.6 \text { per } 100,000 \text { live births } \\
\text { - Eclampsia accounted for } 9 \text { of the } 37 \text { maternal deaths }\end{array}$ \\
\hline
\end{tabular}




\begin{tabular}{|c|c|c|c|c|}
\hline Citation & $\begin{array}{l}\text { Study } \\
\text { Design }\end{array}$ & $\begin{array}{l}\text { Location, Timeframe, and } \\
\text { Sample size }\end{array}$ & $\begin{array}{l}\text { Prevalence/ } \\
\text { Incidence/ } \\
\text { CFR }\end{array}$ & $\begin{array}{l}\text { Main findings/ limitations } \\
\text { Conclusions/ } \\
\text { Recommendations= }\end{array}$ \\
\hline and Gynaecology, 25(7), 638-641. & & $\begin{array}{l}\text { November 2003-July } \\
2004 \\
37 \text { maternal deaths }\end{array}$ & & $\begin{array}{l}\text { - } 8 \text { of the } 9 \text { deaths caused by eclampsia were unbooked/unregistered } \\
\text { patients }\end{array}$ \\
\hline $\begin{array}{l}\text { Omo-Aghoja, L., Aisien, O., Akuse, J., \& } \\
\text { Okonofua, F. (2010). Maternal mortality and } \\
\text { emergency obstetric care in Benin City South- } \\
\text { south Nigeria. Journal of Clinical Medicine and } \\
\text { Research, 2(4), 55-60. }\end{array}$ & $\begin{array}{l}\text { Retrospecti } \\
\text { ve review } \\
\text { of hospital } \\
\text { records }\end{array}$ & $\begin{array}{l}\text { University of Benin } \\
\text { Teaching Hospital, Benin } \\
\text { City, Edo state } \\
\text { January 1, 2005- } \\
\text { December 31, 2007 } \\
\text { 3,681 deliveries }\end{array}$ & CFR: $15.9 \%$ & $\begin{array}{l}\text { - } 84 \text { maternal deaths, MMR }=2,282 \text { per } 100,000 \text { deliveries, } \\
\text { - } 113 \text { cases of eclampsia were managed } \\
\text { - } 18(21.4 \%)(* \text { there was a typo in the table, it says } 12.4 \%) \text { of the } \\
\text { maternal deaths were due to "severe pregnancy induced } \\
\text { hypertension/eclampsia" } \\
\text { - Recommends improved emergency obstetric services }\end{array}$ \\
\hline $\begin{array}{l}\text { Onah, H., Okaro, J., Umeh, U., \& Chigbu, C. } \\
\text { (2005). Maternal mortality in health institutions } \\
\text { with emergency obstetric care facilities in Enugu } \\
\text { State, Nigeria. Journal of Obstetrics and } \\
\text { Gynaecology, 25(6), 569-574. }\end{array}$ & $\begin{array}{l}\text { Retrospecti } \\
\text { ve } \\
\text { maternal } \\
\text { death } \\
\text { analysis }\end{array}$ & $\begin{array}{l}\text { Enugu State } \\
\text { December 1, 2003-April } \\
\text { 30, } 2004 \\
141 \text { maternal deaths }\end{array}$ & & 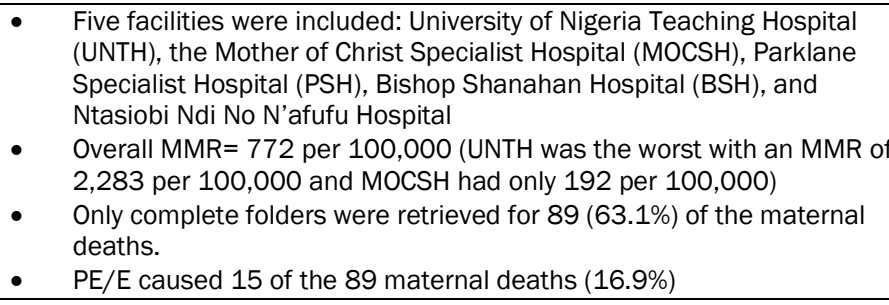 \\
\hline $\begin{array}{l}\text { Onakewhor, J. U. E., \& Gharoro, E. P. (2008). } \\
\text { Changing trends in maternal mortality in a } \\
\text { developing country. Nigerian Journal of Clinical } \\
\text { Practice, 11(2), 111-120. }\end{array}$ & $\begin{array}{l}\text { Retropectiv } \\
\text { e review of } \\
\text { case notes }\end{array}$ & $\begin{array}{l}\text { Mission hospital, Benin City } \\
\text { January 1, 1996- } \\
\text { December 31, } 2000 \\
32 \text { maternal deaths }\end{array}$ & $\mathrm{N} / \mathrm{A}$ & $\begin{array}{l}\text { - 32deaths out of 7,055 deliveries, MMR= } 454 \text { per } 100,000 \\
\text { - } 34.4 \% \text { ( } n=11 \text { ) of maternal deaths were due to eclampsia; this was the } \\
\text { most significant cause of maternal death followed by sepsis and PPH } \\
\text { at } 18.8 \% \text { each } \\
\text { This study presents some case scenarios of maternal deaths, two } \\
\text { related to PE/E: } \\
\text { - -One woman, } 32 \text { years old, para 2, with PE arrived at the UBTH after } \\
\text { being referred from a private maternity home, after two convulsions, } \\
\text { she died before she could deliver } \\
\text {--A } 25 \text { year old woman with severe PE (BP 181/130mmHg) declined } \\
\text { admission, went home to update her husband and returned later but } \\
\text { died shortly after re-admission }\end{array}$ \\
\hline $\begin{array}{l}\text { Onwuhafua, P. I. (2002). Dying undelivered. } \\
\text { Journal of Obstetrics and Gynaecology: The } \\
\text { Journal of the Institute of Obstetrics and } \\
\text { Gynaecology, 22(2), 155-158. }\end{array}$ & $\begin{array}{l}\text { Retrospecti } \\
\text { ve review } \\
\text { of hospital } \\
\text { records }\end{array}$ & $\begin{array}{l}\text { Ahmadu Bello University } \\
\text { Teaching Hospital, Kaduna } \\
\text { January 1, 1990_- } \\
\text { December 31, } 1997 \\
15 \text { women who died } \\
\text { undelivered }\end{array}$ & & $\begin{array}{l}\text { - } 53 \text { maternal deaths out of 10,572 deliveries; MMR= } 501 \text { per } \\
100,000 \\
\text { - } \quad \text { Incidence of dying undelivered = } 141 \text { per } 100,000 \text { deliveries } \\
\text { - Severe PE/E contributed six (40\%) of the undelivered deaths, followed } \\
\text { by ruptured uterus ( } n=4,26.7 \%) \\
\text { - Two of the eclampsia patients were grandmultiparae, poor, and } \\
\text { illiterate. } \\
\text { - Seven of the fetuses survived and six of them were in patients with } \\
\text { eclampsia. }\end{array}$ \\
\hline
\end{tabular}




\begin{tabular}{|c|c|c|c|c|}
\hline Citation & $\begin{array}{l}\text { Study } \\
\text { Design }\end{array}$ & $\begin{array}{l}\text { Location, Timeframe, and } \\
\text { Sample size }\end{array}$ & $\begin{array}{l}\text { Prevalence/ } \\
\text { Incidence/ } \\
\text { CFR }\end{array}$ & $\begin{array}{l}\text { Main findings/ limitations } \\
\text { Conclusions/ } \\
\text { Recommendations= }\end{array}$ \\
\hline & & & & $\begin{array}{l}\text { Recommendations include: health education for would-be clients, } \\
\text { improve content of ANC, improve obstetric emergency capability at } \\
\text { facility, establish materno-fetal medicine unit and awareness and } \\
\text { policy relating to postmortem caesarean section }\end{array}$ \\
\hline $\begin{array}{l}\text { Onwuhafua, P. I., Onwuhafua, A., \& Adze, J. } \\
\text { (2000). The challenge of reducing maternal } \\
\text { mortality in Nigeria. INTERNATIONAL JOURNAL } \\
\text { OF GYNECOLOGY \& OBSTETRICS, 71(3), 211- } \\
213 .\end{array}$ & $\begin{array}{l}\text { Retrospecti } \\
\text { ve review } \\
\text { of hospital } \\
\text { records }\end{array}$ & $\begin{array}{l}\text { Ahmadu Bello University } \\
\text { Teaching Hospital, Kaduna } \\
\text { 1990-1997 } \\
53 \text { obstetric deaths } \\
16 \text { abortion deaths }\end{array}$ & & $\begin{array}{ll}\text { - } & \text { MMR }=652 \text { per } 100,000 \text { (including abortion deaths) } \\
\text { - } & \text { Nulliparity and unbooked had the highest rates of maternal mortality. } \\
\text { - } & \text { Eclampsia contributed } 17 \text { maternal deaths }(36.95 \%)\end{array}$ \\
\hline $\begin{array}{l}\text { Onwuhafua, P. I., Onwuhafua, A., Adze, J., \& } \\
\text { Mairami, Z. (2001). Eclampsia in Kaduna State } \\
\text { of Nigeria--a proposal for a better outcome. } \\
\text { Nigerian Journal of Medicine : Journal of the } \\
\text { National Association of Resident Doctors of } \\
\text { Nigeria, 10(2), 81-84. }\end{array}$ & $\begin{array}{l}\text { Retrospecti } \\
\text { ve review } \\
\text { of hospital } \\
\text { records }\end{array}$ & $\begin{array}{l}\text { Ahmadu Bello University } \\
\text { Teaching Hospital, Kaduna } \\
\text { 1990-1997 } \\
45 \text { cases of eclampsia }\end{array}$ & $\begin{array}{l}\text { Incidence of } \\
\text { eclampsia= } \\
0.42 \% \\
\text { CFR: } \\
42.22 \%\end{array}$ & $\begin{array}{l}\text { - } \quad \text { Antepartum eclampsia occurred in } 60 \% \text { of cases, } 31.3 \% \text { had } \\
\text { intrapartum and } 8.7 \% \text { postpartum } \\
\text { The most common symptoms were: headache (100\%), hypertension } \\
\text { (88.88\%) and fever }(42.22 \%) \text {. } \\
\text { - } \quad \text { Diazepam successfully controlled fits in } 66.6 \% \text { of patients } \\
\text { - } \quad \text { Recommentaternal and } 20 \text { perinatal deaths } \\
\text { and distributed as guides to all hospitals, ANC and delivery services } \\
\text { must improve and provide quality surveillance of women and } \\
\text { identification of women at risk of eclampsia, intensive care facilities } \\
\text { are needed to treat women experiencing acute renal and } \\
\text { cardiopulmonary complications. }\end{array}$ \\
\hline $\begin{array}{l}\text { Orji, E., Ogunlola, I., \& Onwudiegwu, U. (2002). } \\
\text { Brought-in maternal deaths in south-west } \\
\text { Nigeria. Journal of Obstetrics and Gynaecology, } \\
22(4), 385-388 .\end{array}$ & $\begin{array}{l}\text { Prospectiv } \\
\text { e review at } \\
\text { hospital }\end{array}$ & $\begin{array}{l}\text { Ife State Hospital, lle-lfe } \\
\text { and Wesley Guild Hospital, } \\
\text { llesa (part of the Obafemi } \\
\text { Awolowo University } \\
\text { Teaching Hospitals } \\
\text { Complex) } \\
\text { 1995-1999 } \\
24 \text { brought-in maternal } \\
\text { deaths }\end{array}$ & & $\begin{array}{l}\text { Eclampsia was determined to be the probable cause of death in } 8 \\
\text { (33.3\%) of the brought-in maternal deaths } \\
\text { - Common reasons for late presentation to the hospital include: inability } \\
\text { to obtain transit ( } 41.7 \% \text { ), inability of health care staff to detect } \\
\text { problems early enough (33.3\%), inability of referring hospital to } \\
\text { perform emergency C-section ( } 25 \% \text { ), unavailability of blood for } \\
\text { transfusion( } 25 \%) \text {, unwillingness of drivers to travel at night (25\%), } \\
\text { and no money to pay for hospital fees ( } 16.7 \%) \\
\text { One woman had suffered from eclampsia at } 38 \text { weeks gestation and it } \\
\text { took her husband some time to collect the money for transit and } \\
\text { hospital fees. She was carried on a motorcycle for } 10 \mathrm{~km} \text { to the closest } \\
\text { place to get on a vehicle to the facility. She had to wait for the vehicle } \\
\text { to arrive and died on the way before arriving at the hospital. }\end{array}$ \\
\hline $\begin{array}{l}\text { Sule-Odu, A. (2000). Maternal deaths in } \\
\text { Sagamu, Nigeria. International Journal of } \\
\text { Gynecology and Obstetrics, 69(1), 47-49. }\end{array}$ & $\begin{array}{l}\text { Review of } \\
\text { hospital } \\
\text { records }\end{array}$ & $\begin{array}{l}\text { Ogun State University } \\
\text { Teaching Hospital, Sagamu } \\
\text { 1988-1997 }\end{array}$ & & $\begin{array}{l}\text { - } \mathrm{MMR}=1936.1 \text { per } 100,000=103 \text { maternal deaths out of } 5320 \\
\text { deliveries, } 86.4 \% \text { of which were due to obstetric causes } \\
\text { - } \quad \text { Eclampsia accounted for } 13(12.6 \%) \text { of all maternal deaths and } \\
\text { pregnancy induced hypertension caused } 5(4.9 \%) \\
\text { Blood banking, improved access to healthcare services and } \\
\text { empowering women can reduce maternal deaths. }\end{array}$ \\
\hline
\end{tabular}




\begin{tabular}{|c|c|c|c|c|}
\hline Citation & $\begin{array}{l}\text { Study } \\
\text { Design }\end{array}$ & $\begin{array}{l}\text { Location, Timeframe, and } \\
\text { Sample size }\end{array}$ & $\begin{array}{l}\text { Prevalence/ } \\
\text { Incidence/ } \\
\text { CFR }\end{array}$ & $\begin{array}{l}\text { Main findings/ limitations } \\
\text { Conclusions/ } \\
\text { Recommendations= }\end{array}$ \\
\hline & & 103 maternal deaths & & \\
\hline $\begin{array}{l}\text { Tukur, J., Umar, B. A., \& Rabi'u, A. (2007). } \\
\text { Pattern of eclampsia in a tertiary health facility } \\
\text { situated in a semi-rural town in northern Nigeria. } \\
\text { Annals of African Medicine, 6(4), 164-167. }\end{array}$ & $\begin{array}{l}\text { Retrospecti } \\
\text { ve review } \\
\text { of case } \\
\text { records }\end{array}$ & $\begin{array}{l}\text { Federal Medical Centre, } \\
\text { Birnin Kudu, Jigawa State } \\
207 \text { cases of eclampsia }\end{array}$ & $\begin{array}{l}\text { Incidence of } \\
\text { eclampsia: } \\
9.42 \%\end{array}$ & $\begin{array}{l}\text { - } \quad \text { Eclampsia contributed to } 43.1 \% \text { ( } n=22 \text { ) of all maternal deaths and } 27 \\
\text { (13\%) perinatal deaths } \\
\text { - } \quad 56 \% \text { of patients experienced delay before reaching hospital. } \\
58.5 \% \text { were }<20 \text { years old, } 78.3 \% \text { were primigravida, and } 51.7 \% \text { were } \\
\text { delivered by cesarean section } \\
\text { - Eclampsia manifested antepartum in } 32.9 \% \text { ( } n=69 \text { ), intrapartum in } \\
54.1 \% \text { ( } n=112 \text { ) and postpartum in } 12 \%(27) \text {. } \\
\text { - Recommends health education for community members to increase } \\
\text { awareness of the importance of ANC }\end{array}$ \\
\hline $\begin{array}{l}\text { Ujah, I. A. O., Aisien, O. A., Mutihir, J. T., } \\
\text { Vanderjagt, D. J., Glew, R. H., \& Uguru, V. E. } \\
\text { (2005). Maternal mortality among adolescent } \\
\text { women in Jos, north-central, Nigeria. Journal of } \\
\text { Obstetrics and Gynaecology, 25(1), 3-6. }\end{array}$ & $\begin{array}{l}\text { Retrospecti } \\
\text { ve case file } \\
\text { review }\end{array}$ & $\begin{array}{l}\text { Jos University Teaching } \\
\text { Hospital, Jos, Plateau State } \\
\text { January 1991-December } \\
2001 \\
4,564 \text { adolescent } \\
\text { deliveries }\end{array}$ & N/A & $\begin{array}{l}\text { - } \quad \text { Adolescent }=10-19 \text { years old } \\
25 \text { maternal deaths among study population, Adolescent MMR= } 547 \\
\text { per } 100,000 \text { deliveries } \\
\text { Eclampsia and Sepsis each caused } 5 \text { deaths, accounting for } 26.3 \% \\
\text { each of the overall adolescent maternal deaths. }\end{array}$ \\
\hline $\begin{array}{l}\text { Ujah, I., Aisien, O., Mutihir, J., Vanderjagt, D., } \\
\text { Glew, R., \& Uguru, V. (2005). Factors } \\
\text { contributing to maternal mortality in north- } \\
\text { central Nigeria: a seventeen-year review. African } \\
\text { Journal of Reproductive Health, } 9(3), 27-40 .\end{array}$ & $\begin{array}{l}\text { Review of } \\
\text { case files }\end{array}$ & $\begin{array}{l}\text { Jos University Teaching } \\
\text { Hospital, Jos, Plateau State } \\
\text { 1985-2001 } \\
267 \text { maternal deaths }\end{array}$ & & $\begin{array}{l}\text { - } 267 \text { maternal deaths out of 38,768: MMR } 740 \text { per } 100,000 \\
\text { deliveries } \\
\text { Eclampsia accounted for } 75 \text { (23.6\%) of all maternal deaths. } \\
\text { Eclampsia ranked third most common direct cause of maternal death } \\
\text { after Haemorrhage (34.6\%) and sepsis (28.3\%) } \\
\text { - An indirect cause of maternal mortality was acute renal failure }(8 \%) \\
\text { which is a complication of eclampsia. }\end{array}$ \\
\hline $\begin{array}{l}\text { Yakasai, I., \& Gaya, S. (2011). Maternal and } \\
\text { fetal outcome in patients with eclampsia at } \\
\text { Murtala Muhammad specialist Hospital Kano, } \\
\text { Nigeria. Annals of African Medicine. }\end{array}$ & $\begin{array}{l}\text { Case } \\
\text { record } \\
\text { review }\end{array}$ & $\begin{array}{l}\text { Murtala Muhammad } \\
\text { Specialist Hospital (MMSH) } \\
\text { Kano } \\
\text { April 2008-May } 2009 \\
688 \text { cases of eclampsia }\end{array}$ & $\begin{array}{l}\text { Prevalence } \\
\text { of } \\
\text { eclampsia: } \\
5 \% \\
\text { CFR }=5.2 \%\end{array}$ & $\begin{array}{ll} & 127 \text { women died out of } 13,943 \text { deliveries ; MMR= } 904 \text { per } 100,000 \\
& \text { Eclampsia contributed } 28.57 \% \text { of all maternal deaths. } \\
\text { - } & \text { Perinatal mortality among eclamptics was } 132 \text { per } 1000 \text { eclamptic } \\
\text { deliveries. } 6.2 \% \text { were fresh stillbirths, } 3.5 \% \text { were macerated stillbirths, } \\
\text { and 3.5\% were not delivered. } \\
\text { - } \quad 50.14 \% \text { of the patients were teenagers ( } 10-19 \text { years old) } \\
\text { - } 82.3 \% \text { were primigravidae, } 48.5 \% \text { received some ANC (mostly from } \\
\text { primary health centers) } \\
\text { - } 44.9 \% \text { developed convulsions antepartum } \\
\text { - } 83.3 \% \text { presented within } 12 \text { hours of the first convulsion and } \\
\text { outcomes are made worse by delay in presentation. }\end{array}$ \\
\hline
\end{tabular}

